Florida International University FIU Digital Commons

7-9-2014

\title{
Integrated Construction Project Delivery System in the U.S. Public Sector: An Information Modeling Framework
}

Nida Azhar

nazha001@fiu.edu

DOI: $10.25148 /$ etd.FI14071158

Follow this and additional works at: https:// digitalcommons.fiu.edu/etd

Part of the Civil Engineering Commons, and the Construction Engineering and Management Commons

\section{Recommended Citation}

Azhar, Nida, "Integrated Construction Project Delivery System in the U.S. Public Sector: An Information Modeling Framework" (2014). FIU Electronic Theses and Dissertations. 1567.

https://digitalcommons.fiu.edu/etd/1567 


\section{FLORIDA INTERNATIONAL UNIVERSITY}

Miami, Florida

\section{INTEGRATED CONSTRUCTION PROJECT DELIVERY SYSTEM IN THE U.S.}

PUBLIC SECTOR:

\section{AN INFORMATION MODELING FRAMEWORK}

A dissertation submitted in partial fulfillment of

the requirements for the degree of

DOCTOR OF PHILOSOPHY

in

CIVIL ENGINEERING

by

Nida Azhar

2014 
To: Dean Amir Mirmiran

College of Engineering and Computing

This dissertation, written by Nida Azhar, and entitled Integrated Construction Project Delivery System in the U.S. Public Sector: An Information Modeling Framework, having been approved in respect to style and intellectual content, is referred to you for judgment.

We have read this dissertation and recommend that it be approved.

Atorod Azizinamini

Berrin Tansel

Ali Mostafavi

Arindam G. Chowdhury, Co-Major Professor

Irtishad U. Ahmad, Co-Major Professor

Date of Defense: July 9, 2014

The dissertation of Nida Azhar is approved.

Dean Amir Mirmiran
College of Engineering and Computing

Dean Lakshmi N. Reddi University Graduate School

Florida International University, 2014 


\section{DEDICATION}

This dissertation is dedicated to my loving, caring and supportive husband,

Farrukh Arif, our darling sweet little girl, Manha Farrukh, and to my always encouraging, ever faithful parents, Azhar Javaid and Sitara Jabeen. 


\section{ACKNOWLEDGMENTS}

First and foremost I am thankful to Almighty Allah, who in His infinite mercy has guided throughout the course and provided me patience and courage to complete my dissertation.

I would like to thank the members of my dissertation advisory committee, Dr. Atorod Azizinamini, Dr. Berrin Tansel and Dr. Ali Mostafavi for their guidance and support. I would also like to extend my thanks to Dr. Youngcheol Kang who previously served as a member of the committee before leaving Florida International University (FIU), for his intellectual contribution to my research. I would like to express my gratitude to Dr. Arindam G. Chowdhury, my co-major advisor, for his continuous guidance and valuable input throughout my research.

I am thankful to my advisor Dr. Irtishad U. Ahmad for providing me the opportunity to work under his supervision and his incessant support that made it possible for me to complete my dissertation. The experience I have had with Dr. Ahmad over the past four and half years cannot be expressed in a clichéd phrase or saying but I would like to express my deepest appreciations for him for guiding me during the course of my research with such patience. His belief in my research and me has always kept me pushing through the difficulty.

I would like to thank both Department of Civil and Environmental Engineering, and OHL School Construction at Florida International University for giving me the opportunity to pursue doctoral studies. I would also like to thank the faculty members, staff and my fellow students at OHL School of Construction. 
A special note of thanks is due to members of Facilities Management Department (FMD), FIU, who helped me in collecting information for my case studies. Their feedback was valuable in shaping my model. I would specially like to thank Ms. Sylvia Berenguer for her continuous help and support throughout the data collection and model development processes. I would also like to thank the project managers of FMD department for sharing their experiences and insight with me that led me to better understanding of the projects.

I am grateful to NED University of Engineering \& Technology Karachi for providing me the support to peruse my Ph.D. studies. Special thanks to my two mentors Dr. Sarosh H. Lodi and Dr. S.F.A. Rafeeqi for their continuous motivation.

My deepest gratitude and love for my parents Azhar Javaid and Sitara Jabeen for their dedication and support that sustained throughout my studies. I would also thank my siblings Jamshed, Annie and Anita for their unrelenting encouragement. I am thankful to my in-laws for helping in whatever way they could during this challenging period.

I am truly appreciative of my husband for everything he has done for me over the years. I could not have reached my goals without his help and support at all times. I thank him for being a pillar of strength through all my ups and downs.

Finally, a big thank you to my little angel, Manha, for being such a good baby for past eighteen months and making it possible for me to complete what I started. 


\section{ABSTRACT OF THE DISSERTATION \\ INTEGRATED CONSTRUCTION PROJECT DELIVERY SYSTEM IN THE U.S. \\ PUBLIC SECTOR: \\ AN INFORMATION MODELING FRAMEWORK \\ by}

Nida Azhar

Florida International University, 2014

Miami, Florida

Professor Irtishad U. Ahmad, Co-Major Professor

Professor Arindam G. Chowdhury, Co-Major Professor

Integrated project delivery (IPD) method has recently emerged as an alternative to traditional delivery methods. It has the potential to overcome inefficiencies of traditional delivery methods by enhancing collaboration among project participants. Information and communication technology (ICT) facilitates IPD by effective management, processing and communication of information within and among organizations. While the benefits of IPD, and the role of ICT in realizing them, have been generally acknowledged, the US public construction sector is very slow in adopting IPD. The reasons are - lack of experience and inadequate understanding of IPD in public owner as confirmed by the results of the questionnaire survey conducted under this research study. The public construction sector should be aware of the value of IPD and should know the essentials for effective implementation of IPD principles - especially, they should be cognizant of the opportunities offered by advancements in ICT to realize this. 
In order to address the need an IPD Readiness Assessment Model (IPD-RAM) was developed in this research study. The model was designed with a goal to determine IPD readiness of a public owner organization considering selected IPD principles, and ICT levels, at which project functions were carried out. Subsequent analysis led to identification of possible improvements in ICTs that have the potential to increase IPD readiness scores. Termed as the gap identification, this process was used to formulate improvement strategies. The model had been applied to six Florida International University (FIU) construction projects (case studies). The results showed that the IPD readiness of the organization was considerably low and several project functions can be improved by using higher and/or advanced level ICT tools and methods. Feedbacks from a focus group comprised of FIU officials and an independent group of experts had been received at various stages of this research and had been utilized during development and implementation of the model. Focus group input was also helpful for validation of the model and its results. It was hoped that the model developed would be useful to construction owner organizations in order to assess their IPD readiness and to identify appropriate ICT improvement strategies. 
TABLE OF CONTENTS

CHAPTER

PAGE

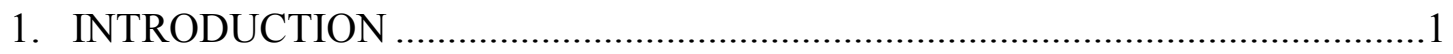

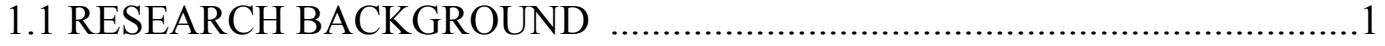

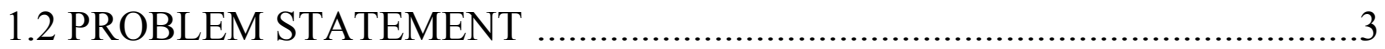

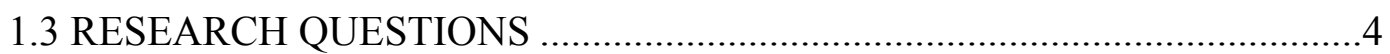

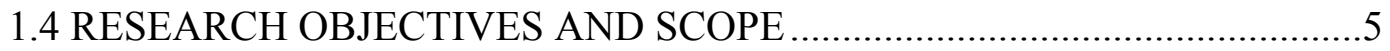

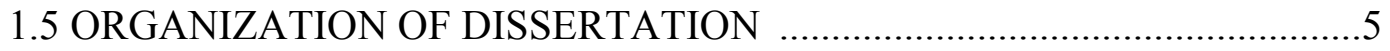

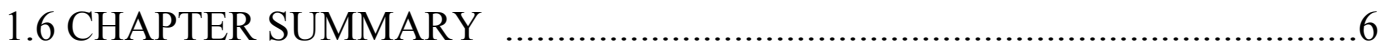

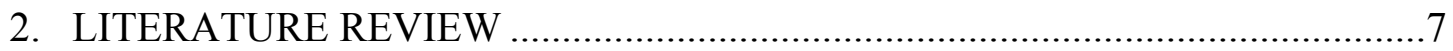

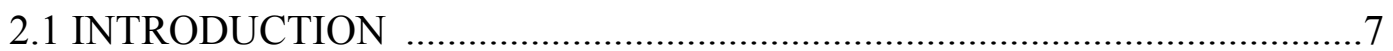

2.2 INTEGRATED PROJECT DELIVERY ….............................................

2.2.1 KEY PARTICIPANTS BOUND TOGETHER AS EQUALS (IPD CONTRACT) …........................................................................... 10

2.2.2 EARLY INVOLVEMENT OF KEY PARTICIPANTS ......................11

2.2.3 INTENSIFIED DESIGN .............................................................. 11

2.2.4 JOINTLY DEVELOPED PROJECT TARGET CRITERIA .................12

2.2.5 SHARED FINANCIAL RISK AND REWARD BASED ON PROJECT OUTCOME …...............................................................13

2.2.6 LIABILITY WAIVERS BETWEEN KEY PARTICIPANTS ..............13

2.2.7 FISCAL TRANSPARENCY BETWEEN KEY PARTICIPANTS ......14

2.2.8 COLLABORATIVE DECISION-MAKING ......................................14

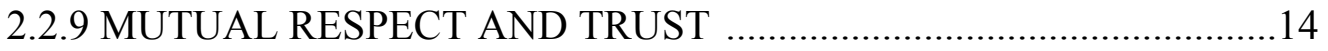

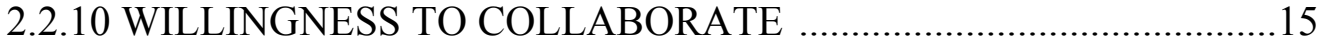

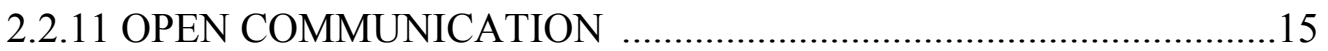

2.3 INFORMATION FLOW IN A CONSTRUCTION PROJECT .....................15

2.4 LEVELS OF INTEGRATION IN CONSTRUCTION ................................ 17

2.4.1 INFORMATIONAL INTEGRATION .............................................. 17

2.4.2 ORGANIZATIONAL INTEGRATION .........................................18

2.4.3 CONTRACTUAL INTEGRATION …............................................... 18

2.5 EXISTING RESEARCH ON INTEGRATED INFORMATION

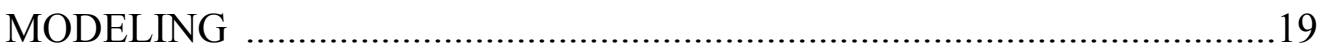

2.6 CONSTRUCTION INDUSTRY INSTITUTE'S INFORMATION

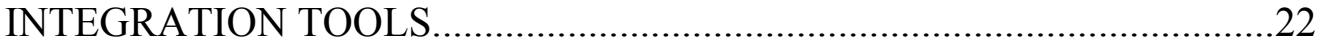

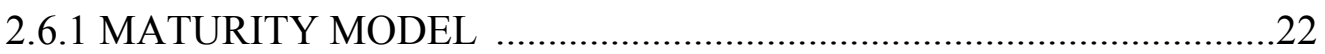

2.6.1.1 GENERAL INFORMATION INTEGRATION MATURITY

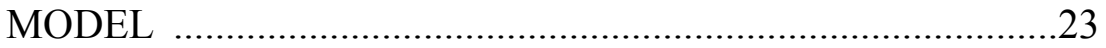

2.6.1.2 BUSINESS FUNCTION INFORMATION INTEGRATION

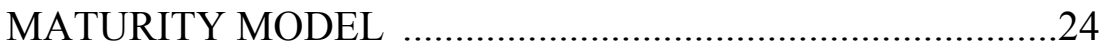

2.6.2 INTEGRATION OPPORTUNITY ASSESSMENT TOOL .................24

2.6.3 LIMITATIONS OF THE CII MODEL ............................................24 
2.7 INFORMATION AND COMMUNICATION TECHNOLOGY (ICT)

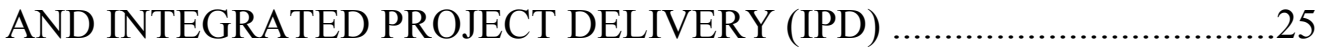

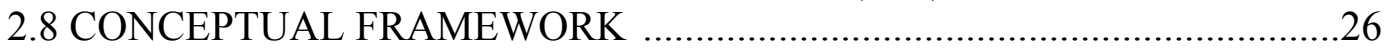

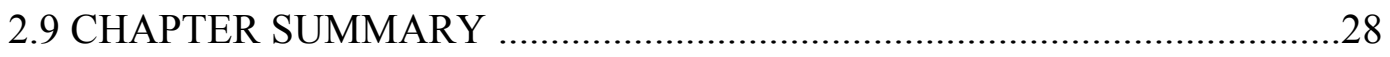

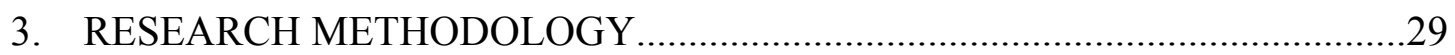

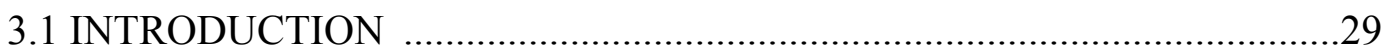

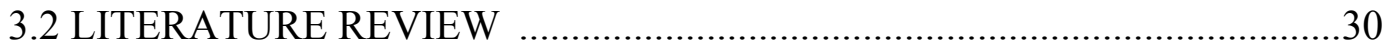

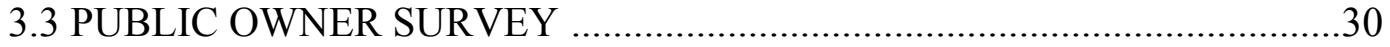

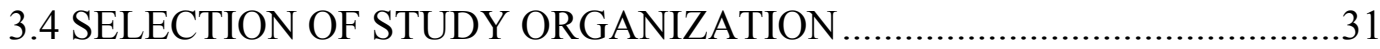

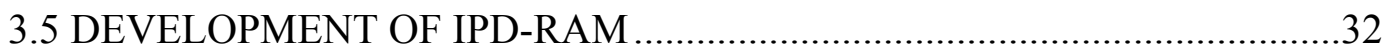

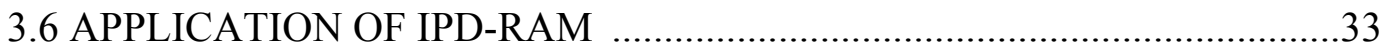

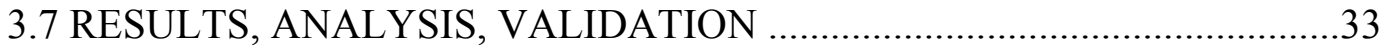

3.7.1 VALIDATION THROUGH FOCUS GROUP ………............................34

3.7.2 MODEL VALIDATION THROUGH FIELD EXPERTS ......................35

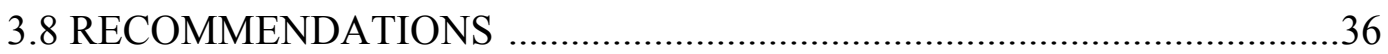

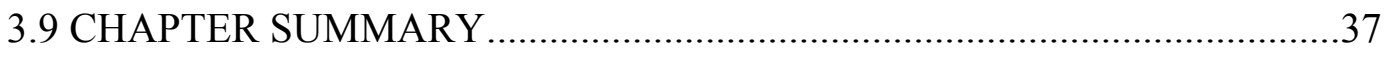

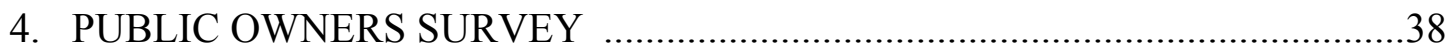

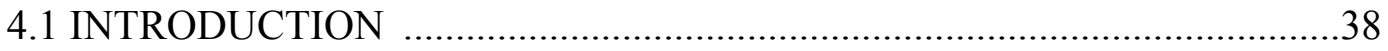

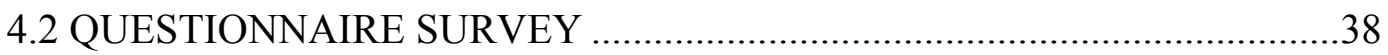

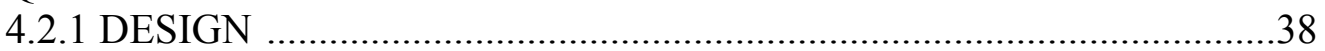

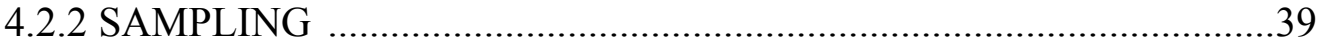

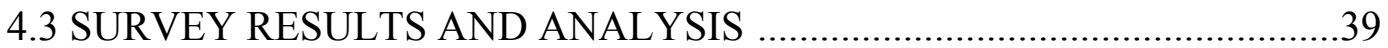

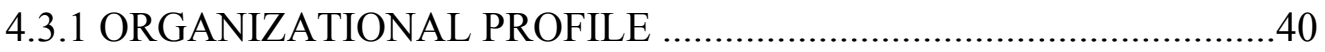

4.3.1.1 ORGANIZATION TYPE …………………….......................40

4.3.1.2 TYPE AND NUMBER OF CONSTRUCTION PROJECTS ....40

4.3.1.3 ORGANIZATION SIZE AND ANNUAL CONSTRUCTION

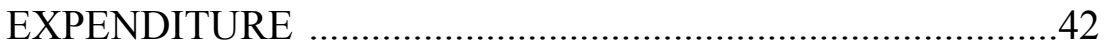

4.3.1.4 IN-HOUSE/OUTSOURCED ACTIVITIES ...............................43

4.3.1.5 EXISTENCE OF IT DEPARTMENT TO ASSIST

CONSTRUCTION PROJECTS..................................................43

4.3.2 PROJECT DELIVERY PRACTICES IN PUBLIC CONSTRUCTION

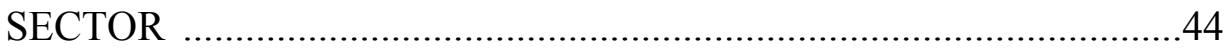

4.3.2.1 COMMONLY USED DELIVERY SYSTEMS ..........................44

4.3.2.2 PROJECT FACTORS INFLUENCING DELIVERY METHOD SELECTION ………………………………….....45

4.3.2.3 INFLUENCE OF CONTRACT TYPE OF PROJECT DELIVERY METHOD .............................................................

4.3.2.4 PROJECT PERFORMANCE UNDER CURRENT PROJECT

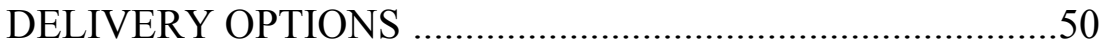

4.3.3 RELATIONSHIP BETWEEN ICT AND IPD …………………….......52

4.3.3.1 ICT-IPD RELATIONSHIP DATA ANALYSES …...................55

4.3.3.1.1 RESEARCH QUESTION 1.....................................58

4.3.3.1.2 RESEARCH QUESTION 2........................................59 
5. INTEGRATED PROJECT DELIVERY READINESS ASSESSMENT

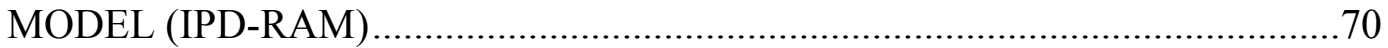

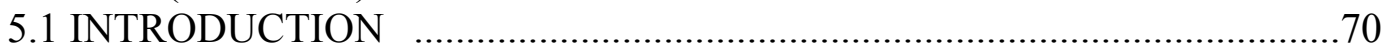

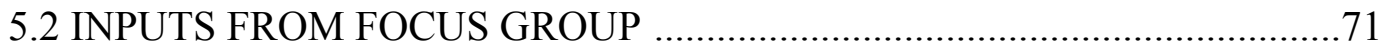

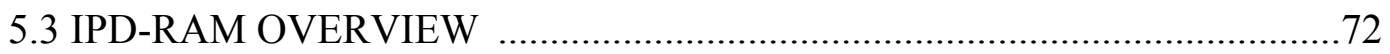

5.4 IPD PRINCIPLES AND THEIR SCORING MECHANISMS ………….......76

5.4.1 EARLY INVOLVEMENT OF KEY PARTICIPANTS (EIKP) .............78

5.4.2 COLLABORATIVE DECISION-MAKING (CDM) ............................79

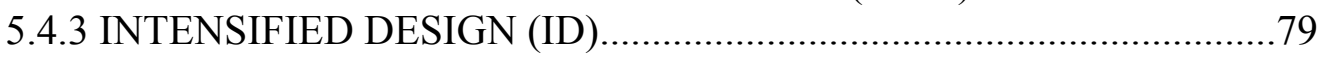

5.4.4 JOINTLY DEVELOPED PROJECT TARGET CRITERIA (JDPTC)..81

5.4.5 FISCAL TRANSPARENCY (FT) …………………………......... 81

5.4.6 LIABILITY WAIVERS BETWEEN KEY PARTICIPANTS (LWKP) 82

5.4.7 SHARED FINANCIAL RISKS AND REWARDS BASED ON

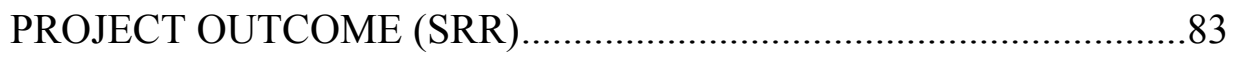

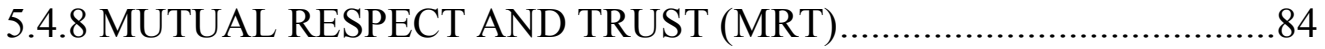

5.4.9 WILLINGNESS TO COLLABORATE (WTC) ………..........................86

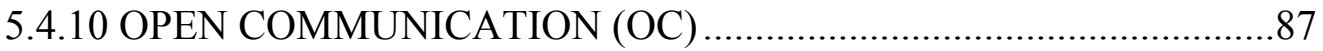

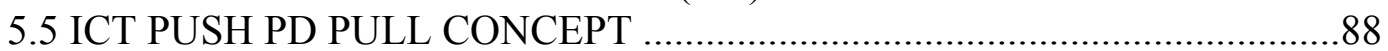

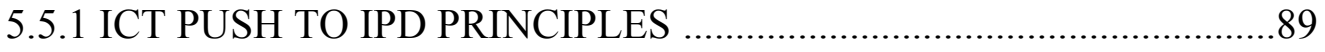

5.5.1.1 ICT PUSH TO CDM …………...........................................89

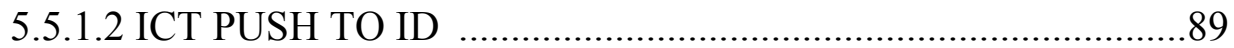

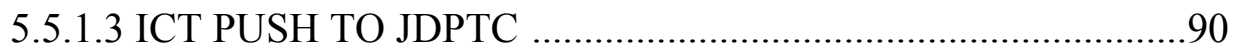

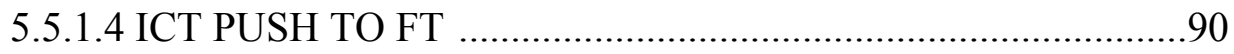

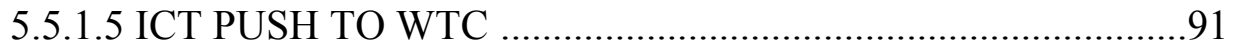

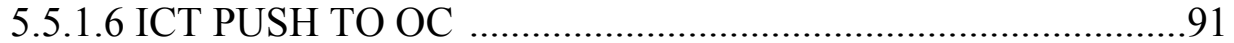

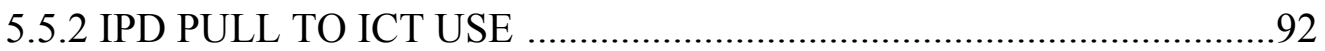

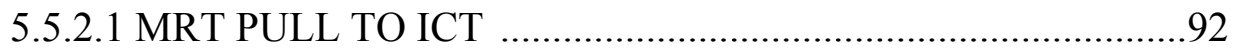

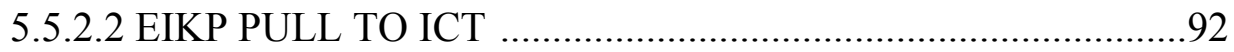

5.5.2.3 LWKP PULL TO ICT …………………..........................93

5.5.2.4 SRR PULL TO ICT …………………….........................93

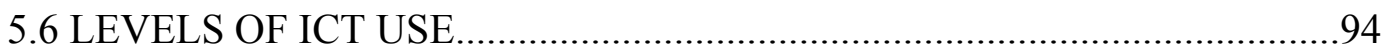

5.7 RELATIONSHIP BETWEEN IPD PRINCIPLES AND PROJECT

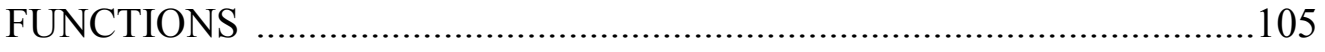

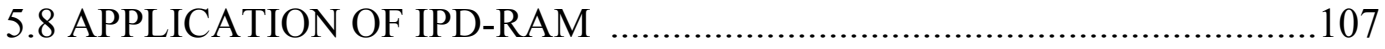

5.8.1 HYPOTHETICAL CASE $\alpha$ DESCRIPTION ......................................107

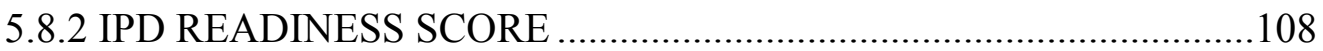

5.8.3 DETERMINATION OF ICT LEVEL ................................................109

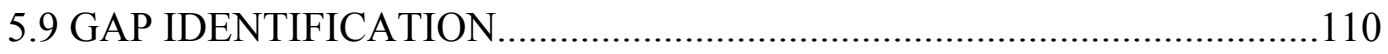

5.10 VALIDATION OF MODEL …………..........................................111

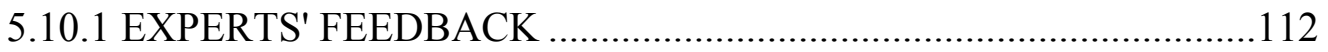

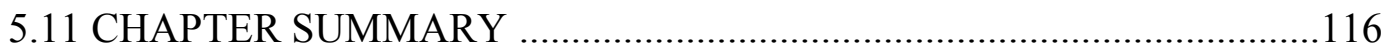




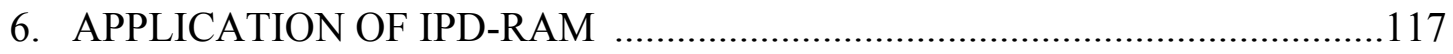

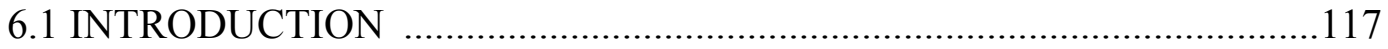

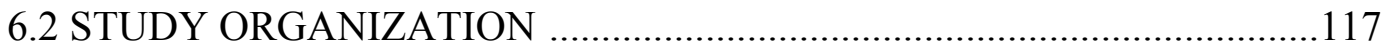

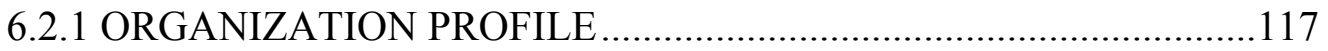

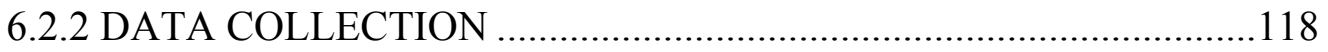

6.3 APPLICATION OF IPD-RAM ON CASE PROJECTS ……….................122

6.3.1 CASE A- ACADEMIC HEALTH CENTER 4 ……............................122

6.3.1.1 PROJECT DESCRIPTION...................................................123

6.3.1.2 DETERMINATION OF IPD READINESS SCORE ................123

6.3.1.3 DETERMINATION OF ICT LEVEL ....................................125

6.3.1.4 IPD READINESS REPORT .................................................126

6.3.2 CASE B- SCHOOL OF INTERNATIONAL AND PUBLIC

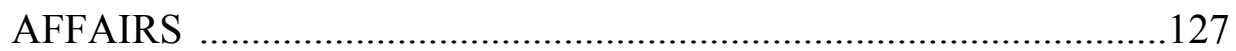

6.3.2.1 PROJECT DESCRIPTION..................................................129

6.3.2.2 DETERMINATION OF IPD READINESS SCORE ................129

6.3.2.3 DETERMINATION OF ICT LEVEL ...................................131

6.3.2.4 IPD READINESS REPORT ...............................................132

6.3.3 CASE C- MARINE BIOLOGY BUILDING ………...........................134

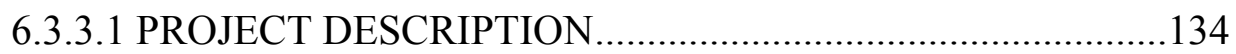

6.3.3.2 DETERMINATION OF IPD READINESS SCORE ................135

6.3.3.3 DETERMINATION OF ICT LEVEL ………………............135

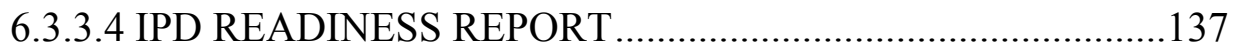

6.3.4 CASE D- PARKVIEW HOUSING …………….............................139

6.3.4.1 PROJECT DESCRIPTION..................................................139

6.3.4.2 DETERMINATION OF IPD READINESS SCORE ................140

6.3.4.3 DETERMINATION OF ICT LEVEL ...................................140

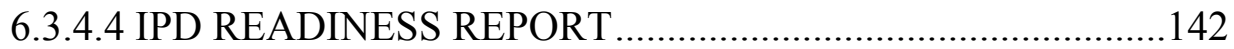

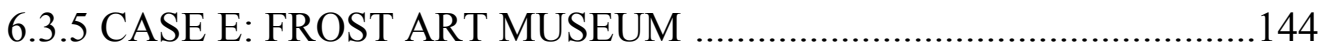

6.3.5.1 PROJECT DESCRIPTION....................................................144

6.3.5.2 DETERMINATION OF IPD READINESS SCORE ................145

6.3.5.3 DETERMINATION OF ICT LEVEL .....................................146

6.3.5.4 IPD READINESS REPORT ..................................................147

6.3.6 CASE F: MIXED USE COLLEGE OF BUSINESS BUILDING

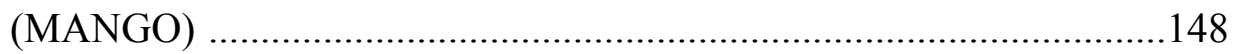

6.3.6.1 PROJECT DESCRIPTION...................................................148

6.3.6.2 DETERMINATION OF IPD READINESS SCORE ................149

6.3.6.3 DETERMINATION OF ICT LEVEL ...................................149

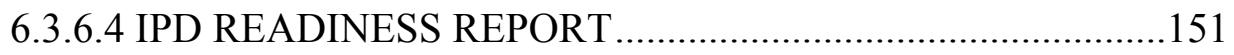

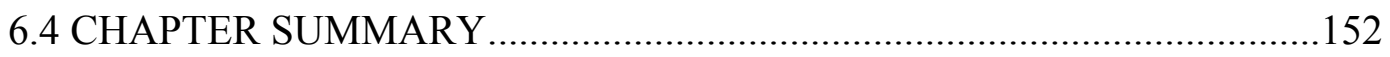

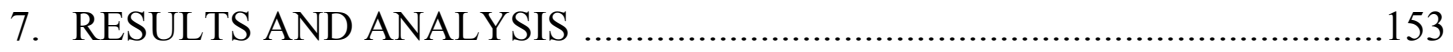

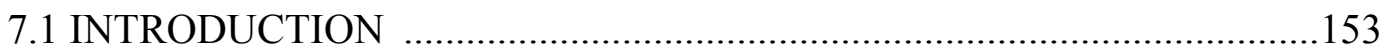

7.2 IPD READINESS SCORES FOR CASE STUDY PROJECTS ..................153

7.2.1 EFFECTS OF EIKP ON IPD READINESS......................................156

7.2.2 EFFECTS OF LWKP ON IPD READINESS ....................................157 
7.2.3 EFFECTS OF SRR ON IPD READINESS 158

7.2.4 EFFECTS OF MRT ON IPD READINESS 159

7.3 EFFECTS OF ICT PUSH ON IPD PRINCIPLES 160

7.3.1 COMPARISON OF CASE A AND CASE C - INTENSIFIED DESIGN. .161

7.3.2 COMPARISON OF CASE B AND CASE D - WILLINGNESS TO COLLABORATE .166

7.3.3 COMPARISON OF CASE A AND CASE D - OPEN COMMUNICATION

7.3.4 COMPARISON OF CASE E AND CASE F - FISCAL TRANSPARENCY .172

7.3.5 COMPARISON OF CASE B AND CASE F - COLLABORATIVE DECISION MAKING

7.3.6 COMPARISON OF CASE E AND CASE F - JOINTLY DEVELOPED PROJECT TARGET CRITERIA 175

7.4 COMPARISON OF ICTS BETWEEN CASE B AND CASE F

7.5 IPD READINESS SCORES FOR HYPOTHETICAL CASE $\beta$

7.5.1 COMPARISON OF CASE F AND CASE $\beta$ 179

7.6 VALIDATION OF MODEL APPLICATION 181

7.7 CHAPTER SUMMARY 184 185 188

8. RECOMMENDATIONS FOR IMPROVING IPD READINESS 189

8.1 INTRODUCTION

8.2 ICT OPPORTUNITIES AND RECOMMENDATIONS 189

8.2.1 UTILIZE BIM FOR GENERATING PROJECT CONCEPT SCENARIOS

8.2.2 DEVELOP E-SPECIFICATIONS USING e-SPECS 192

8.2.3 INTEGRATE COST AND SCHEDULES ESTIMATING AND UPDATE WITH BIM MODEL

8.2.4 INVEST IN PROJECT MANAGEMENT INFORMATION SYSTEM (PMIS)

8.3 RECOMMENDATIONS FOR IMPROVING ORGANIZATIONAL

PROCEDURES

8.3.1 DEMAND BIM AS DESIGN AND CONSTRUCTION

DELIVERABLE

8.3.2 PERFORM CONTINUOUS VALIDATION OF DESIGN 200

8.3.3 ESTABLISH COLLABORATIVE DECISION-MAKING TEAM AND PROCESSES

8.3.4 ENCOURAGE CO-LOCATION OF TEAMS

8.4 RECOMMENDATIONS FOR CONTRACTUAL CHANGES ……...............203

8.4.1 IMPROVE TEAM SELECTION CRITERIA .205

8.4.2 SHARE PERFORMANCE BASED INCENTIVES AMONG

PARTICIPANTS .206

8.4.3 LIMIT LIABILITIES AMONG PROJECT PARTICIPANTS 207

8.4.4 INVOLVE SUBCONTRACTORS EARLY IN DESIGN .208 


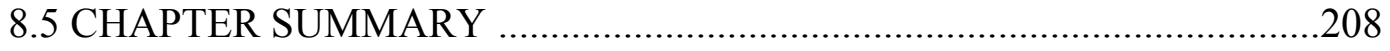

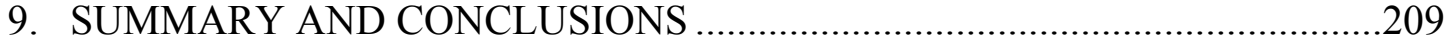

9.1 SUMMARY OF RESEARCH AND ITS OUTCOMES …….....................209

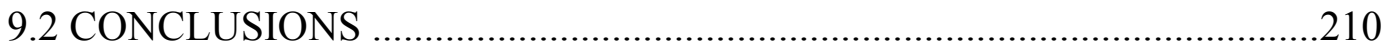

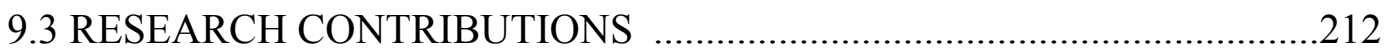

9.4 LIMITATIONS AND RECOMMENDATIONS FOR FUTURE

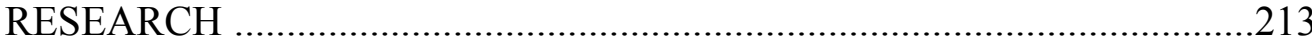

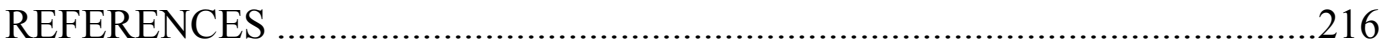

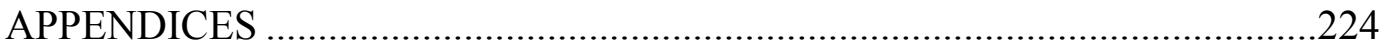

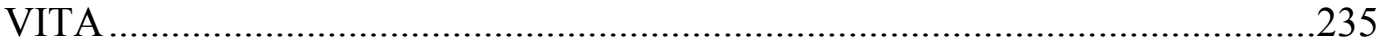




\section{LIST OF TABLES}

TABLE

PAGE

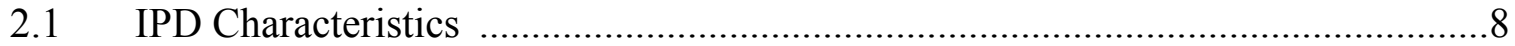

2.2 IPD in the Context of Organizational Responses and Integrations .......................27

4.1 In-House / Outsourcing Practices of Organizations .............................................4

4.2 Significant Factors of Project Delivery Method Selection ...................................46

4.3 Somewhat Significant Factors of Project Delivery Method Selection .................47

4.4 Not Significant Factors of Project Delivery Method Selection ...............................48

4.5 Significant Contract Types for Project Delivery Method Selection ......................49

4.6 Somewhat Significant Contract Types for Project Delivery Method Selection ....49

4.7 Not Significant Contract Types for Project Delivery Method Selection …….......50

4.8 Mapping of Six IPD Characteristics to Two Main IPD Characteristic

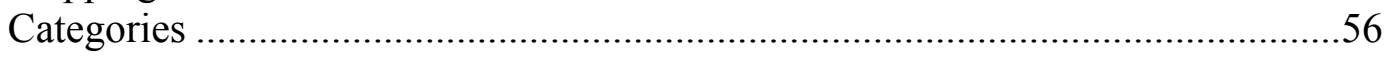

4.9 Responses for the Potential of IPD Characteristics' Contribution to the Project Delivery System Effectiveness .......................................................................6

4.10 Responses for the Potential that ICT Use Fosters the IPD Characteristics ...........61

4.11 Descriptive Statistics: ICT Score and Documents' Transfer Type .......................63

4.12 Descriptive Statistics: PIFI Indices by the Degree of ICT Use ...........................63

$4.13 \quad$ T-test Results for the Second Hypothesis ……………….................................64

4.14 Descriptive Statistics: PIFI Overall Index by Degree and Type of ICT Use ........65

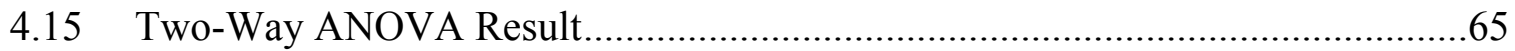

5.1 Links between Survey Findings and Model Components ………………...........70

5.2 Evolution of IPD Definition ...........................................................................77

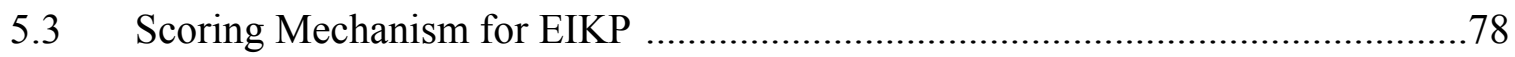




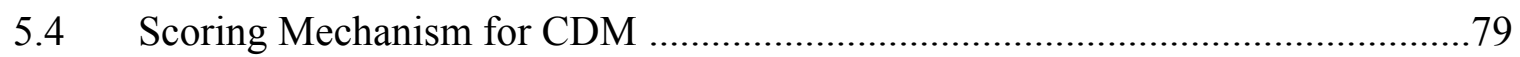

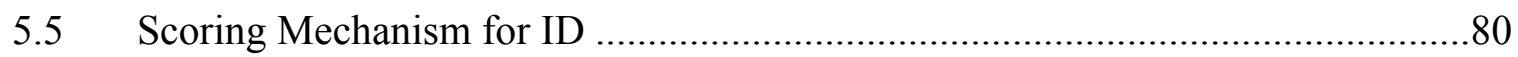

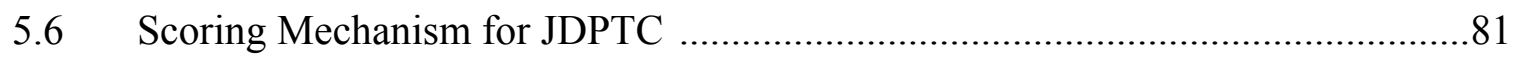

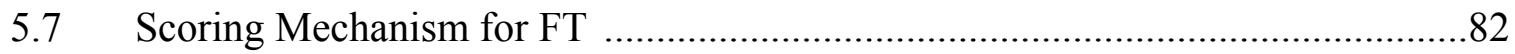

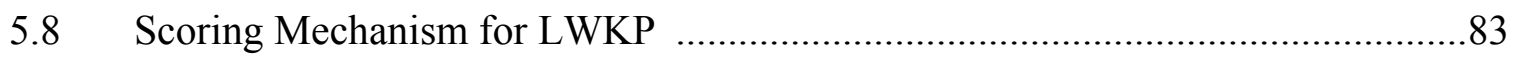

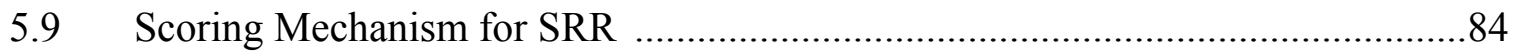

5.10 Classification of Prior Team Experience …………...........................................85

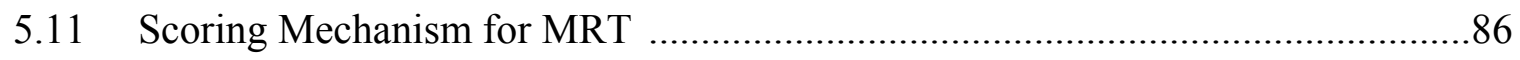

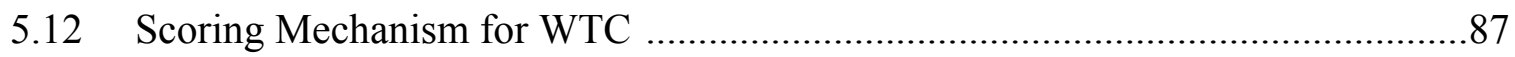

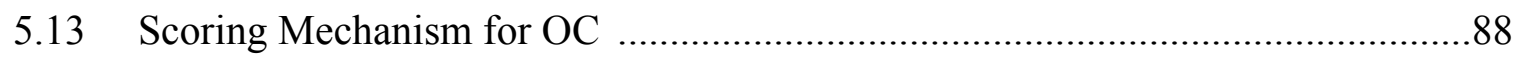

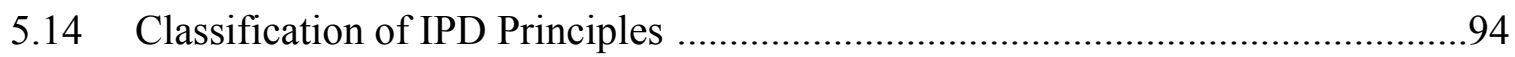

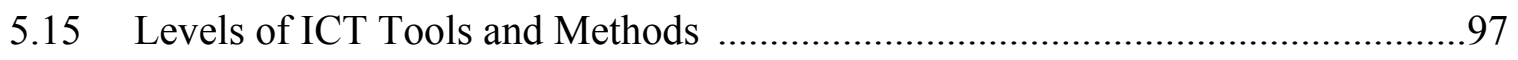

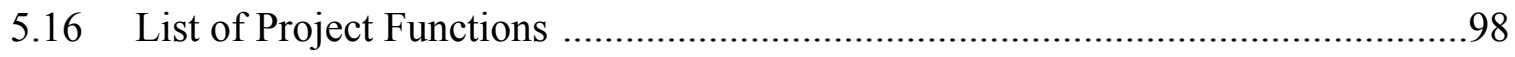

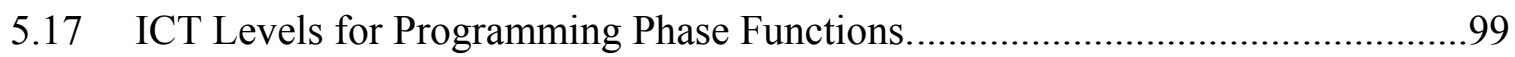

5.18 ICT Levels for Schematic Design Phase Functions .............................................100

5.19 ICT Levels for Design Development Phase Functions …………………….......101

5.20 ICT Levels for Construction Documentation Phase Functions ..........................102

5.21 ICT Levels for Construction Phase Functions ……………………………........103

5.22 IPD Principles and Project Functions …………...........................................106

5.23 IPD Readiness Score of Hypothetical Case a …...............................................109

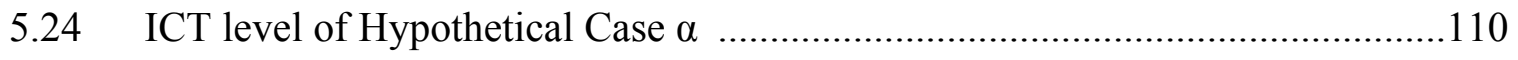

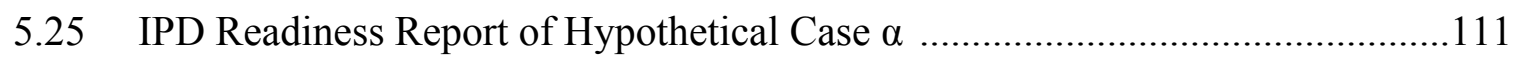

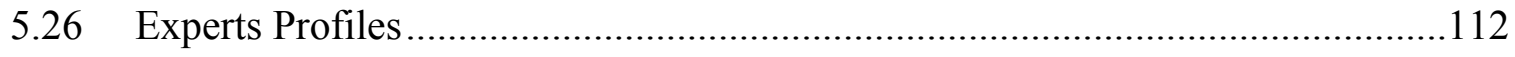


6.1 List of Selected Case-Study Projects .................................................................118

6.2 Information Collected and Sources of Information .........................................121

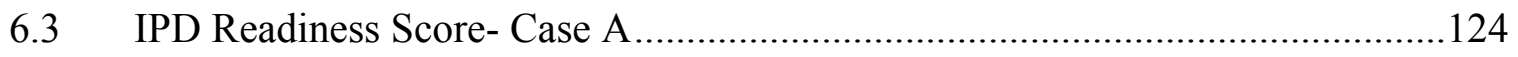

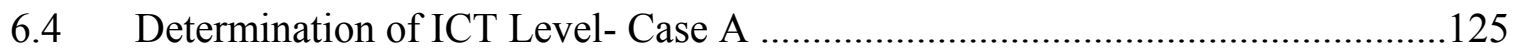

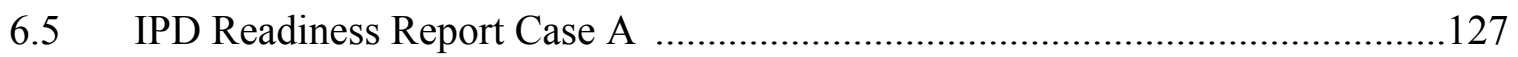

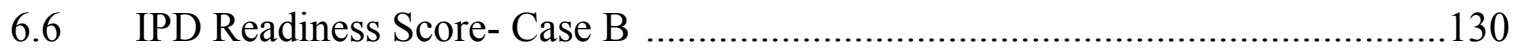

6.7 Determination of ICT Level- Case B ...........................................................131

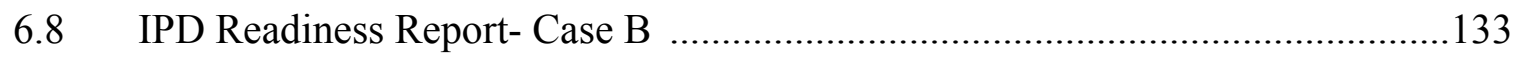

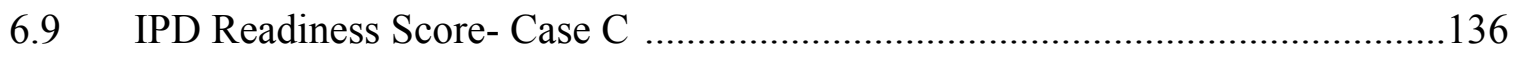

6.10 Determination of ICT Level- Case C ..............................................................137

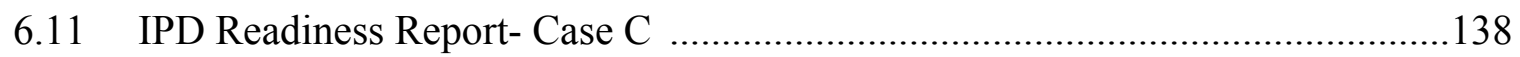

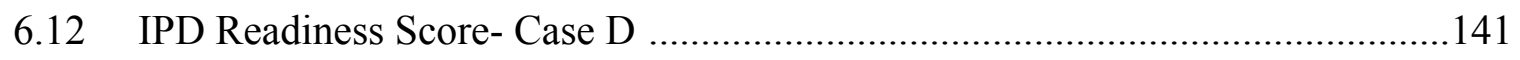

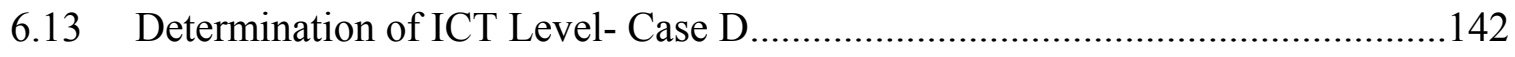

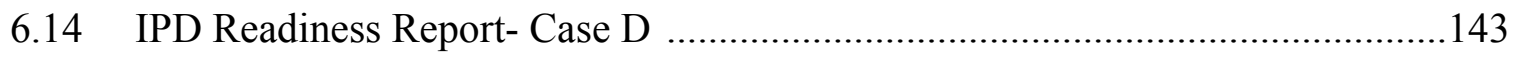

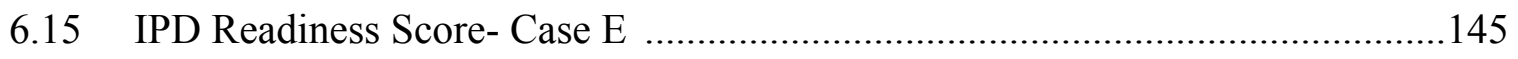

6.16 Determination of ICT Level- Case E ...............................................................146

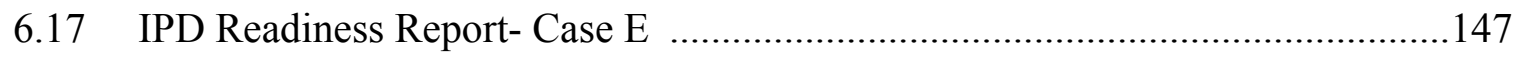

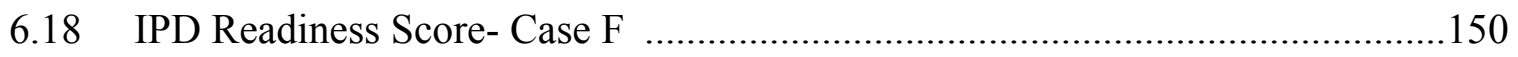

6.19 Determination of ICT Level- Case F …………….....................................151

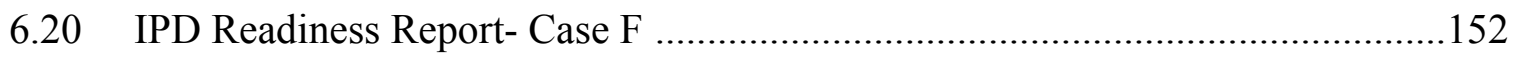

7.1 IPD Readiness Scores of the Case Projects ....................................................153

7.2 Project Functions' ICT Levels of the Case Projects...........................................154

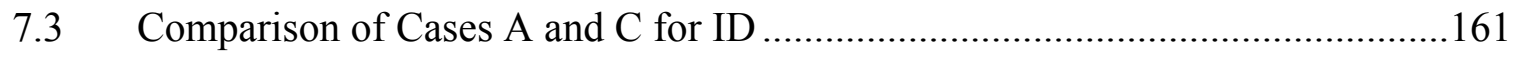


7.4 Comparison of Cases B and D for WTC .167

7.5 Comparison of Cases C and F for WTC 168

7.6 Comparison of Cases A and D for OC.

7.7 Comparison of Cases $\mathrm{E}$ and $\mathrm{F}$ for FC . 173

7.8 Comparison of Cases $\mathrm{B}$ and $\mathrm{F}$ for CDM

7.9 Comparison of Cases E and F for JDPTC .175

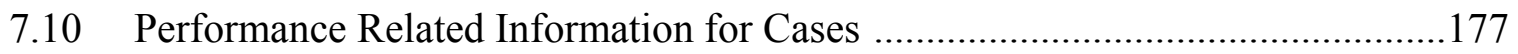

7.11 Comparison of Cases for Performance Indicators ......................................... 178

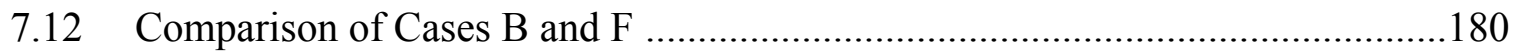

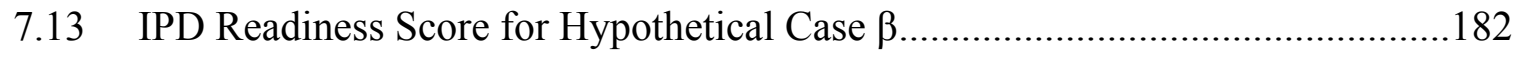

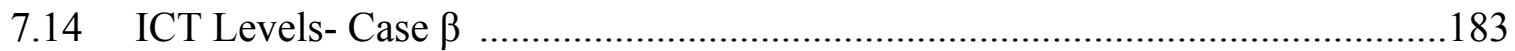

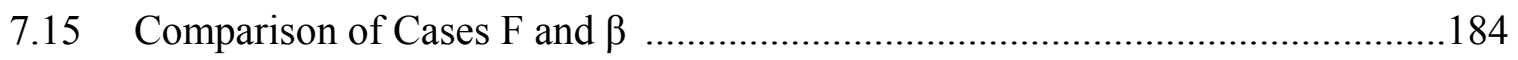

8.1 Comparison of ICT Levels - Programming Phase ........................................190

8.2 Comparison of ICT Tools and Methods between Case F and Case $\beta$ at Programming Stage

8.3 Comparison of ICT Tools and Methods for Development of Specifications

8.4 Comparison of ICT Tools and Methods between Case F and Case $\beta$ for Cost and Schedules

8.5 Comparison of Case A and Case D - RFIs Management Methods 195

8.6 Comparison of ICT Tools and Methods between Case F and Case $\beta$ for PMIS 196

8.7 Comparison of ICT Tools and Methods for Design and Reviews 


\section{LIST OF FIGURES}

FIGURE

PAGE

2.1 Collaboration, Integrated Information, and the Project Lifecycle in Building Design and Construction and Operation (WP-1202, August 2004)

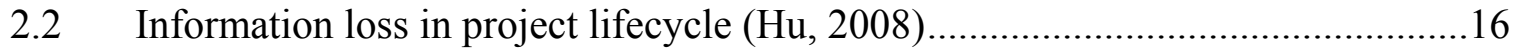

2.3 Use of BIM in project life cycle (Smart Market Report, 2007) ..........................21

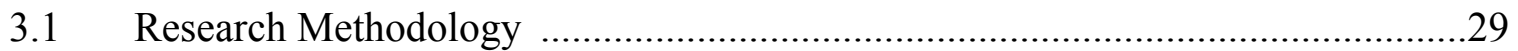

4.1 Respondent Organization Type .................................................................. 40

4.2 Types of Construction Projects Undertaken by Respondent Organizations ........41

4.3 Number of Projects Undertaken by the Organization Annually .........................42

4.4 Organization or Unit Size by Number of Employees .....................................43

4.5 Annual Construction Expenditure of Organization Surveyed .............................44

4.6 IT Department to Assist Construction Projects ............................................45

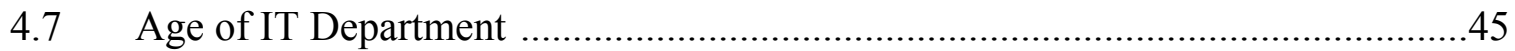

4.8 Distribution of Project Delivery Methods .................................................... 46

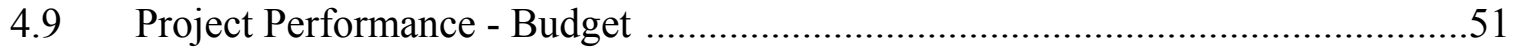

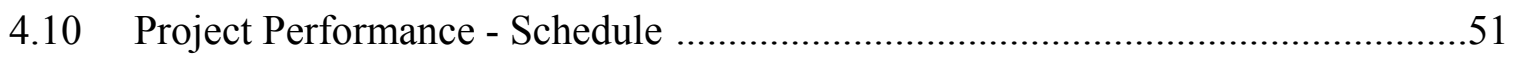

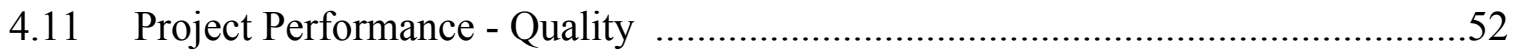

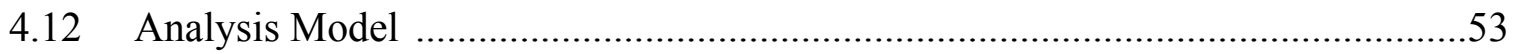

4.13 Mapping of the Research Questions and Data Sources ......................................56

4.14 Classification of groups based on Degree and Type of ICT use ........................59

4.15 Interaction effect of type of ICT use and degree of ICT use for the perception about the impact of ICT on IPD 
5.1 Schematic Representation of IPD-RAM .................................................. 74

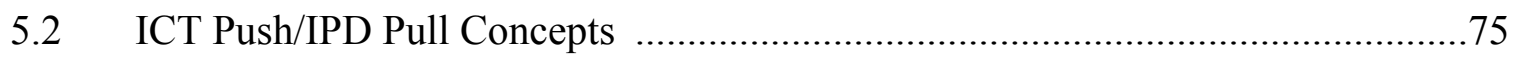

5.3 Example of Mapping of IPD Principles and ICT Levels through Project Functions .75

6.1 Organizational Chart of Facilities Management Department, FIU .....................120

7.1 Case A, and C Comparisons for ID Readiness and Level of ICT .....................163

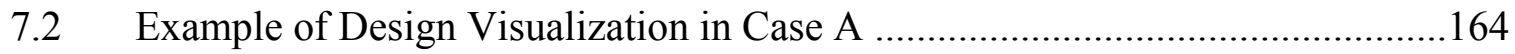

7.3 Example of Design Visualization in Case C ................................................165

7.4 Case C, and F Comparisons for WTC Readiness and Level of ICT ..................169

7.5 Case A and D Comparisons for OC Readiness and Level of ICT ....................171

7.6 Case B and F Comparisons for CDM Readiness and Level of ICT ..................174

7.7 Case E and F Comparisons for JDPTC Readiness and Level of ICT ................176

8.1 State-by-State Map for CM-at-Risk Use on Public Building Projects (Source: AGC Website) .204

8.2 State-by-State Map for CM-at-Risk Use on Public Building Projects (Source: AGC Website) .205 


\section{LIST OF ACRONYMS}

$\begin{array}{ll}\text { BIM } & \text { Building Information Modeling/ Building Information Model } \\ \text { CDM } & \text { Collaborative Decision-Making } \\ \text { CDMC } & \text { Collaborative Decision-Making and Control } \\ \text { EIKP } & \text { Early Involvement of Key Participants } \\ \text { FT } & \text { Fiscal Transparency } \\ \text { ICT } & \text { Information and Communication Technology } \\ \text { ID } & \text { Intensified Design } \\ \text { IPD } & \text { Integrated Project Delivery } \\ \text { IPD-RAM } & \text { Integrated Project Delivery Readiness Assessment Model } \\ \text { JDPTC } & \text { Jointly Developed Project Target Criteria } \\ \text { JDVG } & \text { Jointly Developed and Validated Goals } \\ \text { SRR } & \text { Shared Financial Risk And Reward Based On Project Outcome } \\ \text { KPBTE } & \text { Key Participants Bound Together as Equals } \\ \text { LWKP } & \text { Liability Waivers between Key Participants } \\ \text { MC } & \text { Multiparty Contract } \\ \text { MRT } & \text { Mutual Respect and Trust } \\ \text { Open Communication }\end{array}$




\section{CHAPTER-1: INTRODUCTION}

\subsection{RESEARCH BACKGROUND}

Project delivery method is one of the most vital choices that influence project success. Halpin and Senior (2010) defined project delivery system as "the organization or the development of the framework relating the organizations required to complete or deliver a project and the establishment of the formal (i.e., contractual) and the informal relationships between these organization." Design-Bid-Build (DBB) is traditionally the most widely used method in public sector construction projects (AIA and AGC 2011; Shrestha et al. 2012). However, this traditional project delivery method has also been criticized for its lack of efficiency causing unnecessary waste, rework, claims and litigations. The main reason lies at the core of delivery method where project participants are fragmented. Additionally, the contract language creates an environment of fear of liabilities and claims. Therefore, often the participants try to protect personal and organizational interests ahead of project interests. Such arrangement generates very few opportunities for integration at informational, organizational and contractual levels.

Alternative project delivery methods have been introduced from time to time to mitigate some of the inefficiencies of the project delivery. The two most common alternatives; $\mathrm{CM}$ at-risk (construction management at risk) and design-build (DB) are attempts to alleviate the problems of fragmentation by involving some of the key participants (architects and constructors) early in the project. These methods have influenced project delivery performance. Research shows that these alternative project delivery methods have certain benefits over traditional methods (Shrestha et al. 2007; 
Ibbs et al. 2003). However, the underlying contractual arrangements in these alternative methods still attempt to shift the risk to one party resulting in an environment where project interests are compromised or jeopardized.

Another aspect related to the project performance is the use of information and communication technology (ICT). Research has shown that ICT use in a construction project has improved the coordination processes and collaboration between the project participants (Nitithamyong and Skibniewski 2004). However, organizational and contractual roadblocks exist and affect the effectiveness of these ICT tools (Lam et al. 2010). Although using advanced ICT tools can significantly enhance the flow of data and work, their potential effectiveness also depends on how well project organizations are integrated. Thus, ICT tools can yield the most benefits when used alongside a delivery method that promotes early involvement and a collaborative working environment among key project participants (Kent and Becerik-Gerber 2010).

Integrated project delivery (IPD) has recently emerged as an alternative to traditional project delivery methods. This method relies on the integration of project participants to achieve project delivery effectiveness. It demands early involvement of key participants to form a project team that collaborates throughout all project phases. The collaboration is enhanced by formal (contractual) measures such as liability waivers, shared risks and rewards and financial transparency and supported by informal measures such as, building mutual trust, and open communication between the project participants (NASFA et al. 2010). It can be achieved by the use of relational contracts (El Asmar et al. 2013; Thomsen et al. 2010) that requires at a minimum that owners, architects and contractors share the risks and rewards of project performance. Such an arrangement 
results in aligning the interests of project participants with the project interests (AIA 2012). The benefits of implementing IPD include enhanced cost and schedule predictability (AIA 2010); better cost, quality and schedule performance, fewer project changes, enhanced communication among participants (El Asmar et al. 2013).

Based on the discussion above, it can be expected that a combination of ICT and IPD in a construction project can foster better coordination processes and collaboration among the project participants. Specifically, ICT tools can greatly facilitate IPD projects, and can enhance effective and timely communication among project participants. While IPD and ICT are generally regarded as a complementary combination for effective project delivery - and it makes great intuitive sense - there has been little or no study conducted to further explore this relationship. This lack of information is particularly true in the public sector construction, which is generally more conservative in adapting new methods or technologies. Certain governmental regulations also hinder adoption of IPD as a project delivery method.

Therefore, it is important to investigate IPD-ICT relationship with an aim to developing a model that can help in identifying, documenting, and measuring enhancing impact of ICT on IPD. With this model, it would be possible to assess IPD readiness of a public owner organization. This model would also be helpful in identifying and eliminating barriers hindering effective IPD implementation.

\subsection{PROBLEM STATEMENT}

While the benefits of IPD and role of ICT in realizing those benefits have been recognized generally, the deployment and adoption of IPD in the US construction 
industry has been very slow, particularly in the public sector. One factor contributing to slow adoption of IPD is lack of experience and understanding of IPD in the public sector (Kent and Becerik-Gerber 2010). It is important to fill this gap in knowledge and understanding with IPD (Cleves Jr. and Gallo 2012).

To improve understanding, it is necessary to provide public owners means to measure readiness of their organizations for adoption of IPD, so that hindrances in the way to improve it can be identified and mitigated. Recent advances in the field of ICT are making effective information modeling feasible. Effective information and communication is essential for integrated project delivery system to function effectively. Thus, ICT can greatly facilitate IPD projects. Therefore, it is important to investigate IPD-ICT relationship and to find a way to measure the impacts of ICT on IPD.

This research study is an effort to address the aforementioned need by developing an IPD Readiness Assessment Model (IPD-RAM). The model developed as a result of this research attempts to determine the IPD readiness of a public owner organization taking selected IPD principles in consideration. This model for selected project functions also determines level of ICT use. The subsequent analysis results into a set of recommendations, which if implemented have potential to improve IPD readiness of the organization.

\subsection{RESEARCH QUESTIONS}

Following are the research questions addressed in this research.

1. What are the key principles that define a project as an IPD project? Is IPD considered effective? 
2. What is the relationship between ICT and IPD? Does ICT foster IPD? What is the perception in the public construction sector?

3. How can IPD readiness of an owner organization be assessed?

4. How can ICT improve IPD readiness?

\subsection{RESEARCH OBJECTIVES AND SCOPE}

The main objective of this research is to develop an IPD readiness assessment model for owner organizations. The model provides schematic procedure to assess IPD readiness and to recommends how to leverage ICT for facilitating and enhancing IPD in construction projects. The aim is to identify the issues and suggest ways to resolve those so that owners can realize the benefits of IPD by effectively utilizing ICT.

As mentioned above, the implementation of IPD in public sector is more challenging than in private sector. It is mainly because, in general, public procurement laws are more restrictive and do not allow effective implementation of IPD principles. In addition, experience regarding and understanding of IPD in public sector is lacking. Although the idea of 'IPD readiness assessment model' is applicable to any construction organization, the scope of this research study is limited to public owner organizations. Case study approach is utilized in this research study and the model is applied to six case projects (case studies) owned by a single owner organization.

\subsection{ORGANIZATION OF DISSERTATION}

Chapter 1 introduced the research. An extensive literature review is provided in Chapter 2. The research approach and methodology is discussed in detail in Chapter 3. 
The findings of the survey conducted among the public owners are presented in Chapter 4. IPD Readiness Assessment Model (IPD-RAM) is presented in Chapter 5.

Chapter 6 describes the application of model and provides details of case studies. The results of implementation of the model and analysis are presented in Chapter 7. These results are in the form of specific ICT enhancements that have the potentials to increase IPD readiness. Opportunities to improve IPD readiness through ICT enhancements are identified and presented in Chapter 8. Organizational measures that can be taken for implementation of IPD are also pointed out in this chapter. c In the last chapter (Chapter 9), summary and conclusions are presented. Research contributions and opportunities for future studies are highlighted and limitations of the study are also pointed out in this chapter.

\subsection{CHAPTER SUMMARY}

This basic premise of the research study conducted and presented in this dissertation is discussed in this chapter by providing the context regarding the issues involved with project delivery mechanisms. The usefulness of IPD is highlighted. Thereafter, the relationship between IPD and ICT, and how this relationship can help achievement in IPD principles in public owner organizations are discussed. Following the discussion on the context and perspective, problem statement, research questions, objectives, and scope of the research are provided. Finally, chapter-wise organization of this dissertation was provided. A thorough literature review on the research topic and methodology are included in the next chapter. 


\section{CHAPTER-2: LITERATURE REVIEW}

\subsection{INTRODUCTION}

The previous chapter laid the foundation of the research study presented in this dissertation by providing a brief context. A thorough literature review on several aspects of the research is provided in this chapter. Integrated project delivery (IPD) and its characteristics, information flow in construction projects, levels of integration in construction, review of existing research on integrated information modeling, critique on Construction Industry Institute's (CII) information integration tool, and relationship between ICT and IPD are covered. Furthermore, a conceptual framework is presented and discussed to further elaborate and emphasize the foundations of the research presented in this dissertation.

\subsection{INTEGRATED PROJECT DELIVERY}

Integrated Project Delivery ("IPD") is based on the Australian "Alliancing" model, and has its roots in utilization of lean principles and relational form of contract that composes the team behaviors (Sacks 2013). It demands the use of a relational contract where all key participants sign a single agreement. Although new to US, these joint contracts are common in the U.K., Australia, and New Zealand (Gokhale 2011).

Kent and Becerik-Gerber (2010) highlighted that while many organizations are developing guidelines and form of IPD contracts, there is no standard definition of IPD that is accepted and understood by all. The definitions found differ by their approaches and sophistication of contact arrangements and team makeup (Sive 2009). Yet there are 
similarities within most IPD projects and definitions. A summary of IPD characteristics outlined by various researchers is shown in Table 2.1

Table 2.1: IPD Characteristics

\begin{tabular}{|l|l|}
\hline \multicolumn{1}{|c|}{ Authors } & \multicolumn{1}{|c|}{ IPD characteristics } \\
\hline $\begin{array}{l}\text { Kent and Becerik- } \\
\text { Gerber (2010) }\end{array}$ & $\begin{array}{l}\text { Multiparty agreement, early involvement of all parties, shared } \\
\text { risk and reward. }\end{array}$ \\
\hline $\begin{array}{l}\text { Matthews and } \\
\text { Howell (2005) }\end{array}$ & Multiparty contract, share risk and profit. \\
\hline $\begin{array}{l}\text { Forbes and Ahmed } \\
(2010)\end{array}$ & $\begin{array}{l}\text { Multiparty contract, close collaboration of a team for } \\
\text { optimizing the entire project. }\end{array}$ \\
\hline AIA (2007) & $\begin{array}{l}\text { Mutual Respect and Trust, Mutual Benefit and Reward, } \\
\text { Collaborative Innovation and Decision Making, Early } \\
\text { Involvement of Key Participants, Early Goal Definition, } \\
\text { Intensified Planning, Open Communication, Appropriate } \\
\text { Technology, Organization and Leadership. }\end{array}$ \\
\hline AIA (2010) & $\begin{array}{l}\text { Early Involvement of Key Participants, Shared Risk and } \\
\text { Reward, Multi-Party Contract, Collaborative Decision Making } \\
\text { and Control, Liability Waivers Among Key Participants, Jointly } \\
\text { Developed and Validated Project Goals. }\end{array}$ \\
\hline NASFA et al. (2010) & $\begin{array}{l}\text { Multiparty agreement, trust and mutual respect, mutual benefit } \\
\text { and reward, collaborative decision-making, early involvement } \\
\text { of key project participants, early goal definition and intensified } \\
\text { planning, and open communications, liability waivers between } \\
\text { key participants, jointly developed project target criteria. }\end{array}$ \\
\hline
\end{tabular}

All definitions emphasize on early involvement of key participants, decisions by consensus, pooling contingencies, encouraging team performances and creating an environment where all team members strive for achieving project targets, and share its risks and rewards (Autodesk 2008; Gokhale 2011). In most cases, IPD arrangement can be divided into two main elements - collaborative design and construction process, and sharing of financial risks and rewards (Wickersham 2009). 
Although there is no fixed recipe to an IPD project, a project can achieve a certain degree of IPD based on the number and extent of IPD principles implemented. . For this research, IPD principles are adapted from NASFA et al (2010), a joined report entitled "Integrated Project Delivery for Public and Private Owners", with some minor modifications made for clarification purposes. NASFA et al (2010) categorized IPD principles into two major categories - contractual and behavioral. The main difference is, while contractual principles form the basis of the formal agreement in written form, behavioral principles are preference-based principles.

According to NASFA et al. following is the classification of IPD principles into contractual and behavioral categories.

Contractual Principles

- Key Participants Bound Together as Equals (KPBTE)

- Early Involvement of Key Participants (EIKP)

- Intensified Design (ID)

- Jointly Developed Project Target Criteria (JDPTC)

- Shared Financial Risk and Reward Based on Project Outcome (SRR)

- Liability Waivers Between Key Participants (LWKP)

- Fiscal Transparency Between Key Participants (FT)

- Collaborative Decision-Making (CDM)

Behavioral Principles

- Mutual Respect and Trust (MRT)

- Willingness to Collaborate (WTC) 
- Open Communication (OC)

Following is a brief description of each of the IPD principles. The main purpose of this exercise is to introduce the principles as they form the basis of this research study. The selected principles are further discussed in chapter 5.

\subsubsection{KEY PARTICIPANTS BOUND TOGETHER AS EQUALS (IPD CONTRACT)}

NASFA et al. (2010) defined it as "Contractually defined relationship as equals supports [between project participants] collaboration and consensus-based decisions".

For this study, we define it as an IPD contract that is specifically written to deliver a project using a nontraditional contract. Various professional organizations are advancing different types of IPD contracts. American Institute of Architects (AIA) has developed two sets of contracts for IPD. Associated General Contractors of America (AGC) with a coalition of a construction industry group offers a tri-party agreement to encourage IPD goals. Hanson Bridgett's Integrated Form of Agreement (IFOA) has been used in many healthcare sector projects (AIA 2012). Several published case studies also indicated the use of customized IPD contracts developed by the project participants. Irrespective of the variations, the main purpose of all these contracts remain the same, it is to facilitate the integrated project delivery by setting out the terms that promote collaboration between the stake holders and aligning their interests with the project success. The major emphasis in such contracts are decision making procedures; procedures for setting project targets (cost, time, quality etc.); compensation and incentives structures; procedures to address work changes and contingencies; risk 
allocation, including insurance, indemnity, and limitation of liability; transparency and access to project documents and records; and dispute resolution procedures.

\subsubsection{EARLY INVOLVEMENT OF KEY PARTICIPANTS}

Complexity of the project in recent times has increased the importance of early involvement of key participants (Gokhale 2011; NASFA et al. 2010). It is the most important and influential IPD principle. AIA (2007) has highlighted its importance as follows

"Building upon early contributions of individual expertise, these teams are guided by principles of trust, transparent processes, effective collaboration, open information sharing, team success tied to project success, shared risk and reward, valuebased decision making, and utilization of full technological capabilities and support. The outcome is the opportunity to design, build, and operate as efficiently as possible”.

Broader participation is desired in IPD than in traditional methods (AIA 2007) among owner, designer, and general contractor as a minimum (AIA-AGC 2011), and preferably with key trades such as mechanical, electrical, and plumbing subcontractors as well as key vendors (AIA 2007; El Asmar et al. 2013). The purpose of forming an integrated team early in the project is to take advantage of the assortment expertise in the design process to better understanding of probable proposition of design decisions. Also,

it can expedite the construction process by facilitating instantaneous constructability reviews, early purchasing and prefabrication (NASFA et al. 2010; Nikles 2012).

\subsubsection{INTENSIFIED DESIGN}

Design efforts can be strengthened by utilizing the expertise of contractors at the 
design phase. This makes design phase of an IPD project much more intense requiring higher levels of efforts compared to traditional projects and more is accomplished (AIA 2007). However, the advantage lies in the low cost of changes to projects at early phase. Intensified design also allows tighter cost control as well as enhanced ability to achieve all desired project outcomes. The relation between the project phase and design efforts is better understood using Figure 2.1, in which the modified MacLeamy Curve (CURT 2004) shows the relationship between design efforts, ability to impact cost and functional capabilities, and cost of design changes. As depicted, in an IPD project most of the design activities are conducted during the early stage of the project, when designers' ability to influence cost is higher than later stages.

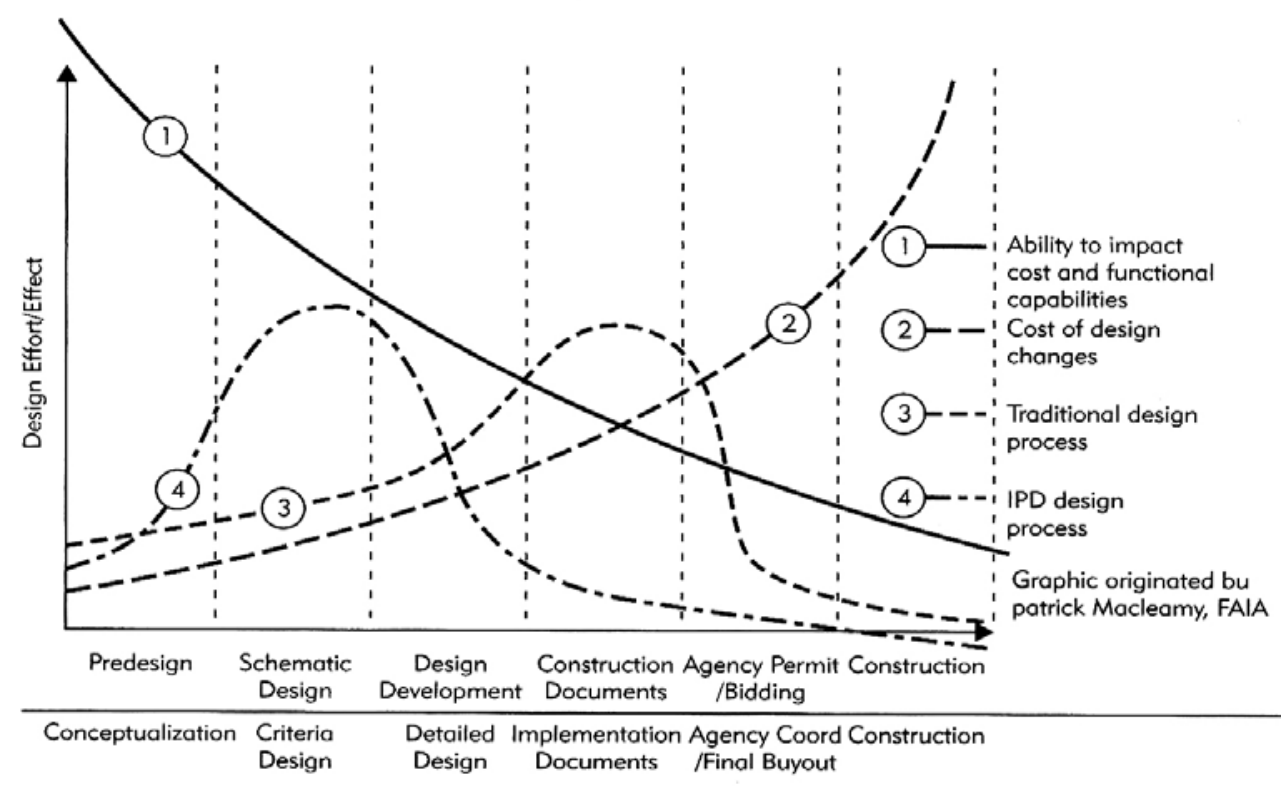

Figure 2. 1: Collaboration, Integrated Information, and the Project Lifecycle in Building Design and Construction and Operation (WP-1202, August, 2004) 


\subsubsection{JOINTLY DEVELOPED PROJECT TARGET CRITERIA}

Cost is a most common project target criterion in a construction project. Owners provide initial planning budget to their team, who develops preliminary cost models which are regularly updated until the design is matured enough to confidently set and document challenging yet attainable target values (Johnson et al. 2013). Schedule and quality targets are also sometimes developed (Thomsen et al. 2010). These target criteria serve as the benchmark to measure project performance and for the compensation adjustments (Ashcraft 2012).

\subsubsection{SHARED FINANCIAL RISK AND REWARD BASED ON PROJECT} OUTCOME

Project participants agree on project targets and tie their individual risk or reward to the overall project outcomes. It persuades the integrated team to employ in "best for project" mentality rather than safeguarding personal interests (Cleves and Gallo 2012; NASFA et al. 2010). According to Hutchinson and Carter (2004, p. 23), a risk/reward model should provide "meaningful financial incentives" for each participant. Therefore, the risks and rewards are linked to entire team collectively rather than linking to individual performances. This characteristic differentiates it from traditional contracts where rewards for early completion or below target cost may be shared with contractors but with no incentives for designers.

\subsubsection{LIABILITY WAIVERS BETWEEN KEY PARTICIPANTS}

It is defined as when key participants waive all claims against each other except 
those caused by willful misconduct or fraud (AIA 2010). It generates an environment conducive for participants to collaborate and share innovative ideas to solve problems without the fear of liability and claims (Ashcraft 2012).

\subsubsection{FISCAL TRANSPARENCY BETWEEN KEY PARTICIPANTS}

It requires that all project participants maintain open books, transparent to other participants. This promotes trust between the team members by keeping the contingencies evident and controllable (NASFA et al. 2010).

\subsubsection{COLLABORATIVE DECISION-MAKING}

In IPD projects, project teams rather than just owner or project managers make decisions. Requiring key project participants to work together on important decisions leverages pools of expertise and encourages joint accountability.

Decision-making procedures are predefined in IPD projects. There could be several arrangements by which decision making hierarchy can be defined. As an example, AIA (2010) explained the procedure of CDM as follows. The governing board generally consists of representatives from owner, designer and contractors. It may also include members from key consultants and key trades. The governing board makes most of the project decisions unanimously. In other cases, most forms of IPD agreement allow a senior management group from multiple entities to make a business decision.

\subsubsection{MUTUAL RESPECT AND TRUST}

Nurturing a positive environment requires deep appreciation for the motivations 
of all project participants: if they do not operate in an environment of mutual respect and trust, performance erodes and participants retreat to "best for stakeholder" behaviors (NASFA et al. 2010).

\subsubsection{WILLINGNESS TO COLLABORATE}

Collaboration is ultimately a behavioral choice. It is important to nurture an environment that supports and encourages participants to choose to collaborate (NASFA et al. 2010).

\subsubsection{OPEN COMMUNICATION}

Communication is defined as the "process of exchange of information between sender and receiver to equalize information on both sides" (Den Otter and Prins 2002). Collaboration requires open, honest communication: if project participants are reluctant to share ideas or opinions, opportunities for innovation and improvement may be missed (NASFA et al. 2010).

It is clear from the above review that effective implementation of IPD principles depend critically on how project information is communicated among the participants. The following is a discussion on how information flows in a construction project.

\subsection{INFORMATION FLOW IN A CONSTRUCTION PROJECT}

Information systems are designed as responses to organizational needs for effective information processing. Organizations generally respond to this need by (a) reducing need for information processing, (b) increasing capacity of information 
processing, and (c) developing coordinating mechanism (Galbraith 1977), listed in order of their relative effectiveness and difficulty of implementation. Any, or a combination, of the above three measures are usually employed by organizations depending on the need and available resources. It must be pointed out, however, that the last one, developing coordinating mechanisms, requires crossing organizational boundary in order to involve other organizations participating in the project.

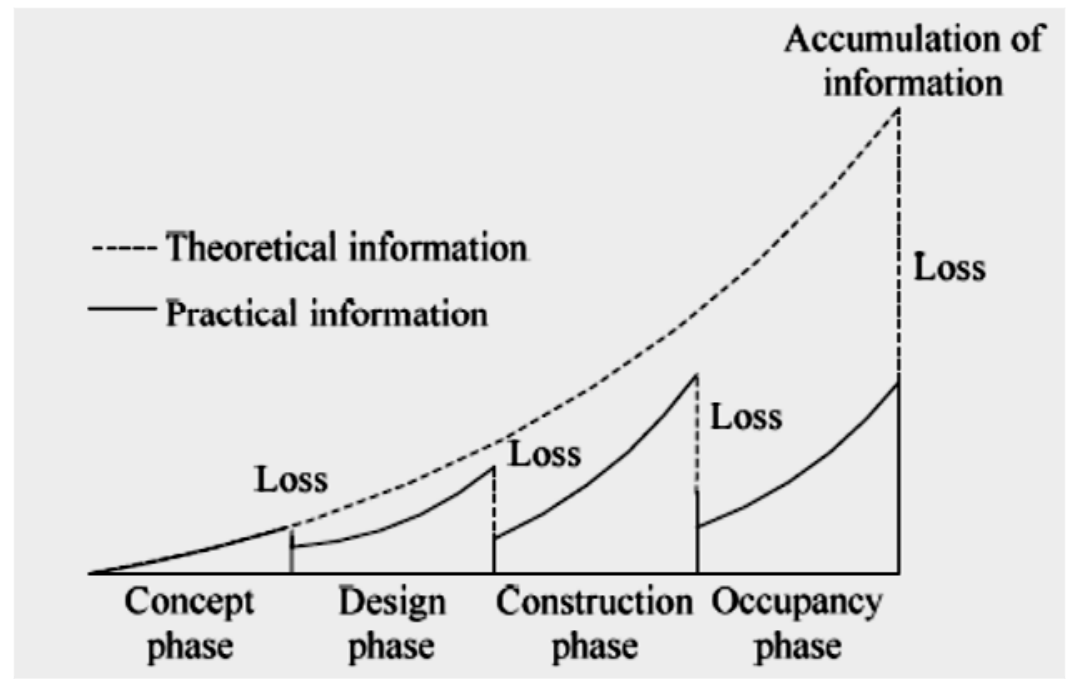

Figure 2.2: Information loss in project lifecycle (Hu, 2008)

In a typical setup of a construction project, information is developed, managed, transmitted, and shared by separate entities, and is naturally scattered, in multiple versions, over several phases of a project. Usually much of the information generated is lost during the project lifecycle under traditional environment due to a lack of effective coordination and system. Information loss results in poor performance and inefficiency (Hu, 2008). Figure 2.2, illustrates conceptually the nature of information loss during a project lifecycle. 
Noble (2007) characterized the difficulties experienced in typical projects as "artifact of a construction process fraught by lack of cooperation and poor information integration." Typical problems cited included: errors, omissions, inefficiencies, coordination problems, cost overruns and productivity losses.

Cao et al. (2002) argue that through integration, many decision-making problems during construction can be solved with consistency in a timely manner. For example, sharing the same site data by multiple contractors would greatly increase the effectiveness of communication among project participants (Ahmad et al. 1995).

Before discussing how information modeling can integrate the project delivery process, a short discussion on different levels of integration will be beneficial.

\subsection{LEVELS OF INTEGRATION IN CONSTRUCTION}

These three levels of integration - informational, organizational and contractual are discussed briefly in the following.

\subsubsection{INFORMATIONAL INTEGRATION}

Informational integration can be achieved by developing effective and efficient information systems. It increases coordination within an organization (intraorganization) or across organizations (inter-organizations). Informational integration supports communication functions, promotes collaboration and facilitates formation of virtual teams (Ahmad, et al 2010). This type of integration is achieved by developing information systems. An information system promotes increased coordination and efficiency within an organization or across organizations. ERP or Enterprise Resource 
Planning, and BIM or Building Information Modeling in the construction sector, are efforts to build effective information systems. Organizational information systems are often developed as a response to the needs of e-commerce and e-business functions.

\subsubsection{ORGANIZATIONAL INTEGRATION}

Integration of this nature usually implies design and production (construction) functions physically in one organizational boundary under a common leadership. The emphasis is on coordination, interaction, and responsiveness. A desire to avoid costly disputes and litigation is the main driving force behind organizational integration. $\mathrm{CM}$ (construction management) companies combining functions of contracting and management under one organization, and design-build project delivery system, combining engineering design and construction under the same entity are examples of organizational integration in construction. ICT-induced informational integrations function well in units that are integrated organizationally.

\subsubsection{CONTRACTUAL INTEGRATION}

Similar to organizational integration, contractual integration also evolved in response to the need for better communication, avoid misunderstandings and eventual litigation. Contractual integration is best achieved by adopting techniques that reduce the needs of bureaucracy, or implementing procedures based on trust and confidence. In construction, specific contract clauses have been developed to implement partnering and alliancing, methods that integrate entities contractually. Integrated Project Delivery (IPD) has evolved as a philosophy that is based on contractual integration. ICT promotes 
contractual integration just the way it helps develop organizational integration. However, several age-old governmental rules and regulations must be modified or adjusted for contractual integrations to function.

In summary, informational integration is the basic type of integration and is the backbone of any management information system. Recent advances made in the field of ICT greatly facilitate informational integration. However, informational integration alone is very limited in scope and cannot be functional without integration at organizational levels. Further, in an industry that is heavily dependent on contracts, a third level of integration, contractual, becomes vital (Mitropoulos and Tatum 2000).

\subsection{EXISTING RESEARCH ON INTEGRATED INFORMATION MODELING}

The development of integrated project systems has been an active area of research throughout the last two decades. Several research programs have been initiated to investigate the methods and technologies required to develop interoperable and integrated systems that can support information sharing and management (e.g., Bjork 1994; Teicholz and Fischer 1994; Brown et al. 1996; Faraj and Alshawi 1999). More recently, FIATECH's Capital Facilities Technology Roadmap project was initiated with the vision of developing technologies to support fully integrated project processes across all phases and functions of the project/facility lifecycle (FIATECH 2006). In Europe, VTT, the Technical Research Centre of Finland, undertook several research projects that aimed to integrate design, engineering, and construction support tools, and to implement integrated design and engineering in distributed, multi partner projects (VTT 2006). A 5-year research program (1998-2002), sponsored by the National Technology Agency of 
Finland, aimed at developing techniques for integrating and managing information through the entire lifecycle of the facilities and across all disciplines (VERA 2006; Froese 2002).

Building information modeling (BIM) is an integrated process built on coordinated, reliable information about a project from design through construction and into operations. By adopting BIM, architects, engineers, contractors and owners can easily create coordinated, digital design information and documentation; use that information to accurately visualize, simulate, and analyze performance, appearance and cost; and reliably deliver the project faster, more economically and with reduced environmental impact. A BIM model can be used to: demonstrate the entire building life cycle, from the processes of construction to facility operation; perform a constructability analysis by observing a construction sequence. Figure 2.3 shows how BIM can be utilized throughout the project life cycle from the conceptual phase to startup and operation phases.

BIM integrates basic computerized components, such as drafting, rendering, 4D modeling, quantity surveying, estimating and scheduling. It means not only using threedimensional intelligent models but also making significant changes in the workflow and project delivery processes (Hardin 2009). It represents a new paradigm within AEC, one that encourages integration of the roles of all stakeholders on a project and has the potential to promote greater efficiency and harmony among players who, in the past, saw themselves as adversaries (Azhar, et al. 2008). BIM provides the framework for an interactive information system originating from designers to contractor and subcontractors and lastly to the owner. 


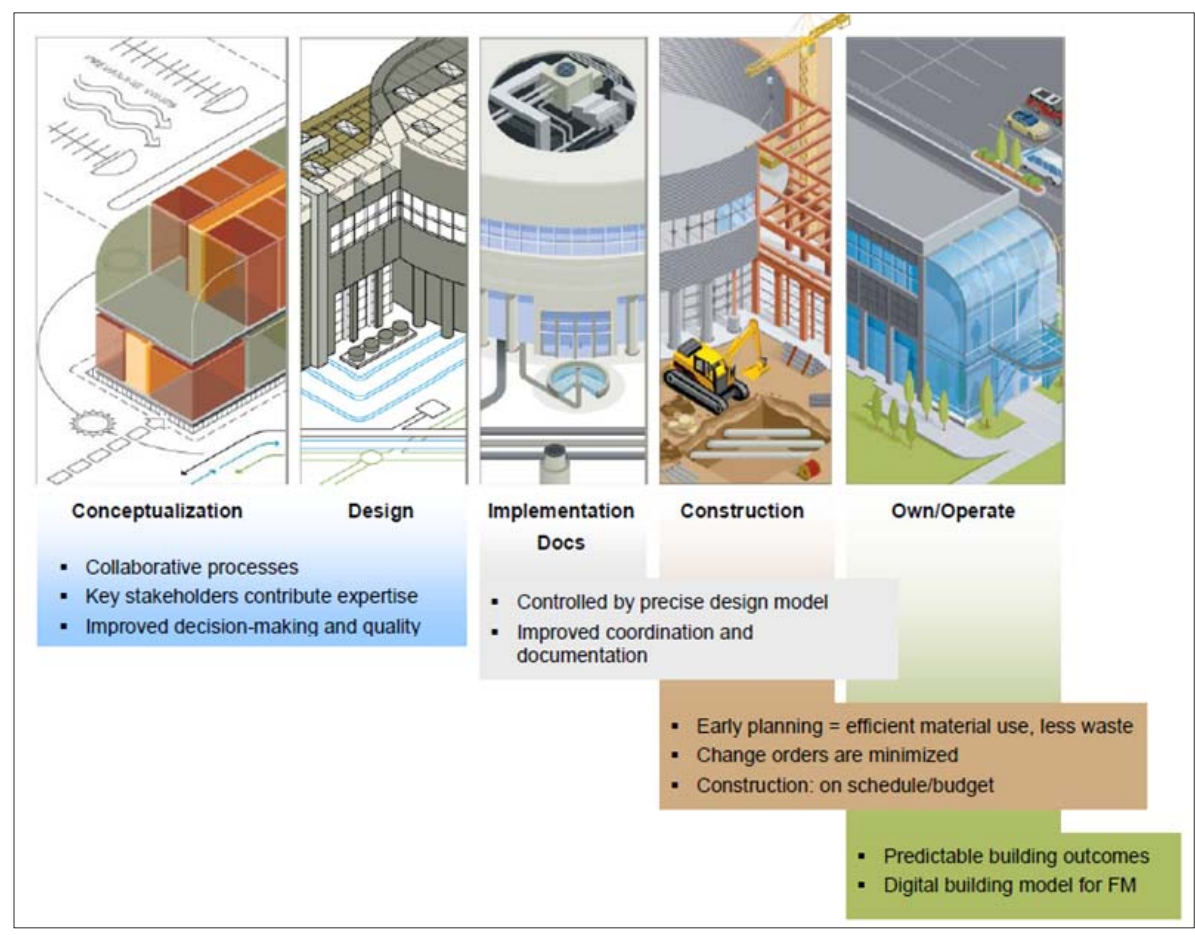

Figure 2.3: Use of BIM in project life cycle (Smart Market Report, 2007)

BIM supports the concept of integrated project delivery, a novel project delivery approach to integrate people, systems, and business structures and practices into a collaborative process to reduce waste and optimize efficiency through all phases of the project life cycle (Glick and Guggemos 2009).

Despite continuous research and development of tools and systems that are capable of resolving the problem of information gaps the construction industry is yet to see remarkable improvement in this regard. Those who have adopted better information systems are finding better results but these benefits are mostly localized. The main reason for partial success is that the use of these integrated information system is piecemeal. In a project team, every organization has different information system, which is based on the functions provided by the organization and the self-motivation of the 
organization in spending for ICT. This high variation does not support seamless flow of information and thus gives little advantage to any organization for using better systems. Especially public sector has been found to rely heavily on the traditional project delivery method, low use of information systems has been found (Azhar, 2005). However, now the future looks significantly different as range of forces are at work: new tools, methodologies and roles; all are influencing and shaping fundamental cultural and business shifts. We stand in the early stages of an accelerating, pervasive and positive transformation.

\subsection{CONSTRUCTION INDUSTRY INSTITUTE'S INFORMATION INTEGRATION} TOOLS

CII has published an implementation resource titled "Information Integration to Improve Capital Project Performance". It presents a set of tools that allows an organization to access its status of information integration and identify a range of information integration opportunities (IOPs) that can also be prioritized and selected for implementation.

The tools, the maturity model and integration opportunity tool are discussed in the following sections. These tools will be reviewed for their strength and weaknesses.

\subsubsection{MATURITY MODEL}

Maturity model serves three purposes (1) assessment of organization's current level of information integration, (2) gap analysis- by comparing the current and desired state of performance, and (3) generation of portfolio of integration opportunities (IOPs). 
It is a set of two models; a general information integration maturity model and a detailed business function information integration maturity model. These models divide the state of information integration into three progressive levels namely;

- Level 1: Business Efficiency (low use of integrated applications and limited understanding of integration opportunities)

- Level 2: Business Effectiveness (integration of internal processes)

- Level 3: Business Transformation (capabilities of seamless exchange of data internally and externally)

\subsubsection{GENERAL INFORMATION INTEGRATION MATURITY MODEL}

This model has two separate matrix representations. First matrix, measures view related to information management, project information strategy, work processes and deliverables, organization culture and performance metrics and data standards against the three levels of information integration defined above. Each level has some defined indicators that help users in determining the existing level of maturity based on the above-mentioned views.

Second matrix helps assessing the status of the organization mapping the firms standing against the statements classified under "You Know you're stuck at this level when..." and "You know you've achieved this level when...." These statements are again arranged according to continuous improvement in level.

The general maturity model can gauge the level of the firm at broader level; however, it is argued that not all business function can be performed at same level. Therefore, a detailed matrix is presented which is discussed below. 


\subsubsection{BUSINESS FUNCTION INFORMATION INTEGRATION MATURITY}

\section{MODEL}

Eight areas or functions are defined based on typical CII member organization operations. Within each business function, its important deliverables are defined. Levels of information integration maturity are developed based on the criteria mentioned before. The resultant is a determination of level of maturity each function is performed.

Next step is to perform a gap analysis, which is a comparison of the existing performance and the desired performance as indicated by the corporate strategy. Identified improvement opportunities, called information integration opportunities (IOPs), are compiled and prioritized during the gap analysis.

\subsubsection{INTEGRATION OPPORTUNITY ASSESSMENT TOOL}

IOP tool is an Excel based tool to facilitate assessment of specific IOPs with respect to large set of benefit drivers (37) and implementation hindrances (34). IOPs can be assessed based on market/legal, organization and process and people/roles/training.

\subsubsection{LIMITATIONS OF THE CII MODEL}

Although the overall approach is systematic but there are several limitations of the model. Firstly, the levels defined for each function are mostly based on industrial large capital projects, which cannot be directly applied to a building project. It is understandable that the tools are developed for CII member companies who are large

owners and contractors but the language limits the use of tool for other kind of construction like building or roads etc. 
The second drawback is that the model doesn't describe how the several deliverables within the same function performed at several levels can be analyzed to give final level for a function. It is not always possible that all deliverables within same business function are performed at the same level therefore the methodology is little unclear in this regard.

\subsection{INFORMATION AND COMMUNICATION TECHNOLOGY (ICT) AND INTEGRATED PROJECT DELIVERY (IPD)}

As argued in the previous section, IPD relies heavily on effective communication and coordination among project participants to achieve project goals. Thus, it is reasonable to assume that the use of information and communication technology (ICT) can foster IPD by facilitating improved communication that is a precondition for effective collaboration.

In fact, several organizations representing different stakeholder groups such as American Institute of Architects (AIA), Associated General Contractors of America (AGC), and National Association of State Facilities Administrator (NASFA) have stated that IPD can be effective with the use of ICT (AIA 2007; AIA and AGC 2011; NASFA et al. 2010). ICT facilitates management of the flow of documents and information within and between organizations (Adriaanse et al. 2010). Fast and reliable information exchange using ICT is necessary among project stakeholders for effective collaboration. Various research studies investigating Building Information Modeling (BIM), a highly developed system of ICT, reported how BIM facilitates IPD (Succar 2009; Sack 2010; Lee et al. 2014). For example, BIM can utilize visualization of form and rapid generation 
of multiple design and construction plan alternatives (Sacks et al. 2010). These technological abilities have the potentials to promote IPD characteristics, such as jointly developed goals and collaborative decision-making.

There have been a number of case studies where the benefits of combined use of IPD and ICT have been reported. According to "Smart Market Report" McGraw-Hill Construction (2012), an IPD team consisting of 11 parties realized significant reduction of rework and higher productivity by using BIM in their medical center project. It was reported that the team achieved substantially lower number of requests for information (RFI) compared to previous projects where IPD and BIM were not used. In another healthcare project using IPD and BIM, Dossick et al. (2013) found that with IPD, the project team was able to establish an "integrated culture" early and then BIM kiosk served as an information hub and contributed to strengthening collaborative norms.

\subsection{CONCEPTUAL FRAMEWORK}

Table 2.2 shows the development of the IPD concept in the context of organizational responses to information need and the levels of integrations (Galbraith 1977). It should be noted that for IPD to work effectively, both the highest level of organizational response, 'coordinating mechanism' and the highest level of integration, 'contractual integration' should exist. Table 2.2 also shows, using bold and italics emphasis, that IPD can be greatly facilitated with a centralized information system, and a decentralized decision-making organizational structure.

Therefore, in order to integrate organizations effectively using information modeling, traditional ways of project delivery must be changed. As any system will 
work best when both medium (Information model) and environment (project delivery system) favor the process of integration. In other words, IPD or integrated project delivery is the result of aligning information infrastructure with organizational structure.

Traditional delivery system embeds short-term thinking on the part of owners who frequently seek the lowest cost for each phase of development, shared contracts that reinforce compartmentalization of team members, rather than support integrated and collaborative efforts (Fallon \& Hagan, 2006, p. 6). Integrated Project Delivery (IPD), on the other hand, is a project delivery approach that integrates people, systems, business structures and practices into a process that collaboratively harnesses the talents and insights of all participants to reduce waste and optimize the whole through all phases of design, fabrication, and construction (AIA 2007).

Table 2.2: IPD in the Context of Organizational Responses and Integrations

\begin{tabular}{|l|l|l|l|}
\hline $\begin{array}{l}\text { Organizational } \\
\text { Response }\end{array}$ & $\begin{array}{l}\text { Informational } \\
\text { Integration }\end{array}$ & $\begin{array}{l}\text { Organizational } \\
\text { Integration }\end{array}$ & $\begin{array}{l}\text { Contractual } \\
\text { Integration }\end{array}$ \\
\hline Reduce Need & $\begin{array}{l}\text { Avoid duplication, } \\
\text { Centralize information } \\
\text { system }\end{array}$ & $\begin{array}{l}\text { Eliminate middle layer, } \\
\text { Develop virtual organizations }\end{array}$ & $\begin{array}{l}\text { De-emphasize } \\
\text { Bureaucracy, Emphasize } \\
\text { goartnering agreements } \\
\text { partevelop }\end{array}$ \\
$\begin{array}{l}\text { Increase } \\
\text { Capacity }\end{array}$ & $\begin{array}{l}\text { Add resources, } \\
\text { Invest in information } \\
\text { systems infrastructure }\end{array}$ & $\begin{array}{l}\text { Decentralize decision- } \\
\text { making authorities, } \\
\text { Empower managers with } \\
\text { information, not hierarchy }\end{array}$ & $\begin{array}{l}\text { Develop e-commerce, e- } \\
\text { business capabilities }\end{array}$ \\
\hline $\begin{array}{l}\text { Implement } \\
\text { Coordinating } \\
\text { Mechanism }\end{array}$ & $\begin{array}{l}\text { Improve consistency } \\
\text { and uniformity of } \\
\text { information, } \\
\text { Introduce common } \\
\text { systems }\end{array}$ & $\begin{array}{l}\text { Combine units, functions } \\
\text { (e.g. design-build), Develop } \\
\text { joint ventures }\end{array}$ & $\begin{array}{l}\text { Implement Integrated } \\
\text { Project Delivery }\end{array}$ \\
\hline
\end{tabular}




\subsection{CHAPTER SUMMARY}

A thorough review of literature on several aspects of research conducted in this dissertation is provided in this chapter. The purpose was to present a detailed and clear understanding of the principles and establishment of the foundation of the research. As mentioned earlier, very few studies have been conducted on the IPD-ICT relationship from the perspective provided in this research. One of the most important outcomes of this literature review is the conceptual framework presented in section 2.8 . The literature review further guided in conducting the public owners' survey, presented in Chapter 4. 


\section{CHAPTER-3: RESEARCH METHODOLOGY}

\subsection{INTRODUCTION}

As mentioned earlier the research questions presented in this dissertation, have not been investigated previously. In this chapter, the research methodology developed for seeking answers to the research questions is described. In addition, an IPD readiness assessment model has been developed and implemented as a part of this methodology. The model is designed to give a set of recommendations as outcomes to an owner organization.

Figure 3.1 shows the major components of the methodology. Following subsections provide the details of each component.

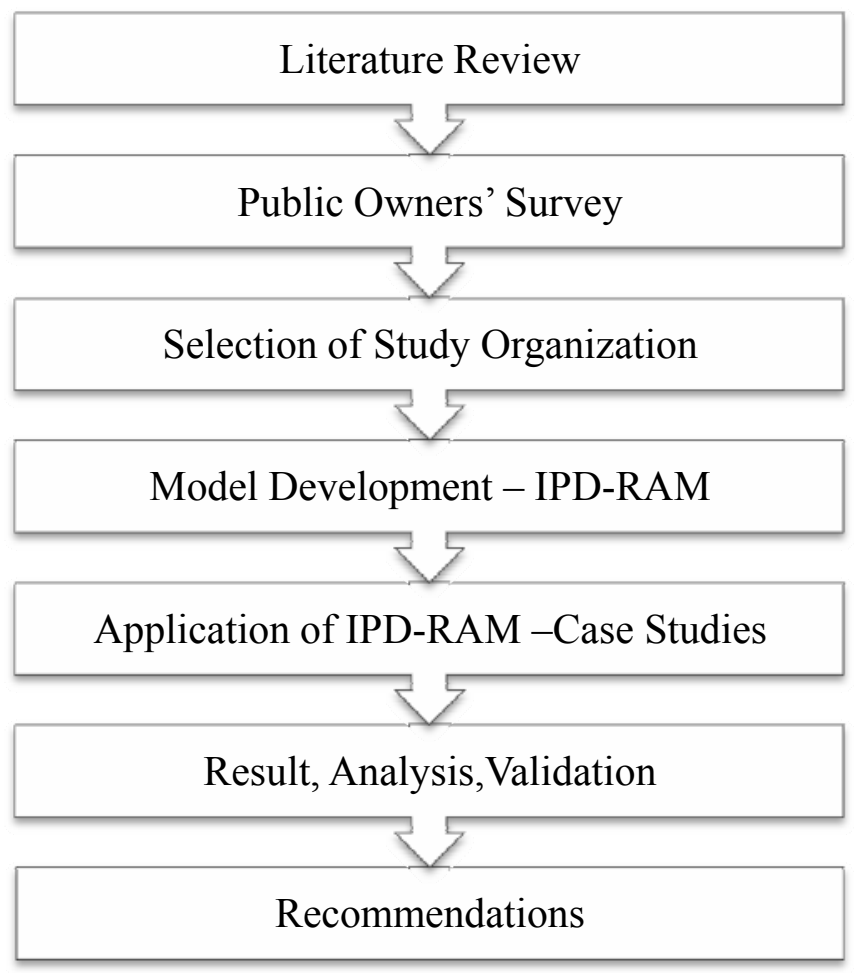

Figure 3.2: Research Methodology 


\subsection{LITERATURE REVIEW}

A thorough literature review was conducted for clear understanding of the principles and establishment of the foundation of the research. As mentioned earlier, not many studies were found on the IPD-ICT relationship from the perspective used in this research. The major outcome of the literature review is a conceptual framework that places IPD in the context of organizational responses and integrations.

\subsection{PUBLIC OWNERS SURVEY}

In this stage of the research study, existing condition of the US public owner organizations were assessed regarding their practice of project delivery systems and the nature of their use of information and communication technologies (ICT). In order to accomplish this task, an on-line survey was conducted among public owner organizations in the US. The survey was distributed electronically through e-mails to 220 public sector owners. Their contact information was obtained through official websites. 138 organizations responded to the survey, 59 of which were found complete and usable.

The survey consists of three sections (see Appendix A). The first section asks organizational profiles such as organization type (i.e., local government, state government, etc.), type of typical projects, and organization size in terms of number of employees and annual construction capital spending. The second section is about project delivery system currently used. It asks the typical project delivery system being used in the organization, and their impacts on different parameters such as project budget and duration. This section also asks the impact of IPD characteristics on the effectiveness of project delivery system as shown in (Question 15 - Appendix A). The term Integrated 
Project Delivery or IPD was not introduced in the survey intentionally for the following reason. There has been no standard IPD definition accepted by the industry at large (Kent and Becerik-Gerber 2010). The AIA's definition of IPD mentioned previously has been widely used in many studies (Ilozor and Kelly 2012; Nawari 2012; Succar 2009). However, the terms such as "IPD-ish" and "IPD-lite", focusing mainly on the collaboration without the use of a multiparty contract (MC), are also quite common in the construction industry (El Asmar et al. 2013; NASFA et al. 2010; Wickersham 2009). Considering the fact that a standard definition of IPD is nonexistent, researcher refrained from using the term IPD in the survey. Rather, the responses were sought on the six IPD characteristics, which were briefly introduced in the survey questionnaire (See Question 15- Appendix A).

The third section of the survey asks questions on the practice of information and communication exchange. In order to measure the degree of ICT use, the survey asks the percentage of electronic transmittal of some documents as shown in question 17 of Appendix A. In addition to these questions, one question directly asks if the use of ICT fosters the IPD characteristics (Question 18-Appendix A).

\subsection{SELECTION OF THE STUDY ORGANIZATION}

FIU Facilities Management Department, a local public owner organization was selected for this research study. The organization is routinely involved in capital projects using various delivery methods. Information and data were collected for six projects from the organization. The designated personnel from the organization formed the focus group 
that was consulted for feedback throughout the model development phases and also for the validation of the model and its application.

\subsection{DEVELOPMENT OF IPD-RAM}

Based on the findings of literature review and survey results, an Integrated Project Delivery Readiness Assessment Model (IPD-RAM) was developed for assessing the public owner organizations in the U.S. This stage involved a thorough review of analytical techniques and discussions with the area experts. The model was designed with a goal to determine IPD "readiness" of a public owner organization considering selected IPD principles, and "ICT levels," at which project functions are carried out.

IPD readiness measuring scales were developed for each of the selected IPD principles. These scale measures the readiness related particular IPD principle based on several dimensions of the specific IPD principle on a scale of 0 to 10 . Where 0 (zero) means that project is not IPD ready and 10 means project is fully IPD ready for the IPD principle in question. Three transitional points i.e. 2.5, 5 and 7.5 were also described in detail.

For defining ICT levels, major project functions were identified for each of the selected project phase. Three progressively increasing ICT levels were designated based on the several alternative means and methods that can be adopted to perform that particular project function. Relationship between project functions and IPD principles were then determined. IPD readiness and ICT level of each IPD principle were connected and can be mapped through project functions. 


\subsection{APPLICATION OF IPD-RAM}

The model developed was then applied in six case projects, all done under the selected public owner organization (FIU). As mentioned in the previous stage, this stage required a thorough review of project data. For each case project, the project information was collected through several means. The first source of data was project files for each project that are maintained by FIU. Secondly, information was collected through interviews of the project managers and other representatives of owners, $\mathrm{A} / \mathrm{Es}$ and contractors that were responsible for managing those projects. Electronic records of information were also obtained for records like RFIs logs, BIM execution plan, etc. Several telephonic and email communications were made with the project members to find the information needed.

The outcome of the application was the IPD readiness score for each of the ten selected IPD principles and level of ICT for twenty defined project functions at several stages of construction. Input and feedback were obtained from the "focus group" on the model and its applications.

\subsection{RESULTS, ANALYSIS, VALIDATION}

The results of the IPD-RAM application were then utilized to identify the opportunities to improve IPD. ICT tools and methods were identified for selected project functions. The levels were determined, at which these tools and methods were used. A critical examination and analysis were carried out to identify ICT opportunities that have the potentials to improve IPD implementation. Pair-wise comparisons between case study projects were carried out in this step. The process is expanded to comparison 
of an "ideal" high IPD project to real case projects. The detailed analysis of the outcomes resulted in identification of gaps indicating specific ICT implementation opportunities that would result in improvement of IPD readiness of the organization. This has resulted in specific ICT recommendations for the owner organization.

The validation was conducted in two tiers. In the first tier, a focus group was formed with the members from the case study organization. The feedback from the focus group were sought and utilized throughout the development and implementation of the model. The focus group input was very helpful for validation of the model and its results.

Secondly, the model was presented to a group of experts from the industries that were selected based on their experience with IPD, ICT and the public sector. These experts were interviewed using a semi-structured interview approach and their feedback was received on several aspects of the model and its ability to measure IPD- readiness of public owner organizations.

\subsubsection{VALIDATION THROUGH FOCUS GROUP}

Ogunlana et al. (2003) stated three different ways the consequences of aspects like policy change, shift in organization strategies or effects of new information system implementation, etc. can be studied or investigated in an organization. The first option he presented is to implement the changes on an organization on experimental basis and study the effects. This is very similar to what is known as action research (Azhar et al. 2009). The second option is to develop a dynamic simulation model of the organization (such as using System Dynamics concept) and investigate the effects of different factors. 
The third option is to form a focus group consisting of organization executives and discuss possible future scenarios using their experience and gut-feelings. While the first option was not feasible in this research as it requires actual investment in terms of money, time and willingness of the organization executives to perform the experiment, second option was also infeasible as most of the factors considered are of qualitative nature (collaborative and behavioral) that are not suitable for systems simulation study. Focus group was found to be the most practical option given the scope of this research study. As mentioned later in section 5.2 the focus group was s involved in the early stages of this research during model development. This involvement allowed the focus group to better understand the model and be able to offer their opinions at the validation stage.

\subsubsection{MODEL VALIDATION THROUGH FIELD EXPERTS}

As discussed above, the model was also presented to a group of experts (not the focus group) and their feedback was obtained. The criteria for selecting experts were stringent to ensure the value of feedback. First the basic web search was conducted to identify the list of experts in the field of IPD and construction ICT. From the first list personnel with at least 25 years of relevant experience were shortlisted. Profiles of the experts were also searched for relevant publications, association, and participation of the experts with major construction industry organizations such as American Institute of Architects (AIA), Construction Owners Association of America (COAA), Construction Management Association of America (CMAA) and Associated General Contractors of America (AGC). The shortlisted experts were contacted through business-oriented social 
networking service LinkedIn. The brief abstract of the research was presented to the experts and they were requested to serve as an expert in the research study. A round of communications took place between the researcher and experts in order to fully explain the aims and objectives of research and expectations from expert input and feedback. Experts were provided with more detailed documents related to the model. Initially seven experts agreed to participate in the research. These experts were physically scattered throughout US. Therefore, it was decided to collect their feedback through telephonic interviews. Five experts were available during the timeframe set for conducting interviews and became part of this research.

Semi-structured interviews were conducted based on the list of topics that were developed by the researcher to cover all the major themes of the model. Appendix B contains the list of questions that were put forward to the experts. Also, experts were encouraged to comment on the overall research concept. The duration of interview varied from 30 minutes to 75 minutes. All interviews were recorded and transcribed later for analysis.

\subsection{RECOMMENDATIONS}

The results of the model were analyzed as described to develop a set of recommendations for the owner organization. Three sets of recommendations were suggested based on informational, organizational and contractual perspectives of IPD readiness. These recommendations can serve as the basis for strategy formulation by the organization so that it can focus on certain IPD principles and can determine which ICT tools and methods it should invest in, and what organizational changes it should 
implement. The result obtained from the IPD-RAM model should also point to the specific contractual regulations and procurement rules that are in the way to achieve higher IPD readiness by taking full advantage of available ICT tools and methods.

\subsection{CHAPTER SUMMARY}

The steps followed in the research study are presented in this chapter. The first step, literature review has already been presented in Chapter 2. The literature review provided guidance in developing the public owners' survey to establish state-of -the practice of IPD, ICT, and to analyze the IPD-ICT relationship through statistical techniques, as detailed in the next chapter (Chapter 4). . 


\section{CHAPTER-4: PUBLIC OWNERS SURVEY}

\subsection{INTRODUCTION}

This chapter provides an assessment of the state-of-the practice of project delivery systems and the nature of use of information and communication technologies (ICT) in public owner organizations. This survey was conducted to investigate the relationship between IPD and ICT taking the degree or extent of ICT use and the type of ICT (internal versus external) into consideration.

\subsection{QUESTIONNAIRE SURVEY}

\subsubsection{DESIGN}

An online questionnaire using Qualtrics ${ }^{\mathrm{TM}}$ was developed. The questionnaire is attached in Appendix A. It was carefully designed to avoid confusions and ambiguities with technical terms and abbreviations. It consisted of three sections. In the first section questions regarding the organizational profile, such as, organization type (i.e., local government, state government, etc.), type of typical projects, and organization size in terms of number of employees and annual construction capital spending, were asked. The second section was regarding project delivery system being used. It included questions regarding typical project delivery systems the organization has experience with, and their impacts on various parameters such as project budget and duration. Also presented in this section is an assessment of the impact of IPD characteristics on the effectiveness of project delivery system.

The third section of the survey asked questions on the practice of information and communication exchange. In order to measure the degree and type of ICT use, questions 
concerning the percentage of electronic transmittal of documents, and the type of ICT use were included. In addition to these questions, one question directly asked if the use of ICT fosters the IPD characteristics, without using the term IPD but only mentioning the six characteristics as explained below.

\subsubsection{SAMPLING}

The survey was distributed electronically through e-mails to 220 public sector owners. Their contact information was obtained through official websites. 59 complete and usable were received and were made part of analysis.

\subsection{SURVEY RESULTS AND ANALYSIS}

As mentioned earlier, the questionnaire was divided into three sections. The responses for Section A (i.e., organizational profile) was analyzed through descriptive analysis to report the general characteristics and profile of the respondent organizations through graphs, charts and tables. Section B (project delivery) was analyzed through descriptive analysis to report the state-of-the-practice of the respondent organizations regarding current project delivery practices through graphs, charts and tables. While the responses from questions in section C (i.e. information and communication exchange) and question 15 , were analyzed statistically through inferential analysis to provide a critical look into relationship between ICT and IPD in public sector construction. Details on findings from the survey analysis are provided in the following subsections. 


\subsubsection{ORGANIZATIONAL PROFILE}

\subsubsection{ORGANIZATION TYPE}

The public owner organizations were broadly divided into four types, i.e. local government, state government, federal government and educational institution. Figure 4.1 provides a breakdown of the valid responses by organization type. It indicates that 30 (51\%) respondents were local government organizations, 23 (39\%) were state government organizations, $6(10 \%)$ were educational institutions.

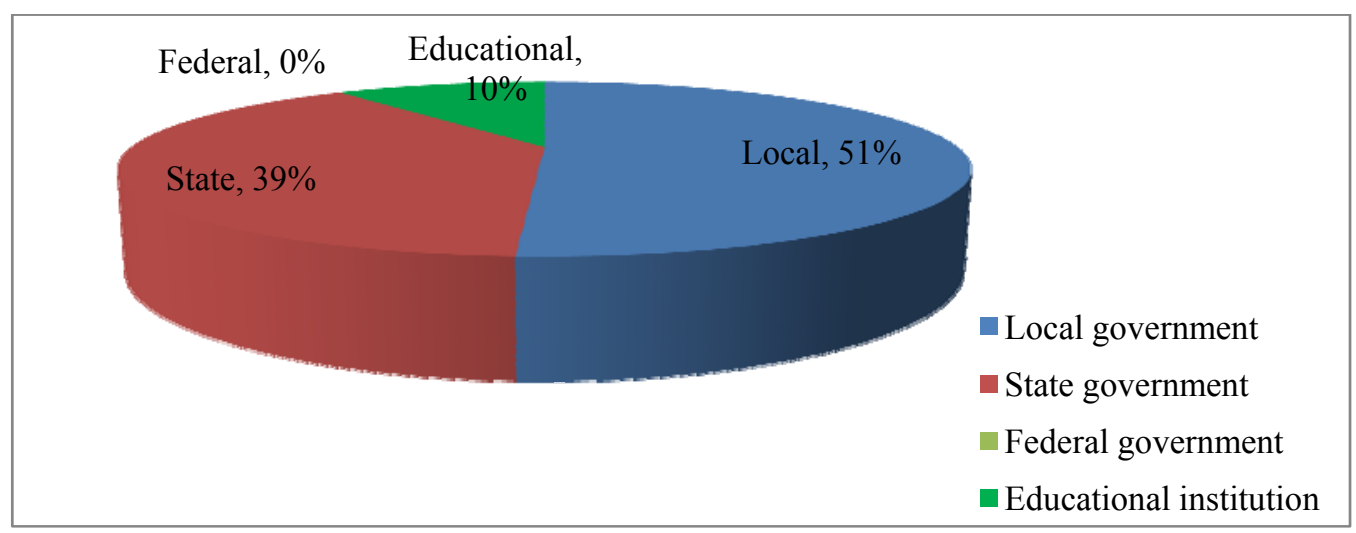

Figure 4.1: Respondent Organization Type

\subsubsection{TYPE AND NUMBER OF CONSTRUCTION PROJECTS}

The responding organizations has undertaken all types of construction projects that public organizations usually perform ranging from office buildings to infrastructure development and public works. Each organization was typically found to work in two or three different type of construction projects depending on the nature of organization. Figure 4.2 illustrates the number of organizations involved with each type of construction project. 
Figure 4.3 shows the breakdown of number of projects undertaken by each organization in a typical year. It indicates that more than one-third organizations (36\%) undertake 50 or more projects in a typical year. However the number of projects also depends on the type of organization, public works organization tend to do more projects with relatively smaller scopes as compared to organizations involved with mega projects such as mass-transit, port development etc.

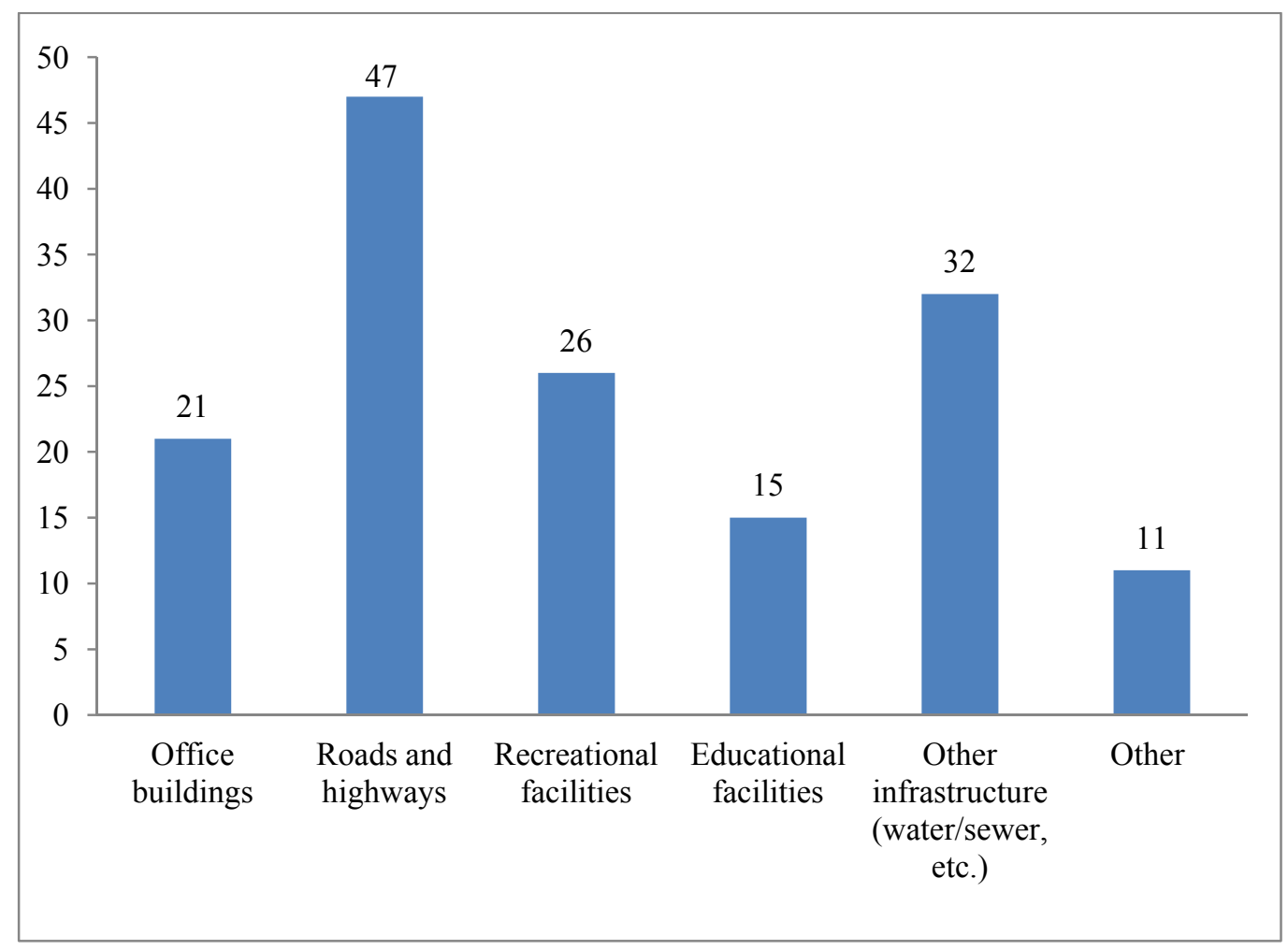

Figure 4.2: Types of Construction Projects Undertaken by Respondent Organizations

Concisely, this information points out that the responding organizations are involved in all types and sizes of construction projects and data collected from them represents the public sector as a whole. 


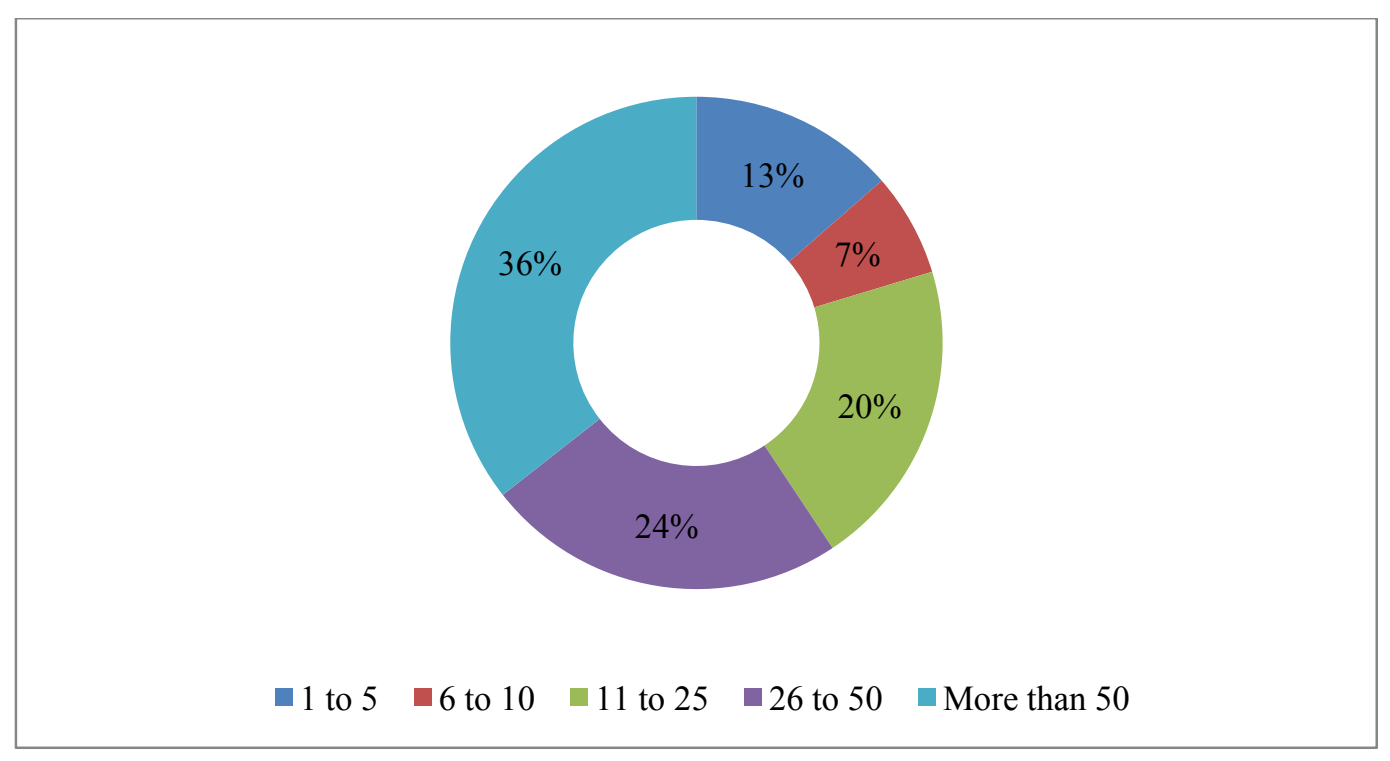

Figure 4.3: Number of Projects Undertaken by the Organization Annually

\subsubsection{ORGANIZATION SIZE AND ANNUAL CONSTRUCTION EXPENDITURE}

Figure 4.4 and 4.5 provide details about the respondent organizationslunits in term of their number of employees (technical staff) and the annual construction expenditure. Out of 59 valid responses, received $37 \%$ organizations/units had number of employees between 1 to 25 and another $37 \%$ organization had employees greater than 100. Further analysis revealed that majority of state government organizations $(69 \%)$ had greater than 100 employees. While majority of educational institutions (84\%) and almost half of the local government organizations had less than 25 employees. In terms of annual construction expenditure, there was no unique trend except that no organization mentioned an annual construction expenditure of less than $\$ 1$ million. Among other five categories of expenditure ranging from $\$ 1$ million to greater than $\$ 500$ million, each category got around one-fifth (i.e. $20 \%$ ) of total share. This indicates that the sample consisted of a mix of small, medium and large public owner organizations. 


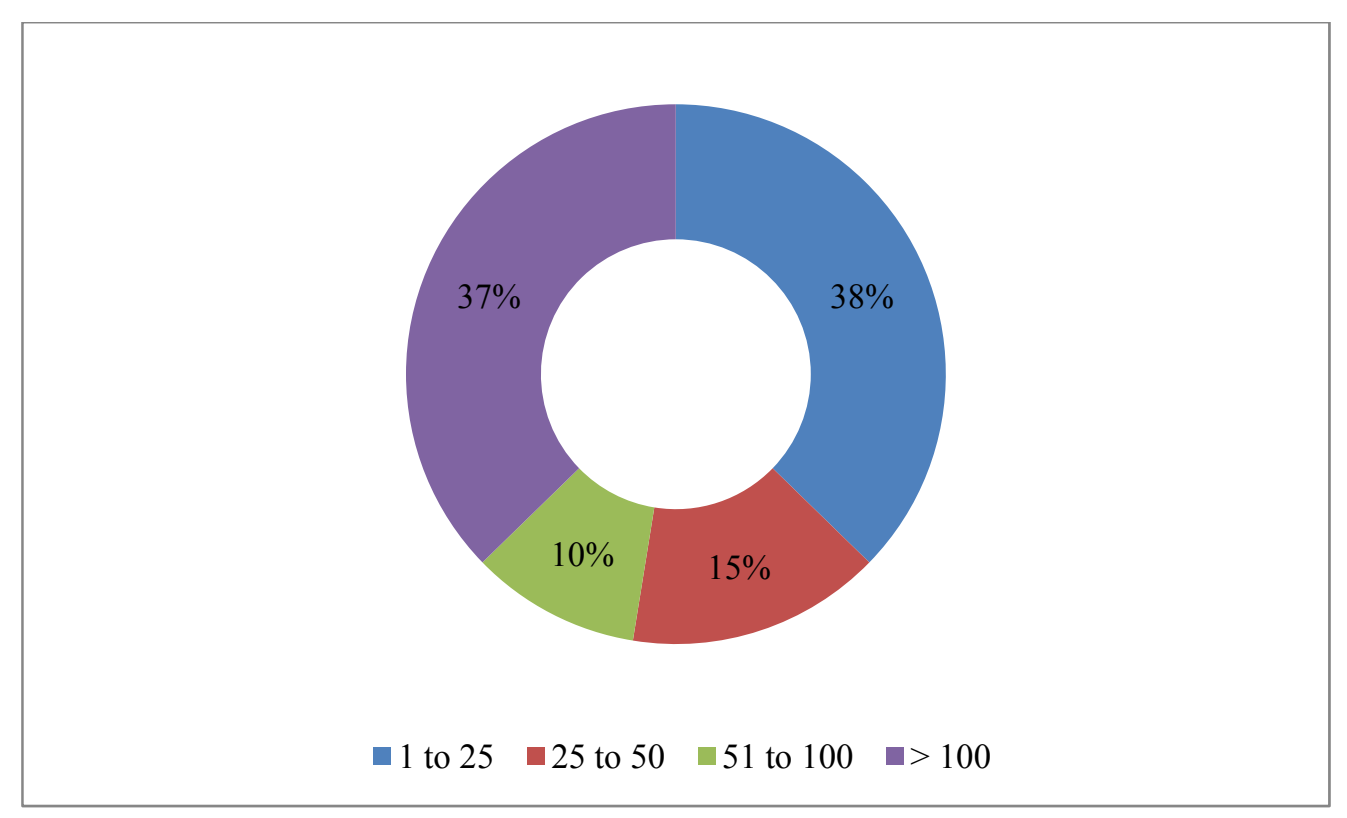

Figure 4.4: Organization or Unit Size by Number of Employees

\subsubsection{IN-HOUSE/OUTSOURCED ACTIVITIES}

Table 4.1 provides the summary of organization practices of in-house to outsourced worked practices. It can be observed that majority of organizations tend to have in-house professionals to do the initial planning. No precise patterns were found for design and development of specifications, estimating and budgeting and value engineering. Construction is generally outsourced and operation and maintenance are done in-house for the majority of organizations.

\subsubsection{EXISTENCE OF IT DEPARTMENT TO ASSIST CONSTRUCTION PROJECTS.}

Figure 4.6 and 4.7 provides the summary of presence of IT department/units within the public owner organizations to assist construction projects performed by the organization. Figure 6 shows that $95 \%$ of the respondent organizations has IT 
departments and for about two-third of the respondents these departments are there for more than 15 years.

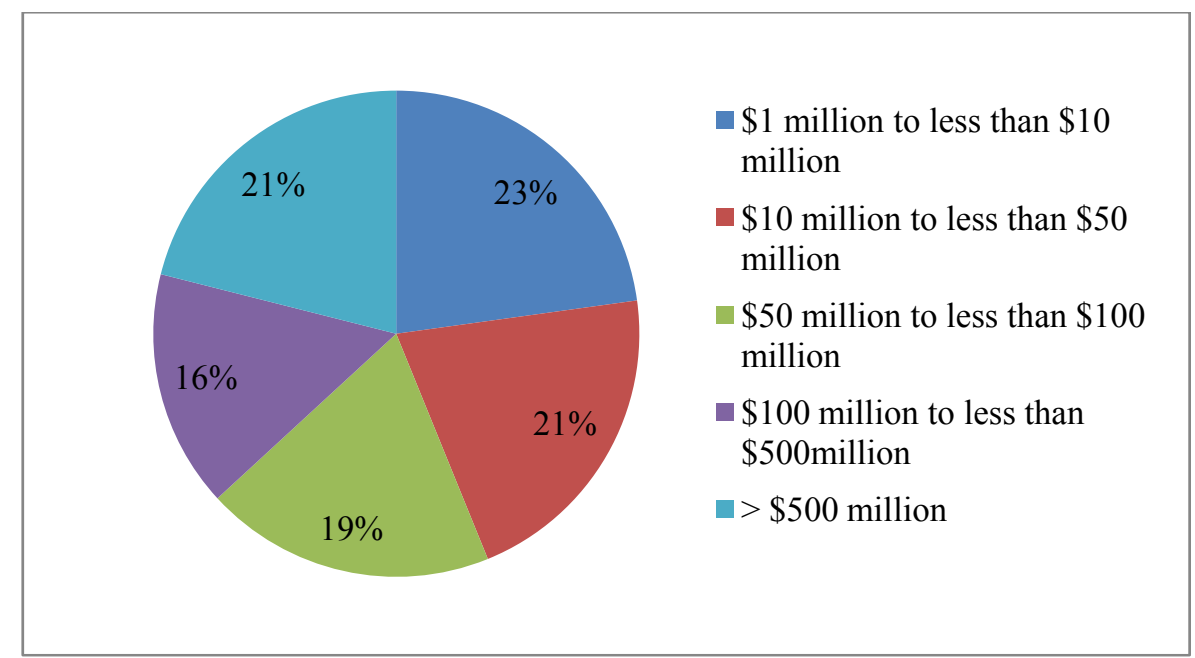

Figure 4.5: Annual Construction Expenditure of Organization Surveyed

Table 4.1: In-House / Outsourcing Practices of Organizations

\begin{tabular}{|l|c|c|c|c|c|}
\hline & \multicolumn{3}{|c|}{ In-house - - -------ourced } \\
\hline Project Stages & $\mathbf{1 0 0 / 0} \%$ & $\mathbf{7 5 / 2 5} \%$ & $\mathbf{5 0 / 5 0} \%$ & $\mathbf{2 5 / 7 5} \%$ & $\mathbf{0 / 1 0 0} \%$ \\
\hline Initial planning (feasibility study) & $25 \%$ & $32 \%$ & $18 \%$ & $19 \%$ & $7 \%$ \\
\hline Design and development of specifications & $2 \%$ & $25 \%$ & $26 \%$ & $25 \%$ & $23 \%$ \\
\hline Estimating and budgeting & $18 \%$ & $26 \%$ & $28 \%$ & $23 \%$ & $5 \%$ \\
\hline Value engineering & $16 \%$ & $16 \%$ & $25 \%$ & $33 \%$ & $11 \%$ \\
\hline Construction & $7 \%$ & $11 \%$ & $4 \%$ & $25 \%$ & $54 \%$ \\
\hline Operation and maintenance & $51 \%$ & $28 \%$ & $9 \%$ & $5 \%$ & $7 \%$ \\
\hline
\end{tabular}

\subsubsection{PROJECT DELIVERY PRACTICES IN PUBLIC CONSTRUCTION SECTOR}

\subsubsection{COMMONLY USED DELIVERY SYSTEMS}

Figure 4.8 shows the distribution of project delivery methods among the respondent organizations. It shows that Design -bid - build (DBB) is still the most used 
project delivery method in public sector projects. $65 \%$ of the respondents replied that DBB was used to delivery greater than $80 \%$ of the projects and another $17 \%$ indicated that it is been used for delivering $50-80 \%$ of the projects. No other project delivery method including DB showed any significant usage in the public projects.

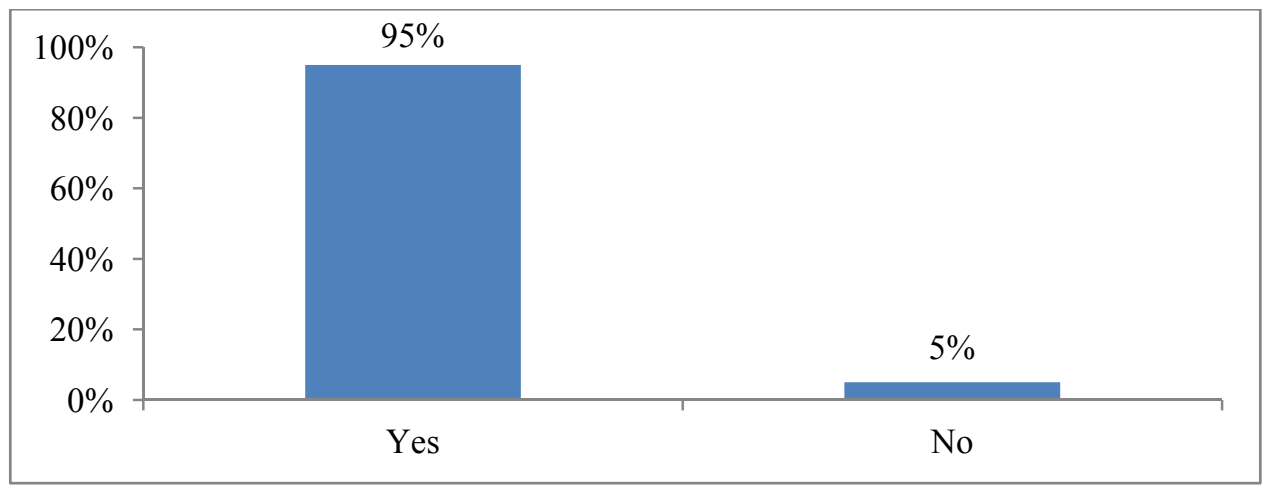

Figure 4.6: IT Department to Assist Construction Projects

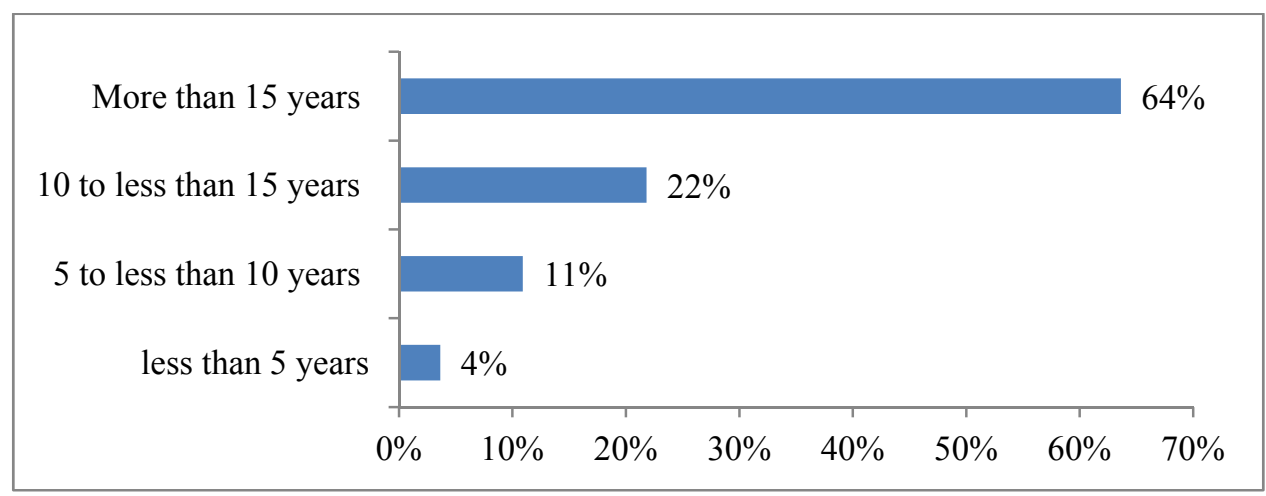

Figure 4.7: Age of IT Department

\subsubsection{PROJECT FACTORS INFLUENCING DELIVERY METHOD SELECTION}

To analyze the influencing effect of several project related factors on the selection of project delivery system, respondents were asked to rate the factors as significant, somewhat significant or not significant. Following tables $4.2-4.4$ represents the 
respondent's replies to the factors of project budget, project duration, design/specifications, project risk, procurement/Acquisition regulations, and information/communication needs of project that they consider significant for the selection of several delivery systems.

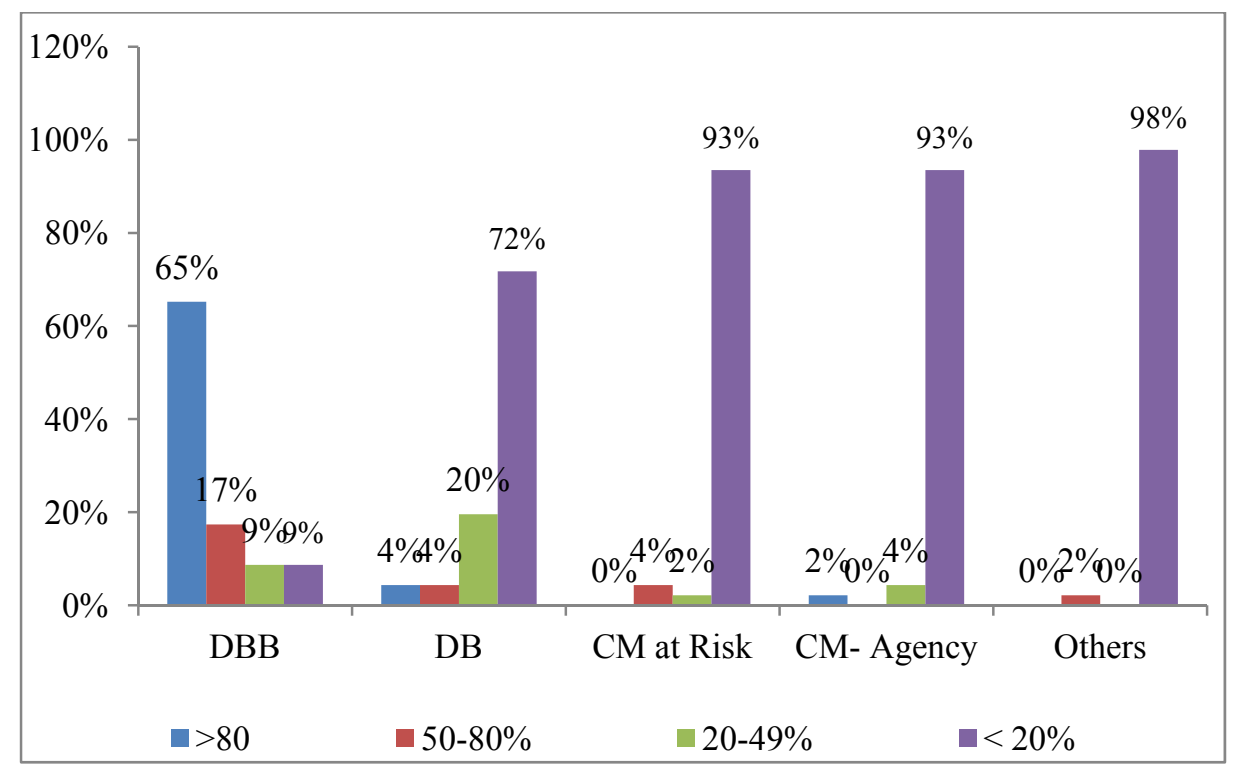

Figure 4.8: Distribution of Project Delivery Methods

Table 4.2: Significant Factors of Project Delivery Method Selection

\begin{tabular}{|l|c|c|c|c|c|c|}
\hline $\begin{array}{c}\text { Project } \\
\text { Delivery } \\
\text { Method }\end{array}$ & $\begin{array}{c}\text { Project } \\
\text { budget }\end{array}$ & $\begin{array}{c}\text { Project } \\
\text { Duration }\end{array}$ & $\begin{array}{c}\text { Design } \\
\text { /Specifications }\end{array}$ & $\begin{array}{c}\text { Project } \\
\text { Risk }\end{array}$ & $\begin{array}{c}\text { Procurement } \\
\text { /Acquisition } \\
\text { Regulations }\end{array}$ & $\begin{array}{c}\text { ICT needs } \\
\text { of project }\end{array}$ \\
\hline DBB & $51 \%$ & $35 \%$ & $52 \%$ & $37 \%$ & $49 \%$ & $30 \%$ \\
\hline DB & $28 \%$ & $53 \%$ & $44 \%$ & $55 \%$ & $60 \%$ & $30 \%$ \\
\hline CM at risk & $36 \%$ & $36 \%$ & $35 \%$ & $45 \%$ & $50 \%$ & $25 \%$ \\
\hline $\begin{array}{l}\text { CM } \\
\text { agency }\end{array}$ & $38 \%$ & $33 \%$ & $35 \%$ & $18 \%$ & $39 \%$ & $17 \%$ \\
\hline
\end{tabular}

For the projects for which DBB was selected as an option, $51 \%$ of the respondents said that project budget was the significant factor for decision, similarly design /specifications (52\%) and procurement / acquisition regulations (49\%) were ranked high 
as the significant factors for selection of $\mathrm{DBB}$ on the construction project. For DB, project duration (53\%), project risk $(55 \%)$ and procurement / acquisition regulations $(60 \%)$ were ranked significant factors of decision of selection. For CM at Risk $50 \%$ of responded indicated that procurement / acquisition regulations is the deriving factor of selection.

It can be said based on results presented in Table 2, which for selection of any project delivery system, the factor of procurement / acquisition regulations is very important. It means that, for considering any project delivery option, prevailing laws and regulation plays an important role. Other project success related factors such as project budget, project duration etc are considered only when that delivery system passes the test of being "allowed" delivery system for doing the project.

Table 4.3: Somewhat Significant Factors of Project Delivery Method Selection

\begin{tabular}{|l|c|c|c|c|c|c|}
\hline $\begin{array}{c}\text { Project } \\
\text { Delivery } \\
\text { Method }\end{array}$ & $\begin{array}{c}\text { Project } \\
\text { budget }\end{array}$ & $\begin{array}{c}\text { Project } \\
\text { Duration }\end{array}$ & $\begin{array}{c}\text { Design/ } \\
\text { Specifications }\end{array}$ & $\begin{array}{c}\text { Project } \\
\text { Risk }\end{array}$ & $\begin{array}{c}\text { Procurement } \\
\text { /Acquisition } \\
\text { Regulations }\end{array}$ & $\begin{array}{c}\text { ICT needs } \\
\text { of project }\end{array}$ \\
\hline DBB & $31 \%$ & $44 \%$ & $31 \%$ & $39 \%$ & $35 \%$ & $42 \%$ \\
\hline DB & $42 \%$ & $24 \%$ & $26 \%$ & $27 \%$ & $21 \%$ & $36 \%$ \\
\hline CM at risk & $23 \%$ & $26 \%$ & $32 \%$ & $26 \%$ & $25 \%$ & $38 \%$ \\
\hline $\begin{array}{l}\text { CM } \\
\text { agency }\end{array}$ & $19 \%$ & $23 \%$ & $26 \%$ & $50 \%$ & $32 \%$ & $37 \%$ \\
\hline
\end{tabular}

Table 4.3 similarly shows the results of factors regarded as somewhat significant for making the project delivery system selection decision respectively. It can be noted that information and communication needs are ranked by considerable respondents as somewhat significant for almost all type of project delivery systems. For DBB, along with the information and communication needs, Project duration (44\%) is considered as 
somewhat significant, for DB Project budget (42\%) is considered. Similarly, for CM at risk, Design specifications (32\%) and Project Risk (50\%) for CM- agency are indicated as somewhat significant for the project delivery selection process.

Table 4.4: Not Significant Factors of Project Delivery Method Selection

\begin{tabular}{|l|c|c|c|c|c|c|}
\hline $\begin{array}{c}\text { Project Delivery } \\
\text { Method }\end{array}$ & $\begin{array}{c}\text { Project } \\
\text { budget }\end{array}$ & $\begin{array}{c}\text { Project } \\
\text { Duration }\end{array}$ & $\begin{array}{c}\text { Design/ } \\
\text { Specifications }\end{array}$ & $\begin{array}{c}\text { Project } \\
\text { Risk }\end{array}$ & $\begin{array}{c}\text { Procurement } \\
\text { /Acquisition } \\
\text { Regulations }\end{array}$ & $\begin{array}{c}\text { ICT needs } \\
\text { of project }\end{array}$ \\
\hline DBB & $18 \%$ & $21 \%$ & $17 \%$ & $24 \%$ & $16 \%$ & $28 \%$ \\
\hline DB & $30 \%$ & $22 \%$ & $30 \%$ & $18 \%$ & $19 \%$ & $34 \%$ \\
\hline CM at risk & $41 \%$ & $38 \%$ & $32 \%$ & $29 \%$ & $25 \%$ & $38 \%$ \\
\hline CM - agency & $44 \%$ & $43 \%$ & $39 \%$ & $32 \%$ & $29 \%$ & $47 \%$ \\
\hline
\end{tabular}

Relatively lower percentages for influencing factors are indicated as not significant for all the listed factors in Table 4.4 for DBB. For DB almost equal number of respondents $(34 \%)$ regarded information and communication needs as not a significant factor. A reason for this might be the reduced need of information communication between the design and construction professionals as compared to the traditional delivery system as here in this case both design and construction function reside in the same organization. For $\mathrm{CM}$ at risk and $\mathrm{CM}$ - agency, the analysis result shows higher percentages for almost all factors in discussion as not significant.

\subsubsection{INFLUENCE OF CONTRACT TYPE OF PROJECT DELIVERY METHOD}

Table 4.5- 4.7 represents the influence of the following contract types; lump sum, cost-plus, unit price, and guaranteed maximum price (GMP) on the project delivery selection on the decision of delivery method for public project. Same scale of influence i.e. significant, somewhat significant and not significant was used to judge the influence. 
Table 4.5: Significant Contract Types for Project Delivery Method Selection

\begin{tabular}{|l|c|c|c|c|}
\hline $\begin{array}{c}\text { Project Delivery } \\
\text { Method }\end{array}$ & $\begin{array}{c}\text { Lump } \\
\text { Sum }\end{array}$ & Cost Plus & $\begin{array}{c}\text { Guaranteed Maximum } \\
\text { Price }\end{array}$ & Unit Price \\
\hline Design/bid/build & $39 \%$ & $20 \%$ & $26 \%$ & $61 \%$ \\
\hline Design/build & $51 \%$ & $23 \%$ & $44 \%$ & $28 \%$ \\
\hline CM at risk & $39 \%$ & $24 \%$ & $59 \%$ & $21 \%$ \\
\hline CM - agency & $31 \%$ & $13 \%$ & $35 \%$ & $23 \%$ \\
\hline
\end{tabular}

For the projects where contract type is Unit Price (61\%), DBB is regarded as most viable option for project delivery. Similarly most significant contract type for selection of DB as a delivery method is indicated as Lump sum. GMP (44\%) was also regarded as significant in case of DB. For selection CM at Risk and CM- agency again GMP (59\%, $35 \%$ ) was regarded as significant contract type. This result is logical as GMP is the one of the basis of CM delivery systems where Construction manager that serves as the consultant of owner at the earlier stages of project agrees to provide construction services for the project at GMP. These and rest of distributions for significant contract types can be seen in Table 4.5 .

Table 4.6: Somewhat Significant Contract Types for Project Delivery Method Selection

\begin{tabular}{|l|c|c|c|c|}
\hline $\begin{array}{c}\text { Project Delivery } \\
\text { Method }\end{array}$ & $\begin{array}{c}\text { Lump } \\
\text { Sum }\end{array}$ & Cost Plus & $\begin{array}{c}\text { Guaranteed } \\
\text { Maximum Price }\end{array}$ & Unit Price \\
\hline Design/bid/build & $30 \%$ & $22 \%$ & $31 \%$ & $22 \%$ \\
\hline Design/build & $20 \%$ & $23 \%$ & $18 \%$ & $30 \%$ \\
\hline CM at risk & $29 \%$ & $24 \%$ & $10 \%$ & $29 \%$ \\
\hline CM - agency & $24 \%$ & $33 \%$ & $17 \%$ & $26 \%$ \\
\hline
\end{tabular}

Contract types that are regarded as somewhat significant for selection of a particular delivery system are represented in Table 4.6. Another 30\% respondents regarded Lump sum for DBB along with GMP (31\%) under this categorization. Similarly Unit price (30\%) for selecting DB, lump sum and unit price (29\%) for CM at risk and 
Cost Plus (33\%) for CM-agency were identified by the respondents.

Table 4.7: Not Significant Contract Types for Project Delivery Method Selection

\begin{tabular}{|l|c|c|c|c|}
\hline & $\begin{array}{c}\text { Lump } \\
\text { Sum }\end{array}$ & Cost Plus & $\begin{array}{c}\text { Guaranteed } \\
\text { Maximum Price }\end{array}$ & Unit Price \\
\hline Design/bid/build & $30 \%$ & $58 \%$ & $43 \%$ & $16 \%$ \\
\hline Design/build & $29 \%$ & $55 \%$ & $38 \%$ & $42 \%$ \\
\hline CM at risk & $32 \%$ & $51 \%$ & $31 \%$ & $50 \%$ \\
\hline CM - agency & $45 \%$ & $53 \%$ & $48 \%$ & $52 \%$ \\
\hline
\end{tabular}

High magnitudes for Cost plus (58\%) and GMP (43\%) for DBB as being not significant for selection again strengthen the fact that combination of Unit price and DBB is more preferred. Similarly, all the responses for not significant contract types are numerated in Table 4.7.

\subsubsection{PROJECT PERFORMANCE UNDER CURRENT PROJECT DELIVERY OPTIONS}

To evaluate the performance of the project on project budget, project cost and project quality front, respondents were asked to indicate the approximate classification (in \%) of organization's projects performance under the heads of budget, cost and quality of the projects completed in the recent past by the organization.

Figure 4.9 shows the distribution of responses for the performance of projects on budget front. It can be noted that high percentage of respondents $(76.5 \%)$ indicated that $20 \%$ or less of the projects performed by their organizations are over usually over budget. A similar pattern can be seen for under budget percentage, where $60.8 \%$ of respondents indicated that only $20 \%$ or less of their projects are under budget. This indicates that majority of the projects performed by these organizations meet their planned budget. This 
is also indicated by high number of respondents (cumulatively 60\%) regarding their project as "on budget" for 61 or more percent of projects.

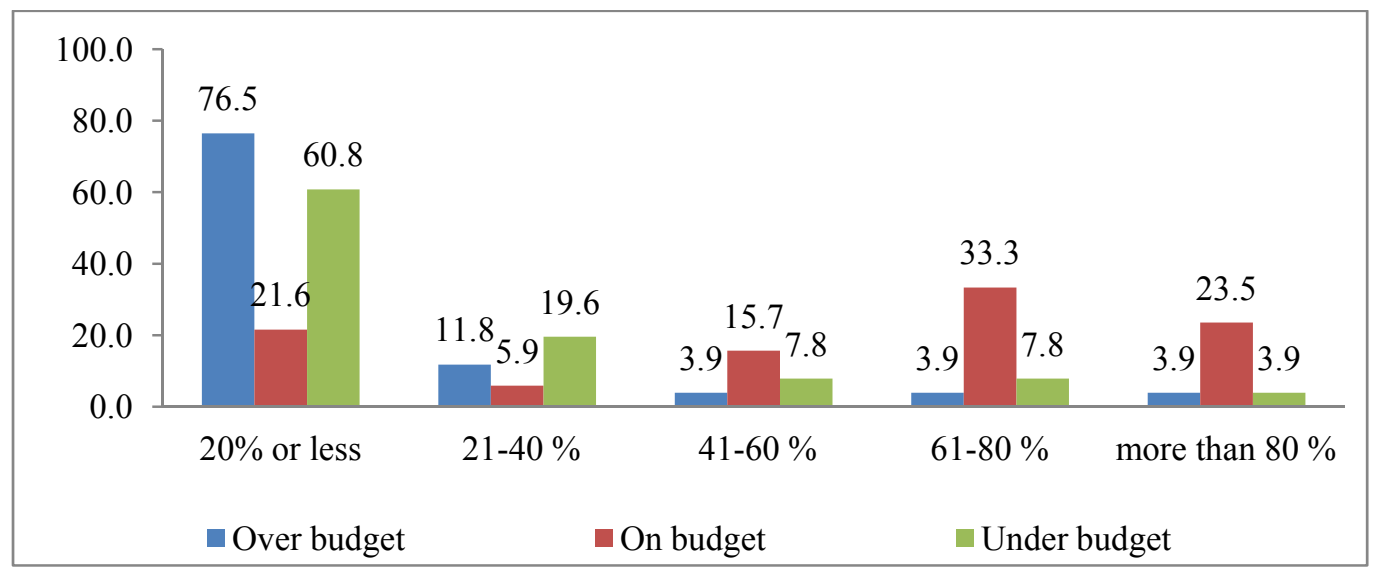

Figure 4.9: Project Performance - Budget

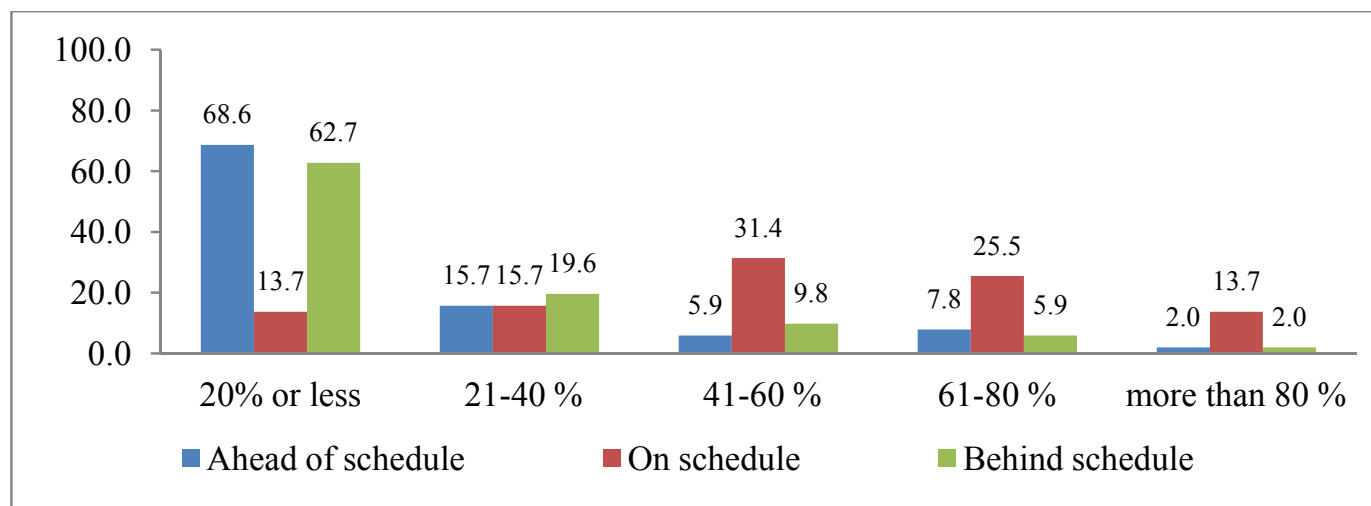

Figure 4.10: Project Performance - Schedule

A very similar trend to the Figure 4.9 can also be observed in Figure 4.10 where again high number of respondents indicated $20 \%$ or less of their projects as either ahead of schedule or behind schedule. And more respondents indicated that higher percentage of their projects performs as planned and meet their project schedule. Figure 4.11 repeats the trend even more strongly with even higher number of projects meeting the project quality expectations and only few deviating from the expected quality in terms of both being below expectation and exceeding expectation. 


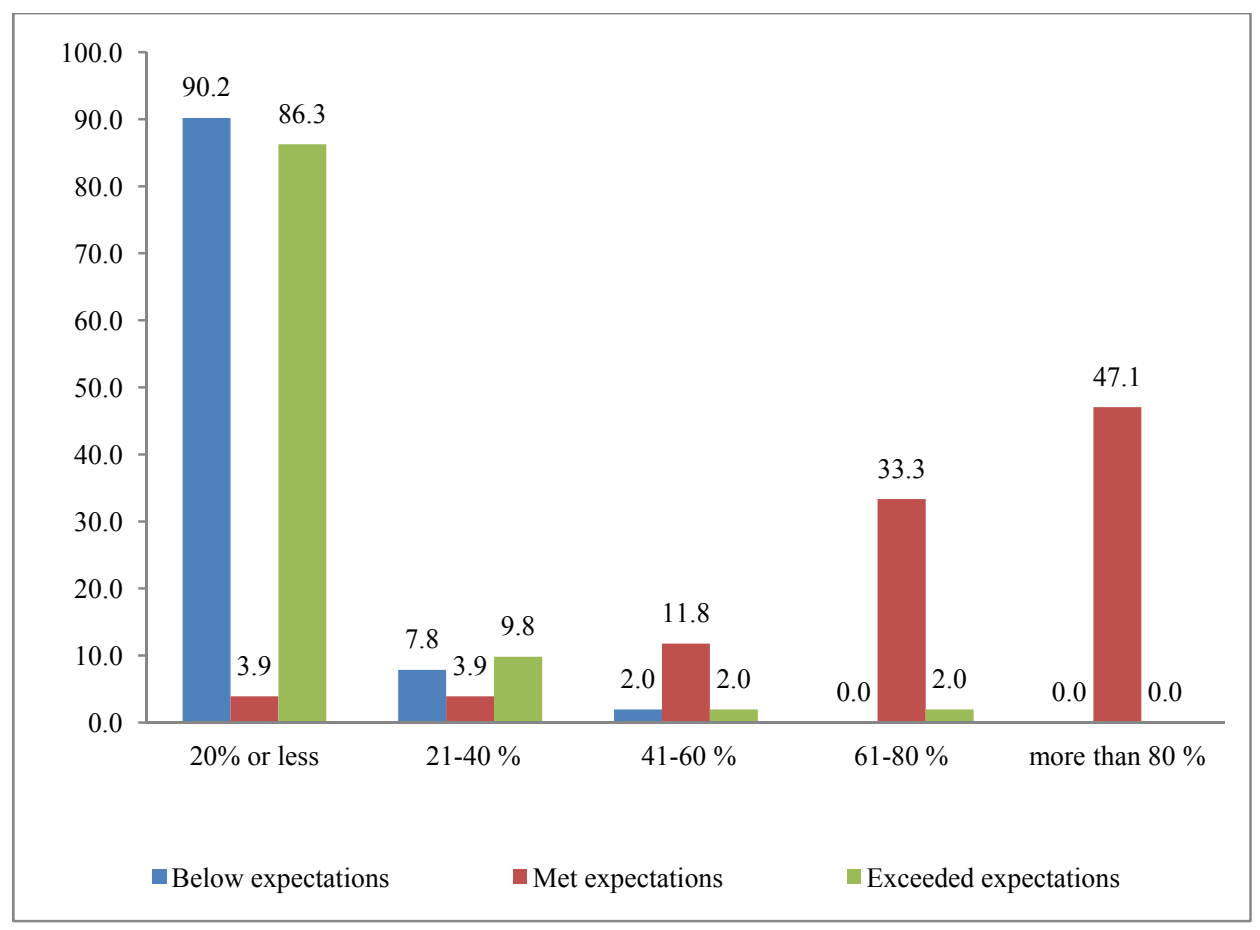

Figure 4.11: Project Performance - Quality

\subsubsection{RELATIONSHIP BETWEEN ICT AND IPD}

While IPD is gaining significant attention lately from educators and researchers alike, the current body of knowledge lacks how project owners, the key stakeholder in construction deciding on the type of project delivery system, perceive IPD. In addition, there has been little or no study investigating the relationship between IPD and ICT, taking degree (extent) of use and type of ICT (internal versus external) in consideration. This section attempts to fill these research gaps. Using 59 survey data collected from various public sector owners in the US, this section investigates two research questions, namely, (1) the perception of IPD characteristics on the project delivery effectiveness, and (2) the perception that ICT fosters IPD. The perception about the impact of ICT use on IPD is further investigated by the degree and type of ICT use. 
Figure 4.12 elaborates the schematic analysis model used.

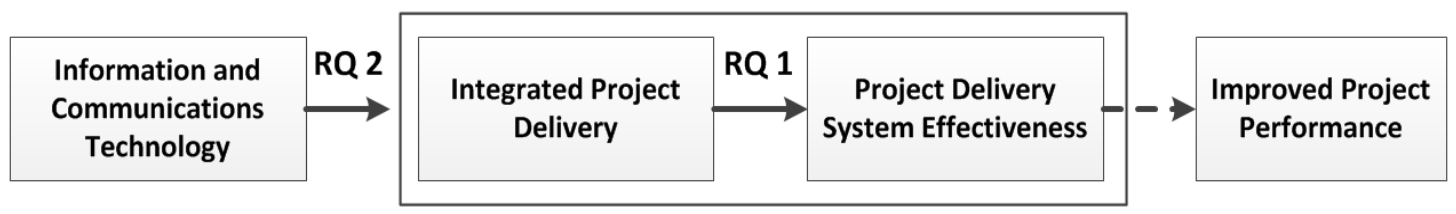

Figure 4.12: Analysis Model

The model is comprised of two research questions. The first one is:

\section{"Does IPD improve effectiveness in project delivery?"}

It addresses how public sector owners perceive IPD. In this study, we assumed that effectiveness in project delivery translates into improved project performance. We recognize that most public sector owners have very little IPD experience and hence, performance of IPD as a delivery system cannot be meaningfully investigated in public sector. Because of this problem, rather than attempting to establish a direct relationship between project performance and IPD, we attempted to measure the perception of public sector owners about IPD's potential to improve project performance.

The second research question

\section{"Does the use of ICT foster IPD?"}

It addresses how public sector owners perceive the impact of ICT use on IPD. Regarding this research question, we also tested how the degree (extent) and type of ICT use (internal or intra-organizational versus external or inter-organizational) influence this perception. To test these aspects of ICT use, we looked into three hypotheses under the 
second research question. The first hypothesis addresses public sector owners' perception on the impact of ICT use on IPD. We assumed a positive association in this hypothesis, as follows:

Hypothesis 1: The use of ICT fosters IPD.

The second hypothesis tests how the degree of ICT use influences the perception that ICT facilitates IPD. As previously mentioned, the difficulty (owing to cost of technology and expertise) of use of ICT has been regarded as a major barrier in adopting IPD (Kent and Becerik-Gerber 2010; Lee et al. 2014). Thus it was hypothesized that those project owners that are using ICT substantially would have a positive perception regarding its impact on IPD. Thus this hypothesis is:

Hypothesis 2: More use of electronic information exchange is positively associated with the perception that the use of ICT fosters IPD.

The third hypothesis investigates how the type of ICT use influences the perception that ICT can facilitate IPD. In addition to the degree of ICT use, type of ICT use (internal or intra-organizational, and external or inter-organizational) is an aspect that may influence this perception. Project participants from different organizations are capable of exchanging information more effectively for better inter-organizational collaboration with greater external use of ICT. Thus, it is very important to have an information model or system that is interoperable with models or systems used by other participants. Therefore, project owners extensively using ICT inter-organizationally should have more positive perception about the relationship between ICT and IPD. 
Hypothesis 3: More external use of electronic information exchange is positively associated with the perception that the use of ICT fosters IPD.

\subsubsection{ICT-IPD RELATIONSHIP DATA ANALYSES}

The research questions discussed previously were tested using the 59 survey data collected from the public sector owners. The questions in 15 to 18 (Appendix A) were used for the tests. Figure 4.13 shows the mapping between the research questions and data sources.

For the first research question, data from question 15 was used. The percentage of "yes" responses for each of the six IPD characteristics was looked into for analysis. Similarly, the first hypothesis under the second question was tested by using the responses to Question 18. The percentages of affirmative responses for each IPD characteristic were analyzed.

For the second hypothesis under the second research question, Questions 16 and 18 were used. For responses to Question 18, three indices, PIFI-(Perception that ICT Fosters IPD) Overall, PIFI-Collaboration, and PIFI-Contract, were developed. The indices count the number of "yes" answers associated with the IPD characteristics. PIFIOverall includes all six characteristics. PIFI-Collaboration counts the number of "yes" responses associated with the three collaboration-related IPD characteristics as shown in Table 4.8. PIFI-Contract, on the other hand, counts the number of affirmative answers associated with the three contract-related IPD characteristics, also shown in Table 4.8. 


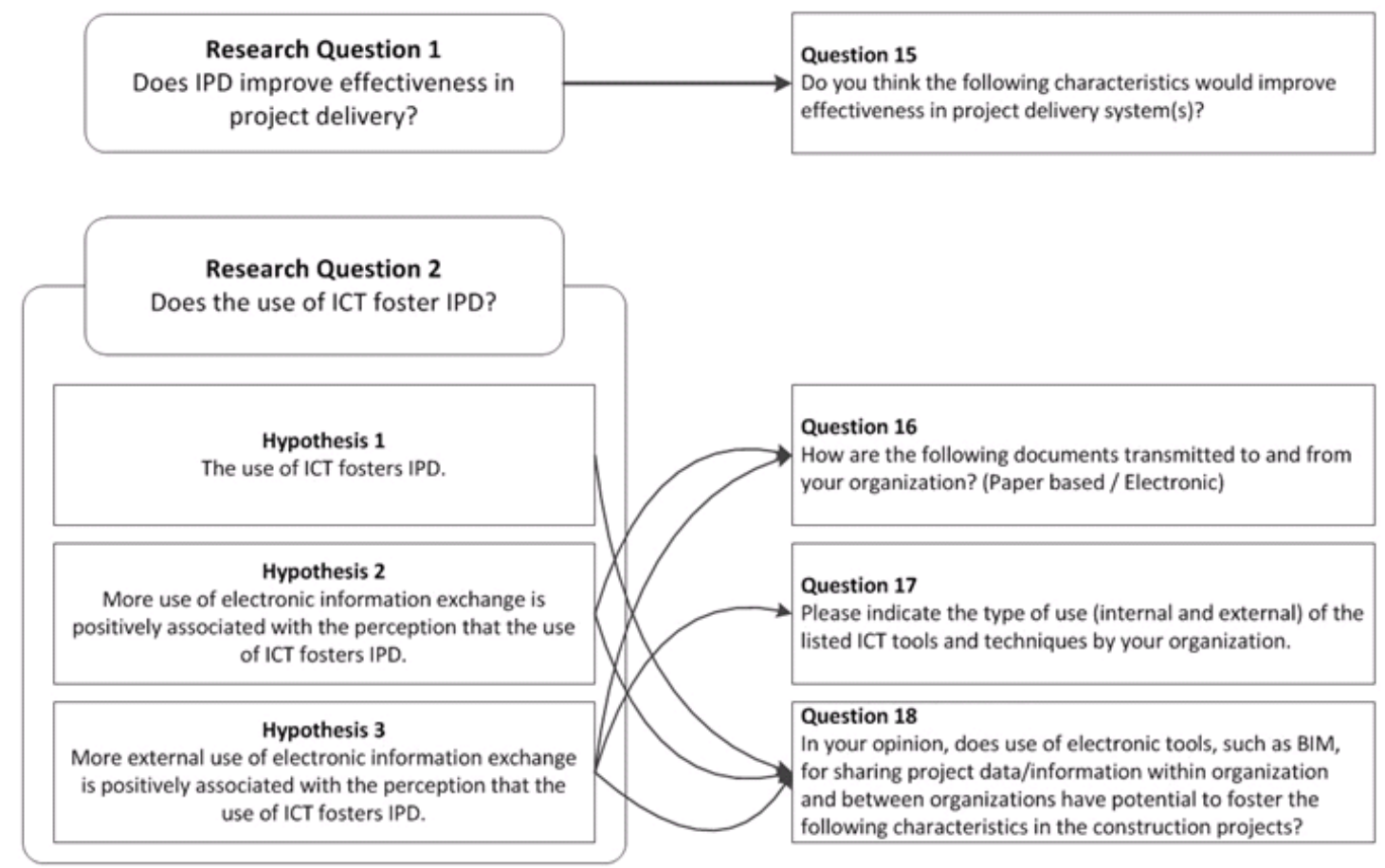

Figure 4.13: Mapping of the Research Questions and Data Sources

Table 4.8: Mapping of Six IPD Characteristics to Two Main IPD Characteristic Categories

\begin{tabular}{|l|c|}
\hline \multicolumn{1}{|c|}{ IPD Characteristic } & Category \\
\hline Early Involvement of Key Participants (EIKP) & \multirow{3}{*}{ Collaboration-related } \\
\cline { 1 - 1 } Jointly Developed and Validated Goal (JDVG) & \\
\hline Collaborative Decision Making and Control (CDMC) & \multirow{2}{*}{ Contract-related } \\
\hline Shared Risk and Reward (SRR) & \\
\hline Multiparty Contract (MC) & \\
\hline Liability Waivers among Key Participants (LWKP) & \\
\hline
\end{tabular}

For all indices, a higher number indicates the respondent has a higher positive perception about the impact of ICT on IPD. Responses to Question 16 were used to develop the ICT score, measuring the degree of ICT use. The scale in the question was converted to a scale of one to five with one indicating total paper based transfer $(100 / 0 \%)$ and five indicating total electronic transfer (0/100\% see Question 16 Appendix A).

Five scale values for the 10 document types shown in the figure were averaged to calculate the ICT score. The ICT score ranges from one, meaning all documents were 
transmitted by paper version, to five, indicating all documents are electronically transmitted. After developing the ICT scores, they were divided into two groups, less use of ICT group and more use of ICT group, by using the median value, 4.5. For both groups, the average values of PIFI indices were calculated. The second hypothesis can be considered valid if more use of ICT is related to a higher PIFI average value than the group indicating less use of ICT. A t-test was conducted to test the statistical significance of the mean values difference.

In the third hypothesis, the type of ICT use was taken into account. As presented earlier, it was conjectured that organizations using ICT tools externally (or interorganizationally) should have a higher favorable perception that 'ICT use can foster IPD'. Question 17 was used to classify the type (internal, external, or both) of ICT use for each response. The Question 17 (Appendix A) asks the type of ICT use for nine ICT tools. (For the analysis, organizations using ICT tools both internally and externally were considered external users.)

Among the nine types of ICT tools in the question, two - emails and fax - were excluded from consideration during analyses. We thought emails and fax, although ICT tool, are too common and are used both internally and externally extensively by almost all organizations, big or small, nowadays.

We considered only responses that have more than four ICT tools selected. If more than three tools are chosen in any category (internal or external), and if it is higher than the other category the respondent is considered a predominant user of that category. In other words, more internal than external, is considered internal, and more external than internal, is considered external. Responses were excluded from analyses if equal number 
of tools is chosen from both categories, as they could not be classified in either category. By using the degree of ICT use (ICT Score) and type of ICT use, the responses were divided into four groups as shown in Figure 4.14. For the four groups, the mean values of the PIFI-Overall scores were calculated and a two-way analysis of variance (ANOVA) test was conducted.

\subsection{RESEARCH QUESTION 1}

Table 4.9 shows the results for the first research question. Note that there were five to six incomplete sets of data in each category. Therefore, sum of all responses in each category is either 54 (for EIKP, SRR, and JDVG) or 53 (for MC, CDMC, and LWKP). The percentages in the table were calculated based on the complete sets of data. As such the sum of percentages for each IPD characteristic is $100 \%$. As shown in the Table 9, collaboration-related IPD characteristics such as EIKP, JDVG, and CDMC show high percentages of affirmative responses, indicating that collaborations between project team members in the early project phase should contribute to effective project delivery system. On the other hand, contract-related IPD characteristics, MC and LWKP, show lower percentages of "yes" responses and higher percentages of "not sure" responses. Interestingly, SRR, a contract-related IPD characteristic, has high percentage of "yes" responses with lower percentage of "not sure" answers. Compared with other two contract-related IPD characteristics, this characteristic is not new and has been implemented in various contract methods such as guaranteed maximum price (GMP). 


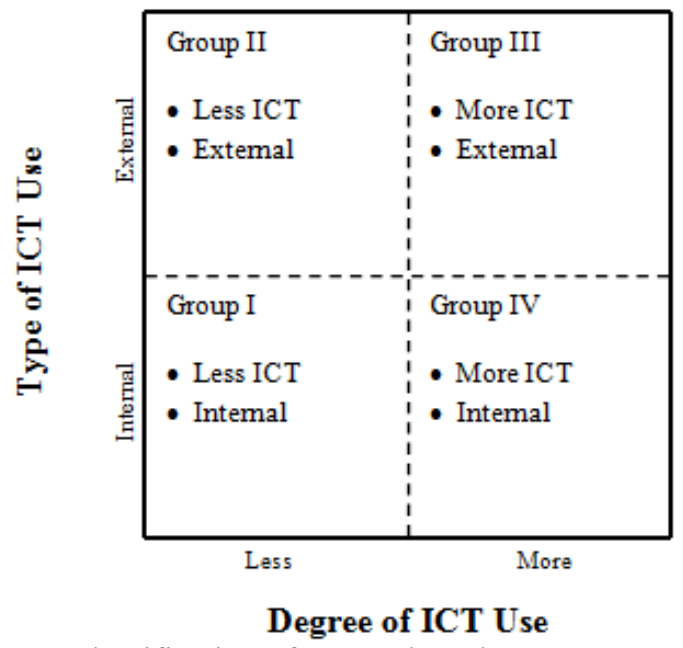

Figure 4.14: Classification of groups based on Degree and Type of ICT use

Having more experiences about this characteristic may have caused the high percentage of affirmative responses and lower percentage of "not sure" answers than MC or LWKP.

Overall, public sector owners perceived that four IPD characteristics, EIKP, SRR, CDMC, and JDVG, would improve effectiveness of project delivery system. The contract-related IPD characteristics except SRR showed lower percentages of "yes" response. As MC is a core characteristic of so-called 'pure' IPD projects, the perception about this characteristic should be improved for successful implementation of IPD across the public sector construction industry.

\subsection{RESEARCH QUESTION 2}

The second research question consists of three hypotheses as shown in Figure 4.13. The first hypothesis, the use of ICT fosters IPD, was tested by using the data for the Question 18 (Appendix A). The responses for the question are summarized in Table 4.10. 
Table 4.9: Responses for the Potential of IPD Characteristics' Contribution to the Project Delivery System Effectiveness

\begin{tabular}{|l|c|c|c|}
\hline \multicolumn{1}{|c|}{ IPD Characteristics } & Response & N & Percentage \\
\hline Early Involvement of Key Participants (EIKP) & Yes & 51 & $94.4 \%$ \\
\cline { 2 - 4 } & No & 1 & $1.9 \%$ \\
\cline { 2 - 4 } & Not Sure & 2 & $3.7 \%$ \\
\hline \multirow{4}{*}{ Shared Risk and Reward (SRR) } & Yes & 41 & $75.9 \%$ \\
\cline { 2 - 4 } & No & 2 & $3.7 \%$ \\
\cline { 2 - 4 } & Not Sure & 11 & $20.4 \%$ \\
\hline \multirow{4}{*}{ Multiparty Contract (MC) } & Yes & 20 & $37.7 \%$ \\
\cline { 2 - 4 } & No & 12 & $22.6 \%$ \\
\cline { 2 - 4 } & Not Sure & 21 & $39.6 \%$ \\
\hline \multirow{2}{*}{$\begin{array}{l}\text { Collaborative Decision Making and Control } \\
\text { (CDMC) }\end{array}$} & Yes & 38 & $71.7 \%$ \\
\cline { 2 - 4 } & No & 5 & $9.4 \%$ \\
\cline { 2 - 4 } & Not Sure & 10 & $18.9 \%$ \\
\hline \multirow{2}{*}{$\begin{array}{l}\text { Liability Waivers among Key Participants } \\
\text { LWK) }\end{array}$} & Yes & 15 & $28.3 \%$ \\
\cline { 2 - 4 } & No & 14 & $26.4 \%$ \\
\cline { 2 - 4 } & Not Sure & 24 & $45.3 \%$ \\
\hline Jointly Developed and Validated Goal (JDVG) & Yes & 37 & $68.5 \%$ \\
\cline { 2 - 4 } & No & 5 & $9.3 \%$ \\
\cline { 2 - 4 } & Not Sure & 12 & $22.2 \%$ \\
\hline
\end{tabular}

Similar to the responses for Question 15, there were five or six missing data for each category and the percentages in Table 4.10 were calculated only based on the valid responses. The trend shown in Table 10 is somewhat similar to that in Table 4.9. Collaboration-related IPD characteristics, EIKP, CDMC, and JDVG, show higher percentages of "yes" responses than contract-related IPD characteristics. This finding is intuitive as one of the benefits of ICT use is enhanced collaboration as highlighted by Anumba et al. 2000, and Dossick and Sakagami 2008. For the contract-related IPD characteristics, as shown in Table 4.10, public sector owners tend to be less positive about the fosterage of ICT use. Compared with the collaboration-related IPD characteristics, the impact of ICT use on the contract-related IPD characteristics appears to be weak. Some suggested that ICT's document management function contributes to effective contract management (Back and Moreau 2001) but the perception that paper- 
based documents imply 'binding' and that electronic documents do not, has restricted this opportunity (O'Brien 2000). In fact, regarding the ICT use and contractual issues, it has been asserted that clear description of ICT use as a collaboration tool in the contract is a key factor for successful implementation of ICT (Dossick and Sakagami 2008; Erdogan et al. 2008; Gilligan and Kunz 2007). It was noted from the information in Table 10 that more than $50 \%$ of the respondents are not sure about the potential that ICT use fosters MC and liability waivers among key participants (LWKP), whereas SRR another contract-related characteristic, has received higher percentage of affirmative responses.

Table 4.10: Responses for the Potential that ICT Use Fosters the IPD Characteristics

\begin{tabular}{|l|c|c|c|}
\hline \multicolumn{1}{|c|}{ IPD Characteristics } & Response & $\mathbf{N}$ & Percentage \\
\hline Early Involvement of Key Participants (EIKP) & Yes & 31 & $57.4 \%$ \\
\cline { 2 - 4 } & No & 6 & $11.1 \%$ \\
\cline { 2 - 4 } & Not Sure & 17 & $31.5 \%$ \\
\hline \multirow{4}{*}{ Shared Risk and Reward (SRR) } & Yes & 20 & $37.0 \%$ \\
\cline { 2 - 4 } & No & 10 & $18.5 \%$ \\
\cline { 2 - 4 } & Not Sure & 24 & $44.4 \%$ \\
\hline \multirow{4}{*}{ Multiparty Contract (MC) } & Yes & 13 & $24.1 \%$ \\
\cline { 2 - 4 } & No & 11 & $20.4 \%$ \\
\cline { 2 - 4 } & Not Sure & 30 & $55.6 \%$ \\
\hline \multirow{2}{*}{$\begin{array}{l}\text { Collaborative Decision Making and Control } \\
\text { (CDMC) }\end{array}$} & Yes & 32 & $59.3 \%$ \\
\cline { 2 - 4 } & No & 4 & $7.4 \%$ \\
\cline { 2 - 4 } & Not Sure & 18 & $33.3 \%$ \\
\hline \multirow{2}{*}{$\begin{array}{l}\text { Liability Waivers among Key Participants } \\
\text { (LWKP) }\end{array}$} & Yes & 16 & $29.6 \%$ \\
\cline { 2 - 4 } & No & 10 & $18.5 \%$ \\
\cline { 2 - 4 } & Not Sure & 28 & $51.9 \%$ \\
\hline Jointly Developed and Validated Goal (JDVG) & Yes & 25 & $47.2 \%$ \\
\cline { 2 - 4 } & No & 8 & $15.1 \%$ \\
\cline { 2 - 4 } & Not Sure & 20 & $37.7 \%$ \\
\hline
\end{tabular}

This is consistent with the finding in Table 4.9. Therefore, it is reasonable to conclude that the responses about MC and LWKP in Table 4.10 are also related with the fact that those two characteristics are fairly new and not widely known to public owners. 
The second hypothesis was tested by using two questions, i.e. Questions 16 and 18 (Appendix A). The ICT score, measuring the degree of ICT use, was developed by using the answers of Question 16 (Appendix A). In addition to testing the second hypothesis, this ICT score is also helpful in assessing how public sector owners are using ICT tools. Table 4.11 summarizes the descriptive statistics for the ICT score and how different types of documents are transmitted.

As shown in the Table 4.11, mean of the ICT score is 4.42, indicating that documents are transmitted more by electronic means than by paper-based options. Among various types of documents, schedules are transmitted more by electronic means compared to other document types. On the other hand, the type of document that is least electronically transmitted is contracts. This finding is consistent with O'Brien (2000), mentioned earlier.

Table 4.12 shows the descriptive statistics of the three PIFI indices for the two groups, a group using ICT more and a group using ICT less. The group using ICT more has higher mean values than the group using ICT less. This indicates that organizations using ICT more tend to have more positive perception about the impact of ICT on the IPD characteristics.

A series of $t$-tests were conducted to test the statistical significance of the mean differences and the results are summarized in Table 4.13. 
Table 4. 11: Descriptive Statistics: ICT Score and Documents' Transfer Type

\begin{tabular}{|l|c|c|c|}
\hline ICT Score / Document Type & N & Mean & Std. Dev. \\
\hline ICT Score & 56 & 3.42 & 0.83 \\
\hline Plans / Shop Drawings & 56 & 3.36 & 0.92 \\
\hline Design and Specifications & 56 & 3.46 & 0.87 \\
\hline Schedules (e.g., Primavera files) & 56 & 3.88 & 0.94 \\
\hline $\begin{array}{l}\text { Estimates / Bill of Quantities } \\
\text { (spreadsheets / estimating programs) }\end{array}$ & 55 & 3.69 & 1.09 \\
\hline Purchase Orders & 56 & 3.43 & 1.28 \\
\hline Bid Documents & 54 & 3.43 & 1.30 \\
\hline Contracts & 56 & 2.73 & 1.43 \\
\hline Transmittals, e.g., RFIs & 56 & 3.70 & 1.11 \\
\hline Change Orders, etc. & 56 & 3.02 & 1.37 \\
\hline Payments - Fund Transfers & 56 & 3.50 & 1.49 \\
\hline
\end{tabular}

Table 4. 12: Descriptive Statistics: PIFI Indices by the Degree of ICT Use

\begin{tabular}{|c|c|c|c|c|c|}
\hline PIFI Index & ICT Use & $\mathbf{N}$ & Mean & Std. Deviation & Std. Error Mean \\
\hline \multirow{2}{*}{ Overall } & More Use & 28 & 2.96 & 2.43 & 0.459 \\
\cline { 2 - 6 } & Less Use & 26 & 2.08 & 2.24 & 0.440 \\
\hline \multirow{2}{*}{ Collaboration } & More Use & 28 & 1.82 & 1.34 & 0.252 \\
\cline { 2 - 6 } & Less Use & 26 & 1.42 & 1.39 & 0.273 \\
\hline \multirow{2}{*}{ Contract } & More Use & 28 & 1.14 & 1.38 & 0.261 \\
\cline { 2 - 6 } & Less Use & 26 & 0.65 & 1.06 & 0.207 \\
\hline
\end{tabular}

It should be noted that one-tailed tests, instead of two-tailed tests, were conducted as we hypothesized that more use of ICT is associated with higher positive perception. As shown in the table, the significance level for PIFI-Overall index is 0.085 (equal variance can be assumed because of the high significance of Levene's test), which is marginal at the level of $\alpha=0.05$. Based on the significance level and mean values in Table 12, we conclude that the second hypothesis in this study is supported. In other words, it can be 
concluded that organizations using ICT more tend to have a positive perception that ICT use fosters IPD. The mean difference between the two groups was found to be marginally statistically significant at the level of $\alpha=0.05$. A comparison between PIFICollaboration and PIFI-Contract indicates that the "more ICT use group" has higher PIFI index mean values than the group with less use of ICT. Interestingly, the significance level for PIFI-Contract is 0.074 (equal variance cannot be assumed, as the significance of Levene's test was low). Thus it can be assumed that the contract-related IPD characteristics contribute to the low significance level for PIFI-Overall. This indicates that more use of ICT contributes to having a positive perception on the impact of ICT as far as the contract-related IPD characteristics are concerned.

Table 4.13: T-test Results for the Second Hypothesis

\begin{tabular}{|c|c|c|c|c|c|c|c|c|}
\hline \multirow{3}{*}{ PIFI Index } & \multirow{2}{*}{$\begin{array}{c}\text { Equal } \\
\text { Variance }\end{array}$} & Fevene's Test & \multicolumn{5}{|c|}{ t-test for Equality of Means } \\
\cline { 3 - 9 } & & Sig. & $t$ & df & $\begin{array}{c}\text { Sig. } \\
\text { (1-tailed) }\end{array}$ & $\begin{array}{c}\text { Mean } \\
\text { Diff. }\end{array}$ & $\begin{array}{c}\text { Std. Error } \\
\text { Diff. }\end{array}$ \\
\hline Overall & Assumed & 0.321 & 0.573 & -1.392 & 52 & 0.085 & -0.887 & 0.637 \\
& Not Assumed & & & -1.396 & 52.000 & 0.084 & -0.887 & 0.636 \\
\hline Collaboration & Assumed & 0.463 & 0.499 & -1.074 & 52 & 0.144 & -0.398 & 0.371 \\
& Not Assumed & & & -1.072 & 51.305 & 0.144 & -0.398 & 0.372 \\
\hline Contract & Assumed & 6.927 & 0.011 & -1.454 & 52 & 0.076 & -0.489 & 0.336 \\
& Not Assumed & & & -1.468 & 50.221 & 0.074 & -0.489 & 0.333 \\
\hline
\end{tabular}

The third hypothesis was investigated by a two-way ANOVA test. The descriptive statistics for the four groups categorized by the degree and type of ICT use and the results of the two-way ANOVA test are summarized in Tables 4.14 and 4.15, respectively. 
Table 4.14: Descriptive Statistics: PIFI Overall Index by Degree and Type of ICT Use

\begin{tabular}{|c|c|c|c|c|}
\hline $\begin{array}{c}\text { Degree of ICT } \\
\text { Use }\end{array}$ & Type of ICT Use & Mean & Std. Deviation & N \\
\hline \multirow{3}{*}{ More Use } & Internal & 4.10 & 2.08 & 10 \\
\cline { 2 - 5 } & External & 2.38 & 2.50 & 13 \\
\cline { 2 - 5 } & Total & 3.13 & 2.44 & 23 \\
\hline \multirow{3}{*}{ Less Use } & Internal & 1.20 & 2.68 & 5 \\
\cline { 2 - 5 } & External & 2.35 & 2.18 & 17 \\
\cline { 2 - 5 } & Total & 2.09 & 2.29 & 22 \\
\hline \multirow{3}{*}{ Total } & Internal & 3.13 & 2.62 & 15 \\
\cline { 2 - 5 } & External & 2.37 & 2.28 & 30 \\
\cline { 2 - 5 } & Total & 2.62 & 2.40 & 45 \\
\hline
\end{tabular}

Table 4.15: Two-Way ANOVA Result

\begin{tabular}{|c|c|c|c|c|c|c|c|}
\hline Source & $\begin{array}{l}\text { Type III } \\
\text { Sum of } \\
\text { Squares }\end{array}$ & $\begin{array}{l}\text { Degree of } \\
\text { Freedom }\end{array}$ & $\begin{array}{l}\text { Mean } \\
\text { Square }\end{array}$ & $\mathbf{F}$ & Significance & $\eta_{p}^{2}$ & $\begin{array}{c}\text { Observed } \\
\text { Power }^{\mathrm{a}}\end{array}$ \\
\hline $\begin{array}{c}\text { Corrected } \\
\text { Model }\end{array}$ & 33.919 & 3 & 11306 & 2.120 & 0.112 & 0.134 & 0.502 \\
\hline $\begin{array}{l}\text { Degree of } \\
\text { ICT Use }\end{array}$ & 19.724 & 1 & 19.724 & 3.698 & 0.061 & 0.083 & 0.467 \\
\hline $\begin{array}{c}\text { Type of ICT } \\
\text { Use }\end{array}$ & 0.726 & 1 & 0.726 & 0.136 & 0.714 & 0.003 & 0.065 \\
\hline Interaction & 18.881 & 1 & 18.881 & 3.540 & 0.067 & 0.079 & 0.451 \\
\hline
\end{tabular}

a. Computed using $a=0.05$

For this analysis, responses that missed one of the three type of data (PIFI, degree, and type of ICT use) are excluded. As a result, a sample size of 45 was used in this test. As shown in Table 15, the main effect of the type of ICT use (internal v. external) on the PIFI-Overall index was not statistically significant: $F(1,41)=0.136, p=0.714, \eta_{p}{ }^{2}=$ 0.003. Also, Table 4.14 shows that the "internal ICT use group" has higher positive perception regarding the impact of ICT on IPD $(\mathrm{M}=3.13, \mathrm{SD}=2.62)$ than the external ICT use group $(\mathrm{M}=2.37, \mathrm{SD}=2.28)$. Based on these results, we rejected the third hypothesis in this study. 
The main effect of degree of ICT use (more use v. less use) on the PIFI-Overall index was found to be statistically significant marginally: $F(1,41)=3.698, p=0.061, \eta_{p}^{2}$ $=0.083$. This result, together with the mean values in Table 4.14 (3.13 for the more ICT use group and 2.09 for the less ICT use group), is consistent with the finding shown in Table 4.12. More importantly, a significant interaction effect was found between type of ICT use and degree of ICT use: $F(1,41)=3.540, p=0.067, \eta_{p}{ }^{2}=0.079$. That is, the group using ICT more and internally has substantially more positive perception about the impact of ICT on IPD $(\mathrm{M}=4.10, \mathrm{SD}=2.08)$ than the group using ICT less and internally $(\mathrm{M}=1.20, \mathrm{SD}=2.68)$. On the other hand, for the groups using ICT externally, the difference in the perception between more use group $(\mathrm{M}=2.38, \mathrm{SD}=2.50)$ and less use group $(\mathrm{M}=2.35, \mathrm{SD}=2.18)$ was minimal. The interaction effect is also illustrated in Figure 4.15.

As shown in the figure, the difference in the mean values for internal ICT use groups (between more use and less use) was substantial, whereas the same value for external ICT use groups was minimal. This interesting finding, we think is related with lack of interoperability as well as contractual clauses that do not allow project participants to share project information externally in interoperable forms, typical in public projects. Although inter-organizational collaboration among project participants is crucial, external information integration to achieve an effective level of collaboration in the construction industry is very challenging (Taylor and Bernstein 2009). Thus, it can be conjectured that project owners using ICT externally have achieved only limited amount of benefits, leading to this perception that ICT's impact on IPD is minimal. On the other hand, intra-organizational information integration (as opposed to inter- 
organizational) is relatively easy to achieve. Thus, the project owners have a positive perception of ICT impact on IPD with more experience with ICT.

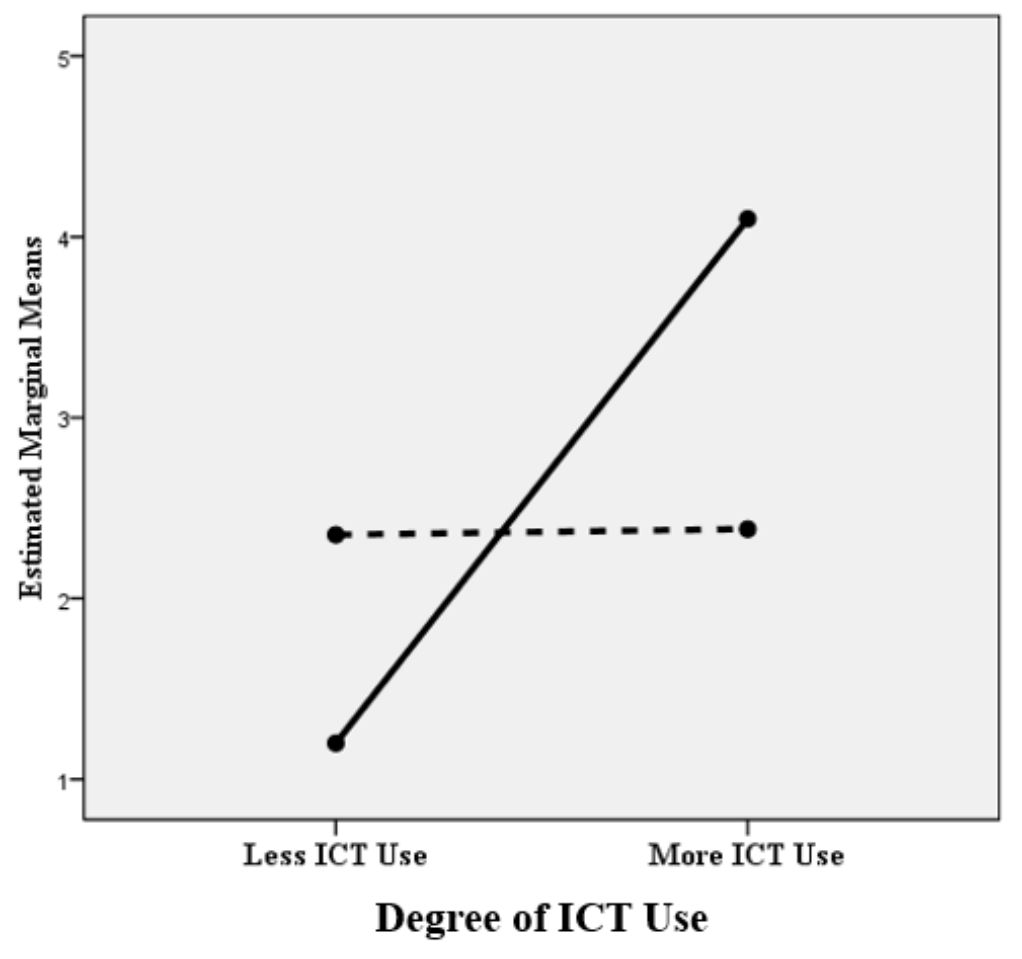

\section{Type of ICT Use — Internal ----- External}

Figure 4.15: Interaction effect of type of ICT use and degree of ICT use for the perception about the impact of ICT on IPD

\subsubsection{DISCUSSION ON ANALYSES OF OUTCOMES}

By using 59 survey data from the public sector owners, two research questions were tested in this section. From the first research question, the survey data revealed that the public sector owners perceived that four IPD characteristics, EIKP, SRR, CDMC, and JDVG, would improve effectiveness of project delivery system. From the second research question, three hypotheses were tested with different statistical analyses. By testing the first hypothesis, we found that the public sector owners perceived that the use 
of ICT fosters collaboration-related IPD characteristics - namely, EIKP, CDMC, and JDVG. An interesting finding consistently observed from the two research questions, shown in Tables 9 and 10, was high percentages of "not sure" responses for the two contract-related IPD characteristics, MC and liability waivers among key participants (LWKP). This indicates that these two characteristics may still be new to public sector owners. Since MC is a core IPD characteristic, it is necessary to disseminate this characteristic for diffusing the new project delivery system.

The second research question was further investigated by taking degree of ICT use and type of ICT use into account. When comparing more ICT use and less ICT use groups, data analyses revealed that the group with more ICT use tends to have more positive perception about the impact of ICT use on IPD. We also found that the difference in perception between the two groups is statistically significant, although marginally. Thus the second hypothesis is supported in this study. In addition, it was found that the perception difference is statistically meaningful marginally for the contract-related IPD characteristics but not for the collaboration-related characteristics. This is very interesting because the relationship between ICT use and contract-related IPD characteristics is not clear. Further investigation about this relationship should be conducted in the future studies.

The third hypothesis was investigated by a two-way ANOVA test. It was found that type of ICT use did not make a statistically significant difference on the perception regarding the impact of ICT use on IPD. Therefore, the third hypothesis was rejected. However, interestingly, it was also found that the group using ICT more and internally has substantially higher positive perception than the group using ICT less and internally. 
But, when comparing two groups using ICT externally, the difference was found to be minimal. Interoperability, or lack thereof, is probably the reason for this but further study must be conducted to be certain.

\subsection{CHAPTER SUMMARY}

This chapter first provided the organizational profile of the public owner organizations who participated in the survey. It further established and reported the stateof-the-practice of public owner organization regarding the use of IPD and ICT through descriptive analysis. Furthermore, and most importantly this chapter also investigated the relationship between IPD and ICT from the perspective of public sector owners through rigorous inferential analysis. In general, it can be concluded that IPD characteristics improve project delivery effectiveness. In addition, the public owner organizations perceive that ICT fosters IPD. However, the perception is influenced by the degree of their ICT use. More use of ICT contributes to more positive perception about the impact of ICT on IPD but it was found to be valid only for the internal or intra-organizational use of ICT. The next chapter will present Integrated Project Delivery Readiness Assessment Model (IPD-RAM) developed. 


\section{CHAPTER-5: INTEGRATED PROJECT DELIVERY READINESS ASSESSMENT}

\section{MODEL (IPD-RAM)}

\subsection{INTRODUCTION}

In this chapter, the development of the model for measuring IPD readiness in an organization is discussed. Table 5.1 describes how the major findings from the survey helped in developing the IPD-readiness assessment model (IPD-RAM). Through the survey analysis it was found that there were two distinct categories of characteristics, collaboration related and contract related. This classification was reflected in IPD-RAM and the IPD principles were categorized under these two classifications. Another major finding from the survey was that IPD principles improve the project delivery effectiveness indicating the importance of finding where a project stands with respect to IPD principles. As such in the proposed model, subjective score scales have been developed to indicate IPD readiness.

Table 5.1 Links between Survey Findings and Model Components

\begin{tabular}{|l|l|}
\hline Survey Findings & IPD Readiness Assessment Model \\
\hline $\begin{array}{l}\text { IPD characteristics can be divided into } \\
\text { collaboration related and contract related } \\
\text { characteristics. }\end{array}$ & $\begin{array}{l}\text { Classification of IPD principles into Contractual } \\
\text { and collaboration related principles. }\end{array}$ \\
\hline $\begin{array}{l}\text { Impact of IPD characteristics on project } \\
\text { delivery effectiveness can be incremental. }\end{array}$ & Measuring scales for IPD principle readiness \\
\hline $\begin{array}{l}\text { More ICT use tends to have more positive } \\
\text { perception about the impact of ICT use on } \\
\text { IPD. }\end{array}$ & Levels of ICT use \\
\hline $\begin{array}{l}\text { ICT fosters collaboration-related IPD } \\
\text { characteristics, primarily. }\end{array}$ & $\begin{array}{l}\text { ICT Push, IPD Pull concept to differentiate } \\
\text { between IPD principles }\end{array}$ \\
\hline
\end{tabular}

Various aspects of the model are discussed in this chapter. The application of the model based on a hypothetical case $\alpha$ is demonstrated, as well. 


\subsection{INPUTS FROM FOCUS GROUP}

The focus group, mentioned earlier, for this research consisted of the following executives of the Facilities Management Department (FMD) - FIU who were selected based on their areas of expertise.

1. Associate Vice President, Facilities Management

2. Director, Facilities Construction

3. Director Facilities Planning

4. Associate Director, Insurance

5. Internal Auditor

6. Senior Associate Controller \& Director, Purchasing Services

The focus group was utilized at several stages during the model development, the initial meeting with the focus group helped in identifying the knowledge gap in the owner organization about IPD and the role $\mathrm{n}$ of ICT in realizing benefits from IPD. It was found that the IPD and ICT relation was unclear. As one of the members, raised the question saying "if BIM can be used without IPD, why we need IPD?" This indicates that there was a lack of understanding in the organization related to IPD and BIM. Concerns related to IPD contracts, insurances, and limitation of public owners especially state agencies were raised. Working of shared risk and reward mechanisms and motivations for subcontractors were also areas of concern to the focus group. These inputs especially related to IPD contracts and shared risks and rewards were consistent with the survey findings that also identified the lack of experience and apprehension of the public owners regarding IPD. 


\subsection{IPD-RAM OVERVIEW}

IPD RAM has six major components as represented in Figure 5.1. The first component is associated with the input of project information. The suceeding component related with the process of measuring the IPD readiness of each IPD principle. Readiness measurement scales has been developed for this purpose. Section 5.4 discusses in detail the IPD principles and their scoring mechanism. The third component is also an assessment process i.e. determination of ICT Level for each of the project functions. Section 5.6 describes the project functions and associated levels of ICT. The next three components of the model are results and analysis components. Where first, IPD readiness score presents the snapshot of the project based on the processing of project information through the two measuring components. IPD readiness scores of several projects from same organization are compared to identify IPD readiness gaps. Next output is the sets of recommendations that are suggested based on the identified gaps.

Along with the components discussed above that defined above there are two basic concepts that are critical aspects of the model. The first concept is the ICT push effect and IPD pull effect. The ICT push/IPD pull concept is explained in Figure 5.2. In brief, the idea is that there are certain ICT tools and methods that can directly facilitate or enhance certain IPD principles. This effect can be described by considering ICT tools/methods used for carrying out the project functions which in turn are influencing IPD principles. This is termed as the 'push effect'. It was observed that IPDs that can be pushed by ICT fall in collaborative and behavioral categories. For example. intensified design (ID), a collaborative principle can be facilitated by the use of BIM for developing and sharing the design between project participants by facilitating the interactions 
between the teams. Similarly, open communication (OC), a behavioral principle, can be enhanced by utilizing video conferencing to create virtual organization.

On the other hand, there are certain IPD principles that can be very effective with specific ICT applications. Actually, some IPD principles are ineffective without specific ICT tools or methods. This is termed as a 'pull effect.' For example, liability waivers among key participants (LWKP), a contractual principle, if implemented reduces the fear of claims and litigations. This creates opportunities for team members to collaborate freely, share ideas with each other, and utilize ICTs more. Arguably, all IPD principles can have 'pull' effects, and those can also have some 'push effects.' However, in this research, IPD principles were classified based on predominance of these effects. All contractual IPD principles are classified as having 'pull effect. One behavioral (MRT) and one collaborative principle (EIKP) were also considered to have predominantly 'pull effect'. This concept is discussed in detail in section 5.5.

The second basic concept is the link between IPD principles and ICT levels. This connection is established through project functions. In order to identify project functions, major project phases were considered and critical project functions were identified for each phase. Then the ICT levels at which each of these functions can be carried out were considered. Each function was also considered to have contributions towards IPD principles. Therefore, it can be said that project functions are acting as links between IPD principles and ICT levels. Figure 5.3 demonstrates this concept. 


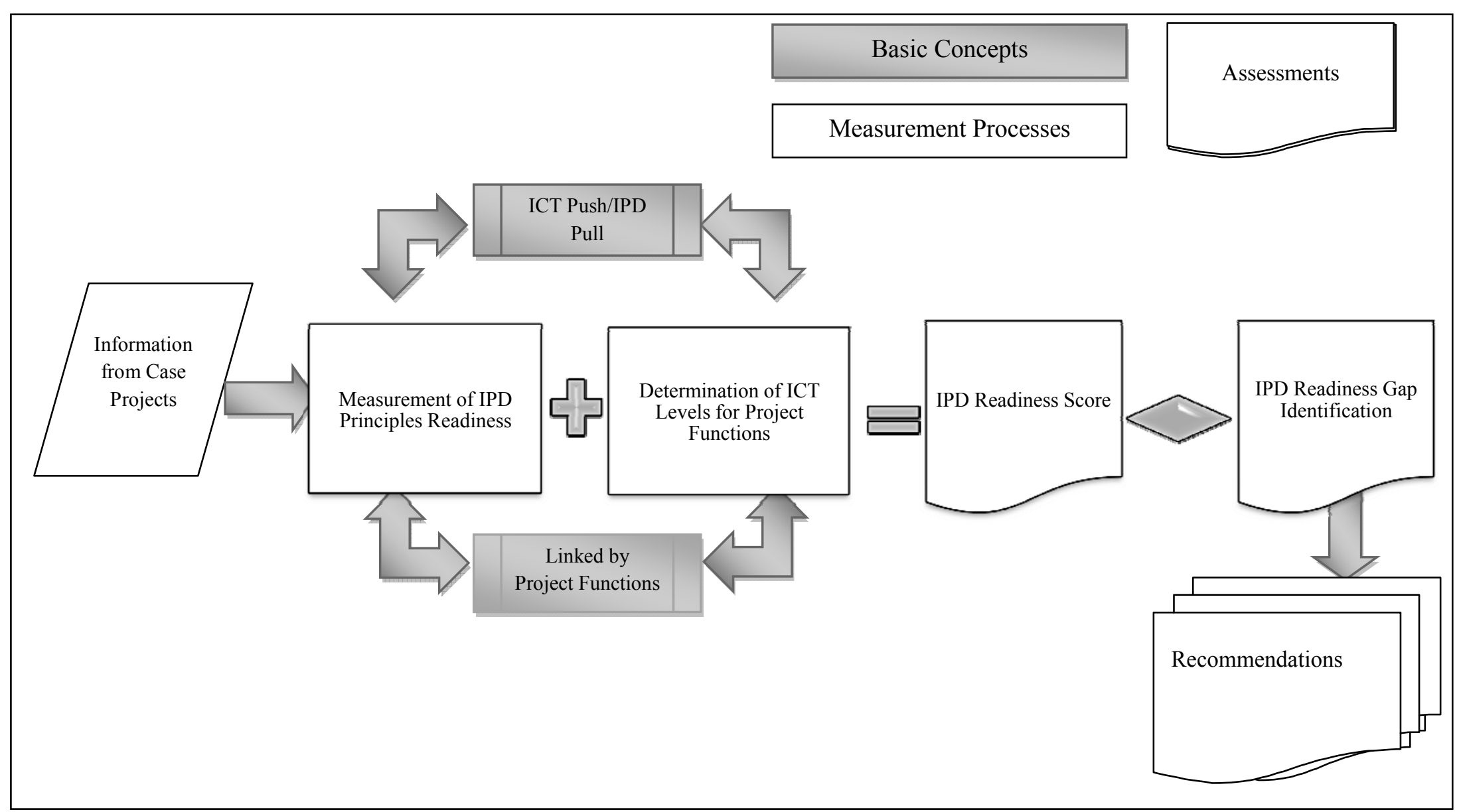

Figure 5.1 Schematic Representation of IPD-RAM 
Figure 5.2 ICT Push/IPD Pull Concepts

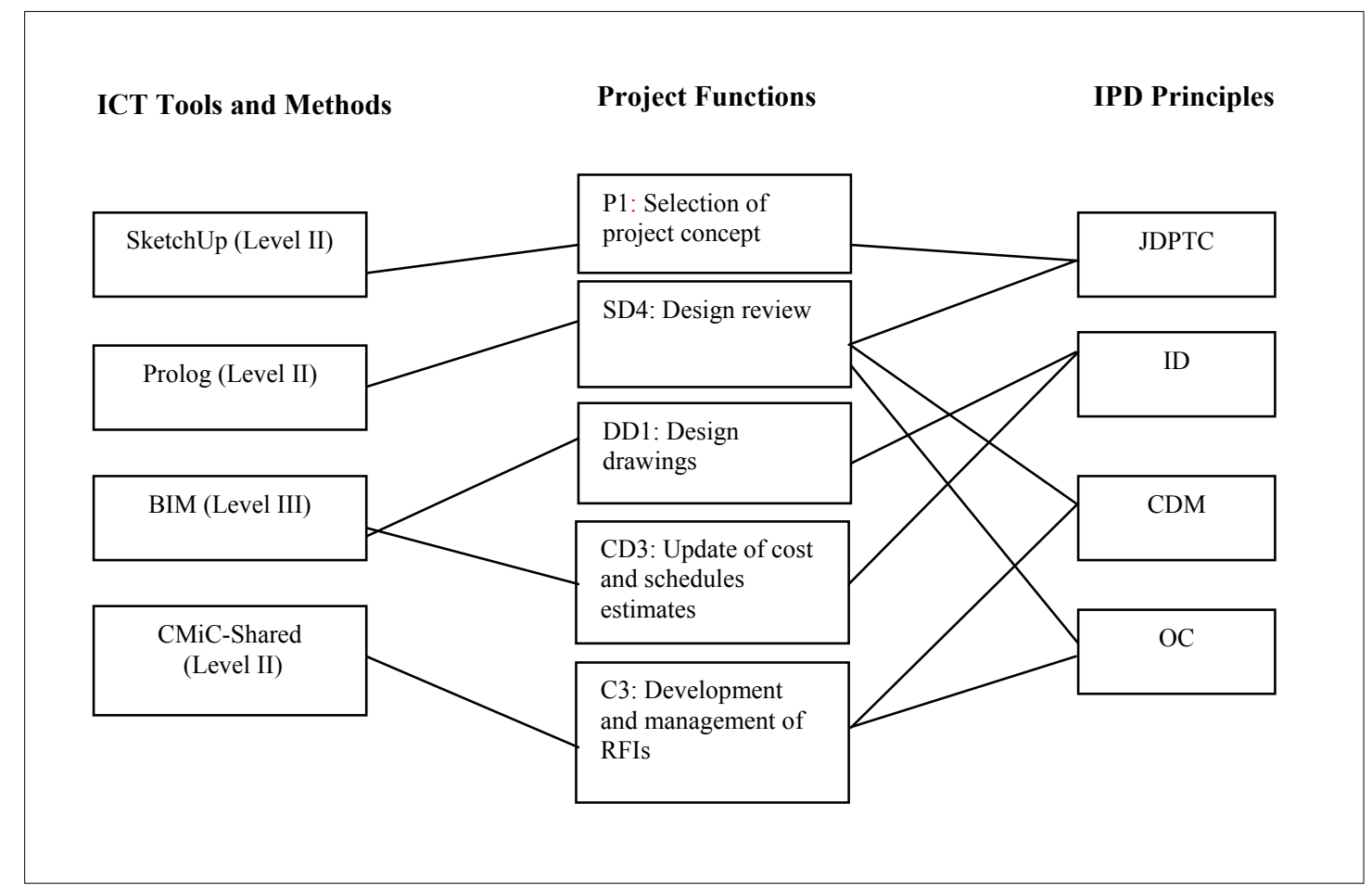

Figure 5.3: Example of Mapping of IPD Principles and ICT Levels through Project Functions 


\subsection{IPD PRINCIPLES AND THEIR SCORING MECHANISM}

Before describing the development of IPD readiness scoring scales, it is important to discuss the basis of selection of IPD Principles. As discussed in earlier, six IPD characteristics were included in the survey. IPD definition has evolved over the recent years and is extended to include more dimensions of project delivery. The term 'characteristic' in the previous definition is replaced with 'principles'. The principles are classified as contractual and behavioral (see section 2.2). Table 5.2 below shows the evolution that has taken place in the development of IPD principles. All IPD principles are included in IPD-RAM, except, 'Key Participants Bound Together as Equal' is not included. Because it can only be realized by a contract that recognizes all key participants as equals. Being a contract it cannot be scaled. Also current most public agencies do not have the authority to make such agreements, therefore this principle was not considered.

To identify the principles on which ICT can affect, the classification of IPD principles in this study is slightly modified from the recent AIA definition. Based on the survey findings and literature review a third category; collaboration-related principles were defined in this research. As shown in Table 5.2, five principles i.e. CDM, EIKP, JDPTC, ID and FT, listed as contractual principles according to NASFA et al (2010) and AIA (2012) are classified as collaboration- related principles. It was observed that although, it is beneficial to add these principles in contracts, these principles can be implemented to a large extent by means of technological (ICT related) and organizational measures and thus can be distinguished from the other two principles (SRR and LWKP) 
that are purely contractual related principles. Apart from this, the classification used in this research also includes the three defined behavioral principles.

Table 5.2 Evolution of IPD Definition

\begin{tabular}{|l|l|l|}
\hline $\begin{array}{c}\text { IPD Characteristics } \\
\text { (previous) } \\
\text { AIA (2010) } \\
\text { Used in Survey }\end{array}$ & \multicolumn{1}{c|}{$\begin{array}{c}\text { IPD Principles } \\
\text { (recent) } \\
\text { AIA (2012) }\end{array}$} & $\begin{array}{c}\text { Selected for IPD- } \\
\text { Readiness Assessment } \\
\text { Model }\end{array}$ \\
\hline MPC & KPBTE - Contractual & X Not selected \\
\hline SRR & SRR - Contractual & $\checkmark \quad$ Contractual \\
\hline LWKP & LWKP - Contractual & $\checkmark \quad$ Contractual \\
\hline CDMC & CDM - Contractual & $\checkmark \quad$ Collaboration \\
\hline EIKP & EIKP - Contractual & $\checkmark \quad$ Collaboration \\
\hline JDVG & JDPTC - Contractual & $\checkmark \quad$ Collaboration \\
\hline & ID - Contractual & $\checkmark \quad$ Collaboration \\
\hline & FT - Contractual & $\checkmark \quad$ Collaboration \\
\hline & MRT - Behavioral & $\checkmark \quad$ Behavioral \\
\hline & WTC - Behavioral & $\checkmark \quad$ Behavioral \\
\hline & OC - Behavioral & $\checkmark \quad$ Behavioral \\
\hline & &
\end{tabular}

Based on the above classification, a measuring scale has been developed for each the ten selected IPD principles. These scales varies from 0 (zero) to 10 (ten). Where zero means that the project is not IPD ready and ten means it is fully IPD ready. The scale for each of the principles is dependent on the various dimensions of that particular principle. It is also important to mention that these scales measure the readiness of IPD principles are not dependent of ICT use of the project. Following is the brief discussion on the development of IPD readiness scales for each of the IPD Principle. 


\subsubsection{EARLY INVOLVEMENT OF KEY PARTICIPANTS (EIKP)}

"Projects have become increasingly complex. Requiring all participants essential to project success to be at the table early allows greater access to pools of expertise and better understanding of probable implications of design decisions" (NASFA et. al. 2010).

Based on the above-mentioned description EIKP readiness scores are calculated based on the time of entry of project participants to the project. Highest readiness score (10) indicates that the project team formation (including $\mathrm{A} / \mathrm{E}$, contractor and subcontractors) took place early during the programming phase of project. The score for EIKP decreases as the project progresses through design phases and becomes zero if the project team is not formed until construction phase. Following Table 5.3 shows the scale for EIKP

It should be noted that, in case where time of entry of the project participants is different from define points on scale, the score can be assigned according to best suited point on scale. For example, If majority of participants are present at detailed design phase (A/E, contractor and owner), score 5 can be assigned.

Table 5.3 Scoring Mechanism for EIKP

\begin{tabular}{|l|l|l|l|l|}
\hline \multicolumn{5}{|c|}{ IPD Readiness score for EIKP } \\
\hline $\mathbf{1 0}$ & \multicolumn{1}{|c|}{$\mathbf{7 . 5}$} & \multicolumn{1}{|c|}{$\mathbf{5}$} & \multicolumn{1}{c|}{$\mathbf{2 . 5}$} & \multicolumn{1}{c|}{$\mathbf{0}$} \\
\hline $\begin{array}{l}\text { If all key } \\
\text { participants are } \\
\text { present at } \\
\text { programming } \\
\text { phase }\end{array}$ & $\begin{array}{l}\text { if all key } \\
\text { participants are } \\
\text { present at } \\
\text { schematic design } \\
\text { phase }\end{array}$ & $\begin{array}{l}\text { if all key } \\
\text { participants are } \\
\text { present at } \\
\text { detailed design } \\
\text { phase }\end{array}$ & $\begin{array}{l}\text { if all key } \\
\text { participants are } \\
\text { present at } \\
\text { construction } \\
\text { documentation } \\
\text { phase }\end{array}$ & $\begin{array}{l}\text { fontractor and } \\
\text { sub contractor } \\
\text { joins the project } \\
\text { team at } \\
\text { construction } \\
\text { phase }\end{array}$ \\
\hline
\end{tabular}




\subsubsection{COLLABORATIVE DECISION-MAKING (CDM)}

"Requiring key project participants to work together on important decisions leverages pools of expertise and encourages joint accountability" (NASFA et. al. 2010) .

The scoring measurement for CDM is based on two dimensions (1) Which of the project participants giving their input on important decision points and (2) Which participants are the final decision makers. The score is highest (10) when all project participants (Owners, $\mathrm{A} / \mathrm{E}$, Contractor and related sub contractors) are involved in both giving inputs and making final decisions. The score decreases with the participation level as explained in Table 5.4 below and becomes zero when the decisions are made on the sole discretion of either owner, $\mathrm{A} / \mathrm{E}$ or contractor based on the particular project phase.

Table 5.4 Scoring Mechanism for CDM

\begin{tabular}{|c|c|c|c|c|}
\hline \multicolumn{5}{|c|}{ IPD Readiness score for CDM } \\
\hline 10 & 7.5 & 5 & 2.5 & $\mathbf{0}$ \\
\hline $\begin{array}{l}\text { When Input is } \\
\text { taken from all key } \\
\text { participants and } \\
\text { also all } \\
\text { participants are } \\
\text { involved in } \\
\text { decision making }\end{array}$ & $\begin{array}{l}\text { When all key } \\
\text { participants } \\
\text { provide input } \\
\text { while final } \\
\text { decision makers } \\
\text { are Owners, A/E, } \\
\text { and Contractor }\end{array}$ & $\begin{array}{l}\text { When input is } \\
\text { taken from } \\
\text { Owners, } \mathrm{A} / \mathrm{E} \text {, and } \\
\text { Contractor and } \\
\text { also same } \\
\text { participants are } \\
\text { involved in } \\
\text { decision making }\end{array}$ & $\begin{array}{l}\text { When Input is } \\
\text { taken from } \\
\text { Owners, A/E, and } \\
\text { Contractor while } \\
\text { decision makers } \\
\text { are either only } \\
\text { owner /A/E or } \\
\text { contractor. }\end{array}$ & $\begin{array}{l}\text { When major } \\
\text { decisions are } \\
\text { made on sole } \\
\text { discretion of } \\
\text { either owners/A/E } \\
\text { or Contractor, } \\
\text { without input } \\
\text { from other project } \\
\text { participants }\end{array}$ \\
\hline
\end{tabular}

\subsubsection{INTENSIFIED DESIGN (ID)}

"The cost of changes to projects increases in relation to time. Greater team investment in design efforts prior to construction allows greater opportunities for cost control as well as enhanced ability to achieve all desired project outcomes" (NASFA et. al. 2010). 
The scores for intensified design are measured based on the level of team investment in the design efforts. Team investment can be defined as a function of team members available at the time of design and level of participation (frequency of meetings) of the team. Time of design is further divided into typical phases of design in a construction project i.e. Schematic Design (SD), Detailed Design (DD) and Construction Documentation (CD).

The highest team investment in design efforts (Score 10) is when all project participants (Owners, A/E, Contractor and sub contractors) are involved right from the SD phase of project and meet at regular short intervals (at least once a week) and to cater any special needs of the design such as design clashes. The score decreases with the late involvement of participants. It is assumed that $\mathrm{A} / \mathrm{E}$ and Owners are always present during design phase; therefore, level of participation is measured in terms of contractor and sub contractors participation at different phases of design. Also the score decreases if the team meetings are not regular and only held in result of some design clashes. Based on this score following Table 5.5 shows the scores of ID.

Table 5.5 Scoring Mechanism for ID

\begin{tabular}{|l|l|l|l|l|}
\hline \multicolumn{5}{|c|}{ IPD Readiness score for ID } \\
\hline 10 & \multicolumn{1}{|c|}{$\mathbf{7 . 5}$} & \multicolumn{1}{|c|}{$\mathbf{5}$} & \multicolumn{1}{|c|}{$\mathbf{2 . 5}$} & 0 \\
\hline $\begin{array}{l}\text { When all key } \\
\text { participants are } \\
\text { involved in design } \\
\text { from the SD } \\
\text { phase and meet } \\
\text { regularly }\end{array}$ & $\begin{array}{l}\text { When all key } \\
\text { participants are } \\
\text { available at DD } \\
\text { phase and meet } \\
\text { regularly }\end{array}$ & $\begin{array}{l}\text { When all key } \\
\text { participants are } \\
\text { involved in design } \\
\text { from the SD phase } \\
\text { but meetings are only } \\
\text { held at the time of } \\
\text { design clashes. }\end{array}$ & $\begin{array}{l}\text { When all key } \\
\text { participants are } \\
\text { available at DD } \\
\text { phase and but } \\
\text { meetings are only } \\
\text { held at the time of } \\
\text { design clashes. }\end{array}$ & $\begin{array}{l}\text { Contractor and } \\
\text { present during } \\
\text { the design phase) }\end{array}$ \\
\hline
\end{tabular}




\subsubsection{JOINTLY DEVELOPED PROJECT TARGET CRITERIA (JDPTC)}

"Carefully defining project performance criteria with the input support and buy-in of all key participants ensures maximum attention will be paid to the project in all dimensions deemed important" (NASFA et. al. 2010).

The scale for scoring JDPTC is similar to the developed scale of CDM. The score is highest (10) when all project participants (Owners, A/E, Contractor and also related sub contractors) are involved in both giving inputs and developing project target criteria and is minimum (zero) when target criteria are set without input from contractors and subcontractors. The intermediate points on scale are defined in Table 5.6.

Table 5.6 Scoring Mechanism for JDPTC

\begin{tabular}{|c|c|c|c|c|}
\hline \multicolumn{5}{|c|}{ IPD Readiness score for JDPTC } \\
\hline 10 & 7.5 & 5 & 2.5 & 0 \\
\hline $\begin{array}{l}\text { When input is } \\
\text { taken from all key } \\
\text { participants and } \\
\text { also all } \\
\text { participants are } \\
\text { involved in } \\
\text { devising project } \\
\text { target criteria }\end{array}$ & $\begin{array}{l}\text { All key } \\
\text { participants } \\
\text { provide input } \\
\text { while final project } \\
\text { target criteria are } \\
\text { developed by } \\
\text { Owners, A/E, and } \\
\text { Contractor }\end{array}$ & $\begin{array}{l}\text { When input is } \\
\text { taken from } \\
\text { Owners, A/E, and } \\
\text { Contractor and } \\
\text { also same } \\
\text { participants } \\
\text { develops project } \\
\text { target criteria }\end{array}$ & $\begin{array}{l}\text { When input is } \\
\text { taken from } \\
\text { Owners, } \mathrm{A} / \mathrm{E} \text {, and } \\
\text { Contractor while } \\
\text { project target } \\
\text { criteria are set by } \\
\text { only Owners } \\
\text { and/or A/E }\end{array}$ & $\begin{array}{l}\text { Project target } \\
\text { criteria are based } \\
\text { on inputs of } \\
\text { owners and/or } \\
\text { A/E, without } \\
\text { consulting from } \\
\text { other project } \\
\text { participants }\end{array}$ \\
\hline
\end{tabular}

\subsubsection{FISCAL TRANSPARENCY (FT)}

"Requiring and maintaining an open book environment increases trust and keeps contingencies visible — and controllable" (NASFA et. al. 2010).

The score for FT are based on maintaining open books and access to records. The minimum condition for open book is that contractually $\mathrm{A} / \mathrm{E}$ and all its consultants, general contractor, and its sub contractors are required to keep open books. In practice, however it is observed that GSA (public owner) also maintained an open book (called 
reverse open book). The second dimension of this is related to transparency, which is measured in terms of access of the records to project team members (project management team). Base on the discussion following is the Table 5.7 with scoring criteria for measuring FT.

Table 5.7 Scoring Mechanism for FT

\begin{tabular}{|c|c|c|c|c|}
\hline \multicolumn{5}{|c|}{ IPD Readiness score for FT } \\
\hline 10 & 7.5 & 5 & 2.5 & 0 \\
\hline $\begin{array}{l}\text { Open books are } \\
\text { maintained by all } \\
\text { project } \\
\text { participants } \\
\text { including owners } \\
\text { and all project } \\
\text { participants have } \\
\text { access to records. }\end{array}$ & $\begin{array}{l}\text { Open books are } \\
\text { maintained by all } \\
\text { project } \\
\text { participants } \\
\text { excluding owners } \\
\text { and all project } \\
\text { participants have } \\
\text { access to records }\end{array}$ & $\begin{array}{l}\text { Open books are } \\
\text { maintained by all } \\
\text { project participants } \\
\text { excluding owners } \\
\text { and Owner, A/E and } \\
\text { Contractor have } \\
\text { access to records. }\end{array}$ & $\begin{array}{l}\text { Open books are } \\
\text { maintained by all } \\
\text { project } \\
\text { participants } \\
\text { excluding owners } \\
\text { and only Owner, } \\
\text { has access to } \\
\text { records. }\end{array}$ & $\begin{array}{l}\text { Open book } \\
\text { keeping is not } \\
\text { contractually } \\
\text { required on the } \\
\text { project. }\end{array}$ \\
\hline
\end{tabular}

\subsubsection{LIABILITY WAIVERS BETWEEN KEY PARTICIPANTS (LWKP)}

"When project participants agree not to sue one another, they are generally motivated to seek solutions to problems rather than assigning blame" (NASFA et. al. 2010).

The scoring mechanism for LWKP is based on the participants involved in the setup and the level of waiving or limiting the liabilities between each other. It should be noted that even when all project participants (including Owners, A/E, Contractor and Subcontractors) waive all general liabilities; it does not generally include claims for willful misconduct, unfulfilled warranty obligations, or failure to procure insurance. An alternative to complete waiver of claims and liabilities, where not practically possible, is to limit the consequential damages to a predetermined amount (which is usually the fee of the particular professional). The project is not IPD ready related LWKP principle if none 
of the claims and liabilities can be waived. Based on this the scoring mechanism for measuring LWKP readiness is presented in Table 5.8.

Table 5.8 Scoring Mechanism for LWKP

\begin{tabular}{|c|c|c|c|c|}
\hline \multicolumn{5}{|c|}{ IPD Readiness score for $L W K P$} \\
\hline 10 & 7.5 & 5 & 2.5 & $\mathbf{0}$ \\
\hline $\begin{array}{l}\text { All participants } \\
\text { waive all general } \\
\text { claims against } \\
\text { each other. }\end{array}$ & $\begin{array}{l}\text { Owners, } \mathrm{A} / \mathrm{E} \text { and } \\
\text { Contractor waive } \\
\text { all general claims } \\
\text { against each } \\
\text { other. }\end{array}$ & $\begin{array}{l}\text { Only } \mathrm{A} / \mathrm{E} \text { and } \\
\text { Contractor waive } \\
\text { all general claims } \\
\text { against each } \\
\text { other. }\end{array}$ & $\begin{array}{l}\text { Limiting } \\
\text { consequential } \\
\text { damages to the } \\
\text { predetermined } \\
\text { amount between } \\
\text { Owner and A/E or } \\
\text { Contractor. }\end{array}$ & $\begin{array}{l}\text { No specific limit } \\
\text { on liability or } \\
\text { "no-sue" clause in } \\
\text { the contracts. }\end{array}$ \\
\hline
\end{tabular}

It should be noted that the arrangement of liabilities limitation and waiver can vary from case to case. The scoring mechanism addresses the best and the worst case and three continuous points in between. The scores can be assigned to each project based on the closeness to the defined points on scale.

\subsubsection{SHARED FINANCIAL RISK AND REWARD BASED ON PROJECT} OUTCOME (SRR)

"Tying fiscal risk and reward to overall project outcomes rather than individual contribution encourages participants to engage in "best for project" behavior rather than best for stakeholder thinking" (NASFA et. al. 2010).

The scoring mechanism for SRR is based on (1) which participants are involved in risk and reward sharing mechanism. Where SRR is implemented in its true sense, the risk sharing participants put a percentage of their profit at risk to partially fund cost overruns, or other project liabilities if any occurred and incentivized for achieving project 
goals developed according to the target criteria. The targets can only be cost related or can be extended to other performance goals such as schedule, quality, sustainability etc. According to this, the SRR readiness score would be highest (10) if all project participants are sharing the risks and putting their profits on stake for achieving both the project target criteria. The scores will decrease with lesser number of participants involved in SRR arrangement. A lesser score (2.5) is associated with the scenario although risks are not contractually shared, the project participants are incentivized for achieving preset performance criteria. The scale is presented below in Table 5.9.

Table 5.9 Scoring Mechanism for SRR

\begin{tabular}{|c|c|c|c|c|}
\hline \multicolumn{5}{|c|}{ IPD Readiness score for SRR } \\
\hline 10 & 7.5 & 5 & 2.5 & $\mathbf{0}$ \\
\hline $\begin{array}{l}\text { Risks and rewards } \\
\text { are shared } \\
\text { between all } \\
\text { project } \\
\text { participants. }\end{array}$ & $\begin{array}{l}\text { Risks and rewards } \\
\text { are shared with } \\
\text { A/E and } \\
\text { contractor. }\end{array}$ & $\begin{array}{l}\text { Risks and rewards } \\
\text { are shared with } \\
\text { contractor only. }\end{array}$ & $\begin{array}{l}\text { Rewards for pre } \\
\text { defined } \\
\text { performance } \\
\text { targets are shared } \\
\text { with A/E and/or } \\
\text { contractor. }\end{array}$ & $\begin{array}{l}\text { No agreed } \\
\text { arrangement for } \\
\text { shared risks and } \\
\text { /or reward } \\
\text { between the } \\
\text { project } \\
\text { participants }\end{array}$ \\
\hline
\end{tabular}

\subsubsection{MUTUAL RESPECT AND TRUST (MRT)}

"Nurturing a positive environment requires deep appreciation for the motivations of all project participants: if they do not operate in an environment of mutual respect and trust, performance erodes and participants retreat to "best for stakeholder" behaviors" (NASFA et. al. 2010).

To provide the right environment for mutual respect and trust, efforts are required from the beginning of the team selection process and should be continued throughout the project phases. Record of accomplishment is an essential tool to judge the other party's 
competence and consistency level. The team-forming process considers not only complementary resources and capabilities of potential partners, but also the interrelationships between partners and the client.

Past working experience between the team members as a unit also strengthens the mutual trust and respect between them. All participants having an experience working as a team will be an ideal case. However, for developing the scale, past experience is rated high if all three major participants (A/E, contractor and Owner) have a joint past working experience or a combination of experience where $\mathrm{A} / \mathrm{E}$ and contractor have a joint working experience and Owner has experience of working with at least one of them. In similar manner following combinations are made to define the high, medium and low experience; Owner $+\mathrm{AE}+$ Contractor $(\mathrm{A}), \mathrm{AE}+$ Contractor $(\mathrm{B})$, Owner $+\mathrm{A} / \mathrm{E}(\mathrm{C})$, Owner + Contractor (D). Table 5.10 represents the level of team participation for several combinations of past working experience.

Table 5.10 Classification of Prior Team Experience

\begin{tabular}{|l|c|c|c|c|c|c|}
\hline $\begin{array}{l}\text { Teams' prior experience as } \\
\text { a unit }\end{array}$ & High & High & High & Medium & Low & Low \\
\hline Team combinations & $\mathrm{A}$ & $\mathrm{B}+\mathrm{C}$ & $\mathrm{B}+\mathrm{D}$ & $\mathrm{B}$ & $\mathrm{C}$ & $\mathrm{D}$ \\
\hline
\end{tabular}

The third dimension considered for the MRT is the use trust-building workshops during project phases (Constructing Excellence 2004). For setting up the scale, first priority is given to activity related to current project i.e. trust-building workshops, next priority is given to past working exp as group and then to trust competence as selection criteria. The scoring scale for measuring MRT readiness is as follows in Table 5.11. 
Table 5.11 Scoring Mechanism for MRT

\begin{tabular}{|c|c|c|c|c|}
\hline \multicolumn{5}{|c|}{ IPD Readiness score for MRT } \\
\hline 10 & 7.5 & 5 & 2.5 & $\mathbf{0}$ \\
\hline $\begin{array}{l}\text { Trust-building } \\
\text { workshops were } \\
\text { conducted during } \\
\text { the project } \\
\text { phases, team has } \\
\text { high prior } \\
\text { working } \\
\text { experience and } \\
\text { trust competence } \\
\text { was considered as } \\
\text { selection criteria }\end{array}$ & $\begin{array}{l}\text { Trust-building } \\
\text { workshops were } \\
\text { conducted during } \\
\text { the project } \\
\text { phases, team has } \\
\text { high prior } \\
\text { working } \\
\text { experience and } \\
\text { trust competence } \\
\text { was not } \\
\text { considered as } \\
\text { selection criteria. }\end{array}$ & $\begin{array}{l}\text { Trust-building } \\
\text { workshops were } \\
\text { not conducted } \\
\text { during the project } \\
\text { phases, team has } \\
\text { medium prior } \\
\text { working } \\
\text { experience and } \\
\text { trust competence } \\
\text { was considered as } \\
\text { selection criteria }\end{array}$ & $\begin{array}{l}\text { Trust-building } \\
\text { workshops were } \\
\text { not conducted } \\
\text { during the project } \\
\text { phases, team has } \\
\text { medium prior } \\
\text { working } \\
\text { experience and } \\
\text { trust competence } \\
\text { was not } \\
\text { considered as } \\
\text { selection criteria }\end{array}$ & $\begin{array}{l}\text { Trust-building } \\
\text { workshops were } \\
\text { not conducted } \\
\text { during the project } \\
\text { phases team has } \\
\text { no working } \\
\text { experience and } \\
\text { trust competence } \\
\text { was not } \\
\text { considered as } \\
\text { selection criteria }\end{array}$ \\
\hline
\end{tabular}

\subsubsection{WILLINGNESS TO COLLABORATE (WTC)}

"Collaboration is ultimately a behavioral choice. It is important to nurture an environment that supports and encourages participants to choose to collaborate" (NASFA et. al. 2010).

The dimensions effecting the scale for readiness related to willingness to collaborative are (1) alignment of goals and (2) interaction opportunities between the team members. Alignment of goals is achieved when project team jointly develops project goals and shares the risks and rewards of achieving the goals. The interaction is fully open when strategies like collocation, BIG rooms are adapted to facilitate collaboration, partially open when interaction strategies are limitedly used (for example partial co-location for a specific period or group members), and there is a disconnect when the project participants work from their own offices (silos) with little interactions between them. Based on these two dimensions the willingness to collaborate can be scales as shown in Table 5.12. 
Table 5.12 Scoring Mechanism for WTC

\begin{tabular}{|c|c|c|c|c|}
\hline \multicolumn{5}{|c|}{ IPD Readiness score for WLC } \\
\hline 10 & 7.5 & 5 & 2.5 & $\mathbf{0}$ \\
\hline $\begin{array}{l}\text { Goals are aligned } \\
\text { and interaction } \\
\text { between the } \\
\text { participants is } \\
\text { open }\end{array}$ & $\begin{array}{l}\text { Goals are aligned } \\
\text { but interaction } \\
\text { between the } \\
\text { participants is } \\
\text { partially open }\end{array}$ & $\begin{array}{l}\text { Goals are not } \\
\text { aligned but the } \\
\text { interaction } \\
\text { between the } \\
\text { participants is } \\
\text { open }\end{array}$ & $\begin{array}{l}\text { Goals are not } \\
\text { aligned but the } \\
\text { interaction } \\
\text { between the } \\
\text { participants is } \\
\text { partially open }\end{array}$ & $\begin{array}{l}\text { Goals are not } \\
\text { aligned and there } \\
\text { is a physical } \\
\text { disconnect } \\
\text { between the } \\
\text { participants. }\end{array}$ \\
\hline
\end{tabular}

\subsubsection{OPEN COMMUNICATION (OC)}

"Collaboration requires open, honest communication: if project participants are reluctant to share ideas or opinions, opportunities for innovation and improvement may be missed" (NASFA et. al. 2010).

Openness of communication for this scale is measured through (1) nature of interdisciplinary communication and (2) frequency of meetings between the project participants. The ideal lines of communication between the participants are direct formally (i.e. contractually all participants are allowed to communicate with each other without any restriction). A less open alternative to that is an arrangement where although contractual language explicit long transmission chain of communication (for example communication between owner and contractors has to be through $\mathrm{A} / \mathrm{Es}$ ), the observed communication lines are more relaxed and less restrictive (informally open). The most restrictive lines of communications are found where the correspondence between the project participants is formally and actually routed through a long transmission chain. For example any communication between owner and contractor has to channel through the architect with no direct communication between owner and contractor. 
Another factor effecting the open communication is the meeting frequency between the team members. High meeting frequency relates to more frequent regular meetings between the participants and additional special purpose meetings to cater any critical issues that cannot wait for weekly meetings to resolve. These meetings provide opportunities for better and common understanding of the project between the project participants and sharing of innovative ideas. Low frequency relates to meetings only during critical times. Based on these two dimensions Table 5.13 provides the IPD readiness score for OC.

Table 5.13 Scoring Mechanism for OC

\begin{tabular}{|l|l|l|l|l|}
\hline \multicolumn{5}{|c|}{ IPD Readiness score for OC } \\
\hline \multicolumn{1}{|c|}{$\mathbf{1 0}$} & \multicolumn{1}{|c|}{$\mathbf{7 . 5}$} & \multicolumn{1}{c|}{$\mathbf{5}$} & \multicolumn{1}{c|}{$\mathbf{2 . 5}$} & \multicolumn{1}{c|}{$\mathbf{0}$} \\
\hline $\begin{array}{l}\text { Communication } \\
\text { flow is formally } \\
\text { open and direct, } \\
\text { frequency of } \\
\text { meetings is high }\end{array}$ & $\begin{array}{l}\text { Communication } \\
\text { flow is informally } \\
\text { open, frequency } \\
\text { of meetings is } \\
\text { high. }\end{array}$ & $\begin{array}{l}\text { Communication } \\
\text { flow is formally } \\
\text { open and direct, } \\
\text { frequency of } \\
\text { meetings is low }\end{array}$ & $\begin{array}{l}\text { Communication } \\
\text { flow is restrictive } \\
\text { and routes } \\
\text { through long } \\
\text { transmission } \\
\text { chain, frequency } \\
\text { of meetings is } \\
\text { high. }\end{array}$ & $\begin{array}{l}\text { Communication } \\
\text { flow is restrictive } \\
\text { and routes } \\
\text { through long } \\
\text { transmission } \\
\text { chain, frequency } \\
\text { of meetings is } \\
\text { low }\end{array}$ \\
\hline
\end{tabular}

This concludes the scaling mechanism for the ten selected principles. In the following section the ICT push and IPD pull concepts are discussed in order to distinguish the principles that can be facilitated by the use of ICT tools and methods.

\subsection{ICT PUSH AND IPD PULL CONCEPTS}

The major purpose of developing ICT push IPD pull classification is to identify principles that can be fostered to a higher extent using ICT tools and methods as well as identify which of the IPD principles provide opportunities for increased use of ICT tools. 


\subsubsection{ICT PUSH TO IPD PRINCIPLES}

It can be defined as the capability of ICT tools and methods to develop desirable conditions for implementation of IPD principles. In other words certain IPD principles can be implanted to higher extent in presence of supporting ICT tools and methods. For example, visualization of form through BIM facilitates the project participants to make more collaborative decisions.

In the following discussion the IPD principles identified as predominantly ICT push principles are identified and major reasons for their classification are explicated.

\subsubsection{ICT PUSH TO CDM}

ICT tools and methods can assist the decision-making tasks by delivering the required levels of "consistency and reliability" of information by the project team to make decisions (Ahuja et al. 2009). For example quick and real-time updates in the cost and schedule allows the project participants to make more collaborative decisions based on more precise information.

\subsubsection{ICT PUSH TO ID}

The quality of design is based on the inputs and participation of the project participants during the development of design. These dimensions can be facilitated through effective ICT tools and methods. Design reviews and analysis are conducted throughout the design phase to provide better understanding of the design to all project participants. There is a great potential for ICTs to facilitate these major tasks of design phase. For 
example, visualization of forms and virtual walk through of the building can facilitate owner's input to design and thus facilitate ID.

\subsubsection{ICT PUSH TO JDPTC}

Project targets are developed early during the project lifecycle based on limited information. ICT tools and methods can facilitate JDPTC by allowing efficient processing of the project information. For example, tools such as Vico Office, can assist the development of more accurate cost and schedules right from the beginning of the project by providing linkages between the building model and the relevant cost indexes and historical cost parameters and by allowing automated material quantity take offs. Thus project team can benefit from such ICT systems that improves the delivery process by facilitating the project participants to confidently develop the project target criteria and aligned goals (Ibrahim et al. 2013).

\subsubsection{ICT PUSH TO FT}

Fiscal transparency depends upon the open-book record keeping maintained on the project by all project participants including consultants and subcontractors. The transparency of these records can be greatly enhanced by allowing project participants electronic access to financial records. This allows flow of finances to become clear and transparent to project team. For example a central project management information system (such as $\mathrm{CMiC}$ ) that assures electronic access the financial records facilitates the principle of FT (AIA 2010). 


\subsubsection{ICT PUSH TO WTC}

Willingness to collaborate is effected by the team integration and alignment of interest of project participants. ICT tools and methods has the capability to increase integration between project participants by facilitating interactions between the team members. Many researchers believe that willingness to collaborate can be increased by effective use of ICT tools and methods. Alshawi and Faraj (2002) highlighted that the use of ICT systems in projects is considered a significant element in developing integrated construction environments between project participants (2002). El-Gohary \& El Diraby (2009) also advocated the use ICT systems to enhance the collaboration efforts on the project and suggested that ICT tool like portal based system will encourage improved communication, coordination, and collaboration among the project team members.

\subsubsection{ICT PUSH TO OC}

Open communication should allow collaboration and sharing of information, ideas and honest opinion between the project participants without any hesitation. The ideal way to communicate is face-to-face; however, it is not always practical. In such situations, a wide range of ICT tools can facilitate the open communication at several levels. Email, conference calls, networked project management site, SMART Boards, BIM collaborative tools are just few examples of the ICTs that can support communication between the project participants. Evidences of use of these ICT tools and methods in case studies published by AIA (2012) were found to be effective in increasing the openness of communication between the project participants. 


\subsubsection{IPD PULL TO ICT USE}

IPD pull can be defined as the increased opportunities for higher and efficient use of ICT tools due to the presence of particular IPD principles. In other words, the presence of certain IPD principles facilitates the use of ICT tools and methods. For example, early involvement of key participants can increase opportunities for virtual meetings between project participants and thus web conferencing tools can be used more in such a setup.

In the following discussion, IPD pull principles are highlighted. It should be noted that all IPD principles (including ICT push principles) have some degree of IPD pull associated with them. However, the principles listed below are categorized as IPD pull principles based on their predominant characteristics to attract ICT tools.

\subsubsection{MRT PULL TO ICT}

Working environment that establishes mutual trust between the project participants allows for successful use of ICT tools (Kajewski et al. 2001). Mutual respect and trust is a pre requisite to information sharing and integration of systems within the project participants (Cheng et al. 2010). Thus it can be said that the IPD principle provides the required pull to facilitate the effective use of ICT tools and methods. Briscoe and Dainty (2005) elucidated the lack of trust as one of the most important cause of failure of information flow between the project participants.

\subsubsection{EIKP PULL TO ICT}

EIKP allows several project participants to collaborate on the project earlier than the traditional. This early involvement not only brings the expertise and valuable insight 
of the construction phase to the design phase but also demands the higher use of ICT tools and methods to meet the demands of collaborative environment. One example of benefits of EIKP that enhanced the use of ICT tool (BIM) can be quoted from Sutter Health Fairfield Medical Office Building where early involvement of subcontractors allowed identification of over 400 system clashes which according to contractor's representative, "provided significant cost savings due to increased field productivity, tighter schedule, more prefabricated work, and less redesign”.

\subsubsection{LWKP PULL TO ICT}

Liability waivers are primarily limited to foster the innovation and creativity in the project team. Collaborative design process includes participants from various disciplines that share innovative ideas. Liability waivers promote communication and collaboration by eliminating the fear of claims due to sharing of innovative (untested) ideas (Cleves Jr. and Gallo 2012). The increased collaboration efforts demands increased use of ICT tools thus LWKP pulls ICT.

\subsubsection{SRR PULL TO ICT}

By sharing the risks and rewards, the project participants are accepting that the uncertainties and complexities of the project need to be mutually managed. This requires constructive and efficient communication between the participants at both formal and informal levels. (Lehtiranta 2011). These intensive communication needs actually creates the need for more use of ICT tools on the collaborative project. 
To summarize these two concepts, Table 5.14 classifies the IPD principles under ICT push and IPD pull criteria. It should be noted that all the ICT push principles are either collaboration or behavioral principles. The IPD pull principles consists of two contractual principles and one of each collaborative and behavioral principles. The reason for EIKP and MRT listed as IPD pull principles is that while ICT tools and methods cannot ensure these principles, the presence of early involvement of key participants and mutual respect and trust can greatly enhance the use of ICTS.

Table 5.14 Classification of IPD Principles

\begin{tabular}{|c|c|}
\hline ICT PUSH & IPD PULL \\
\hline CDM & EIKP \\
\hline ID & LWKP \\
\hline JDPTC & SRR \\
\hline FT & MRT \\
\hline WTC & \\
\hline OC & \\
\hline
\end{tabular}

After classifying the IPD principles the next step is to determine the impact of ICT tools and methods on the readiness of the ICT push IPD principles. To determine this, first the levels of ICT use are defined. Following section discusses these levels.

\subsection{LEVELS OF ICT USE}

With the passage of time, the reliance of construction industry on ICT applications and tools has increased. Froese (2010) divided the evolution of ICT in construction industry in the following three phases. Initial focus of ICT in construction, 
about four decades ago, was on developing applications to assist operations that were manually performed initially. For example, development of CAD to replace manual drafting, use of spreadsheets to calculate quantities of materials, cost calculations etc. (Nikas et al. 2007). These applications are now well recognized and matured within current practice. Second era of advancements (from the mid-1990s) focused on electronic communications such as E-mail, electronic document management (EDM) etc. This phase is less matured as compared to the first with new embellishments still emerging and business processes are adapting to developments. The latest phase (from mid 2000s) has focused on the potential for integration all of these scattered applications into an overall system, for example BIM. This phase of ICT advancements in construction has great potential to improve the industry but has to reach mainstream application (Froese 2010).

For this research, the use of ICT tools and methods in a construction project is looked from three different aspects. One very straightforward classification of ICT levels considered was based on the sophistication of ICT tools and methods where the three progressive levels defined were low-tech, medium-tech and hi-tech. For example, costestimating tools limited to spreadsheets with mostly manual inputs are very basic tools and can be regarded as Low -Tech tool. As compared to this, If CAD driven quantities can be linked to cost estimating functions and changes can be updated as occurs it is an advanced level of ICT however advancements are still possible which makes it a Medium-Tech tool. A Hi-tech set of tool in the same area is being a 5D BIM, which does 
not only have the medium-tech capabilities but also is capable of linking cost estimating to time and constructability analysis (Staub-French and Khanzode 2007).

Impact of ICT tools and methods were also considered. Ahmad et al. (2010) classified the use of ICT tools and methods based on their impact to achieve informational, organizational and contractual integration. According to this classification, an information system can serve at several levels to achieve integration. The lowest level in this classification is information integration that may be explained by BIM that provides electronic linkages between construction applications, such as, estimating, scheduling, cost control. Organization integration on this scale can be exemplified as BIM that combines engineering, procurement, and construction activities suggesting electronic file exchanges between architectural, engineering, contracting and supply activities the highest level of integration i.e. contractual can be achieved using BIM that promotes paperless documentation giving rise to less bureaucratic inter-organizational relationships.

Another approach for classification of ICTs considered was the use of ICT tools and methods to facilitate management, processing and communication of information (Ahmad et al. 1995). Information management includes capturing, storing, organizing, and retrieving data. Shared databases, data warehousing, are examples of information management systems (Ahmad and Ahmed, 2001). Processing includes all systems and models developed for processing data. The most common examples include resource management and project cost control using shared databases through Internet 
(Skibniewski and Abduh, 2000). Communications includes all aspects of communicating data and information such as text, graphics, audio and video.

Based on this understanding, the levels of ICT have been defined for this research under three levels I, II and III. Example of each of the considered aspect of ICT dimensions are defined in Table 5.15.

Table 5.15 Levels of ICT Tools and Methods

\begin{tabular}{|l|l|l|l|}
\hline \multicolumn{1}{|c|}{ Criteria } & \multicolumn{1}{c|}{ Level I } & \multicolumn{1}{c|}{ Level II } & \multicolumn{1}{c|}{ Level III } \\
\hline Sophistication & Low-tech & Medium-tech & Hi-tech \\
\cline { 2 - 4 } & 2D CAD & 3D CAD & BIM \\
\hline Impact & $\begin{array}{l}\text { Informational } \\
\text { Integration }\end{array}$ & $\begin{array}{l}\text { Organizational } \\
\text { Integration }\end{array}$ & Contractual Integration \\
\cline { 2 - 4 } & $\begin{array}{l}\text { CMiC for Internal } \\
\text { management of } \\
\text { RFIs }\end{array}$ & $\begin{array}{l}\text { CMiC used for } \\
\text { external management } \\
\text { of RFIs }\end{array}$ & $\begin{array}{l}\text { BIM model capturing and } \\
\text { sharing RFIs and reducing the } \\
\text { need of separate PMIS }\end{array}$ \\
\hline $\begin{array}{l}\text { Use of } \\
\text { Information }\end{array}$ & Management & Processing & Communication \\
\cline { 2 - 5 } & Database system & $\begin{array}{l}\text { Decision support } \\
\text { system }\end{array}$ & Groupware \\
\hline
\end{tabular}

For defining the ICT levels, the construction project was divided into the programming, schematic design, detail development, construction document and construction phase. The reason for limiting the phases to the construction phase is that integrated project delivery readiness is measured based on pre construction and construction phases and thus ICT push is also determined for the same phases. However, it should be noted that this assumption does not neutralize the importance of ICT use in post contraction phases of start-up and operation. In fact, the use of ICT (especially BIM) is rapidly gaining popularity for facilities management (Sabol, 2008). 
Several functions have been identified under each project phase that describe the major tasks that are performed under the phase. The list of all project functions is provided in Table 5.16. It can be noted that the major tasks performed in the design phases are similar, however they differ in the level of details that can potentially affects the tools utilized to perform these task.

Table 5.16 List of Project Functions

\begin{tabular}{|l|l|}
\hline Symbol & Functions \\
\hline & Programming \\
\hline P1 & Development and selection of preliminary project concept. \\
\hline P2 & Development of preliminary cost. \\
\hline P3 & Development of preliminary schedule. \\
\hline & Schematic Design \\
\hline SD1 & Development of drawings and documents. \\
\hline SD2 & Development of specifications. \\
\hline SD3 & Development of cost estimates and schedules. \\
\hline SD4 & Design review. \\
\hline & Detail Development Phase \\
\hline DD1 & Development of drawings and documents. \\
\hline DD2 & Design review. \\
\hline DD3 & Update of construction cost and schedules estimates. \\
\hline & Construction Documentation Phase \\
\hline CD1 & Constructability analysis \\
\hline CD2 & Development of drawings and documents. \\
\hline CD3 & Update of construction cost and schedules estimates. \\
\hline CD4 & Design review \\
\hline & Construction \\
\hline C1 & Coordination of work with trades \\
\hline C2 & Establishment of on-site organization and lines of authority \\
\hline C3 & Development and management of RFIs \\
\hline C4 & Purchase ordering \\
\hline C5 & Contract administration-record keeping \\
\hline C6 & Progress reporting and forecasting \\
\hline
\end{tabular}

For each function three levels of ICT have been developed. Following Tables 5.17- 5.21 define the ICT levels of the functions that are performed at each phase of a project. 
Table 5.17 ICT Levels for Programming Phase Functions

\begin{tabular}{|c|c|c|c|c|}
\hline Functions & Symbol & Level I & Level II & Level III \\
\hline $\begin{array}{l}\text { Development } \\
\text { and selection } \\
\text { of } \\
\text { preliminary } \\
\text { project } \\
\text { concept. }\end{array}$ & $\mathrm{P} 1$ & $\begin{array}{l}\text { - Preliminary concept alternatives are } \\
\text { created, described and analyzed } \\
\text { manually. } \\
\text { - Analysis is not linked to the data } \\
\text { sources. } \\
\text { - Alternatives are qualitatively } \\
\text { assessed and selected. }\end{array}$ & $\begin{array}{l}- \text { Software tools assist the } \\
\text { development of preliminary } \\
\text { concept scenarios. } \\
\text { - Alternates are assessed using } \\
\text { decision support tools to select } \\
\text { the optimal preliminary } \\
\text { concept. }\end{array}$ & $\begin{array}{l}\text { - Preliminary concepts are } \\
\text { automatically generated by } \\
\text { modeling the basic project driver } \\
\text { variables. } \\
\text { - Assessment of the preliminary } \\
\text { concept alternatives is highly } \\
\text { automated. }\end{array}$ \\
\hline $\begin{array}{l}\text { Development } \\
\text { of } \\
\text { preliminary } \\
\text { cost. }\end{array}$ & $\mathrm{P} 2$ & $\begin{array}{l}\text { - Cost estimating is performed with } \\
\text { spreadsheet based tools. } \\
\text { - Most of the information/data is } \\
\text { manually input. }\end{array}$ & $\begin{array}{l}\text { - Cost estimating is linked with } \\
\text { relevant cost index systems and } \\
\text { historical statistical cost } \\
\text { parametric. }\end{array}$ & $\begin{array}{l}\text { - Cost estimating is linked with risk } \\
\text { event impact assessment, and What- } \\
\text { if scenario cost impact analyses can } \\
\text { be conducted fast and simply. } \\
\text { - Material take-offs are automatic. }\end{array}$ \\
\hline $\begin{array}{l}\text { Development } \\
\text { of } \\
\text { preliminary } \\
\text { Schedule }\end{array}$ & P3 & $\begin{array}{l}\text { - Standalone scheduling software } \\
\text { work in isolation from input data } \\
\text { sources. } \\
\text { - No link with historical performance } \\
\text { data or succeeding planning } \\
\text { procedures. }\end{array}$ & $\begin{array}{l}\text { - Automated materials take-off } \\
\text { is linked with scheduling tools. } \\
\text { - Scheduling tools are linked } \\
\text { with database of historical } \\
\text { production rates. }\end{array}$ & $\begin{array}{l}\text { - Scheduling is connected to risk } \\
\text { event impact assessment. } \\
\text { - What-if scenario cost impact } \\
\text { analyses can be conducted fast and } \\
\text { easy. } \\
\text { - Schedule durations are partially } \\
\text { determined by sophisticated } \\
\text { calculations of quantities. } \\
\text { - Scheduling tools are readily linked } \\
\text { with database of historical } \\
\text { production rates. }\end{array}$ \\
\hline
\end{tabular}


Table 5.18 ICT Levels for Schematic Design Phase Functions.

\begin{tabular}{|c|c|c|c|c|}
\hline Functions & Symbol & Level I & Level II & Level III \\
\hline $\begin{array}{l}\text { Development } \\
\text { of } \\
\text { drawings and } \\
\text { documents }\end{array}$ & SD1 & $\begin{array}{l}\text { - Drawings are typically manual or } \\
\text { 2D CAD. } \\
\text { - Document version control is } \\
\text { effortful and intensive. } \\
\text { - Drawings are shared as hardcopy } \\
\text { or/and portable document format } \\
\text { only. }\end{array}$ & $\begin{array}{l}\text { - Drawings are mostly 3D CAD. } \\
\text { - Drawings are shared electronically } \\
\text { such as AutoCAD files. }\end{array}$ & $\begin{array}{l}\text { - BIM models with automated } \\
\text { scope control and change } \\
\text { management tracking. } \\
\text { - Design is shared through BIM } \\
\text { environment. }\end{array}$ \\
\hline $\begin{array}{l}\text { Development } \\
\text { of } \\
\text { Specifications }\end{array}$ & SD2 & $\begin{array}{l}\text { - Specifications are isolated } \\
\text { electronic documents without any } \\
\text { linkages to source documents or } \\
\text { design drawings. }\end{array}$ & $\begin{array}{l}\text { - Specifications are electronic } \\
\text { documents with linkages to source } \\
\text { documents or design drawings. }\end{array}$ & $\begin{array}{l}\text { - Specifications are part of BIM } \\
\text { model and are fully linked to } \\
\text { with project functions such as } \\
\text { building codes, cost estimating, } \\
\text { and project schedule etc. } \\
\text { - Specifications are } \\
\text { automatically updated with any } \\
\text { changes in the principal units. }\end{array}$ \\
\hline $\begin{array}{l}\text { Development } \\
\text { of cost } \\
\text { estimates and } \\
\text { schedules. }\end{array}$ & SD3 & $\begin{array}{l}\text { - Cost and schedule estimating is } \\
\text { performed with standalone } \\
\text { spreadsheet based tools. } \\
\text { - Most of the information/data is } \\
\text { manually input. }\end{array}$ & $\begin{array}{l}\text { - Cost estimating and scheduling is } \\
\text { linked with CAD-driven quantities. } \\
\text { - Estimates changes are } \\
\text { automatically updated and shared }\end{array}$ & $\begin{array}{l}\text { - BIM software has built-in cost } \\
\text { and schedule estimating } \\
\text { features. Material quantities are } \\
\text { automatically extracted through } \\
\text { the model. } \\
\text { - Estimates automatically } \\
\text { evolve as details are refined for } \\
\text { the project. }\end{array}$ \\
\hline $\begin{array}{l}\text { Design } \\
\text { Review }\end{array}$ & SD4 & $\begin{array}{l}\text { - Review of design is manually } \\
\text { done based on 2D document. } \\
\text { - Review commentary is } \\
\text { communicated in forms of } \\
\text { separate notes with no links to the } \\
\text { design. }\end{array}$ & $\begin{array}{l}\text { - Some stand-alone tools are } \\
\text { available to assist design review. The } \\
\text { process is still segregated without } \\
\text { links between the various disciplines. }\end{array}$ & $\begin{array}{l}\text { - Different design options and } \\
\text { alternatives are easily model } \\
\text { and modified in real-time } \\
\text { during design review by end } \\
\text { users or owner }\end{array}$ \\
\hline
\end{tabular}


Table 5.19 ICT Levels for Design Development Phase Functions

\begin{tabular}{|c|c|c|c|c|}
\hline Functions & Symbol & Level I & Level II & Level III \\
\hline $\begin{array}{l}\text { Design and } \\
\text { document } \\
\text { development } \\
\text { for } \\
\text { architectural, } \\
\text { structural, } \\
\text { MEP, FP } \\
\text { systems and } \\
\text { material (A/E) }\end{array}$ & DD1 & $\begin{array}{l}\text { - Drawings are typically manual or } \\
\text { 2D CAD. } \\
\text { - Document version control is } \\
\text { effortful and intensive. } \\
\text { - Drawings are shared as hardcopy } \\
\text { or/and portable document format } \\
\text { only. }\end{array}$ & $\begin{array}{l}\text { - Drawings are mostly 3D CAD. } \\
\text { - Drawings are shared electronically } \\
\text { such as AutoCAD files. }\end{array}$ & $\begin{array}{l}- \text { BIM models with } \\
\text { automated scope control } \\
\text { and change management } \\
\text { tracking. } \\
\text { - Design is shared through } \\
\text { BIM environment. }\end{array}$ \\
\hline $\begin{array}{l}\text { Review of } \\
\text { design during } \\
\text { development, } \\
\text { constructability } \\
\text { review, } \\
\text { availability of } \\
\text { material and } \\
\text { labor etc. } \\
\end{array}$ & DD2 & $\begin{array}{l}\text { - Review of design intent document } \\
\text { is manually done based on } 2 \mathrm{D} \\
\text { document and review commentary is } \\
\text { communicated in forms of separate } \\
\text { notes with no links to the design. The } \\
\text { process is time consuming and prone } \\
\text { to errors and omissions. }\end{array}$ & $\begin{array}{l}\text { - Some stand alone tools are } \\
\text { available to assist design review. } \\
\text { The process is still segregated } \\
\text { without links between the various } \\
\text { disciplines. }\end{array}$ & $\begin{array}{l}\text { - Different design options } \\
\text { and alternatives are easily } \\
\text { modeled and modified in } \\
\text { real-time during design } \\
\text { review by end users and } \\
\text { other project participants. }\end{array}$ \\
\hline $\begin{array}{l}\text { Update of } \\
\text { project } \\
\text { schedule as } \\
\text { required and } \\
\text { Development } \\
\text { of detail } \\
\text { estimate of } \\
\text { construction } \\
\text { cost }\end{array}$ & DD3 & $\begin{array}{l}\text { - Cost and schedule estimating is } \\
\text { performed with standalone } \\
\text { spreadsheet based tools. } \\
\text { - Most of the information/data is } \\
\text { manually input. }\end{array}$ & $\begin{array}{l}\text { - Cost estimating and scheduling is } \\
\text { linked with CAD-driven quantities. } \\
\text { - Estimates changes are } \\
\text { automatically updated and shared }\end{array}$ & $\begin{array}{l}\text { - BIM software has built-in } \\
\text { cost and schedule } \\
\text { estimating features. } \\
\text { Material quantities are } \\
\text { automatically extracted } \\
\text { through the model. } \\
\text { - Estimates automatically } \\
\text { evolve as details are refined } \\
\text { for the project. }\end{array}$ \\
\hline
\end{tabular}


Table 5.20 ICT Levels for Construction Documentation Phase Functions

\begin{tabular}{|c|c|c|c|c|}
\hline Functions & Symbol & Level I & Level II & Level III \\
\hline $\begin{array}{l}\text { Recommendations } \\
\text { on alternative } \\
\text { solutions } \\
\text { whenever design } \\
\text { details affect } \\
\text { construction } \\
\text { feasibility }\end{array}$ & CD1 & $\begin{array}{l}\text { - What-if analyses on design options } \\
\text { are difficult to conduct. } \\
\text { - Constructability analyses, value } \\
\text { engineering has little to no support } \\
\text { from decision system support system. }\end{array}$ & $\begin{array}{l}\text { - Constructability reviews and } \\
\text { value engineering exercises } \\
\text { are supported by decision } \\
\text { support system that analyses } \\
\text { constructability, construction } \\
\text { of difficult elements, and } \\
\text { completeness of design to } \\
\text { permit construction. }\end{array}$ & $\begin{array}{l}\text { - What-if analysis is permitted by } \\
\text { BIM for analyzing construction } \\
\text { sequencing options and } \\
\text { improvement of cost factors. }\end{array}$ \\
\hline $\begin{array}{l}\text { Design drawings } \\
\text { and Specifications } \\
\text { where all major } \\
\text { building systems } \\
\text { are defined, } \\
\text { including any } \\
\text { furnishings, } \\
\text { fixtures and } \\
\text { equipment within } \\
\text { the scope of the } \\
\text { project. }\end{array}$ & $\mathrm{CD} 2$ & $\begin{array}{l}\text { - Drawings are typically manual or } \\
\text { 2D CAD. } \\
\text { - Document version control is } \\
\text { effortful and intensive. } \\
\text { - Drawings are shared as hardcopy } \\
\text { or/and portable document format } \\
\text { only. } \\
\text { - Specifications are isolated electronic } \\
\text { documents without any linkages to } \\
\text { source documents or design drawings. }\end{array}$ & $\begin{array}{l}\text { - Drawings are mostly 3D } \\
\text { CAD. } \\
\text {-Drawings are shared } \\
\text { electronically such as } \\
\text { AutoCAD files. } \\
\text { - Specifications are electronic } \\
\text { documents with linkages to } \\
\text { source documents or design } \\
\text { drawings. }\end{array}$ & $\begin{array}{l}\text { - BIM models with automated } \\
\text { scope control and change } \\
\text { management tracking. } \\
\text { - Design is shared through BIM } \\
\text { environment. } \\
\text { - Specifications are part of BIM } \\
\text { model and are fully linked to with } \\
\text { project functions such as building } \\
\text { codes, cost estimating, and } \\
\text { project schedule etc. }\end{array}$ \\
\hline $\begin{array}{l}\text { Development of } \\
\text { estimate of } \\
\text { construction cost } \\
\text { and schedules }\end{array}$ & CD3 & $\begin{array}{l}\text { - Cost and schedule estimating is } \\
\text { performed with standalone } \\
\text { spreadsheet based tools. } \\
\text { - Most of the information/data is } \\
\text { manually input. }\end{array}$ & $\begin{array}{l}\text { - Cost estimating and } \\
\text { scheduling is linked with } \\
\text { CAD-driven quantities. } \\
\text { - Updates are automatic with } \\
\text { change in estimating } \\
\text { parameters. }\end{array}$ & $\begin{array}{l}\text { - BIM software has built-in cost } \\
\text { and schedule estimating features. } \\
\text { Material quantities are } \\
\text { automatically extracted through } \\
\text { the model. } \\
\text { - Estimates automatically evolve } \\
\text { as details are refined for the } \\
\text { project. }\end{array}$ \\
\hline Design Reviews & CD4 & $\begin{array}{l}\text { - Review of design Intent document is } \\
\text { manually done based on } 2 \mathrm{D} \\
\text { documents. }\end{array}$ & $\begin{array}{l}\text { - Some stand alone tools are } \\
\text { available to assist design } \\
\text { review to limited extent. }\end{array}$ & $\begin{array}{l}\cdot \text { Design reviews are facilitated } \\
\text { through BIM visualization. }\end{array}$ \\
\hline
\end{tabular}


Table 5.21 ICT Levels for Construction Phase Functions

\begin{tabular}{|c|c|c|c|c|}
\hline Functions & Symbol & Level I & Level II & Level III \\
\hline $\begin{array}{l}\text { Coordination } \\
\text { of work with } \\
\text { trades }\end{array}$ & $\mathrm{C} 1$ & $\begin{array}{l}\text { - Design coordination between } \\
\text { several trades is performed } \\
\text { manually by using light table to } \\
\text { determine any conflicts. }\end{array}$ & $\begin{array}{l}\text { - Design coordination is done through } \\
\text { 2D CAD where layers can be easily } \\
\text { turned on and off, simulating a speedy } \\
\text { overlay of tracing paper sheets over } \\
\text { the light table. }\end{array}$ & $\begin{array}{l}\text { - Coordinate building project } \\
\text { through a BIM model allows } \\
\text { for clash detection between the } \\
\text { MEP, FP systems and design } \\
\text { elements }\end{array}$ \\
\hline $\begin{array}{l}\text { Establishment } \\
\text { of on-site } \\
\text { organization } \\
\text { and lines of } \\
\text { authority in } \\
\text { order to } \\
\text { carryout } \\
\text { overall plans } \\
\text { of } \\
\text { construction } \\
\text { team }\end{array}$ & $\mathrm{C} 2$ & $\begin{array}{l}\text { - Project planning meetings } \\
\text { utilize conventional "sticky } \\
\text { note" on whiteboard method. } \\
\text { These plans are then manually } \\
\text { input to scheduling software to } \\
\text { verify logics durations, and } \\
\text { critical path. }\end{array}$ & $\begin{array}{l}\text { - Planning meetings utilize the } \\
\text { electronic projection of the } \\
\text { scheduling software. The schedule is } \\
\text { built simultaneously with the input } \\
\text { from project participants. } \\
\text { - Resource loaded schedules support } \\
\text { cash flow management/ projections. }\end{array}$ & $\begin{array}{l}\text { - Planning meetings utilize the } \\
\text { Smart Boards that allow project } \\
\text { participants to directly draw the } \\
\text { plans. These plans can be } \\
\text { linked into the software to } \\
\text { create the baseline CPM much } \\
\text { faster than conventional } \\
\text { methods. } \\
\text { - Schedules can be quickly } \\
\text { verified through incorporated of } \\
\text { vendor data and supply chain } \\
\text { capacity. }\end{array}$ \\
\hline $\begin{array}{l}\text { Development } \\
\text { and } \\
\text { management } \\
\text { of RFIs }\end{array}$ & C3 & $\begin{array}{l}\text { - Physical copies of RFIs may } \\
\text { be tracked using specialized } \\
\text { software. } \\
\text { - RFI transfer methods are } \\
\text { manual. } \\
\text { - RFI response time is longer } \\
\text { due to the long information flow } \\
\text { chain that restricts direct } \\
\text { response to the concerned } \\
\text { participants. }\end{array}$ & $\begin{array}{l}\text { - RFIs are recorded and tracked } \\
\text { through the PMIS, all concerned } \\
\text { participants usually addressed to RFI } \\
\text { correspondence through email. } \\
\text { - Response time on RFI is improved } \\
\text { due to direct responses. }\end{array}$ & $\begin{array}{l}\text { - The BIM model is used to } \\
\text { capture and share issues as they } \\
\text { are being generated and } \\
\text { supplement, manage or enhance } \\
\text { the RFI process. }\end{array}$ \\
\hline
\end{tabular}


Table 5.21 ICT Levels for Construction Phase Function (Continued).

\begin{tabular}{|c|c|c|c|c|}
\hline Functions & Symbol & Level I & Level II & Level III \\
\hline $\begin{array}{l}\text { Purchase } \\
\text { ordering }\end{array}$ & $\mathrm{C} 4$ & $\begin{array}{l}\text { - Purchase orders are manual } \\
\text { processed; hardcopies of the } \\
\text { orders are transferred. } \\
\text { - Hardcopy invoices } \\
\text { processed by email. }\end{array}$ & $\begin{array}{l}\text { - Purchased orders are mostly done } \\
\text { electronically. E-signs are acceptable. } \\
\text { - Suppliers have access to client } \\
\text { system to update status information. } \\
\text {-Electronic invoices and payment } \\
\text { schedule is managed by supplier per } \\
\text { terms and conditions. }\end{array}$ & $\begin{array}{l}\text { - Invoicing is coordinated } \\
\text { electronically. } \\
\text { - Electronic authorization and } \\
\text { approval history is available for } \\
\text { all information. }\end{array}$ \\
\hline $\begin{array}{l}\text { Contract } \\
\text { Administration- } \\
\text { Record } \\
\text { Keeping }\end{array}$ & $\mathrm{C} 5$ & $\begin{array}{l}\text { - Hardcopies of contract } \\
\text { administration material } \\
\text { (contracts, change orders etc.) } \\
\text { are stored as separate file in } \\
\text { the filing cabinets. } \\
\text { - Written records of } \\
\text { conversations usually are } \\
\text { distributed to confirm } \\
\text { understandings reached } \\
\text { verbally. } \\
\text { - Auditing exercise of } \\
\text { hardcopies of records is time } \\
\text { and labor intensive. }\end{array}$ & $\begin{array}{l}\text { - Record keeping is a combination of } \\
\text { hardcopies and electronic documents. } \\
\text { - Signed hardcopies of documents such } \\
\text { as contract agreement and change } \\
\text { orders are maintained while other } \\
\text { communications such as RFI, minutes } \\
\text { of meetings etc are maintained } \\
\text { electronically. }\end{array}$ & $\begin{array}{l}\text { - PMIS allows participants to } \\
\text { communicate with each other, } \\
\text { deliver contractual notices, } \\
\text { amendments, alter project } \\
\text { drawings and provide project } \\
\text { approvals. } \\
\text { - Central filing system provides } \\
\text { storage, retrieval and distribution } \\
\text { of project documentation and } \\
\text { drawings. } \\
\text { - Electronic forms of financial } \\
\text { records are maintained in central } \\
\text { PMIS. }\end{array}$ \\
\hline $\begin{array}{l}\text { Recording the } \\
\text { project } \\
\text { progress, } \\
\text { preparing } \\
\text { monthly } \\
\text { progress } \\
\text { reports, } \\
\text { progress } \\
\text { forecasting. }\end{array}$ & C6 & $\begin{array}{l}\text { - Progress monitoring and } \\
\text { tracking for several vital signs } \\
\text { of the project is performed } \\
\text { through individual systems. } \\
\text { - Progress report documents } \\
\text { present limited views of } \\
\text { project status. } \\
\text { Forecasting reports are } \\
\text { manually generated based on } \\
\text { progress reports. }\end{array}$ & $\begin{array}{l}\text { - Limited linkages of electronic } \\
\text { documents with BIM models. } \\
\text { - Multiple views of project status can } \\
\text { be extracted and reported. } \\
\text { - Forecasting is facilitated by BIM } \\
\text { models integrated with schedules (4D). }\end{array}$ & $\begin{array}{l}\text { - Use of sensing technology } \\
\text { allows for automatic progress } \\
\text { monitoring and update. } \\
\text { - On demand multiple view } \\
\text { reporting is possible. } \\
\text { - A schedule tied to the model to } \\
\text { allow visualization of deviations } \\
\text { of as-built from as-planned } \\
\text { sequences and dVurations. }\end{array}$ \\
\hline
\end{tabular}




\subsection{RELATIONSHIP BETWEEN IPD PRINCIPLES AND PROJECT FUNCTIONS}

Since the ICT push and IPD pull classifications are already established in the above sections, the relationship is identified between the project functions and ICT push principles. These relationships are logically derived based on the nature of function and IPD principles. For example, one of the IPD principles, JDPTC requires that the project participants collaborate early in the project to define and validate the project target criteria. This principle is directly associated with the programming phase function namely; development and selection of preliminary project concept, which is basically performed to analyze the needs and requirements of the facility and to determine that needs and requirements matches the available project budget and/ or time constraints.

Following Table 5.22 indicates the relationship between IPD principles and project functions at each phase based on the same logic. It should be noted that the same function may be associated with more than one IPD principles. For example while the project function of project progress reporting, progress forecasting is associated with CDM, it is also closely related to WTC and OC.

The purpose of identifying relationship between IPD principles and projection functions is to connect ICT push IPD principles and levels of ICT. Each function can be performed using either Level I, II or III ICT tools and methods as described in detail in the above section. In addition, each function by the nature of the task it defines can potentially affect several IPD principles. The predominant effect of project function on ICT push principle is considered and the relations are shown in the following Table 5.22. 
Table 5.22 IPD Principles and Project Functions

\begin{tabular}{|c|c|c|c|c|c|c|c|}
\hline Functions & Symbol & CDM & FT & JDPTC & ID & WTC & $\mathbf{O C}$ \\
\hline \multicolumn{8}{|l|}{ Programming } \\
\hline $\begin{array}{l}\text { Development and selection of } \\
\text { preliminary project concept. }\end{array}$ & $\mathrm{P} 1$ & & & $\checkmark$ & & & \\
\hline Development of preliminary cost. & $\mathrm{P} 2$ & & & $\checkmark$ & & & \\
\hline Development of preliminary schedule & $\mathrm{P} 3$ & & & $\checkmark$ & & & \\
\hline \multicolumn{8}{|l|}{ Schematic Design } \\
\hline $\begin{array}{l}\text { Development of drawings and } \\
\text { documents }\end{array}$ & SD1 & & & $\checkmark$ & $\checkmark$ & $\checkmark$ & $\checkmark$ \\
\hline Development of specifications & $\mathrm{SD} 2$ & & & $\checkmark$ & $\checkmark$ & & \\
\hline $\begin{array}{l}\text { Development of cost estimates and } \\
\text { schedules. }\end{array}$ & SD3 & & & $\checkmark$ & & & \\
\hline Design reviews & SD4 & $\checkmark$ & & & $\checkmark$ & & \\
\hline \multicolumn{8}{|l|}{ Detail Development Phase } \\
\hline $\begin{array}{l}\text { Development of drawings and } \\
\text { documents }\end{array}$ & DD1 & & & & $\checkmark$ & $\checkmark$ & $\checkmark$ \\
\hline Design reviews & DD2 & $\checkmark$ & & & $\checkmark$ & & \\
\hline $\begin{array}{l}\text { Update of project schedule and } \\
\text { development of detail estimate of } \\
\text { construction cost }\end{array}$ & DD3 & $\checkmark$ & & & & $\checkmark$ & $\checkmark$ \\
\hline \multicolumn{8}{|l|}{ Construction Documentation Phase } \\
\hline $\begin{array}{l}\text { Recommendations on alternative } \\
\text { solutions whenever design details } \\
\text { affect construction feasibility }\end{array}$ & $\mathrm{CD} 1$ & & & & $\checkmark$ & $\checkmark$ & $\checkmark$ \\
\hline $\begin{array}{l}\text { Design drawings and Specifications } \\
\text { where all major building systems are } \\
\text { defined, including any furnishings, } \\
\text { fixtures and equipment within the } \\
\text { scope of the project. }\end{array}$ & $\mathrm{CD} 2$ & & & & $\checkmark$ & & \\
\hline $\begin{array}{l}\text { Development of estimate of } \\
\text { construction cost and schedules }\end{array}$ & CD3 & $\checkmark$ & & & & $\checkmark$ & $\checkmark$ \\
\hline Design Reviews & $\mathrm{CD} 4$ & $\checkmark$ & & & $\checkmark$ & & \\
\hline \multicolumn{8}{|l|}{ Construction } \\
\hline Coordination of work with trades & $\mathrm{C} 1$ & $\checkmark$ & & & & $\checkmark$ & $\checkmark$ \\
\hline $\begin{array}{l}\text { Establishment of on-site organization } \\
\text { and lines of authority }\end{array}$ & $\mathrm{C} 2$ & $\checkmark$ & & & & $\checkmark$ & $\checkmark$ \\
\hline $\begin{array}{l}\text { Development and management of } \\
\text { RFIs }\end{array}$ & $\mathrm{C} 3$ & $\checkmark$ & & & & $\checkmark$ & $\checkmark$ \\
\hline Purchase ordering & $\mathrm{C} 4$ & & $\checkmark$ & & & & \\
\hline $\begin{array}{l}\text { Contract Administration-Record } \\
\text { Keeping }\end{array}$ & $\mathrm{C} 5$ & & $\checkmark$ & & & $\checkmark$ & $\checkmark$ \\
\hline $\begin{array}{l}\text { Progress reporting, progress } \\
\text { forecasting }\end{array}$ & C6 & $\checkmark$ & & & & $\checkmark$ & $\checkmark$ \\
\hline
\end{tabular}


Development of various components of IPD-RAM and the output of each component were discussed in sections 5.2 through 5.4. The following section briefly describes how these components are utilized to present the final output of the model.

\subsection{APPLICATION OF IPD-RAM}

The above sections explained the development of measuring mechanism of IPD principles' readiness scores and evaluation mechanism for ICT Levels. This section will briefly describe the application of the model to demonstrate how these assessments will be reported and what the significance of each reported item is. For this, a hypothetical case $\alpha$ was developed. The assumptions of this hypothetical example are explained below.

\subsubsection{HYPOTHETICAL CASE $\alpha$ DESCRIPTION}

Following are the assumptions made for defining project characteristics.

- The owner is the facilities management department of a public university in Florida, who is willing to bring changes in project delivery method but is restricted in authority to implement IPD as a delivery method. Owner has exercised various informational and organizational steps to become closer to IPD.

- The project is delivered through CM at Risk delivery method.

- $\mathrm{A} / \mathrm{E}$ and $\mathrm{CM} / \mathrm{GC}$ were brought early on to the project during the programming stage. 
- The owner had pre-defined budget for constructing the facility. Both $\mathrm{A} / \mathrm{E}$ and $\mathrm{CM} / \mathrm{GC}$ were involved in validation of target cost of the facility.

- Major subcontractors were involved in the process of developing guaranteed maximum price for $\mathrm{CM} / \mathrm{GC}$.

- Both $\mathrm{A} / \mathrm{E}$ and $\mathrm{CM}$ had predefined incentives for cost saving on the project.

- $\mathrm{A} / \mathrm{E}$ and $\mathrm{CM}$ had past working experience with each other. Owner had work experience with the $\mathrm{A} / \mathrm{E}$ and $\mathrm{CM}$ on different past projects.

- Weekly project meetings were conducted during the design and construction phases and additional workshops and meetings were conducted throughout the project to increase collaboration and trust.

- Although BIM was not contractually required, based on the experience, the team decided to use BIM for design and construction of the facility.

- Open books were maintained by $\mathrm{A} / \mathrm{E}$ and its consultants and $\mathrm{CM} / \mathrm{GC}$ and its subs. All books were open for owners, $\mathrm{CM}$ and $\mathrm{A} / \mathrm{Es}$

\subsubsection{IPD READINESS SCORE}

Based on the above assumptions the IPD score of the case project is assessed. The results of assessment are shown in Table 5.23. Each row describes the assessed score for each of the ten selected IPD principles, the aggregate score is also determined at the bottom. The aggregate score does not tell much about the project in isolation as 52.5 is almost $50 \%$ score but does not represent that all IPD principles were performed at scale point 5. However, the aggregate can be useful for comparing two or more projects conducted by the same organization to determine the readiness gaps based on differences 
in the delivery of the compared projects. It is important to compare several cases from the organization that were performed differently for example by different project team arrangements or different delivery methods to be able to access the true readiness of the organization.

Table 5.23 IPD Readiness Score of Hypothetical Case $\alpha$

\begin{tabular}{|c|c|c|}
\hline Principle & Score & Remarks \\
\hline EIKP & 7.5 & $\begin{array}{l}\text { Three major participants are involved at programming phase however } \\
7.5 \text { is assigned to adjust the score for relatively late inclusion of } \\
\text { subcontractors }\end{array}$ \\
\hline CDM & 5 & $\begin{array}{l}\text { As input is taken from Owners, } \mathrm{A} / \mathrm{E} \text {, and Contractor and same } \\
\text { participants were involved in decision-making. }\end{array}$ \\
\hline ID & 7.5 & $\begin{array}{l}\text { As A/E, contractors, and owners were involved in design from the SD } \\
\text { phase (subs at CD phase) and met regularly. }\end{array}$ \\
\hline JDPTC & 5 & $\begin{array}{l}\text { When input is taken from Owners, } \mathrm{A} / \mathrm{E} \text {, and Contractor while project } \\
\text { target criteria are devised by only Owners and/or A/E. }\end{array}$ \\
\hline FT & 5 & $\begin{array}{l}\text { Open books are maintained by all project participants excluding owners } \\
\text { and Owner, A/E and Contractor have access to records. }\end{array}$ \\
\hline SRR & 2.5 & As both A/E and CM had predefined incentives for cost saving only \\
\hline LWKP & $\mathbf{0}$ & No specific limit on liability or "no-sue" clause in the contracts. \\
\hline MRT & 7.5 & $\begin{array}{l}\text { Trust-building workshops were conducted during the project phases, } \\
\text { team has high prior working experience and trust competence was not } \\
\text { considered as selection criteria. }\end{array}$ \\
\hline WTC & 7.5 & $\begin{array}{l}\text { Goals are aligned but interaction between the participants is partially } \\
\text { open }\end{array}$ \\
\hline OC & 5 & $\begin{array}{l}\text { Communication flow is informally open and frequency of meetings is } \\
\text { high. }\end{array}$ \\
\hline Aggregate & 52.5 & \\
\hline
\end{tabular}

\subsubsection{DETERMINATION OF ICT LEVEL}

The level of ICT is determined using ICT level tables for each project phase as defined in section 5.5. The next step is to identify the level of ICT and specific ICT tools and methods utilized to perform each project function and map them with associated ICT push principles. As an example, Table 5.24 shows the level of ICT tools and methods 
utilized for all functions that are associated with the IPD principle of JDPTC. It can be observed that the level of ICT use can vary with function within the phase as well.

Table 5.24 ICT level of Hypothetical Case $\alpha$

\begin{tabular}{|c|c|l|}
\hline Functions & $\begin{array}{c}\text { ICT } \\
\text { Level }\end{array}$ & JDPTC (5) \\
\hline P1 & I & Spreadsheet base tools with manual inputs \\
\hline P2 & II & $\begin{array}{l}\text { Cost estimating linked with cost index systems and historical statistical } \\
\text { cost parametric }\end{array}$ \\
\hline P3 & II & Scheduling tools linked with database of historical production rates \\
\hline SD1 & III & 3D Revit model utilized for design drafting \\
\hline SD2 & I & Specifications without links to source data or design \\
\hline SD3 & II & Cost estimating and scheduling linked with CAD-driven quantities \\
\hline SD4 & III & $\begin{array}{l}\text { Design options and alternatives modeled and modified in real-time during } \\
\text { design reviews }\end{array}$ \\
\hline
\end{tabular}

The ICT levels for all the project functions are determined similarly. Once this exercise is done, the next step is to identify gaps in IPD readiness and ICT levels. As discussed earlier for this step several projects need to be compared. This process is explained in detail in chapter 7 , the section below briefly explains the significance of the assessed IPD readiness score and ICT levels for an individual project.

\subsection{GAP IDENTIFICATION}

Once the IPD readiness score and ICT levels are assessed, these can be utilized for gap identification. The results of these two assessments can be mapped in a tabular form. Example of this representation is presented in Table 5.25. Each Cell of this table presents a snapshot of project and can act as a unit of analysis for gap identification. 
Table 5.25 IPD Readiness Report of Hypothetical Case $\alpha$

\begin{tabular}{|l|c|c|c|c|c|c|}
\hline & $\mathrm{CDM}=5$ & JDPTC $=5$ & $\mathrm{ID}=7.5$ & $\mathrm{OC}=5$ & $\mathrm{WTC}=5$ & $\mathrm{FT}=5$ \\
\hline PI & & I & & & I & \\
\hline P2 & & II & & & & \\
\hline P3 & & II & & & & \\
\hline SD1 & & III & III & & & \\
\hline SD2 & & I & I & & & \\
\hline SD3 & II & II & & & & \\
\hline SD4 & III & III & III & & & \\
\hline DD1 & & & III & III & III & \\
\hline DD2 & III & & III & III & & \\
\hline DD3 & I & & I & I & I & \\
\hline CD1 & III & & III & III & III & \\
\hline CD2 & & & III & & & \\
\hline CD3 & & & I & & & \\
\hline CD4 & I & & & I & I & \\
\hline C1 & III & & & III & III & \\
\hline C2 & II & & & II & II & \\
\hline C3 & II & & & II & II & \\
\hline C4 & & & & & & I \\
\hline C5 & I & & & & I & I \\
\hline C6 & II & & & II & II & \\
\hline
\end{tabular}

As mentioned above, gap identification is more meaningful when several case projects from the same organization are analyzed to highlight gaps in organization's IPD readiness. This is further discussed in chapter 7 where multiple cases from an owner organization are compared for more detailed gap analysis.

\subsection{VALIDATION OF MODEL}

In order to validate the model, the researcher received feedback from field experts on measuring processes of the IPD-RAM and its ability to measure IPD- readiness of public owner organizations. Interviews were conducted to solicit expert judgment on the developed model. The detailed methodology for expert feedback is discussed in chapter 3. In this section the major findings from the feedback are discussed. Following table 
describes the profiles of the experts that were involved in the validation process. The current designation, overall experience and related areas of expertise are shown in Table 5.26. (Their names and designations are not published).

Table 5.26 Experts Profiles

\begin{tabular}{|l|l|l|l|}
\hline Expert & Designation & Experience & Area of Expertise \\
\hline 1 & $\begin{array}{l}\text { Managing Director - } \\
\text { Planning }\end{array}$ & $\begin{array}{l}\text { Planning, design, construction and project } \\
\text { management for large, public funded capital } \\
\text { projects. }\end{array}$ \\
\hline 2 & $\begin{array}{l}\text { Senior Coach- Lean } \\
\text { Project Consulting }\end{array}$ & 30 years & $\begin{array}{l}\text { Integrated project delivery and lean } \\
\text { construction, }\end{array}$ \\
\hline 3 & $\begin{array}{l}\text { Partner } \\
\text { (Construction group) }\end{array}$ & 30 years & $\begin{array}{l}\text { Construction law. } \\
\text { Project management and engineering. }\end{array}$ \\
\hline 4 & Sr. Project Manage & 25 years & $\begin{array}{l}\text { Lean-IPD, VDC-BIM Applications- } \\
\text { Integrations }\end{array}$ \\
\hline 5 & Consultant & 30 year & $\begin{array}{l}\text { Integrated project delivery, interoperable } \\
\text { software systems and long-term management } \\
\text { of information systems. } \\
\text { Planning and management of public and } \\
\text { private facilities. }\end{array}$ \\
\hline
\end{tabular}

The model was presented to experts before the interview. At the beginning of each of the interviews, the goals and objectives of the research were explained to the experts. Next, to determine the experts understanding of the concept, the . Following discussion will briefly summarize the results of this exercise.

\subsubsection{EXPERTS' FEEDBACK}

There was consensus among the experts on the fact that generally there are limitations on public owners to enter into an IPD contract. According to one expert, " the majority public organizations at present do not have ability to enter into IPD Agreements. The major hindrances were identified as the unavailability of IPD related of insurance, 
inability to waive liabilities on public project and the vagueness of risk sharing mechanism.

For those public agencies, that do have the authority to implement alternative project delivery methods, design- build with bridging document was regarded as the most suitable option among the available alternative delivery methods to achieve some of the aspects of IPD. According to one of the experts, "public owners with design build authority can benefit from the collaborative process through early involvement of key participants and the use of tools such as BIM"

When asked about the probable use of $\mathrm{CM}$ at Risk for the purpose, the experts identified that although it allows the early involvement of contractor, the limitations of the method is the guaranteed maximum price (GMP) that contractor has to provide to owner. GMP takes away the risk cost overruns from the owner and make contractor liable for it. Experts identified that there can be set target within the GMP where owners and contractors can share the incentives of completing within the target cost. However it is not true "pain and gain" sharing.

Overall, there was consensus among the experts that the effectiveness of the ICT tools to facilitate IPD readiness increases with higher-level use of ICT. Level I tools were found to least effective in increasing the IPD readiness mostly the tools at this level were regarded as tools assisting the function operations which may result in increasing the efficiency of operation but are not influencing the effectiveness of the operation. The higher Level tools at Level II and three are on the other hand increasing the effectiveness 
of the function by providing linkages and integration between several operations of the function and increasing the interoperability of information.

The use of BIM was highly appreciated as a facilitator to the IPD or collaborative delivery process. One of the experts explained there is a misconception in the industry and a section of industry regards BIM use IPD. He further elaborated that implementing $\mathrm{BIM}$ on the project does not automatically assures that the project will be collaborative however; the process can be "helped" by the use of BIM. Another expert shared the success story where fully loaded BIM model was employed under collaborative designbuild type of arrangement on a federal project.

When specifically asked about the joint development of project target criteria, one of the experts explained that although the owner organization and users defines the needs of the facility, availability of budget and time requirements during the programming phase of the project. The early validation of the targets by the design and construction professionals is important. This validation leads to target value design, he explained, which is design the facility within target cost rather than conventional method where design defines the cost of the project. Another expert elaborated on the importance of jointly developed target criteria by explaining, "Since $80 \%$ of the cost decisions are made during the first $20 \%$ of the design, collaboration between the contractors and the designers [early in design phase] is the biggest source of potential savings". This highlights the importance of informational and organizational integration. The experts agreed to the benefits of advance ICT tools like tools that allow links with historical cost indices and performance indices in setting cost, schedules targets, and highlighted the 
importance of availability of libraries of cost for the different building types. However, at the same time cautioned that these tools should only be used as" guides" while setting the targets and other important parameters like current market variations should also be considered. This again affirms the importance of early contractor involvement.

The use of several tools of BIM during the design phase for authoring, analyzing, reviewing and sharing the design by project participants was affirmed to be highly effective for evaluating effectiveness of design in meeting building program criteria and owner's needs and better control and quality control of design, cost and schedule.

On the questions related to collaborative decision making, the experts emphasized on devising appropriate decision making teams that allows the participants to make an jointly own the decisions. Layered and decentralized decision making structure with involvement of all key participants, clear reporting lines with defined roles and responsibilities for coordinating aspects of the design and construction processes were regarded essentials to collaborative decision making.

Fiscal transparency was regarded very important in establishing the trust between the project participants and all experts had consensus over the probable use of central project management information system to increase the fiscal transparency.

On the questions related to open communication and willingness to communicate, the experts identified the importance of co-location and "Big Room" concept in developing the suitable environment to instill open communication and collaboration . One of the expert with vast experience of working on the public projects shared his 
experience where the presence of the whole team under one big room without any walls and barriers between the project team allowed the team to achieve to work on the project without even a single RFI. In situations where co-location is not possible the importance of the use of project management systems was identified to be beneficial.

Above discussion summarizes the main points of the expert interviews. These interviews served three purposes, (1) validation of ICT level definitions, (2) validation of push effect of ICT tools on IPD readiness, (3) support in definition of improvement strategies.

\subsection{CHAPTER SUMMARY}

The development and features of IPD-RAM are discussed in this chapter. A systematic detail of each of the components of IPD-RAM is included. Furthermore, the outcomes of the model as a part of the IPD readiness report is presented and explained. The process used for gap identification is presented with the help of a hypothetical case study. The next chapter will present implementation of the framework using real FIU case studies. 


\section{CHAPTER-6: APPLICATION OF IPD-RAM}

\subsection{INTRODUCTION}

Development of IPD-RAM is discussed in the previous chapter. This chapter will focus on the application of the model to real world projects from a public owner organization. In this chapter, a brief overview of the selected owner organization is provided followed by the application of the model on selected case projects.

\subsection{STUDY ORGANIZATION}

For this research, Facilities Management Department of Florida International University has been selected as a study organization. The reasons for selecting this particular organization were that (1) it satisfies the criteria of being a public construction owner organization (2) it has an array of projects available ranging from 10 to 15 years old projects to recently finished projects, and (3) the researcher's ease of access to the organization and project case records. A brief overview of the organization is given in the following.

\subsubsection{ORGANIZATION PROFILE}

Facilities Management Department of FIU has eight sections that provide overall assistance to all facilities that are present in the three campuses of the University. Figure 6.1 present the organization chart of facilities management department. For this study, construction services section has been focused. This section oversees the complete administration of projects in the capital construction program of the University. The 
section is responsible for the supervision of architectural and engineering consultants as well as construction companies retained for the implementation of new construction and refurbishment projects. Typical projects include design, construction, demolition, remodeling, and renovation of a variety of buildings as well as site improvements and infrastructure.

\subsubsection{DATA COLLECTION}

For this research, six projects were selected and data was collected for each project. To account for the influence of time period on project delivery and use of ICT, the projects were two projects were selected that were 8-10 years old completions, three projects were recently finished facilities (1-2 years old) and one project that was still in construction phase at the time of this report was also studied. The selected projects are represented in Table 6.1.

Table 6.1: List of Selected Case-Study Projects

\begin{tabular}{|c|c|c|c|c|c|}
\hline Project Name & Designation & Start Date & $\begin{array}{l}\text { Finish } \\
\text { Date }\end{array}$ & $\begin{array}{l}\text { Amount } \\
\text { (\$ millions) }\end{array}$ & $\begin{array}{l}\text { Area } \\
\text { (sq.-ft.) }\end{array}$ \\
\hline Academic Health Center 4 & Case A & August 2011 & $\begin{array}{l}\text { February } \\
2013\end{array}$ & $\$ 40.5$ & 137,000 \\
\hline $\begin{array}{l}\text { School of International } \\
\text { and Public Affairs }\end{array}$ & Case B & July 2009 & $\begin{array}{l}\text { January } \\
2011\end{array}$ & $\$ 19.3$ & 58,238 \\
\hline Marine Biology Building & Case $\mathrm{C}$ & June 2004 & June 2006 & $\$ 10.6$ & 48,000 \\
\hline Parkview Housing Project & Case D & May 2012 & July 2013 & $\$ 39.8$ & 217,099 \\
\hline Frost Art Museum & Case E & August 2004 & May 2007 & $\$ 15.1$ & 46,000 \\
\hline $\begin{array}{l}\text { Mixed Use College of } \\
\text { Business Building }\end{array}$ & Case $\mathrm{F}$ & July 2013 & $\begin{array}{l}\text { July } 2014 \\
\text { (Expected } \\
\text { Finish) }\end{array}$ & $\$ 27.0$ & 106,611 \\
\hline
\end{tabular}


For each of the projects, the project information was collected through several means. First source of data was project files for each project that are maintained by the study organization. FIU maintains 54 separate files for each project starting from preprogram correspondence to contract completion certificates and inspection reports. For this study, following files were studied namely; A/E contracts, construction contracts, schematic design correspondence, design development correspondence and approval, construction documentation and approval, bid correspondence, GMP contract, preconstruction file, construction change orders, preconstruction conference report, monthly progress reports by $\mathrm{A} / \mathrm{E}$, minutes of periodic construction conferences and request for information (RFI). All these files are hardcopies of the project information that are filed in several filling cabinets.

Secondly, information was collected through interviews of project managers and representatives of FIU's, A/E and contractors. For records like RFIs logs, BIM execution plan, the project participants were requested to provide electronic records of the documents. Apart from the formal interview, several telephonic and email communications were also frequently made. Following Table 6.2 indicates the type of information typically collected for each project and its data sources.

It should be noted that all the information collected for the projects was verified from more than one source. Data triangulation approach was adopted to increase the validity of the study. In consistencies between the information between different sources was identified as the opportunity to identify the deeper meaning of data. 


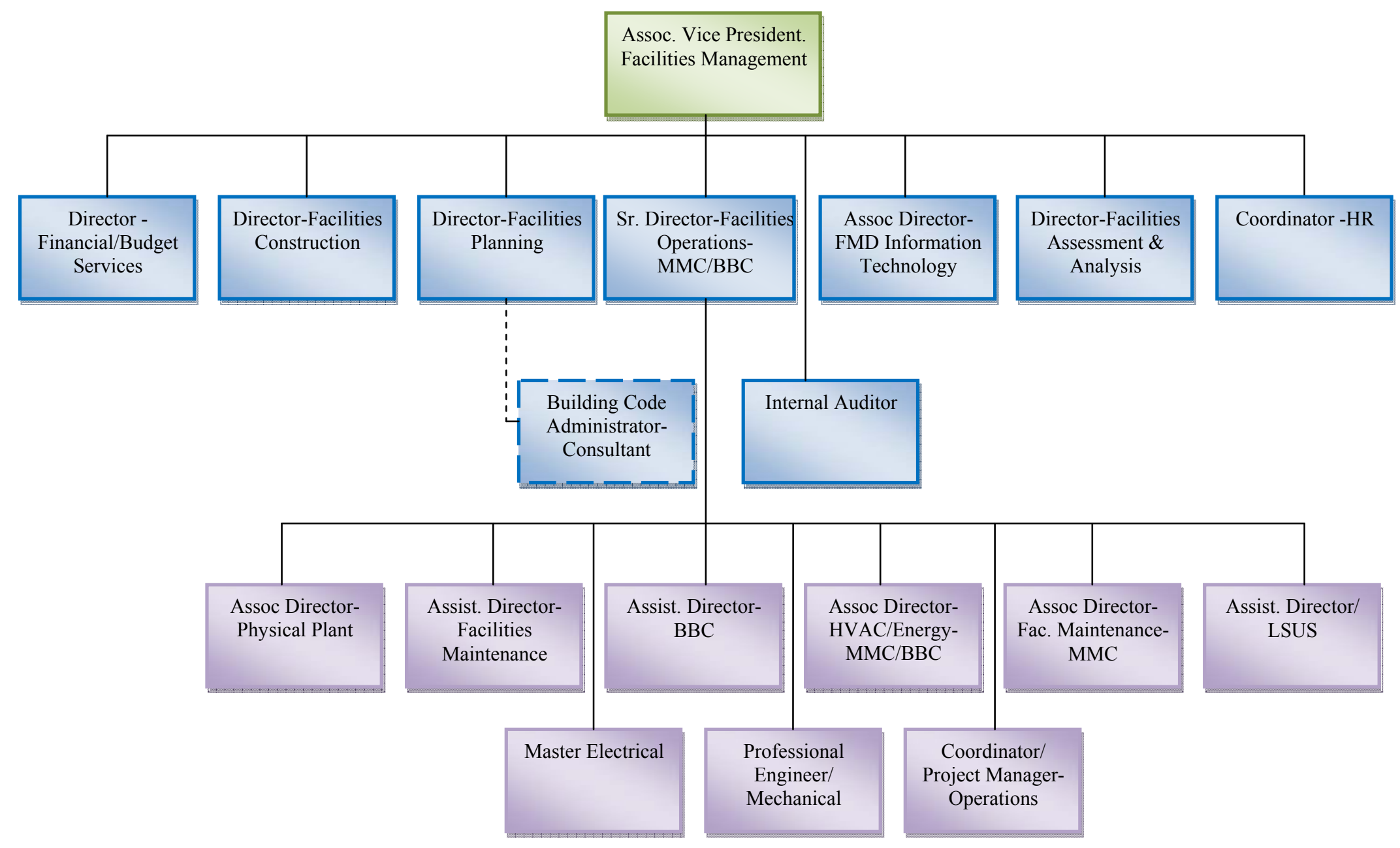

Figure 6.3: Organizational Chart of Facilities Management Department, FIU 
Table 6. 2: Information Collected and Sources of Information

\begin{tabular}{|c|c|}
\hline Information /data & Source \\
\hline 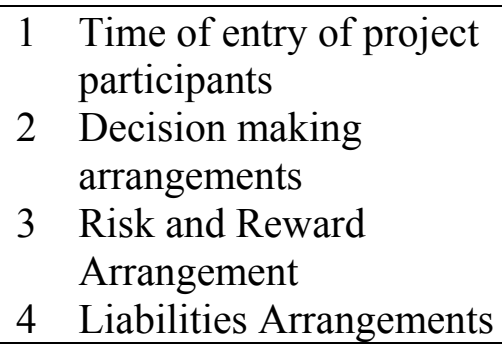 & $\begin{array}{l}\text { - Contract Agreements between owner and A/E. } \\
\text { - Contract Agreements between owner and CM/GC. } \\
\text { - Interviews with project manager (FIU), project } \\
\text { manager (CM/CG). } \\
\text { - Subcontract documents }\end{array}$ \\
\hline 5 Meeting Frequency & $\begin{array}{l}\text { - Project correspondence files for SD,DD,CD and } \\
\text { construction phases } \\
\text { - Minutes of meeting of OAC meetings }\end{array}$ \\
\hline $6 \begin{array}{l}\text { Selection Criteria for } \\
\text { project participants }\end{array}$ & $\begin{array}{l}\text { - Professional Qualifications Supplement for A/E } \\
\text { (PQS) } \\
\text { - Construction Manager Qualifications Supplement } \\
\text { (CMQS) } \\
\text { - Interviews with project manager (FIU), }\end{array}$ \\
\hline 7 Communication Flow & $\begin{array}{l}\text { - General Conditions Document of Contract. } \\
\text { - Minutes of meeting for Pre-Construction meeting } \\
\text { - Minutes of meeting of OAC meetings } \\
\text { - RFI logs } \\
\text { - Interviews with representatives of A/E, project } \\
\text { manager (FIU), project manager (CM/CG). }\end{array}$ \\
\hline 8 Financial Records & $\begin{array}{l}\text { - Contract Agreements between owner and A/E. } \\
\text { - Contract Agreements between owner and CM/GC. } \\
\text { - Payment Invoices } \\
\text { - Change Orders }\end{array}$ \\
\hline $\begin{array}{l}9 \text { Design authoring and } \\
\text { review tools } \\
10 \begin{array}{l}\text { Scheduling and } \\
\text { estimating tools }\end{array}\end{array}$ & $\begin{array}{l}\text { - Project Drawings and documents } \\
\text { - Project correspondence files for SD,DD,CD and } \\
\text { construction phases } \\
\text { - BIM Execution plans (if applicable). } \\
\text { - Interviews with representatives of A/E, project } \\
\text { manager (FIU), project manager (CM/CG). } \\
\text { - Contract Agreements between owner and A/E. }\end{array}$ \\
\hline 11 Communication tools & $\begin{array}{l}\text { - Project correspondence files for SD,DD,CD and } \\
\text { construction phases } \\
\text { - Interviews with representatives of A/E, project } \\
\text { manager (FIU), project manager (CM/CG). }\end{array}$ \\
\hline
\end{tabular}


After presenting a brief overview of the organization and type of data collected, the application of IPD-RAM on selected case projects is demonstrated in the following section.

\subsection{APPLICATION OF IPD-RAM ON CASE PROJECTS}

As explained earlier, six projects were selected for application of IPD-RAM. Following sections will present a brief overview of the project followed by step by step application of IPD RAM. IPD Readiness report for each case is also included.

\subsubsection{CASE A- ACADEMIC HEALTH CENTER 4}

Academic Health Center 4 (AHC-4) is located along the northern edge of Florida International University's Modesto A. Maidique Campus. It is a five floors and a mechanical penthouse 137,000-sq.-ft., institutional laboratory project that followed FIU's vision to become more interdisciplinary and multidisciplinary.

AHC4 provides flexible laboratory space to serve multi-disciplinary research programs including arts and sciences, engineering, informatics, the College of Medicine,

the Robert Stempel School of Public Health, and the College of Nursing and Health Sciences.

This complex and ultramodern structure was designed by Perkins + Will, and constructed by DPR Construction (CM/GC). The project has won awards for design excellence from the American Institute of Architects (AIA) and the Society of American Registered Architects (SARA).

Following is a brief project description. 


\subsubsection{PROJECT DESCRIPTION}

Project Name: Academic Health Center 4 - (BT-876)

Location: FIU Modesto A. Maidique Campus

Building Type: Educational

Owner: Florida International University (FIU)

Architect: Perkins \& Will Architects, Inc., (P\&W)

Contractor: DPR Construction, Inc., (DPR)

Project Delivery Method: CM-at-Risk

Project Start Date: August 8Th 2011

Finish Date: February 4, 2013

Footprint Area: 137,000-sq.-ft.

\subsubsection{DETERMINATION OF IPD READINESS SCORE}

Table 6.3 gives the IPD readiness score for case-A. The subsequent columns provide the source of data and remarks that resulted in deciding the scores for each principle.

The aggregate score for the case came out to be 32.5 . This score is considerably low. One reason for this score is that the project did not practiced SRR and LWKP; the two contractual principles scored zero in each of these principles. If we analyze the score for ICT push principles, this case the aggregate score is 25 out of 60 . If this is compared with the total score of the case, it constitutes the majority of the score 25 out of 32.5 . So it can be said that this particular can be influenced more by the ICT push. 
Table 6.3: IPD Readiness Score- Case A

\begin{tabular}{|c|c|c|c|}
\hline Principle & Score & Source & Remarks \\
\hline EIKP & 5 & $\begin{array}{l}\text { - Article } 2.2 \text { of agreement between owner } \\
\text { and A/E. } \\
\text { - Article } 3.2 .1 \text { of agreement between } \\
\text { owner and construction manager. } \\
\text { - Interview with FIU and DPR Project } \\
\text { Manager for SCC Project. }\end{array}$ & $\begin{array}{l}\text { - A/E was involved at programming } \\
\text { stage } \\
\text { - } \mathrm{CM} / \mathrm{GC} \text { was involved at SD stage. } \\
\text { - Sub contractors were involved at } \mathrm{CD} \\
\text { phase. }\end{array}$ \\
\hline CDM & 2.5 & $\begin{array}{l}\text { Article } 3.2 .5 \text { of agreement between } \\
\text { owner and construction manager. } \\
\text { - Article } 5 \text { of agreement between owner } \\
\text { and construction manager. } \\
\text { - Interview with CM's Project manager. }\end{array}$ & $\begin{array}{l}\text { - } \mathrm{CM} / \mathrm{GC} \text { firm was responsible to } \\
\text { making recommendations. Final } \\
\text { decision makers were Owners or } \mathrm{A} / \mathrm{E} \\
\text { on behalf of owner. }\end{array}$ \\
\hline ID & 7.5 & $\begin{array}{l}\text { - Article } 2.2 \text { of agreement between owner } \\
\text { and A/E. } \\
\text { - Article } 3.2 .8 \text { of agreement between } \\
\text { owner and construction manager. } \\
\text { - Article } 3.2 .1 \text { of agreement between } \\
\text { owner and construction manager. }\end{array}$ & $\begin{array}{l}-\mathrm{CM} / \mathrm{GC} \text { was involved at } \mathrm{SD} \text { stage. } \\
\text { - Sub contractors were involved at } \mathrm{CD} \\
\text { phase. } \\
\text { - Bi-weekly meetings were conducted } \\
\text { during the design phases of the } \\
\text { project. }\end{array}$ \\
\hline JDPTC & 2.5 & $\begin{array}{l}\text { - Article } 5 \text {, "Construction Cost" of } \\
\text { agreement between owner and A/E. } \\
\text { - Article } 3.2 .1 \text { of agreement between } \\
\text { owner and construction manager. } \\
\text { - SCC Outline Program Document } \\
\end{array}$ & $\begin{array}{l}\text { - Owner determined the construction } \\
\text { project cost and it was mentioned as } \\
\text { construction cost in } \mathrm{A} / \mathrm{E} \text { and } \mathrm{CM} \\
\text { agreements. }\end{array}$ \\
\hline FT & 2.5 & $\begin{array}{l}\text { - Article } 11.3 \text { of the Owner }-\mathrm{A} / \mathrm{E} \\
\text { agreement. } \\
\text { - Article } 3.3 .12 \text { and } 3.3 .13 \text { of agreement } \\
\text { between owner and } \mathrm{CM} / \mathrm{GC}\end{array}$ & $\begin{array}{l}\text { - All books were open by A/E, } \\
\text { consultants, contactors, subcontractors }\end{array}$ \\
\hline SRR & $\mathbf{0}$ & $\begin{array}{l}\text { - Article } 11.1 \text { of the agreement between } \\
\text { owner and A/E. } \\
\text { - Article } 7.3 \text { of agreement between } \\
\text { owner and construction manager. }\end{array}$ & $\begin{array}{l}-\mathrm{A} / \mathrm{E} \text { were paid on lump sum basis for } \\
\text { the services, } \mathrm{CM} / \mathrm{GC} \text { were paid on } \\
\text { lump sum basis during preconstruction } \\
\text { phase }\end{array}$ \\
\hline LWKP & $\mathbf{0}$ & & No mutual liability waivers. \\
\hline MRT & 2.5 & $\begin{array}{l}\text { - Professional Qualifications } \\
\text { Supplement for A/E } \\
\text { - Construction Manager Qualifications } \\
\text { Supplement } \\
\text { - Project Correspondence Files (SD, DD, } \\
\text { CD, Construction) } \\
\text { - DPR Website and Articles about SCC. }\end{array}$ & $\begin{array}{l}- \text { Prior to this project, DPR and P+W } \\
\text { worked on more than } 40 \text { projects } \\
\text { throughout the country } \bullet \text { No evidence } \\
\text { of trust building workshops was found } \\
\text { - Trust competence was not the part of } \\
\text { PQS or CMQS. }\end{array}$ \\
\hline WTC & 5 & $\begin{array}{l}\text { - Interviews with FIU and DPR Project } \\
\text { managers } \\
\text { - Project Correspondence Files (SD, DD, } \\
\text { CD, Construction) }\end{array}$ & $\begin{array}{l}\text { Project participants were informally } \\
\text { committed to collaboration. }\end{array}$ \\
\hline OC & 5 & $\begin{array}{l}\text { - Article } 3.2 .8 \text { of agreement between } \\
\text { owner and construction manager. } \\
\text { - Article } 2.7 .5 \text { of agreement between } \\
\text { owner and A/E. } \\
\text { Interviews with FIU and DPR Project } \\
\text { managers } \\
\text { - Project Correspondence Files (SD, DD, } \\
\text { CD, Construction) and RFI Logs }\end{array}$ & $\begin{array}{l}\text { - All communication between the } \\
\text { owner and the Architect shall be } \\
\text { conducted through the FIU Project } \\
\text { Manager. The Architect will } \\
\text { communicate to CM and not directly } \\
\text { with the subcontractor on the project. } \\
\text { CMiC was shared between all project } \\
\text { participants }\end{array}$ \\
\hline Total & 32.5 & & \\
\hline
\end{tabular}


To determine the levels of ICT use for performing each function of the project, the step is analyzing each project function for its ICT use. Next section discusses the ICT levels used on this project.

\subsubsection{DETERMINATION OF ICT LEVEL}

Table 6.4 shows the ICT level of defined project function. It can be observed that the level of ICT use was least at the programming phase where all project functions were performed using level I ICT. The later stages show combination of tools used at all three levels of ICT which indicates that the level of ICT use is not homogenous throughout the project.

Table 6.4: Determination of ICT Level- Case- A

\begin{tabular}{|l|c|l|}
\hline Function & $\begin{array}{l}\text { ICT } \\
\text { Level }\end{array}$ & Remarks \\
\hline P1 & I & Manual development and qualitative selection \\
\hline P2 & I & Manual Estimating process \\
\hline P3 & I & Manual Scheduling process \\
\hline SD1 & III & Revit 3D \\
\hline SD2 & I & Specifications without links to source data or design \\
\hline SD3 & I & Use of standalone spreadsheet tools. \\
\hline SD4 & III & Navisworks \\
\hline DD1 & III & Revit 3D \\
\hline DD2 & III & Navisworks \\
\hline DD3 & I & Primavera (P6) \\
\hline CD1 & III & Navisworks \\
\hline CD2 & III & Revit 3D \\
\hline CD3 & I & Specifications without links to source data or design \\
\hline CD4 & I & Primavera (P6) \\
\hline C1 & III & 1. Navisworks 2. Buzzsaw \\
\hline C2 & II & $\begin{array}{l}\text { Planning meetings utilize the electronic projection of the } \\
\text { scheduling software. }\end{array}$ \\
\hline C3 & II & CMiC Project Management (shared with A/E, Owners and Subs) \\
\hline C4 & I & Manual Wet signed \\
\hline C5 & I & Manual copies of all records are maintained \\
\hline C6 & II & OurPlan (Digital planning and controlling tool) \\
\hline
\end{tabular}




\subsubsection{IPD READINESS REPORT}

Table 6.5 provides the IPD readiness report for the ICT push principles. For CDM it can be noted that while higher level ICT tools use is common for the functions that related to collaborative decision making the IPD readiness score that depends upon the on the way the owner delegates authority to project participants to take decisions. The lower

score indicates that the owners controls the decision making related to project and although the capacity to make more collaborative decision is present it is not practically exercised and the opportunities of improvement are missed.

Similarly, the IPD readiness of this project related to 'intensified design' is towards higher side ( 7.5 on scale of 10$)$ and the functions effected by this principle are also utilizing higher levels of ICT. This combination has the potential to strengthen the project. The result of this phenomenon is also reflected in the project process. For example, until the time of collection of data for case study (April 2014), the project had 39 change orders. The major reasons for additive change orders for the project are scope additions requested by owners. The major reasons for deductive change orders were to adjust the GMP for the credits for owners direct purchase orders. The high level of collaboration that took place between the project participants considerably reduced the change orders for reworks and delays to minimal.

The push effect of ICT is also evident on the WTC and OC. One indicator of which is the request for information (RFI). The total number of RFIs generated during the construction phase of the project was 658. The total cost of the project was $\$ 40,502,708.58$. The normalized number of RFIs on this project is about 16 RFIs per 
million dollars of project cost. This number is high in comparison to 10 RFIs per million dollars of project cost on a non - IPD project reported by El Asmar et. al. (2013) The RFI processing time was calculated by finding the difference between time date generated and date responded. The average processing time on the project came out to be 16 days. The number is slightly higher than the reported 2 weeks processing time for non - IPD projects by El Asmar et. al. (2013).

Table 6.5: IPD Readiness Report Case-A

\begin{tabular}{|l|c|c|c|c|c|c|}
\hline & $\mathbf{C D M}=\mathbf{2 . 5}$ & $\mathbf{J D P T C}=\mathbf{2 . 5}$ & $\mathbf{I D}=\mathbf{7 . 5}$ & $\mathbf{O C}=\mathbf{5}$ & $\mathbf{W T C}=\mathbf{5}$ & $\mathbf{F T}=\mathbf{2 . 5}$ \\
\hline PI & & I & & & I & \\
\hline P2 & & I & & & & \\
\hline P3 & & I & & & & \\
\hline SD1 & & III & III & & & \\
\hline SD2 & & I & I & & & \\
\hline SD3 & I & I & & & & \\
\hline SD4 & III & III & III & & & \\
\hline DD1 & & & III & III & III & \\
\hline DD2 & III & & III & III & & \\
\hline DD3 & I & & I & I & I & \\
\hline CD1 & III & & III & III & III & \\
\hline CD2 & & & III & & & \\
\hline CD3 & & & I & & & \\
\hline CD4 & I & & & I & I & \\
\hline C1 & III & & & III & III & \\
\hline C2 & II & & & II & II & \\
\hline C3 & II & & & II & II & \\
\hline C4 & & & & & & I \\
\hline C5 & I & & & & I & I \\
\hline C6 & II & & & II & II & \\
\hline
\end{tabular}

\subsubsection{CASE B- SCHOOL OF INTERNATIONAL AND PUBLIC AFFAIRS}

The School of International and Public Affairs (SIPA) is situated on the west side of Florida International University's Modesto A. Maidique Campus. The building consists of five floor levels and a two-story "floating in air auditorium with a footprint of 
58,238 sf. The building jointly serves International Studies and the International School. It provides a state-of-the art venue for the many activities - classes, lectures, workshops, performances, conferences, and faculty and graduate student research. Arquitectonica designed this predominantly precast concrete structure, and $\mathrm{CM} / \mathrm{GC}$ for the project was Suffolk Construction. The SIPA building was opened in 2011and it is the first building on FIU to achieve LEED Gold rating.

The Salient features of the building include;

- Two-story Ruth K. and Shepard Broad Auditorium that cantilevers 40 feet outwards and 17 feet off the ground.

- South Florida's largest green roof planted with native plants and photovoltaic solar panels on the highest roof. It is FIU's first building to achieve LEED gold rating and many awards for its sustainable construction including Sustainable Design Award by American Institute of Architects (AIA)-Florida.

Initially owners decided that the project will be delivered through design-bidbuild (DBB) or hard bid method. A/E selection process started in late 2005 and after a long round of prequalification and negotiations, ARQ was finally selected as A/E for the project and notice to proceed was served in June 2006.

Later in the schematic design phase (October 2007), owners realized that due to the problems faced in the project, it will be in the best interest of the project that if project is delivered using CM at-risk delivery method rather than the hard bid. In August 2008 it was formally decided that the project will be delivered using $\mathrm{CM}$ at-risk method. Information was communicated to $\mathrm{A} / \mathrm{E}$ and advertisement for $\mathrm{CM}$ selection was posted. The long process of selection of $\mathrm{CM} / \mathrm{GC}$ ended in Mid January 2014 when Notice to 
proceed was given to Suffolk Construction Co., Inc (SCCI) for the preconstruction services.

\subsubsection{PROJECT DESCRIPTION}

Project Name: School of International and Public Affairs (BT- 835)

Location: FIU Modesto A. Maidique Campus

Building Type: Educational

Owner: Florida International University (FIU)

Architect: Arquitectonica (ARQ)

Contractor: Suffolk Construction Co., Inc (SCCI)

Project Start Date: July 2, 2009

Estimated finish date: September 10, 2010

Project Finish Date: January 7, 2011

Footprint Area: 58,238 sq.-ft.

\subsubsection{DETERMINATION OF IPD READINESS SCORE}

Table 6.6 reflects the IPD readiness score for case-B. The aggregate score for the case came out to be 15 . This score is considerably low. Although CM-at-risk delivery method enhances collaboration between the project participants, the collaboration on this project was rather close to tradition DBB method. This could be related to the late inclusion of $\mathrm{CM}$ during the advanced design development phase. 
Table 6.6: IPD Readiness Score- Case B

\begin{tabular}{|c|c|c|c|}
\hline Principle & Score & Source & Remarks \\
\hline EIKP & 2.5 & $\begin{array}{l}\text { - Article } 2 \text { and } 11 \text { of agreement } \\
\text { between owner and A/E. } \\
\text { - Article } 2.1 \text { of agreement between } \\
\text { owner and construction manager. } \\
\text { - Subcontracts }\end{array}$ & $\begin{array}{l}\text { - A/E was involved at programming } \\
\text { stage } \\
\text { - } \mathrm{CM} / \mathrm{GC} \text { was involved at DD stage. } \\
\text { - Sub contractors were involved at } \\
\text { construction documentation phase }\end{array}$ \\
\hline CDM & 2.5 & $\begin{array}{l}\text { - Article } 2 \text { and } 11 \text { of agreement } \\
\text { between owner and A/E. } \\
\text { - Article } 2.1 \text { of agreement between } \\
\text { owner and construction manager. }\end{array}$ & $\begin{array}{l}\text { - Decision making for the majority of } \\
\text { pre-construction was done without the } \\
\text { inputs of CM. }\end{array}$ \\
\hline ID & 2.5 & $\begin{array}{l}\text { - Article } 2 \text { and } 11 \text { of agreement } \\
\text { between owner and A/E. } \\
\text { - Article } 2.1 \text { of agreement between } \\
\text { owner and construction manager. } \\
\text { - Subcontracts }\end{array}$ & $\begin{array}{l}\text { - Design efforts were performed in } \\
\text { rather traditional manner with } \\
\text { minimal input of CM and } \\
\text { subcontractors }\end{array}$ \\
\hline JDPTC & 2.5 & $\begin{array}{l}\text { - Article } 5 \text {, "Construction Cost" of } \\
\text { agreement between owner and A/E. } \\
\text { - Article 2.2.1 of agreement between } \\
\text { owner and construction manager. } \\
\text { - SCC Outline Program Document }\end{array}$ & $\begin{array}{l}\text { - Owner determined the construction } \\
\text { project cost and it was mentioned as } \\
\text { construction cost in } \mathrm{A} / \mathrm{E} \text { and } \mathrm{CM} \\
\text { agreements. }\end{array}$ \\
\hline FT & 2.5 & $\begin{array}{l}\text { - Article } 11.5 \text { of the Owner }-\mathrm{A} / \mathrm{E} \\
\text { agreement. } \\
\text { - Article } 2.2 .12 \text { and } 2.2 .13 \text { of } \\
\text { agreement between owner and } \\
\text { construction manager. }\end{array}$ & $\begin{array}{l}\text { - All books were open by } \mathrm{A} / \mathrm{E} \text {, } \\
\text { consultants, contactors, } \\
\text { subcontractors }\end{array}$ \\
\hline SRR & $\mathbf{0}$ & $\begin{array}{l}\text { - Article } 11 \text { of the agreement between } \\
\text { owner and A/E. } \\
\text { - Article } 7.3 \text { of agreement between } \\
\text { owner and construction manager. }\end{array}$ & $\begin{array}{l}\text { - } \mathrm{A} / \mathrm{E} \text { and } \mathrm{CM} / \mathrm{GC} \text { were paid on } \\
\text { lump sum basis for the pre- } \\
\text { construction services, } \\
\text { - According to C/M agreement "all } \\
\text { savings for the not-to-exceed value of } \\
\text { GMP shall be returned to owner". }\end{array}$ \\
\hline LWKP & $\mathbf{0}$ & & No mutual liability waivers. \\
\hline MRT & $\mathbf{0}$ & $\begin{array}{l}- \text { Professional Qualifications } \\
\text { Supplement for A/E } \\
\text { - Construction Manager Qualifications } \\
\text { Supplement } \\
\text { - Project Correspondence Files (SD, } \\
\text { DD, CD, Construction) }\end{array}$ & $\begin{array}{l}\text { - Team had no prior working } \\
\text { experience } \\
\text { - No evidence of trust building } \\
\text { workshops was found } \\
\text { - Trust competence is not the part of } \\
\text { PQS or CMQS. }\end{array}$ \\
\hline WTC & $\mathbf{0}$ & $\begin{array}{l}\text { - Interviews with Suffolk Project } \\
\text { managers } \\
\text { • Project Correspondence Files (SD, } \\
\text { DD, CD, Construction) }\end{array}$ & $\begin{array}{l}\text { - Due to late inclusion of CM and } \\
\text { business setup the project was closer } \\
\text { to DBB project delivery. }\end{array}$ \\
\hline OC & 2.5 & $\begin{array}{l}\text { - Article } 2.2 .8 \text { of agreement between } \\
\text { owner and construction manager. } \\
\text { - Article } 2.7 .8 \text { of agreement between } \\
\text { owner and A/E. } \\
\text { - Minutes of Meetings } \\
\text { - RFI Logs }\end{array}$ & $\begin{array}{l}\text { - Email and RFIs were cc'd to all } \\
\text { relevant participants. } \\
\text { - A/E firm had expressed concerns } \\
\text { about the transfer of electronic date } \\
\text { file and its uses by Owner, CM and } \\
\text { subcontractors. }\end{array}$ \\
\hline Total & 15 & & \\
\hline
\end{tabular}


The score for IPD push principles, this case the aggregate score is 12.5 out of 60 . This is again very low score. The majority of the score component is due to ICT push principles. To determine the state of ICT use in the project, following section analyses each project function for its ICT use.

\subsubsection{DETERMINATION OF ICT LEVEL}

Table 6.7 shows the ICT level of defined project function. The majority of functions were performed at level I ICT. The only exception to it was function Cli.e. trade coordination function during the construction phase for which BIM tool "Navisworks" was utilized. Low levels indicate that ICT push was not prevalent.

Table 6.7: Determination of ICT Level- Case- B

\begin{tabular}{|l|c|l|}
\hline Function & ICT Levels & Remarks \\
\hline P1 & I & Manual development and qualitative selection \\
\hline P2 & I & Manual Estimating process \\
\hline P3 & I & Manual Scheduling process \\
\hline SD1 & I & 2D CAD \\
\hline SD2 & I & Specifications without links to source data or design \\
\hline SD3 & I & Use of standalone spreadsheet tools. \\
\hline SD4 & I & Paper-based Review \\
\hline DD1 & I & 2D CAD \\
\hline DD2 & I & Paper-based Review \\
\hline DD3 & I & Primavera (P3) \\
\hline CD1 & I & $\begin{array}{l}\text { Experienced based constructability review without any rigorous } \\
\text { analysis for current project }\end{array}$ \\
\hline CD2 & I & 2D CAD \\
\hline CD3 & I & Specifications without links to source data or design \\
\hline CD4 & I & Primavera (P3) \\
\hline C1 & III & Navisworks for clash detections \\
\hline C2 & I & $\begin{array}{l}\text { Planning meetings utilize conventional "sticky note" on } \\
\text { whiteboard method. }\end{array}$ \\
\hline C3 & I & OnTrac Project Management System for RFIs \\
\hline C4 & I & Manual Wet signed \\
\hline C5 & I & Manual copies of all records are maintained \\
\hline C6 & I & Primavera (P3) \\
\hline
\end{tabular}




\subsubsection{IPD READINESS REPORT}

Table 6.8 provides the IPD Readiness report for the ICT push principles. As mentioned above in the above to sections that overall readiness score and ICT level on this project were substantially low. The major reason for this was that the project delivery method at the beginning of the project was decided as hard bid and the project was conducted in this manner for most of the design phase. The results of this are also reflected from the project records.

The project had around 140 proposed changed orders (PCO) during the construction phase of the building. The major reasons for producing change orders were due to delays and rework required to inconsistencies in the design drawings and the CAD drawings provided to $\mathrm{CM}$ and subcontractors, which highlights the importance of intensified design. The other reasons were scope additions requested by owners and addition, modifications and replace of several items during the construction phase of the project. The project original cost was estimated to be $\$ 13,898,708.00$ and the final cost was $\$ 19,349,579.57$. Although it included a major scope, additions of Chill loop Extension, which added $\$ 1,621,925.00$ to the original estimate. However, the final cost of construction was still $\$ 3.8$ million over budget. Design errors not only increased the cost of the project but also added 118 days to original project finish date.

The localized benefits of using higher level ICT are reflected by RFI handling process. The project utilized OnTrac project management system for RFI related communication. The total number of RFIs generated during the construction phase of the project was 509. To normalize the RFI value and make it comparable to other projects based on the sizes, the number of RFI is divided by the project construction cost. The 
total cost of the project was $\$ 19,349,579.57$. Therefore the normalized number of RFIs on this project is about 26 RFIs per million dollars of project cost. This number is considerably high in comparison to the research results reported by El Asmar et al. (2013) according to which, there are about 10 RFIs per million dollars of project cost on a traditionally delivered project and 2 RFIs on IPD project.

RFI processing time was calculated by finding the difference between time date generated and date responded. The average processing time on the project came out to be 11.53 days. The performance is slightly better than the reported 2 weeks processing time for non - IPD projects as reported in the same study mentioned above (El Asmar et al. 2013).

Table 6.8: IPD Readiness Report Case-B

\begin{tabular}{|c|c|c|c|c|c|c|}
\hline & CDM $=2.5$ & JDPTC $=2.5$ & ID $=2.5$ & $\mathrm{OC}=2.5$ & WTC $=0$ & FT $=2.5$ \\
\hline PI & & I & & & I & \\
\hline P2 & & I & & & & \\
\hline P3 & & I & & & & \\
\hline SD1 & & I & I & & & \\
\hline SD2 & & I & I & & & \\
\hline SD3 & I & I & & & & \\
\hline SD4 & $\mathrm{I}$ & $\mathrm{I}$ & $\mathrm{I}$ & & & \\
\hline DD1 & & & I & I & I & \\
\hline $\mathrm{DD} 2$ & I & & I & I & & \\
\hline DD3 & $\mathrm{I}$ & & $\mathrm{I}$ & $\mathrm{I}$ & I & \\
\hline CD1 & $\mathrm{I}$ & & $\bar{I}$ & $\mathrm{I}$ & I & \\
\hline $\mathrm{CD} 2$ & & & I & & & \\
\hline CD3 & & & $\mathrm{I}$ & & & \\
\hline CD4 & $\mathrm{I}$ & & & $\mathrm{I}$ & $\mathrm{I}$ & \\
\hline $\mathrm{C} 1$ & III & & & III & III & \\
\hline $\mathrm{C} 2$ & $\mathrm{I}$ & & & $\mathrm{I}$ & I & \\
\hline $\mathrm{C} 3$ & I & & & I & I & \\
\hline $\mathrm{C} 4$ & & & & & & I \\
\hline $\mathrm{C} 5$ & $\mathrm{I}$ & & & & $\mathrm{I}$ & I \\
\hline C6 & I & & & $\mathrm{I}$ & $\mathrm{I}$ & \\
\hline
\end{tabular}




\subsubsection{CASE C- MARINE BIOLOGY BUILDING}

Marine Biology Laboratory Building is located on Key Biscayne campus of FIU on the North Miami waterfront. The facility is comprised of a three-story lab block attached to a cylindrical-shaped tower of the same height. The facility includes four 35seat classrooms, 50-seat wet seawater laboratory, an aquarium room, a library, and a lobby at the first floor. The remaining two floors contain research and teaching labs, many with a "wet wall" of aquariums to facilitate the research purposes. The design and building of the facility was challenging, as it had to meet stringent code requirements of the coastal region construction. Cylindrical tower inspired by European castles and special window construction were among the some salient features of the facility that makes it withstand the extreme weather conditions.

\subsubsection{PROJECT DESCRIPTION}

Project Name: Marine Biology Building (BR-888)

Location: Biscayne Bay Campus, FIU

Building Type: Educational

Owner: Florida International University

Architect: Spillis Candella DMJM

Contractor: Centex Rooney Construction Co., Project Delivery Method: CM-at-Risk

Project Start Date: June 92004

Project Finish Date: June 12, 2006

Foot Print Area: 48,000 sq.-ft. 


\subsubsection{DETERMINATION OF IPD READINESS SCORE}

In Table 6.9 the IPD readiness score for each of the IPD principles for case $\mathrm{C}$ are presented. These scores reflect the readiness of the project based on the information collected from the project files. It should be noted that the score for EIKP is given as 5 based on its closeness to the condition defined in scale. The contractors were involved at advanced schematic design (late SD) phase and there major inputs to design were at detail design phase. Similarly, the scores for ID, WTC and OC are also assigned based on scenarios of the real project being closest to the defined points on the respective IPD readiness scales for each of the principles. The total IPD readiness score for this project is 22.5 out of 100 . The score of ICT push principles is 15 out of 60 . Both these scores are considerably low.

To further analyze the case, the ICT tools and methods utilized to perform several project functions are analyzed and reported.

\subsubsection{DETERMINATION OF ICT LEVEL}

Table 6.10 shows the ICT level of defined project function. It can be observed that the majority of project function was performed using level I ICT tools and methods. The only exception is coordination with trades (C1) which was performed at level II. It indicates that for this project, ICT push was not prevalent which is also reflected in IPD Readiness scores. 
Table 6.9: IPD Readiness Score- Case C

\begin{tabular}{|c|c|c|c|}
\hline Principle & Score & Source & Remarks \\
\hline EIKP & 5 & $\begin{array}{l}\text { - Article } 2 \text { and } 11 \text { of agreement between } \\
\text { owner and A/E. } \\
\text { - Article } 2.1 .1 \text { of agreement between } \\
\text { owner and construction manager. } \\
\text { - Subcontracts }\end{array}$ & $\begin{array}{l}\text { - Architects were involved on the } \\
\text { project from SD phase } \\
\text { - CM/CG was involved at Adv. } \\
\text { Schematic Phase } \\
\text { - Subcontractors were involved in the } \\
\text { project at CD phase. }\end{array}$ \\
\hline CDM & 2.5 & $\begin{array}{l}\text { - Article } 2.1 .5 \text { of agreement between } \\
\text { owner and construction manager. }\end{array}$ & $\begin{array}{l}\text { - } \mathrm{CM} / \mathrm{CG} \text { basic services includes } \\
\text { making recommendations as required } \\
\text { for alternative solutions related to } \\
\text { design and construction feasibility. }\end{array}$ \\
\hline ID & 2.5 & $\begin{array}{l}\text { - Article } 2.1 .1 \text { and } 2.1 .8 \text { of agreement } \\
\text { between owner and construction } \\
\text { manager. } \\
\text { - Article } 2 \text { and } 11 \text { of agreement between } \\
\text { owner and A/E. } \\
\text { - Subcontract documents }\end{array}$ & $\begin{array}{l}- \text { Meetings were conducted monthly } \\
\text { by the construction team during } \\
\text { design phases } \\
\cdot \text { CM/CG was involved at Adv. } \\
\text { Schematic Phase } \\
\text { - Subcontractors were involved in the } \\
\text { project after CD phase. }\end{array}$ \\
\hline JDPTC & 2.5 & $\begin{array}{l}\text { - Article } 2 \text { and } 11 \text { of agreement between } \\
\text { owner and } \mathrm{A} / \mathrm{E} \text {. } \\
\text { - Article } 2.1 .1 \text { of agreement between } \\
\text { owner and construction manager. }\end{array}$ & $\begin{array}{l}\mathrm{CM} / \mathrm{GC} \text { was present early on the } \\
\text { project and progressively } \\
\text { recommended on the project criteria } \\
\text { but target criteria were approved by } \\
\text { Owners. }\end{array}$ \\
\hline FT & 2.5 & $\begin{array}{l}\text { - Article } 2.2 .12 \text { of agreement between } \\
\text { owner and construction manager. }\end{array}$ & $\begin{array}{l}\text { - Both contracts obligated participants } \\
\text { to maintain open books and defines } \\
\text { owner's right to audit the books. }\end{array}$ \\
\hline SRR & $\mathbf{0}$ & $\begin{array}{l}\text { - Article } 6.3 \text { of agreement between } \\
\text { owner and construction manager. } \\
\text { - Article } 11 \text { of agreement between } \\
\text { owner and A/E. }\end{array}$ & $\begin{array}{l}\text { - } \mathrm{A} / \mathrm{E} \text { and } \mathrm{CM} / \mathrm{GC} \text { were paid on } \\
\text { lump sum basis for the pre- } \\
\text { construction services, } \\
\text { - Savings were required to return to } \\
\text { owner. }\end{array}$ \\
\hline LWKP & $\mathbf{0}$ & & No mutual liability waivers. \\
\hline MRT & 2.5 & $\begin{array}{l}\text { - GMP File (GMP Review letter) } \\
\text { - Professional Qualifications } \\
\text { Supplement for A/E } \\
\text { - Construction Manager Qualifications } \\
\text { Supplement } \\
\text { - Project Correspondence Files (SD, } \\
\text { DD, CD, Construction) }\end{array}$ & $\begin{array}{l}\cdot \mathrm{CM} / \mathrm{GC} \text { and } \mathrm{A} / \mathrm{E} \text { had past working } \\
\text { relation. } \\
\cdot \mathrm{FIU} \text { had no past experience with } \\
\text { either } \mathrm{A} / \mathrm{E} \text { or } \mathrm{CM} / \mathrm{GC} \\
\text { - Trust competence was not a } \\
\text { selection criteria } \\
\text { - No record of trust building } \\
\text { workshops during the project }\end{array}$ \\
\hline WTC & 2.5 & $\begin{array}{l}\text { - Article } 6.3 \text { of agreement between } \\
\text { owner and construction manager. } \\
\text { - Project correspondence files of } \\
\text { SD,DD,CD and Construction phases }\end{array}$ & $\begin{array}{l}\text { - No alignment of goals among } \\
\text { project participants. } \\
\text { - A/E representatives were present on } \\
\text { site to facilitate the contractors. }\end{array}$ \\
\hline OC & 2.5 & $\begin{array}{l}\text { - Article } 2.2 .7 \text { of CM agreement } \\
\text { - Log of Minutes of meeting } \\
\text { - Construction phase correspondence } \\
\text { file }\end{array}$ & $\begin{array}{l}\text { - } \text { Conduct weekly meetings with trade } \\
\text { contractors.... } \\
\text { - Weekly OAC meetings during } \\
\text { design phase } \\
\text { - RFIs were required to be sent } \\
\text { through Fax to relevant participants. }\end{array}$ \\
\hline Total & 22.5 & & \\
\hline
\end{tabular}


Table 6.10: Determination of ICT Level- Case- C

\begin{tabular}{|l|c|l|}
\hline Function & $\begin{array}{l}\text { ICT } \\
\text { Level }\end{array}$ & Remarks \\
\hline P1 & I & Manual development and qualitative selection \\
\hline P2 & I & Manual Estimating process \\
\hline P3 & I & Manual Scheduling process \\
\hline SD1 & I & 2D CAD \\
\hline SD2 & I & Specifications without links to source data or design \\
\hline SD3 & I & Use of standalone spreadsheet tools. \\
\hline SD4 & I & Paper-based Review \\
\hline DD1 & I & 2D CAD \\
\hline DD2 & I & Paper-based Review \\
\hline DD3 & I & Primavera (P3) \\
\hline CD1 & I & $\begin{array}{l}\text { Experienced based constructability review utilizing 2D CAD } \\
\text { drawings }\end{array}$ \\
\hline CD2 & I & 2D CAD \\
\hline CD3 & I & Specifications without links to source data or design \\
\hline CD4 & I & Primavera (P3) \\
\hline C1 & II & 2D CAD overlays \\
\hline C2 & I & $\begin{array}{l}\text { Planning meetings utilize conventional "sticky note" on } \\
\text { whiteboard method. }\end{array}$ \\
\hline C3 & I & RFIs communication was done through fax \\
\hline C4 & I & Manual Wet signed \\
\hline C5 & I & Manual copies of all records are maintained \\
\hline C6 & I & Primavera (P3) \\
\hline
\end{tabular}

\subsubsection{IPD READINESS REPORT}

IPD readiness report for case- $\mathrm{C}$ is presented in Table 6.11. It is a 10 year old project whose construction started in June 2004. It can be observed that the level of ICT tools and methods for the majority project functions is at level I. Therefore ICT push is not a factor of influence of IPD readiness. This is justifiable to greater extent by the fact that being an older project many higher level ICT tools were not common at the time of design and construction of this project.

As observed, for this project, RFI handling process was mandated through Fax. Information from the project files revealed that the responses to RFIs were hand written 
and faxed back to $\mathrm{CM} / \mathrm{CG}$ who then communicated the information to subcontractors. This chain of communication was long and inefficient. The total number of RFIs generated during the construction phase of the project was 326 . Therefore the normalized number of RFIs on this project is about 30 RFIs per million dollars of project cost. This number is considerably high in comparison to the research results reported by El Asmar et al. (2013) and in comparison to other case projects discussed. RFI processing time was found to be 19.23 days.

Table 6.8: IPD readiness Report Case-C

\begin{tabular}{|l|c|c|c|c|c|c|}
\hline & $\mathbf{C D M}=\mathbf{2 . 5}$ & $\mathbf{J D P T C}=\mathbf{2 . 5}$ & $\mathbf{I D}=\mathbf{2 . 5}$ & $\mathbf{O C}=\mathbf{2 . 5}$ & $\mathbf{W T C}=\mathbf{2 . 5}$ & $\mathbf{F T}=\mathbf{2 . 5}$ \\
\hline PI & & I & & & I & \\
\hline P2 & & I & & & & \\
\hline P3 & & I & & & & \\
\hline SD1 & & I & I & & & \\
\hline SD2 & & I & I & & & \\
\hline SD3 & I & I & & & & \\
\hline SD4 & I & I & I & & & \\
\hline DD1 & & & I & I & I & \\
\hline DD2 & I & & I & I & & \\
\hline DD3 & I & & I & I & I & \\
\hline CD1 & I & & I & I & I & \\
\hline CD2 & & & I & & & \\
\hline CD3 & & & I & & & \\
\hline CD4 & I & & & I & I & \\
\hline C1 & II & & & II & II & \\
\hline C2 & I & & & I & I & \\
\hline C3 & I & & & I & I & \\
\hline C4 & & & & & & I \\
\hline C5 & I & & & & I & I \\
\hline C6 & I & & & I & I & \\
\hline
\end{tabular}

Considerable difference was also found between the estimated cost and schedule as compared to the actual cost and duration. The facility that was planned to be finished in 425 days however over 680 days to complete. A part of this increase is in duration was because two hurricanes Katrina and Wilma hit South Florida and resulted in suspended the activities. Rework due to repair also contributed to cost increase of the facility. 


\subsubsection{CASE D- PARKVIEW HOUSING}

Parkview housing is located Florida International University's Modesto A. Maidique Campus. It consist of two (2) construction phases each accommodating 620 beds. For this case study phase 1 of the facility is considered. Phase 2 is a future development plan with expected date of finish of 2016. This housing facility is designed by HADP and HKS as a joint venture and constructed by Moss \& Associates (CM/GC). The project was delivered through CM-At Risk due to the significant need to reduce normal delivery time and the size of project is sufficiently large and complex to require major emphasis on qualification of contractor with continuity of construction management through design and construction multiple phases.

\subsubsection{PROJECT DESCRIPTION}

Project Name: Parkview Housing Project- (BT-889)

Location: FIU Modesto A. Maidique Campus

Building Type: Residential

Owner: Florida International University (FIU)

Architect: HADP Architecture, Inc. /HKS Architects, Inc.- Joint Venture

Contractor: Moss \& Associates, a Florida Limited Liability Company (Moss)

Project Delivery Method: CM-at-Risk

Project Start Date: May 15, 2012

Finish Date: July 15, 2013

Footprint Area: 217,099 sq. $\mathrm{ft}$ 


\subsubsection{DETERMINATION OF IPD READINESS SCORE}

In Table 6.12, IPD readiness score for case-D is presented. The score are assigned to all the ten project principles based on the collected project information. For EIKP, ID the scores are assigned based on the closeness to the define point on the respective scales. The total score for this case came out to be 30 . This score is considerably low as compared to an ideal IPD project. The aggregate score for the six ICT push principles for case $\mathrm{D}$ is 25 out of 60 . If this aggregate score is compared with the total score of the case, it constitutes the majority of the score i.e. 25 (total of 30 ). So it can be said that this particular project can be influenced by ICT push. To further analyze this hypothesis, the ICT levels are assessed in the next section.

\subsubsection{DETERMINATION OF ICT LEVEL}

Table 6.13 shows the ICT levels for all the twenty project functions. It can be observed that the level of ICT use was least at the programming phase where all project functions were performed using level I ICT tools and methods. The later stages show a mix of tools and methods used at all three levels of ICT. It indicates that the level of ICT use is not homogenous throughout the project. To determine whether the particular combination resulted in any improvement in the way project was conducted; next section gives the IPD report and relates the findings to some performance indicators from the project. 
Table 6.9: IPD Readiness Score- Case D

\begin{tabular}{|c|c|c|c|}
\hline Principle & Score & Source & Remarks \\
\hline EIKP & 5 & $\begin{array}{l}\text { - Article 3.3of agreement between } \\
\text { owner and A/E. } \\
\text { - Article } 8.1 .1 \text { of agreement between } \\
\text { owner and construction manager. } \\
\text { - Interview with FIU's Project } \\
\text { Manager for Case D Project. }\end{array}$ & $\begin{array}{l}\text { - Both } \mathrm{A} / \mathrm{E} \text { and } \mathrm{CM} / \mathrm{GC} \text { were brought on } \\
\text { the project at SD stage. } \\
\text { - Subcontractors were not present till start } \\
\text { of construction phase although CM } \\
\text { collaborated with subs to develop GMP. }\end{array}$ \\
\hline CDM & 2.5 & $\begin{array}{l}\text { - Article } 3 \text { of agreement between } \\
\text { owner and construction manager. }\end{array}$ & $\begin{array}{l}\text { - } \mathrm{CM} / \mathrm{GC} \text { firm was responsible to making } \\
\text { recommendations. Final decision makers } \\
\text { were Owners or } \mathrm{A} / \mathrm{E} \text { on behalf of owner. }\end{array}$ \\
\hline ID & 7.5 & $\begin{array}{l}\text { - Article } 3.3 \text { of agreement between } \\
\text { owner and } \mathrm{A} / \mathrm{E} \text {. } \\
\text { - Article } 3 \text { of agreement between } \\
\text { owner and construction manager. }\end{array}$ & $\begin{array}{l}\text { - } \mathrm{CM} / \mathrm{GC} \text { was involved at } \mathrm{SD} \text { stage. } \\
\text { - } \mathrm{Bi} \text {-weekly meetings were conducted } \\
\text { during the design phases of the project. }\end{array}$ \\
\hline JDPTC & 2.5 & $\begin{array}{l}\text { - Article } 6.12 \text { of agreement between } \\
\text { owner and A/E. } \\
\text { - Article } 3.2 .1 \text { of agreement between } \\
\text { owner and construction manager. } \\
\text { - Outline Program Document }\end{array}$ & $\begin{array}{l}\text { - Owner determined the construction } \\
\text { project cost and it was mentioned as } \\
\text { construction cost in } \mathrm{A} / \mathrm{E} \text { and } \mathrm{CM} \\
\text { agreements. }\end{array}$ \\
\hline FT & 2.5 & $\begin{array}{l}- \text { Article } 12.5 \text { of the Owner }-\mathrm{A} / \mathrm{E} \\
\text { agreement. } \\
\text { - Article } 3.3 .12 \text { and } 3.3 .13 \text { of } \\
\text { agreement between owner and } \\
\text { construction manager. }\end{array}$ & $\begin{array}{l}\text { - All books were open by } \mathrm{A} / \mathrm{E} \text {, consultants, } \\
\text { contactors, subcontractors }\end{array}$ \\
\hline SRR & $\mathbf{0}$ & $\begin{array}{l}\text { - Article } 12.1 \text { of the agreement } \\
\text { between owner and } \mathrm{A} / \mathrm{E} \text {. } \\
\text { - Article } 8.1 .1 \text { of agreement between } \\
\text { owner and construction manager. }\end{array}$ & $\begin{array}{l}\text { - A/E an CM were paid on lump sum basis } \\
\text { during preconstruction phase } \\
\text { - Article } 7.3 \text { of } \mathrm{C} / \mathrm{M} \text { agreement explicit } \\
\text { that all savings shall be returned to owner. }\end{array}$ \\
\hline LWKP & $\mathbf{0}$ & & No mutual liability waivers. \\
\hline MRT & 2.5 & $\begin{array}{l}\text { - Professional Qualifications } \\
\text { Supplement for A/E } \\
\text { - Construction Manager } \\
\text { Qualifications Supplement } \\
\text { - Project Correspondence Files (SD, } \\
\text { DD, CD, Construction) } \\
\text { - Interviews with CM and architect. }\end{array}$ & $\begin{array}{l}\text { - No evidence of trust building workshops } \\
\text { was found } \\
\text { - Trust competence was not the part of } \\
\text { PQS or CMQS. } \\
\text { A/E had past working relation with both } \\
\text { owner and CM. It was CMs first project } \\
\text { with Owners. }\end{array}$ \\
\hline WTC & 5 & $\begin{array}{l}\text { - Interviews with FIU and Moss } \\
\text { Project managers } \\
\text { - Project Correspondence Files (SD, } \\
\text { DD, CD, Construction) }\end{array}$ & $\begin{array}{l}\text { - Project participants were informally } \\
\text { committed to collaboration. } \\
\text { - There was an onsite full time architect } \\
\text { that helped CM work through any issues. }\end{array}$ \\
\hline OC & 2.5 & $\begin{array}{l}- \text { Project Procedures Manual of } \\
\text { Construction Operation } \\
\text { - Project correspondence files (SD, } \\
\text { DD, CD, Construction) and RFI } \\
\text { Logs }\end{array}$ & $\begin{array}{l}\text { - Long transmission chain } \\
\text { - FIU was not copied on to the } \\
\text { communication between A/E and CM } \\
\text { other than specific occasions }\end{array}$ \\
\hline Total & 30 & & \\
\hline
\end{tabular}


Table 6.10: Determination of ICT Level- Case- D

\begin{tabular}{|l|c|l|}
\hline Function & $\begin{array}{l}\text { ICT } \\
\text { Level }\end{array}$ & Remarks \\
\hline P1 & I & Manual development and qualitative selection \\
\hline P2 & I & Manual Estimating process \\
\hline P3 & I & Manual Scheduling process \\
\hline SD1 & III & Revit 3D \\
\hline SD2 & I & Specifications without links to source data or design \\
\hline SD3 & I & Use of standalone spreadsheet tools. \\
\hline SD4 & III & Navisworks \\
\hline DD1 & III & Revit 3D \\
\hline DD2 & III & Navisworks \\
\hline DD3 & II & 4Clicks (software with 2012 R.S. Means facilities cost data) \\
\hline CD1 & III & Navisworks \\
\hline CD2 & III & Revit 3D \\
\hline CD3 & I & Specifications without links to source data or design \\
\hline CD4 & II & Primavera (P6), 4Clicks \\
\hline C1 & III & 1. Navisworks 2. Buzzsaw \\
\hline C2 & II & $\begin{array}{l}\text { Planning meetings utilize the electronic projection of the BIM } \\
\text { model. }\end{array}$ \\
\hline C3 & I & CMiC Project Management (for CM use only) \\
\hline C4 & I & Manual Wet signed \\
\hline C5 & I & Manual copies of all records are maintained \\
\hline C6 & I & $\begin{array}{l}\text { Forecasting reports are manually generated based on progress } \\
\text { reports. }\end{array}$ \\
\hline
\end{tabular}

\subsubsection{IPD READINESS REPORT}

The IPD readiness scores and the ICT levels for the six ICT push principles are shown in Table 6.14 provides the. For CDM it can be noted that while higher level ICT tools use is frequent for the functions that related to collaborative decision making the IPD readiness score is still low. Thus indicates that ICT push can further be enhanced and can result in better collaborative decision making if the business setup is revised to take advantage from ICT tools.

IPD readiness of this project for intensified design is towards higher side is high ( 7.5 on scale of 10) and the functions affected by this principle are also utilizing higher 
levels of ICT. It is a potential area that can result in overall improvement of project delivery. The result of this phenomenon is also reflected in the project process. Although the project is complete, the project files are still open and some change orders are still in process. The agreed GMP for the project was $\$ 45,873,528$. Because of change orders, the contracted price came down to $\$ 39,807,463$. The major cause of reduction in cost was subtractive change orders due to the direct purchase order. The facility was completed on its anticipated date of completion without any delay. The major cause of additive change orders was cost of increased scope from owner. Increase of cost due to rework due to design errors was not found on this project. This also strengthens the finding that indentified design is well supported with available ICT push.

Table 6.11: IPD readiness Report Case-D

\begin{tabular}{|c|c|c|c|c|c|c|}
\hline & $C D M=2.5$ & JDPTC $=2.5$ & ID $=7.5$ & $\mathrm{OC}=2.5$ & $\mathbf{W T C}=5$ & FT $=2.5$ \\
\hline PI & & I & & & I & \\
\hline P2 & & I & & & & \\
\hline P3 & & $\bar{I}$ & & & & \\
\hline SD1 & & III & III & & & \\
\hline SD2 & & I & I & & & \\
\hline SD3 & I & $\mathrm{I}$ & & & & \\
\hline$\overline{\text { SD4 }}$ & III & III & III & & & \\
\hline DD1 & & & III & III & III & \\
\hline DD2 & III & & III & III & & \\
\hline DD3 & II & & II & II & II & \\
\hline CD1 & III & & III & III & III & \\
\hline $\mathrm{CD} 2$ & & & III & & & \\
\hline CD3 & & & $\mathrm{I}$ & & & \\
\hline CD4 & II & & & II & II & \\
\hline C1 & III & & & III & III & \\
\hline $\mathrm{C} 2$ & II & & & II & II & \\
\hline C3 & I & & & I & I & \\
\hline $\mathrm{C} 4$ & & & & & & I \\
\hline $\mathrm{C} 5$ & $\mathrm{I}$ & & & & $\mathrm{I}$ & $\mathrm{I}$ \\
\hline C6 & I & & & I & I & \\
\hline
\end{tabular}

The total number of RFIs generated during the construction phase of the project was 583. The total cost of the project was $\$ 39,807,463$. The normalized number of RFIs 
on this project is about 14.64 RFIs per million dollars of project cost. The average processing time on the project came out to be 15.5 days. The number is slightly higher than the reported 2 weeks processing time for non - IPD projects by El Asmar et al. (2013).

\subsubsection{CASE E- FROST ART MUSEUM}

Frost Art museum is a 4-story building on Modesto A. Maidique Campus of FIU. The major feature of the building includes nine exhibition galleries, a 4-story glass atrium at the entrance, a café and museum shop, and an outdoor sculpture deck that overhangs the lake. The project also includes an art studio classroom and a lecture hall for students.

\subsubsection{PROJECT DESCRIPTION}

Project Name: Patricia \& Phillip Frost Art Museum (FAM) (BR-839)

Location: FIU Modesto A. Maidique Campus

Building Type: Museum

Owner: Florida International University

Architect: Hellmuth, Obata \& Kassabam, Inc. (HOK)

Contractor: Skanska USA Building, Inc

Project Delivery Method: CM-at-Risk

Project Start Date: August 2, 2004

Project Finish Date: May 2007

Footprint Area: 46,000-sq ft. 


\subsubsection{DETERMINATION OF IPD READINESS SCORE}

Table 6.12: IPD Readiness Score- Case E

\begin{tabular}{|c|c|c|c|}
\hline Principle & Score & Source & Remarks \\
\hline EIKP & 5 & $\begin{array}{l}\text { - Article } 2 \text { and } 11 \text { of agreement } \\
\text { between owner and A/E. } \\
\text { - Article } 7.1 .1 \text { of agreement between } \\
\text { owner and construction manager. }\end{array}$ & $\begin{array}{l}-\mathrm{A} / \mathrm{E} \text { was involved on the project from SD } \\
\text { phase } \\
\text { - } \mathrm{CM} / \mathrm{CG} \text { was involved at Adv. Schematic } \\
\text { Phase } \\
\text { - Subs were involved at CD phase. }\end{array}$ \\
\hline CDM & 2.5 & $\begin{array}{l}\text { - Article } 2.1 .3-2.1 .5,2.2 .13 \text { of } \\
\text { agreement between owner and } \\
\text { construction manager. }\end{array}$ & $\begin{array}{l}\text { - } \mathrm{CM} / \mathrm{CG} \text { basic services include making } \\
\text { recommendations for alternative solutions } \\
\text { and design's construction feasibility. }\end{array}$ \\
\hline ID & 2.5 & $\begin{array}{l}\text { - Article } 2 \text { and } 11 \text { of agreement } \\
\text { between owner and A/E. } \\
\text { - Article } 7.1 .1 \text { of agreement between } \\
\text { owner and construction manager. }\end{array}$ & $\begin{array}{l}\text { - Meetings were conducted monthly by the } \\
\text { construction team during design phases }\end{array}$ \\
\hline JDPTC & 2.5 & $\begin{array}{l}\text { - Article } 2 \text { of agreement between owner } \\
\text { and A/E. } \\
\text { - Article } 2.1 .2 \text { of agreement between } \\
\text { owner and construction manager. }\end{array}$ & $\begin{array}{l}\mathrm{CM} / \mathrm{GC} \text { was present early on the project } \\
\text { and progressively recommended on the } \\
\text { project criteria but target criteria were } \\
\text { approved by Owners. }\end{array}$ \\
\hline FT & 2.5 & $\begin{array}{l}\text { - Article } 2.2 .12 \text { of agreement between } \\
\text { owner and construction manager. }\end{array}$ & $\begin{array}{l}\cdot \text { Both } \mathrm{A} / \mathrm{E} \text { and } \mathrm{CM} \text { contracts obligate } \\
\text { them to maintain open books. }\end{array}$ \\
\hline SRR & $\mathbf{0}$ & $\begin{array}{l}\text { - Article } 6.3 \text { of agreement between } \\
\text { owner and construction manager. } \\
\text { - Article } 11 \text { of agreement between } \\
\text { owner and A/E. }\end{array}$ & $\begin{array}{l}\text { - } \mathrm{A} / \mathrm{E} \text { and } \mathrm{CM} / \mathrm{GC} \text { were paid on lump } \\
\text { sum basis for the pre-construction services, } \\
\text { - Savings were required to return to owner. }\end{array}$ \\
\hline LWKP & $\mathbf{0}$ & & No mutual liability waivers. \\
\hline MRT & 2.5 & $\begin{array}{l}\text { - PQS for A/E and CMQS for CM } \\
\text { - Project Correspondence Files (SD, } \\
\text { DD, CD, Construction) } \\
\text { - Websites of } \mathrm{A} / \mathrm{E} \text { and } \mathrm{CM}\end{array}$ & $\begin{array}{l}\cdot \mathrm{CM} / \mathrm{GC} \text { and } \mathrm{A} / \mathrm{E} \text { had past working } \\
\text { relation., FIU has no past working relation } \\
\text { with } \mathrm{CM} / \mathrm{GC} \\
\text { - Trust competence was not a selection } \\
\text { criteria }\end{array}$ \\
\hline WTC & $\mathbf{0}$ & $\begin{array}{l}\text { - Article } 6.3 \text { of agreement between } \\
\text { owner and construction manager. } \\
\text { - Project correspondence files of } \\
\text { SD,DD,CD and Construction phases }\end{array}$ & $\begin{array}{l}\text { No alignment of goals among project } \\
\text { participants. } \\
\text { - Team members mostly resided in separate } \\
\text { offices. }\end{array}$ \\
\hline $\mathrm{OC}$ & 2.5 & $\begin{array}{l}- \text { Article } 2.2 .7 \text { of CM agreement } \\
\text { - Log of Minutes of meeting } \\
\text { - RFI logs }\end{array}$ & $\begin{array}{l}\text { - Weekly meetings with trade contractors. } \\
\text { - Weekly OAC meetings } \\
\text { - RFIs were managed through separate } \\
\text { systems by A/E and CM. }\end{array}$ \\
\hline Total & 20 & & \\
\hline
\end{tabular}

Table 6.15 reflects the IPD readiness score for each of the IPD principles for case

C. The total IPD readiness score for this project is 20 out of 100 . It is due to the fact that the project scored in low range $(0-2.5)$ for the majority of IPD principles. Further 
distribution of IPD readiness score among ICT push and IPD pull principles revealed that the score for six ICT push principles is 15 out of 60 as compared to 5 out of 40 for the IPD pull principles.

\subsubsection{DETERMINATION OF ICT LEVEL}

ICT level for the defined project functions are shown in Table 6.16. It can be observed that the majority of project functions were performed at level I ICT. The few exceptions to this are project functions Sd4, DD2 and $\mathrm{C} 1$ that are performed by utilizing level II ICT tools and methods.

Table 6.13: Determination of ICT Level- Case- E

\begin{tabular}{|l|c|l|}
\hline Function & ICT Level & Remarks \\
\hline P1 & I & Manual development and qualitative selection \\
\hline P2 & I & Manual Estimating process \\
\hline P3 & I & Manual Scheduling process \\
\hline SD1 & I & 2D CAD \\
\hline SD2 & I & Specifications without links to source data or design \\
\hline SD3 & I & Use of standalone spreadsheet tools. \\
\hline SD4 & II & Prolog Application Suite \\
\hline DD1 & I & 2D CAD \\
\hline DD2 & II & Prolog Application Suite \\
\hline DD3 & I & Primavera (P3), Prolog Application Suite \\
\hline CD1 & I & $\begin{array}{l}\text { Experienced based constructability review without decision support } \\
\text { system }\end{array}$ \\
\hline CD2 & I & 2D CAD \\
\hline CD3 & I & Specifications without links to source data or design \\
\hline CD4 & I & Primavera (P3), Prolog Application Suite \\
\hline C1 & II & 2D CAD overlays \\
\hline C2 & I & Planning meetings utilize “sticky note" on whiteboard method \\
\hline C3 & I & RFIs communication was done through fax \\
\hline C4 & I & Manual Wet signed \\
\hline C5 & I & Manual copies of all records are maintained \\
\hline C6 & I & Primavera (P3), Prolog Application Suite \\
\hline
\end{tabular}




\subsubsection{IPD READINESS REPORT}

Table 6.17 gives the IPD readiness report for case- E. It. It can be observed that the level of ICT use for the project is mostly at level I and the IPD readiness scores for all the six ICT push principles are low. Therefore, it can be said that there is a correlation between the IPD readiness scores and ICT levels.

Table 6.17: IPD Readiness Report Case-E

\begin{tabular}{|c|c|c|c|c|c|c|}
\hline & $\mathrm{CDM}=2.5$ & JDPTC $=2.5$ & ID $=2.5$ & $\mathrm{OC}=2.5$ & $\mathbf{W T C}=\mathbf{0}$ & $\mathrm{FT}=2.5$ \\
\hline PI & & I & & & I & \\
\hline $\mathrm{P} 2$ & & I & & & & \\
\hline P3 & & I & & & & \\
\hline SD1 & & I & I & & & \\
\hline SD2 & & I & I & & & \\
\hline SD3 & I & I & & & & \\
\hline SD4 & II & II & II & & & \\
\hline DD1 & & & I & I & I & \\
\hline DD2 & II & & II & II & & \\
\hline DD3 & I & & I & I & $\mathrm{I}$ & \\
\hline CD1 & I & & I & I & $\mathrm{I}$ & \\
\hline CD2 & & & I & & & \\
\hline CD3 & & & I & & & \\
\hline CD4 & I & & & I & I & \\
\hline $\mathrm{C} 1$ & II & & & II & II & \\
\hline $\mathrm{C} 2$ & $\mathrm{I}$ & & & I & I & \\
\hline $\mathrm{C} 3$ & I & & & I & I & \\
\hline $\mathrm{C} 4$ & & & & & & I \\
\hline $\mathrm{C} 5$ & $\mathrm{I}$ & & & & $\mathrm{I}$ & $\mathrm{I}$ \\
\hline C6 & I & & & I & $\mathrm{I}$ & \\
\hline
\end{tabular}

Further analysis of the project information revealed that considerable difference was found between the estimated cost and schedule as compared to the actual cost and duration. The original contract sum was $\$ 11,157,703$; the project finished with the construction cost equal to $\$ 15,138,816$. Significant difference was also observed in duration where the facility that was planned to be finished in 693 days and the project took 1020 days to complete. Like the Case C, a part of this increase is due to the fact that 
two hurricanes Katrina and Wilma hit the project sit and suspended the activities. Also damages to the site had to be repaired that added to the cost and schedule of the project.

\subsubsection{CASE F- MIXED USE COLLEGE OF BUSINESS BUILDING (MANGO)}

MANGO is a mixed used building that will serve the increasing needs of three departments at FIU. It is on-going project that is still under construction at the time of this report. The College of Business Administration, FIU Online and Business Services will share the facility with designated floor for each department. The GMP for the construction cost is approximately $\$ 27,000,000$. The University is targeting to comply with sustainable energy conservation strategies and standards (minimum LEED Silver Certification).

\subsubsection{PROJECT DESCRIPTION}

Project Name: Mixed Use College of Business Building (MANGO) BT-886

Location: FIU Modesto A. Maidique Campus

Building Type: Educational

Owner: Florida International University (FIU)

Architect: Hellmuth, Obata + Kassabam, Inc. (HOK)

Contractor: Arrellano Construction

Project Delivery Method: CM-at-Risk

Project Start Date: July 2013

Expected Finish Date: July 2014

Footprint Area: 106,611sq. ft 


\subsubsection{DETERMINATION OF IPD READINESS SCORE}

The IPD readiness score for case-F is presented in table 6.18. The total IPD readiness score for this project is 35 . This comparatively higher score of the project can be attributed to better readiness assessed for of the ID, EIKP, WTC and OC. The project information revealed that early involvement and higher level of collaboration between the project participants that resulted in achieving collaborative and behavioral IPD principles to a higher extent. The cumulative score for ICT Push principles is 27.5 out of 60 .

The IPD readiness scores for ICT push principles are the majority of the score for this project. This indicates that this project has the potential to be influenced by the ICT levels are assessed in next section.

\subsubsection{DETERMINATION OF ICT LEVEL}

ICT level for each of the twenty project functions are illustrated in Table 6.19. Again the level of ICT tools and methods at the programming stage are majorly Level I ICTs as compared to other stages where combination of ICT tools and methods are utilized ranging from level to level III. It can be observed that several level III ICT tools and methods are utilized to perform the project. This higher-level use can be associated with more hi-tech tools becoming more common. Another reason for this can be the realization of the benefits of these tools and methods by project participants in facilitating the collaboration efforts among the team members. The architect-of-record for this project, who also had an experience on working on four previous projects of FIU acknowledged that higher level ICT tools and methods in the recent projects are resulting in improving the overall project delivery effectiveness. 
Table 6.14: IPD Readiness Score- Case F

\begin{tabular}{|c|c|c|c|}
\hline Principle & Score & Source & Remarks \\
\hline EIKP & 5 & $\begin{array}{l}\text { - Interview with FIU's Project Manager } \\
\text { for Case F Project. } \\
\text { - Article } 3.3 \text { of agreement between owner } \\
\text { and A/E. } \\
\text { - Article } 8.1 .1 \text { of agreement between } \\
\text { owner and construction manager. }\end{array}$ & $\begin{array}{l}\text { - A/E was involved at programming } \\
\text { stage } \\
\text { - } \mathrm{CM} / \mathrm{GC} \text { was added on the project at SD } \\
\text { stage. } \\
\text { - Subcontractors were involved with } \mathrm{CM} \\
\text { to develop GMP. }\end{array}$ \\
\hline CDM & 2.5 & $\begin{array}{l}\text { - Interview with FIU's Project Manager } \\
\text { for Case F Project. } \\
\text { Article } 3 \text { of A/E and CM contracts with } \\
\text { owner. }\end{array}$ & $\begin{array}{l}\text { - } \mathrm{CM} / \mathrm{GC} \text { firm was responsible to making } \\
\text { recommendations. Final decision makers } \\
\text { were Owners or A/E on behalf of owner. }\end{array}$ \\
\hline ID & 7.5 & $\begin{array}{l}\text { - Interview with FIU's Project Manager } \\
\text { for Case F Project. }\end{array}$ & $\begin{array}{l}\text { Project team met every week for } \\
\text { scheduled meetings and need based } \\
\text { meetings were also called. }\end{array}$ \\
\hline JDPTC & 5 & $\begin{array}{l}\text { - Interview with FIU's Project Manager } \\
\text { for Case F Project. } \\
\text { - Interview with A/E for the project } \\
\text { - Programming Document }\end{array}$ & $\begin{array}{l}\text { - Program was developed by FIU based } \\
\text { on client's needs and available auxiliary } \\
\text { funds. A/E and CM provided external } \\
\text { validation to program. }\end{array}$ \\
\hline FT & 2.5 & $\begin{array}{l}\text { - Article } 12.5 \text { of the Owner }-\mathrm{A} / \mathrm{E} \\
\text { agreement. } \\
\text { - Article } 3.3 .12 \text { and } 3.3 .13 \text { of agreement } \\
\text { between owner and construction } \\
\text { manager. }\end{array}$ & $\begin{array}{l}\text { - All books were open by } \mathrm{A} / \mathrm{E} \text {, } \\
\text { consultants, contactors, subcontractors }\end{array}$ \\
\hline SRR & $\mathbf{0}$ & $\begin{array}{l}\text { - Interview with FIU's Project Manager } \\
\text { for Case F Project. }\end{array}$ & $\begin{array}{l}\text { All the savings were returned to the } \\
\text { owners }\end{array}$ \\
\hline LWKP & $\mathbf{0}$ & & No mutual liability waivers. \\
\hline MRT & 2.5 & $\begin{array}{l}\text { - Professional Qualifications Supplement } \\
\text { for A/E } \\
\text { - Construction Manager Qualifications } \\
\text { Supplement } \\
\text { - Interview with FIU's Project Manager } \\
\text { for Case F Project }\end{array}$ & $\begin{array}{l}\text { Its } \mathrm{A} / \mathrm{E} \text { 's fifth project with Owner. } \mathrm{A} / \mathrm{E} \\
\text { and } \mathrm{CM} \text { had past working experience }\end{array}$ \\
\hline WTC & 5 & $\begin{array}{l}\text { - Interview with FIU's Project Manager } \\
\text { and A/E. }\end{array}$ & $\begin{array}{l}\text { - Collaboration was facilitated by onsite } \\
\text { full time architect that helped CM work } \\
\text { through any issues. }\end{array}$ \\
\hline $\mathbf{O C}$ & 5 & $\begin{array}{l}\text { Interview with FIU's Project Manager } \\
\text { and A/E. }\end{array}$ & $\begin{array}{l}\text { - FIU and all other related participants } \\
\text { were copied on to the communication } \\
\text { between the } \mathrm{A} / \mathrm{E} \text { and } \mathrm{CM} \text {. }\end{array}$ \\
\hline Total & 35 & & \\
\hline
\end{tabular}


Table 6.15: Determination of ICT Level- Case- F

\begin{tabular}{|l|c|l|}
\hline Function & $\begin{array}{l}\text { ICT } \\
\text { Level }\end{array}$ & Remarks \\
\hline P1 & II & Manual development and qualitative selection \\
\hline P2 & I & Manual Estimating process \\
\hline P3 & I & Manual Scheduling process \\
\hline SD1 & III & Revit 3D for design, Newforma for sharing \\
\hline SD2 & I & Specifications without links to source data or design \\
\hline SD3 & I & Use of standalone spreadsheet tools. \\
\hline SD4 & III & Navisworks \\
\hline DD1 & III & Revit 3D \\
\hline DD2 & III & Navisworks \\
\hline DD3 & I & Primavera (P6) \\
\hline CD1 & III & Navisworks \\
\hline CD2 & III & Revit 3D \\
\hline CD3 & I & Specifications without links to source data or design \\
\hline CD4 & I & Primavera (P6) \\
\hline C1 & III & 1. Navisworks 2. Buzzsaw \\
\hline C2 & II & $\begin{array}{l}\text { Planning meetings utilize the electronic projection of the } \\
\text { scheduling software. }\end{array}$ \\
\hline C3 & I & CMiC (not shared) \\
\hline C4 & I & Manual Wet signed \\
\hline C5 & I & Manual copies of all records are maintained \\
\hline C6 & I & $\begin{array}{l}\text { Forecasting reports are manually generated based on progress } \\
\text { reports. }\end{array}$ \\
\hline
\end{tabular}

\subsubsection{IPD READINESS REPORT}

Table 6.20 demonstrates the IPD readiness report for case F. It can be observed that for majority of ICT push principles, there is a correlation between ICT levels and IPD readiness scores. The only exception to this rule is CDM where higher level ICT tools and methods remained underutilized due to low IPD readiness. This finding highlights an important fact that organizational barriers to IPD readiness can negatively influence the project and should be removed in order to take advantage from the advanced level ICT tools and methods. 
Table 6.20: IPD readiness Report - Case F

\begin{tabular}{|c|c|c|c|c|c|c|}
\hline & CDM $=2.5$ & JDPTC $=5$ & ID $=7.5$ & $\mathrm{OC}=5$ & WTC $=5$ & FT $=2.5$ \\
\hline PI & & II & & & I & \\
\hline $\mathrm{P} 2$ & & I & & & & \\
\hline P3 & & I & & & & \\
\hline SD1 & & III & III & & & \\
\hline SD2 & & I & $\mathrm{I}$ & & & \\
\hline SD3 & I & I & & & & \\
\hline SD4 & III & III & III & & & \\
\hline DD1 & & & III & III & III & \\
\hline DD2 & III & & III & III & & \\
\hline DD3 & I & & I & I & I & \\
\hline CD1 & III & & III & III & III & \\
\hline $\mathrm{CD} 2$ & & & III & & & \\
\hline CD3 & & & $\mathrm{I}$ & & & \\
\hline CD4 & $\mathrm{I}$ & & & I & I & \\
\hline $\mathrm{C} 1$ & III & & & III & III & \\
\hline $\mathrm{C} 2$ & II & & & II & II & \\
\hline $\mathrm{C} 3$ & I & & & I & I & \\
\hline $\mathrm{C} 4$ & & & & & & $\mathrm{I}$ \\
\hline $\mathrm{C} 5$ & $\mathrm{I}$ & & & & I & $\mathrm{I}$ \\
\hline C6 & $\mathrm{I}$ & & & $\mathrm{I}$ & $\mathrm{I}$ & \\
\hline
\end{tabular}

The application of IPD-RAM to the six selected case projects from FIU was demonstrated in section 6.3. While the results of individual applications reveal some case relevant findings and gaps, for drawing inferences that are more meaningful from the results of the application the following chapter compares all the cases.

\subsection{CHAPTER SUMMARY}

In this chapter, application of IPD-RAM on six case study projects is described in details. The application of the model resulted in three outcomes for each of the project i.e. IPD readiness scores, ICT levels at which each project function is carried out and the combined report of IPD readiness as cross-referenced by the level of ICT used. These results are further analyzed in Chapter 7 to determine the gaps in IPD readiness from which a set of ICT recommendations emerged. 


\section{CHAPTER-7: RESULTS AND ANALYSIS}

\subsection{INTRODUCTION}

The application of IPD-RAM is demonstrated in the previous chapter using six construction case projects. In this chapter, the results of application and analysis of the results are presented. Specific ICT recommendations for improving IPD readiness were derived from this analysis. First, the overall results of IPD readiness model application are discussed, and then an in-depth analysis of ICT push principles for gap identification is presented. Inferences made are based on the IPD readiness scores and the levels of ICT tools and methods for all project functions.

\subsection{IPD READINESS SCORES FOR CASE STUDY PROJECTS}

The results of the application of IPD-RAM are discussed in this section. The first outcome of application is the IPD readiness scores. The results of assessment for all the six case projects are presented in Table 7.1 below.

Table 7.16: IPD Readiness Scores of the Case Projects

\begin{tabular}{|l|c|c|c|c|c|c|}
\hline Principle & Case A & Case B & Case C & Case D & Case E & Case F \\
\hline EIKP & 5 & 2.5 & 5 & 5 & 5 & 5 \\
\hline CDM & 2.5 & 2.5 & 2.5 & 2.5 & 2.5 & 2.5 \\
\hline ID & 7.5 & 2.5 & 2.5 & 7.5 & 2.5 & 7.5 \\
\hline JDPTC & 2.5 & 2.5 & 2.5 & 2.5 & 2.5 & 5 \\
\hline FT & 2.5 & 2.5 & 2.5 & 2.5 & 2.5 & 2.5 \\
\hline SRR & 0 & 0 & 0 & 0 & 0 & 0 \\
\hline LWKP & 0 & 0 & 0 & 0 & 0 & 0 \\
\hline MRT & 2.5 & 0 & 2.5 & 2.5 & 2.5 & 2.5 \\
\hline WTC & 5 & 0 & 2.5 & 5 & 0 & 5 \\
\hline OC & 5 & 2.5 & 2.5 & 2.5 & 2.5 & 5 \\
\hline Total & $\mathbf{3 2 . 5}$ & $\mathbf{1 5}$ & $\mathbf{2 2 . 5}$ & $\mathbf{3 0}$ & $\mathbf{2 0}$ & $\mathbf{3 5}$ \\
\hline
\end{tabular}


It can be observed that the total IPD readiness scores for all the cases lies within the lower third range (maximum is 35 out of 100). The scores for recent project cases; A, $\mathrm{D}$ and $\mathrm{F}$ are found to be higher when compared to older cases $\mathrm{C}$ and $\mathrm{E}$. The only exception to this trend is case B that is a recently finished project but has scored low in IPD readiness.

Second result of application of the model is the assessed ICT levels for the project functions. The outcomes of this assessment are given in Table 7.2. It can be noticed that again for newer projects, cases A, D and E, the ICT levels for tools and methods utilized to perform several project functions are found to be higher as compared to cases $\mathrm{C}$ and $\mathrm{E}$, the older constructions.

Table 7.17: Project Functions' ICT Levels of the Case Projects

\begin{tabular}{|l|c|c|c|c|c|c|}
\hline & $\begin{array}{l}\text { Case } \\
\mathbf{A = 3 2 . 5}\end{array}$ & $\begin{array}{l}\text { Case } \\
\mathbf{B = 1 5}\end{array}$ & $\begin{array}{l}\text { Case } \\
\mathbf{C = 2 2 . 5}\end{array}$ & $\begin{array}{l}\text { Case } \\
\mathbf{D = 3 0}\end{array}$ & $\begin{array}{c}\text { Case } \\
\mathbf{E = 2 0}\end{array}$ & $\begin{array}{c}\text { Case } \\
\text { F=35 }\end{array}$ \\
\hline Functions & \multicolumn{7}{|c|}{ Level } \\
\hline P1 & I & I & I & I & I & II \\
\hline P2 & I & I & I & I & I & I \\
\hline P3 & I & I & I & I & I & I \\
\hline SD1 & III & I & I & III & I & III \\
\hline SD2 & I & I & I & I & I & I \\
\hline SD3 & I & I & I & I & I & I \\
\hline SD4 & III & I & I & III & II & III \\
\hline DD1 & III & I & I & III & I & III \\
\hline DD2 & III & I & I & III & II & III \\
\hline DD3 & I & I & I & I & I & I \\
\hline CD1 & III & I & I & III & I & III \\
\hline CD2 & III & I & I & III & I & III \\
\hline CD3 & I & I & I & I & I & I \\
\hline CD4 & I & I & I & II & I & I \\
\hline C1 & III & III & II & III & II & III \\
\hline C2 & II & II & I & II & I & II \\
\hline C3 & II & I & I & I & I & I \\
\hline C4 & I & I & I & I & I & I \\
\hline C5 & I & I & I & I & I & I \\
\hline C6 & II & I & I & I & I & I \\
\hline
\end{tabular}


As noted earlier, the only exception to common trend was found in case B, a recent project that utilized low ICT level tools and methods to perform most project functions. Only function $\mathrm{C}$, related to coordination of work with subcontractors, was observed to be using ICT at level III. The contractor developed a federated 'Navisworks' model for clash detection from the inputs of its subcontractors.

In the subsequent discussion, the relationship between IPD readiness and ICT levels is conferred.

The delivery method for all these cases remained essentially the same i.e. $C M$ at Risk, and business setup of the organization also did not vary much. The variations in IPD readiness scores can be attributed to the ways the project functions were performed. In newer projects, the functions were carried out in markedly different ways, utilizing significantly improved techniques and methods. One significant change observed was the advanced use of ICT tools and methods, as can be seen in Table 7.2. It is observed that the majority of functions in cases D and E were performed using lower level ICTs. Respective IPD readiness scores were also found to be lower in D and E, in comparison to $\mathrm{A}, \mathrm{D}$ and $\mathrm{F}$.

Case B is the only exception among the recently completed projects for which both the IPD readiness score and the ICT levels at which several project functions were carried out were low. The lower IPD readiness score in this case can be partly associated with comparatively late involvement of the contractor in the project, and other organizational aspects such as lack of the organizations' previous working experience as a team. Most of the project functions for this case were found to be performed at level I ICT. The low-level use of ICT tools and methods did not facilitate IPD readiness. One 
can conclude from the findings of case B that the difference in IPD readiness between the recent and older projects is associated with the use of relatively higher (advanced and sophisticated) level ICT tools and methods.

Before discussing, the 'ICT push' effect in detail, the impacts of four predominantly 'IPD pull' principles on the overall IPD readiness are discussed in the following.

\subsubsection{EFFECTS OF EIKP ON IPD READINESS}

Early involvement of key participants is one of the most influential IPD principles and has potential to impact the overall IPD readiness of the project. It is because early involvement facilitates collaboration and integration of the project team.

As all six projects were delivered through $\mathrm{CM}$ at Risk delivery method it allowed the involvement of contractor (as $\mathrm{CM} / \mathrm{GC}$ ) early in the project during the design phase. Therefore, the resulting IPD readiness score for EIKP remained in the middle of the range for most of the cases. The only exclusion is case B where the IPD readiness score for EIKP is low because this project was initially planned to be delivered through designbid-build delivery method. The owner changed the delivery method to CM at Risk during the design phase of the project and CM was included in the later stage of the detailed development phase of the project. If the total IPD readiness score of this project (case B) is compared with other projects it can be observed that there is a significant difference. This is logical as early involvement of key participants affects many other principles like ID and JDPTC which are dependent on early contributions of contractors and sub contractors in the programming and early design phases. 
By analyzing, the EIKP score of the study organization across all six projects one single recommendation can be made. It is -involve subcontractors early in the project to further improve the IPD readiness related to EIKP. Current procurement laws for public projects do not generally allow the early involvement of sub-contractors. However, interviews with the contractors revealed that informal inclusion of sub-contractors is possible. The interviews also disclosed that subcontractors are usually involved with the contractors during the construction documentation phase of the project to help setting up the GMP. The involvement is voluntary based only with the incentive that better understanding of the design might help them (the subcontractors) prepare their bids more competitively.

\subsubsection{EFFECTS OF LWKP ON IPD READINESS}

It can be observed that the two contractual IPD principles, LWKP and SRR were not implemented at all in any of the six case projects. For LWKP, it is quite understandable, as most public owners do not have the authority to exercise complete liability waivers in their projects. However, state statutes and regulations vary widely on limiting some liabilities such as consequential damages. For example, previously published case study for a public project of City of Phoenix indicated that standard contract of this agency does allow limitation of consequential damages (AIA 2012). On the other hand, study of Florida statutes revealed that the State does not currently allow any limitation on such damages.

Thus, it can be said that the IPD readiness in this area cannot be improved unless changes are made to hold liability waivers in the prevailing public procurement laws. 


\subsubsection{EFFECTS OF SRR ON IPD READINESS}

Similarly, SRR is a contractual principle that in general, requires modification in public procurement laws in order to be implemented in public projects. It is noted that from the literature search that if shared risks is possible to some extent, shared reward is considered a taboo in public organizations. Owner's opinion about the benefit sharing incentive sharing has to be built before expecting it to be common.

Through alternative delivery methods like CM at Risk an owner can benefited by the alignment of participants interest to some extent by sharing incentives within the team. An example of this incentive sharing observed in Edith Green Wendell Wyatt Federal Building project where General Services Administration (GSA) went into an arrangement with the contractor to share incentives for completing the construction under the target cost. The sharing of incentives with the contractor resulted in better alignment of the interests. Positive experience with such a setup also led the owners representative to remark that it would been even more beneficial if the architect of the project would also be the part of incentive sharing team (AIA 2012).

SRR was not exercised on any of the case study projects. When the matter was further investigated with the focus group members, their immediate reply was that the organization was not authorized to share rewards (incentives). However, they were unsure about the exact statute prohibiting them from sharing rewards or offering incentives for better performance or for saving time and money. Further investigation of state statutes and regulations about the possibility of incentive sharing within public projects of Florida did not result in any substantive evidence for or against it. However, Florida's Collier County Public Utilities Division (Emerson 2006) which indicates that 
the public project in Florida can utilize incentive sharing to some extent found an example of incentive sharing in water reclamation facility expansion project. Thus, it is suggested to exercise performance based incentive sharing for the organization. NASFA et al. (2010) also recommends offering of performance based incentives to project participants for the owners seeking alternative project delivery and adopting IPD as a philosophy.

\subsubsection{EFFECTS OF MRT ON IPD READINESS}

The scores for MRT in all cases, except for case B, were set at 2.5 on the scale from zero to 10. It is on the low side indicating that 'mutual respect and trust' was not given much importance during the selection of project team and neither trust building attempts were made during the project. The past working experience among the project participants as a team was the only dimension of MRT that contributed to the resulting scores. In the above mentioned five cases, where there was low score (2.5) for MRT, the team had moderate amount of past working experience (as explained in table 5.11). In case $\mathrm{B}$ there was no evidence of past working experience between any of the organizations, thus the score for MRT was set at zero.

The overall IPD readiness score and the level of ICTs for each of the six cases are discussed above. It was observed that although the ICT levels are not considered while setting the IPD readiness scores, the two measures showed correlation. IPD readiness scores of the projects utilizing higher levels of ICT for performing different project functions were found to be consistently higher than the projects in which functions were carried out using ICT tools or methods at lower levels. This correlation confirms that the 
premise of this research study is correct and IPD readiness can be improved by the use of higher level ICT tools and methods to perform several project functions.

In the following section, an analysis of the findings for the six IPD principles that are considered as 'ICT push' principles is provided.

\subsection{EFFECT OF ICT PUSH ON IPD PRINCIPLES}

In this section, each of the six project cases are analyzed for the effects of ICT levels on IPD readiness. According to the push/pull classification (introduced in Section 5.5) six principles, namely, collaborative decision making and control (CDM), intensified design (ID), jointly developed project target criteria (JDPTC), fiscal transparency (FT), willingness to collaborate (WTC) and open communication (OC) are regarded as ICT push principles. All these principles are either collaborative or behavioral according to classification provided in Table 5.2. Thus these principles have a potential to be influenced by enhancing collaboration and communication among the project participants. Therefore, the levels of ICT tools or methods utilized to perform the functions associated with each of these principles would have impacts on IPD readiness. In the following subsections the effect of ICT levels on each of the six IPD principles, are discussed. Analyses are presented by comparing a pair of projects at a time. This made the determination of the effects of different ICT tools and methods on IPD readiness a relatively easy task. For this analysis, only the ICT push principles are considered, as the goal is to determine specific ICT enhancements that can be deployed to 'push' or improve IPD readiness. The first comparison is made between a recently finished project case $\mathrm{A}$, and a relatively older project case $\mathrm{C}$. 


\subsubsection{COMPARISON OF CASE A AND CASE C - INTENSIFIED DESIGN}

List of ICT tools and methods utilized to perform different functions associated with the 'Intensified Design' and IPD readiness scores (for ID) are represented in Table 7.3. The main functions for each of the design phases can be grouped into four sets i.e.; a. design development and sharing, b. design reviews, c. design specifications d. cost and schedule updates.

Table 7.18: Comparison of Cases A and C for ID

\begin{tabular}{|l|l|c|l|c|}
\hline & \multicolumn{2}{|c|}{ Case A } & \multicolumn{2}{c|}{ Case C } \\
\hline Functions & \multicolumn{1}{|c|}{ ID =7.5 } & III $=\mathbf{2 . 5}$ & AutoCAD - 2D & I \\
\hline SD1 & Revit 3D & & $\begin{array}{l}\text { Specifications without links to source } \\
\text { data or design }\end{array}$ & I \\
\hline SD2 & $\begin{array}{l}\text { Specifications without links to } \\
\text { source data or design }\end{array}$ & III & Paper-based Review & I \\
\hline SD4 & Navisworks & III & AutoCAD - 2D & I \\
\hline DD1 & Revit 3D & III & Paper-based Review & I \\
\hline DD2 & Navisworks & I & Primavera (P3) & I \\
\hline DD3 & Primavera (P6) & III & Paper-based Review & I \\
\hline CD1 & Navisworks & III & AutoCAD - 2D & I \\
\hline CD2 & Revit 3D & I & Primavera (P3) & I \\
\hline CD3 & Primavera (P6) & & & \\
\hline
\end{tabular}

It can be observed that in case A the ICT levels are higher than in case C. It is understandable because case A is recently finished project and the design; analysis and reviewing tools in recent years are much more advanced than common practicing tools and methods ten years ago. The higher IPD readiness can also be associated with the advanced ICT tools and methods for design and review related project functions, as these ICTs potentially increased the effectiveness of the performed functions. On the other hand, specifications and cost and schedule update related functions were performed at the same level with similar tools and methods. It shows that while design is taking advantage 
from higher-level ICT tools, other project functions (specifications, cost and schedule) estimates are not taking advantage from more recent or higher level ICTs.

Therefore, it can be assumed that the changes in IPD readiness scores are associated with the functions that are performed using ICTs at different levels in the two projects. The two functions performed using varying levels of ICTs in the two projects are compared below.

\section{a. Design Development}

- In case A, design (SD1, DD1 and CD2) was developed using Level III ICT (Revit 3D) while in case $\mathrm{C}$ utilized AutoCAD for developing 2D drawings at different design phases.

The scopes of BIM on case A were limited to architectural and structural design in Revit, energy analysis and envelop design. It was observed that the 3D model, using Revit, facilitated more effective communication of design intent among project participants and allowed quick changes in the design. It also facilitated rendering which made the design visualization closer to reality. It enabled the owner to select the design alternative based on better understanding of the end product. And swift design decisions were made possible for the project team. As compared to this, in case C, inconsistencies and mistakes were observed in several drawings and versions. It was because changes in one part of drawing were needed to be manually corrected in all drawings in which that part was used. Errors and omissions were frequently observed by the project participants between several sets of drawings issued. The relationship is explained in Figure 7.1 showing that the ICT push effect in case A resulted in increasing the participation of project team in design efforts and thus pushed IPD. Advanced tools utilized in case A 
facilitated the design process and allowed team members to meet more frequently (biweekly), whereas in case C both IPD readiness and ICT levels were low.

b. Design Reviews

- In case $\mathrm{A}, \mathrm{A} / \mathrm{E}$ and contractor utilized Navisworks for the Design reviews (SD4, DD2 and CD1) while case C, the 10 year old project, utilized conventional 2D CAD drawing and paper-based reviews for performing these same functions. Navisworks facilitated the design reviews by facilitating the project viewing among project participants and allowed real-time navigation in design. It also facilitated the photorealistic model rendering (as shown in Figure 7.2) that helped owners and their clients to better understand the design and review it during the design review presentations. In comparison to that design reviews in case $\mathrm{C}$ were mainly dependent on reviewing the complex $2 \mathrm{D}$ drawings. $\mathrm{A} / \mathrm{E}$ utilized sketches of design during presentations for design reviews, an example of which is shown in Figure 7.3. 
Following ICT pushes were produced by the use of 3D BIM in comparison to 2D CAD in case A; (1) Lesser errors and omissions in design (2) Better understanding of design intent among project participants (3) Swift design decisions based on better visualization of issues. The effects of improvements are also reflected in the IPD readiness scores for the two projects where in case A, higher participation of the project participants in frequent meetings (bi-weekly scheduled and need base meetings) at the design phase were facilitated by effective by utilizing the higher level ICTs. It can be assumed that case $\mathrm{C}$ score would have been closer to case A if higher level ICTs would have been utilized.

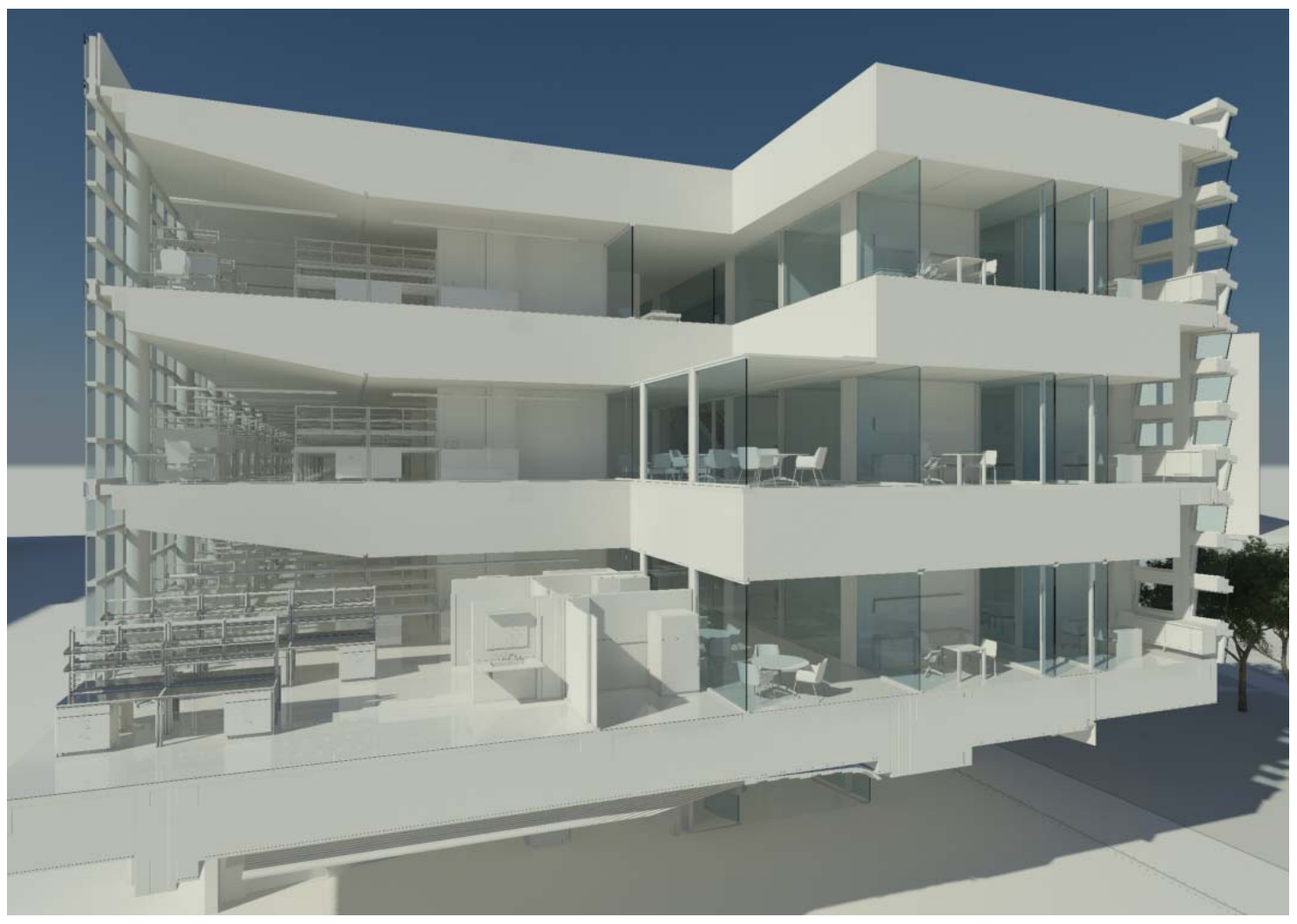

Figure 7.2: Example of Design Visualization in Case A

It should be noted that while BIM was utilized on case A for design development of design by $\mathrm{A} / \mathrm{E}$ and sharing it with the contractors and subcontractors, the owner (FIU) 
does not have BIM capabilities. The drawings in both cases were shared with owners as 2D representation of the design in portable document format (PDF). Although the owners benefited from the visualization and rendering of design during the project meetings and design review presentations, the IPD readiness would have been higher if the owners had BIM capabilities of their own. Thus for improving the IPD readiness in future projects, it is recommended to owner to invest in BIM to increase the internal capability of the organization.

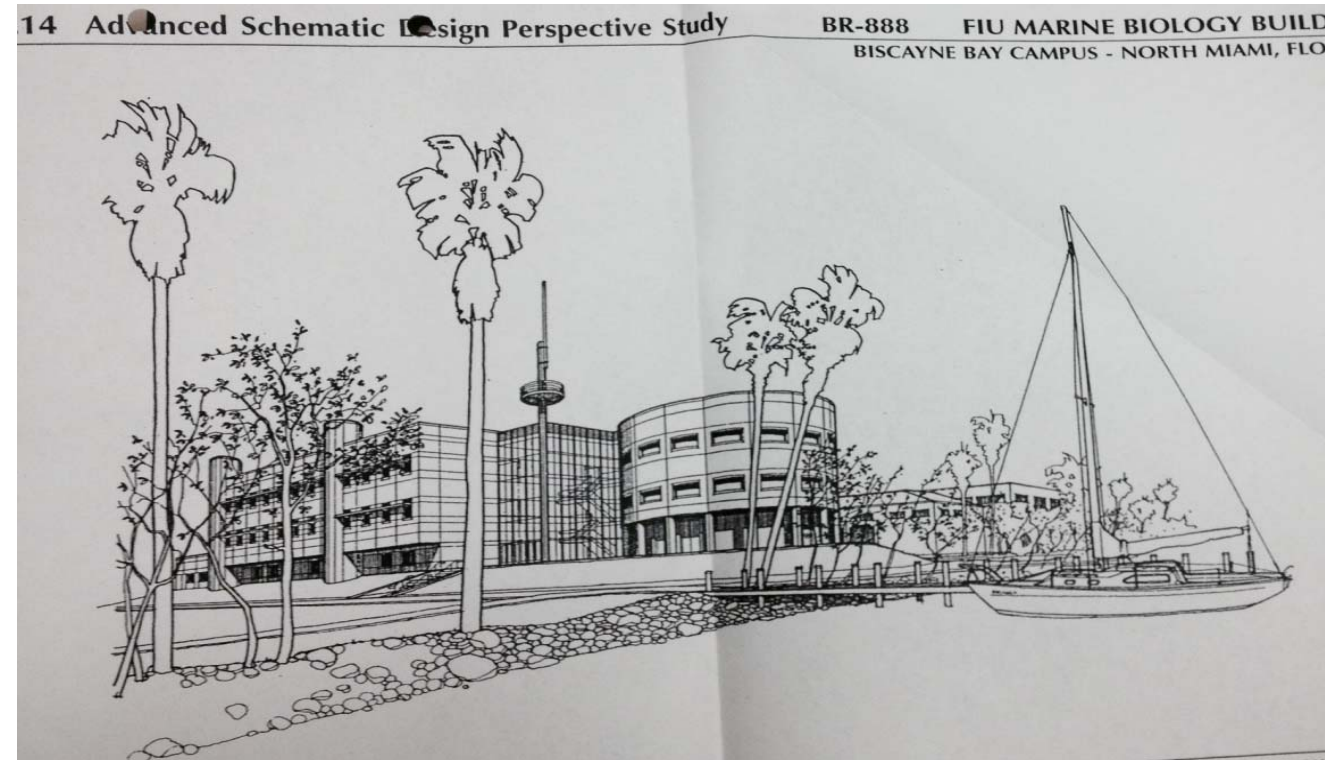

Figure 7.3: Example of Design Visualization in Case C

Next, the two recently finished projects, case B and case D are compared for the effects of ICT on the readiness related to willingness to collaborate.

\subsubsection{COMPARISON OF CASE B AND CASE D - WILLINGNESS TO} COLLABORATE

The two cases, B and D are recently finished projects. WTC related IPD readiness 
score for case B is assessed to be 0 (zero) and 5 for case D. Overall, case D has utilized ICT at higher levels as compared to case B. ICT levels for functions related to WTC are presented in Table 7.4.

Following discussion highlights, the differences in the two cases based on the different level ICTs utilized to perform several project functions.

- The design was developed and shared between the $\mathrm{A} / \mathrm{E}$ and contractor through BIM software, 3D Revit and Buzzsaw, in case D, while case B utilized AutoCAD for developing design that was shared as hardcopies of drawings as major deliverable at each phase of design.

- In Case D, use of 4Clicks software allowed the contractors to link the cost estimates with the latest R.S Means that resulted in developing more accurate estimates for the project. In case B Primavera (P3) was not linked with past data and estimates were manually updated.

- For design reviews, in case $\mathrm{B}$, the design was shared as 2D CAD with the project participants at the end of each design phase, therefore even though contractors who were BIM equipped were not able to review the design in 3D due to interoperability issue. Case D utilized Navisworks and Buzzsaw for design reviews and mark up.

- In both cases, the coordination with trades was performed at level III with the use of BIM for clash detection. However, the design and drawings in case $\mathrm{B}$ were not interoperable and additional efforts were made by the contractors to create their BIM models from 2D CAD. 
Table 7.19: Comparison of Cases B and D for WTC

\begin{tabular}{|c|c|c|c|c|}
\hline & \multicolumn{2}{|l|}{ CASE B } & \multicolumn{2}{|l|}{ CASE D } \\
\hline Functions & $\mathbf{W T C}=\mathbf{0}$ & & WTC $=5$ & \\
\hline DD1 & AutoCAD - 2D & I & Revit 3D & III \\
\hline DD3 & Primavera (P3) & $\mathbf{I}$ & $\begin{array}{l}\text { 4Clicks (software with } 2012 \text { R.S. } \\
\text { Means facilities cost data) }\end{array}$ & II \\
\hline CD1 & $\begin{array}{l}\text { Constructability reviews based on } \\
\text { CM's experience (no specific review } \\
\text { tools were utilized) }\end{array}$ & I & Navisworks & III \\
\hline CD4 & Paper-based Review & $\mathbf{I}$ & Buzzsaw & II \\
\hline C1 & Navisworks & III & 1. Navisworks 2. Buzzsaw & III \\
\hline $\mathbf{C 2}$ & $\begin{array}{l}\text { Electronic projection of the BIM } \\
\text { model }\end{array}$ & II & $\begin{array}{l}\text { Electronic projection of BIM } \\
\text { model }\end{array}$ & II \\
\hline $\mathbf{C 3}$ & OnTrac (not shared) & $\mathbf{I}$ & CMiC (not shared) & $\mathbf{I}$ \\
\hline $\mathbf{C 5}$ & Manual records & $\mathbf{I}$ & Manual records & $\mathbf{I}$ \\
\hline C6 & Primavera $(\mathrm{P} 3)$ & $\mathbf{I}$ & Primavera (P6) & $\mathbf{I}$ \\
\hline
\end{tabular}

The interoperability of Revit model in case D resulted in increasing willingness between the project participants by providing incentives to contractors and subcontractors in the form of reduced work efforts to develop the construction model and to perform clash detection. The contractor and subs to develop their respective models directly utilized the design model. The opportunities to facilitate such collaboration were lacking in case B.

In case $\mathrm{B}$, lack of willingness to collaborate was also evident through the project correspondence files. In this project, $\mathrm{A} / \mathrm{E}$ firm had expressed concerns about the transfer of electronic data file and its uses by the owner, the $\mathrm{CM}$ and the subcontractors. It developed an electronic data file agreement that addressed A/E's concerns about liabilities and proprietary issues and indemnified $\mathrm{A} / \mathrm{E}$ against any undetectable alterations made to the electronic files after being transferred. The CM signed the agreement. However, FIU refused to sign this agreement. This incident reflects the resistance of 
$\mathrm{A} / \mathrm{E}$ to collaborate and indicates the reasons for low score for WTC that is dependent upon the openness of interaction and alignment of interests of the project participants.

To further analyze the relationship between ICT levels and IPD readiness related to willingness to collaborate, older project case $\mathrm{C}$ is compared with the under construction project case $\mathrm{F}$.

Table 7.5: Comparison of Cases C and F for WTC

\begin{tabular}{|c|c|c|c|c|}
\hline & \multicolumn{2}{|l|}{ CASE C } & \multicolumn{2}{|l|}{ CASE F } \\
\hline Functions & \multicolumn{2}{|l|}{$\mathrm{WTC}=2.5$} & \multicolumn{2}{|l|}{$\mathbf{W T C}=5$} \\
\hline DD1 & 2D CAD & I & Revit 3D & III \\
\hline DD3 & Primavera (P3) & $\mathbf{I}$ & Primavera (P6) & $\mathbf{I}$ \\
\hline CD1 & 2D CAD drawings & $\mathbf{I}$ & Navisworks & III \\
\hline CD4 & Paper-based Review & I & Buzzsaw & III \\
\hline $\mathrm{C} 1$ & 2D CAD overlays & II & 1. Navisworks 2. Buzzsaw & III \\
\hline $\mathrm{C} 2$ & "Sticky note" on whiteboard & $\mathbf{I}$ & Electronic projection of BIM model & II \\
\hline $\mathrm{C} 3$ & Fax & I & CMiC (not shared) & $\mathbf{I}$ \\
\hline $\mathrm{C} 5$ & Manual records & I & Manual records & $\mathbf{I}$ \\
\hline C6 & Primavera (P3) & $\mathbf{I}$ & Primavera (P6) & I \\
\hline
\end{tabular}

It can be noted in Table 7.5 that IPD readiness score related to willingness to collaborate in case $\mathrm{F}$ is higher as compared to case $\mathrm{C}$. It is also correlated with higherlevel ICTs utilized in case F. The IPD readiness for case F could have been further improved if certain project functions performed at level I were performed using higher level ICTs. For example, the development and management of RFIs was performed using CMiC that was not shared. Sharing of the system would have increased the ICT method for project function C3 to level II and would have increased willingness to collaborate further by facilitating the interaction between project participants. The snapshot of the comparison of two cases for function $\mathrm{C} 3$ is presented in Figure 7.4. 
Figure 7.4: Case C, and F Comparisons for WTC Readiness and Level of ICT

\subsubsection{COMPARISON OF CASE A AND CASE D - OPEN COMMUNICATION}

In the following discussion, two recent projects are compared to analyze the effects of varying level ICT tools and methods on IPD readiness related to OC. As can be seen in Table 7.6, most of the project functions associated with OC are performed using similar level ICTs. However, there is still difference in the IPD readiness of the two cases. The different level ICTs are compared below to find out reasons for varying OC readiness.

- For case $\mathrm{A}$, the contractor shared their project management information system $(\mathrm{CMiC})$ with $\mathrm{A} / \mathrm{E}$, owner and subs to directly communicate RFIs. All related participants were copied on to the RFIs . While in case D the same system was only internally utilized by the contractor for generating RFIs 
- In case $\mathrm{A}$, the contractor utilized OurPlan, a digital planning and controlling tool with pull planning concept to manage the short interval planning. OurPlan allowed the construction team to track their success and failures and automatically generate a plan percent complete (PPC) reports. Where as in Case D the progress updates and forecasting were manually done using spreadsheets.

Table 7.6: Comparison of Cases A and D for OC

\begin{tabular}{|c|c|c|c|c|}
\hline & \multicolumn{2}{|l|}{ CASE A } & \multicolumn{2}{|l|}{ CASE D } \\
\hline Functions & $\mathrm{OC}=5$ & & $\mathrm{OC}=2.5$ & \\
\hline DD1 & Revit 3D & III & Revit 3D & III \\
\hline DD2 & Navisworks & III & Navisworks & III \\
\hline CD1 & Navisworks & III & Navisworks & III \\
\hline CD4 & Revit 3D & III & Revit 3D & III \\
\hline C1 & 1. Navisworks 2. Buzzsaw & III & 1. Navisworks 2. Buzzsaw & III \\
\hline C2 & $\begin{array}{l}\text { Electronic projection of the scheduling } \\
\text { software and BIM meetings during } \\
\text { project meetings. }\end{array}$ & II & $\begin{array}{l}\text { Planning meetings utilize the } \\
\text { electronic projections of BIM. }\end{array}$ & II \\
\hline C3 & $\begin{array}{l}\text { CMiC Project Management (shared with } \\
\mathrm{A} / \mathrm{E} \text {, Owners and Subs) }\end{array}$ & II & $\mathrm{CMiC}$ (for CM use only) & $\mathbf{I}$ \\
\hline C6 & $\begin{array}{l}\text { OurPlan (Digital planning and } \\
\text { controlling tool) }\end{array}$ & II & $\begin{array}{l}\text { Forecasting reports were } \\
\text { manually generated based on } \\
\text { progress reports }\end{array}$ & $\mathbf{I}$ \\
\hline
\end{tabular}

The sharing of the system in case A with project participants resulted in enhanced and open communication between the project participants by informally allowing all project participants to communicate with each other and therefore increasing the IPD readiness of the project. The snapshot of comparison of the two cases is presented in Figure 7.5. 
OurPlan allowed the construction team in case A to closely monitor their progress during project meetings and facilitated the development and communication of short term targets as compared to case $\mathrm{D}$ where these project reporting and forecasting process most mostly based on manual inputs to spreadsheet based tools.

Figure 7.5: Case A and D Comparisons for OC Readiness and Level of ICT

Another related observation in Project A, the owner's project manager was actively involved in all project communications. During the interview, he remarked, "The strength of the project team stems from a team approach and constant communication". This behavior was also observed in the project correspondence files that communication on this project that the team was communicating openly. As compared to case D, this was under another manager's responsibility. In an interview with the project manager it was revealed that the communication protocols were mostly followed as explicit in the contract. This means that for most of the project related issues 
$\mathrm{A} / \mathrm{E}$ team and Contractor team were in communication. FIU's representatives were cc'd only at some occasions of special concern. Overall, the owners' project manager was not part of conversations and RFIs.

\subsubsection{COMPARISON OF CASE E AND CASE F - FISCAL TRANSPARENCY}

Fiscal transparency can be explained as keeping the accounting books open and transparent to all project participants. The transparency of records is often associated with the development of trust between the project participants (AIA 2012). Table 7.7 shows the IPD readiness results for case $\mathrm{E}$ (older project) and case F (in construction) projects. It can be noted that;

- The scores for both projects remained the same despite the difference in time of their execution.

- Also no change is observed in the levels of ICT utilized for project functions that are associated with FT in the compared cases.

This indicates the practices of the organization with respect to fiscal transparency did not change with respect to time. While books are kept open in both cases (as required by Florida laws), the lower score is due to the limited electronic access of the records. This is partly due to the State requirements that mandate the contracts and other finances related documents to be wet signed only. Thus the current laws do not allow to achieve a level III ICT (to do e-business and maintain electronic records only) for functions $\mathrm{C} 4$ and C5 (purchase ordering and contract administration-record keeping). However, a level II ICT (combination of electronic and manual) can increase the level of transparency and access to records. Higher level of IPD readiness can be achieved by which the utilization 
of construction management information system that allow electronic records of invoices and payments made and record of contingencies available accessible to all project participants thus enhances the transparency of records.

Table 7.7: Comparison of Cases $\mathrm{E}$ and $\mathrm{F}$ for $\mathrm{FC}$

\begin{tabular}{|l|l|c|l|c|}
\hline & \multicolumn{1}{|c|}{ CASE E } & \multicolumn{2}{c|}{ CASE F } \\
\hline Functions & \multicolumn{1}{|c|}{ FT $=\mathbf{2 . 5}$} & \multicolumn{2}{c|}{ FT $=\mathbf{2 . 5}$} \\
\hline C4 & $\begin{array}{l}\text { Manual wet signed copies of } \\
\text { purchase orders }\end{array}$ & I & $\begin{array}{l}\text { Manual wet signed copies of } \\
\text { purchase orders }\end{array}$ & I \\
\hline C5 & $\begin{array}{l}\text { Manual copies of all contract } \\
\text { related records are maintained }\end{array}$ & I & $\begin{array}{l}\text { Manual copies of all contract } \\
\text { related records are maintained }\end{array}$ & I \\
\hline
\end{tabular}

\subsubsection{COMPARISON OF CASE B AND CASE F - COLLABORATIVE DECISION}

\section{MAKING}

The two recent cases $\mathrm{B}$ and $\mathrm{F}$ are compared to find out gaps in readiness related to

CDM. The comparison of functions related to CDM is presented in Table 7.8.

Table 7.8: Comparison of Cases B and F for CDM

\begin{tabular}{|c|c|c|c|c|}
\hline & \multicolumn{2}{|l|}{ CASE B } & \multicolumn{2}{|l|}{ Case F } \\
\hline Functions & \multicolumn{2}{|l|}{$\mathrm{CDM}=2.5$} & \multicolumn{2}{|l|}{$\mathrm{CDM}=2.5$} \\
\hline SD3 & Primavera (P3) & $\mathrm{I}$ & Primavera (P6) & I \\
\hline SD4 & 2D CAD (Paper-based Review) & I & Navisworks & III \\
\hline DD2 & 2D CAD (Paper-based Review) & I & Navisworks & III \\
\hline DD3 & Primavera $(\mathrm{P} 3)$ & I & Primavera $(\mathrm{P} 6)$ & $\mathrm{I}$ \\
\hline CD1 & $\begin{array}{l}\text { Constructability reviews based } \\
\text { on CM's experience (no specific } \\
\text { review tools were utilized) }\end{array}$ & I & Navisworks & III \\
\hline CD4 & 2D CAD (Paper-based Review) & $\mathrm{I}$ & Primavera (P6) & $\mathrm{I}$ \\
\hline $\mathrm{C} 1$ & Navisworks for clash detections & III & 1. Navisworks 2. Buzzsaw & III \\
\hline $\mathrm{C} 2$ & "Sticky note" on whiteboard & I & $\begin{array}{l}\text { Electronic projection of the } \\
\text { scheduling software and BIM } \\
\text { meetings during project meetings. }\end{array}$ & II \\
\hline $\mathrm{C} 3$ & OnTrac (not shared) & I & CMiC (not shared) & $\mathrm{I}$ \\
\hline $\mathrm{C} 5$ & $\begin{array}{l}\text { Manual copies of all records are } \\
\text { maintained }\end{array}$ & I & $\begin{array}{l}\text { Manual copies of all records are } \\
\text { maintained }\end{array}$ & $\mathrm{I}$ \\
\hline C6 & $\begin{array}{l}\text { Primavera }(\mathrm{P} 3)-\text { Manual } \\
\text { progress reporting and } \\
\text { forecasting }\end{array}$ & I & $\begin{array}{l}\text { Primavera (P6)-Manual progress } \\
\text { reporting and forecasting }\end{array}$ & $\mathrm{I}$ \\
\hline
\end{tabular}


It can be noticed that while many project functions in case $\mathrm{F}$ were performed utilizing higher level ICT tools and methods, the IPD readiness scores related to CDM for both cases remained the same as depicted in Figure 7.6.

Figure 7.6: Case B and F Comparisons for CDM Readiness and Level of ICT

Further investigation of the cases resulted in the finding that while advanced tools and methods were available the business set related to decision-making process remained the same in both cases. For design phase, related decisions the sole decision maker in both cases remained the $\mathrm{A} / \mathrm{Es}$ and contractors were responsible for the construction means and methods. This segregation in the decision making process did not allow the project participants of case F to fully utilize the higher-level ICT tools and methods available. It is an important identified gap and a barrier to improved IPD readiness of an organization and business setup. Business setup should be revised to allow better collaborative decisions between the project participants. 


\subsubsection{COMPARISON OF CASE E AND CASE F - JOINTLY DEVELOPED PROJECT TARGET CRITERIA}

The readiness related to JDPTC is compared for an older project case E and still under construction project case F. Table 7.9 compares the project functions for their corresponding ICT levels.

Table 7.9: Comparison of Cases E and F for JDPTC

\begin{tabular}{|l|l|c|l|c|}
\hline & \multicolumn{2}{|c|}{ CASE E } & \multicolumn{2}{c|}{ CASE F } \\
\hline Functions & \multicolumn{1}{|c|}{ JDPTC $=\mathbf{2 . 5}$} & I & SketchUp and Excel Spreadsheets & II \\
\hline P1 & Excel Spreadsheets & I & Excel Spreadsheets & I \\
\hline P2 & Excel Spreadsheets & I & Excel Spreadsheets & I \\
\hline P3 & Excel Spreadsheets & I & Revit 3D & III \\
\hline SD1 & 2D CAD & I & $\begin{array}{l}\text { Specifications without links to } \\
\text { source data or design }\end{array}$ & I \\
\hline SD2 & $\begin{array}{l}\text { Specifications without links } \\
\text { to source data or design }\end{array}$ & I & Primavera (P6) & I \\
\hline SD3 & Primavera (P3) & I & Navisworks & III \\
\hline SD4 & Paper-based Review & \multicolumn{2}{|l}{} \\
\hline
\end{tabular}

The IPD readiness scores related to JDPTC are dependent upon the participation of team members in setting up the project targets and the inputs provided by the team members. The higher JDPTC for case $\mathrm{F}$ is partly due to the early involvement of $\mathrm{A} / \mathrm{E}$ during the programming phase and contractor during the schematic design phase for case F. The level of ICT tools and methods utilized by the project team for case F were also find to be higher as compared to case E.

In Figure 7.7, the snapshot of the comparison of two cases is provided for project function P1 that was performed at two using two different level ICT tools and methods in the compared cases. The use of Revit in case $\mathrm{F}$ allowed the project participants to participate more frequently. Visualization of design made it possible for the users to give their input based on renderings of the model that were closer to real building and thus the selection of design, texture material were better incorporated in setting up the project 
targets. As compared to this case E did not benefit from such renderings. The relationship between ICT level and IPD readiness for the two compared cases for project function SD1 is presented in Figure 7.7. The figure is representing the push effect of higher level ICT tool in case F that resulted in improving the IPD readiness of the project.

Figure 7.7: Case E and F Comparisons for JDPTC Readiness and Level of ICT

Various comparisons between the cases discussed above resulted in identifying the gaps in readiness of the organization. Correlation was found between the IPD readiness and ICT levels at majority of instances that indicates the synergetic effect of ICT levels and IPD principles.

Project information related to basic performance indicators i.e. cost performance (original contracted cost and actual cost) and time performance (originally contracted duration and the actual duration) and also the communication performance indicator i.e. number of RFIs (Request for Information) and response times to RFIs were also collected for the case projects. The summary of collected information is presented in 
Table 7.10. It should be noted that case $F$ is an ongoing project and the actual performance of this project for several parameters is not available (shown as NA in the table).

Table 7.10: Performance Related Information for Cases

\begin{tabular}{|l|l|l|l|l|l|l|}
\hline Case & $\begin{array}{l}\text { Total } \\
\text { Number } \\
\text { of RFIS }\end{array}$ & $\begin{array}{l}\text { Total Number } \\
\text { of Change } \\
\text { Orders }\end{array}$ & $\begin{array}{l}\text { Original } \\
\text { Contracted } \\
\text { Cost } \\
\text { (\$millions) }\end{array}$ & $\begin{array}{l}\text { Final } \\
\text { (Actual) Cost } \\
\text { (\$millions) }\end{array}$ & $\begin{array}{l}\text { Original } \\
\text { Contracted } \\
\text { Duration }\end{array}$ & $\begin{array}{l}\text { Actual } \\
\text { Duration }\end{array}$ \\
\hline A & 658 & 39 & 42.86 & 40.50 & 547 & 547 \\
\hline B & 509 & 15 & 13.98 & 19.34 & 437 & 555 \\
\hline C & 326 & 11 & 10.19 & 10.69 & 425 & 733 \\
\hline D & 583 & 33 & 45.87 & 39.80 & 183 & 183 \\
\hline E & 251 & 53 & 11.15 & 15.76 & 693 & 1020 \\
\hline F & NA & NA & 27.00 & NA & 365 & NA \\
\hline
\end{tabular}

Note: NA - not available.

The total number of change orders $(\mathrm{CO})$ for each of the projects was also recorded and reported in Table 7.10. However, it was observed the total numbers of changes approved in a single change order varies widely. In some cases, single change order reflects changes in the contract due to single proposed change order (PCO). Other times a single change order may approve several PCOs (as high as 21 changes were observed to be approved in a single $\mathrm{CO}$ ). Thus, the number of change order does not reflect the true amount of changes made on the project. Therefore, it is not included in subsequent discussion.

Although there are several other factors that influence these performance indicators and the relationship between the performance indicators and IPD readiness is not straight forward, an attempt has been made in Table 7.11 to compare of the actual performance of the projects with respect to the above mentioned performance indicators and relate it with the IPD readiness. In the following discussion, the trend of performance will be analyzed. 
Table 7.11: Comparison of Cases for Performance Indicators

\begin{tabular}{|l|l|l|l|l|l|l|}
\hline Case & $\begin{array}{l}\text { IPD } \\
\text { Readiness } \\
\text { Score }\end{array}$ & $\begin{array}{l}\text { ICT Levels } \\
\text { (I), (II), (III) }\end{array}$ & $\begin{array}{l}\text { Number of } \\
\text { RFIS } \\
\text { (No./Sm) }\end{array}$ & $\begin{array}{l}\text { Response } \\
\text { Time of } \\
\text { RFIs } \\
\text { (days) }\end{array}$ & $\begin{array}{l}\text { Cost } \\
\text { Variation } \\
\text { (Actual } \\
\text { /contracted } \\
\text { cost) }\end{array}$ & $\begin{array}{l}\text { Schedule } \\
\text { Variation } \\
\text { (Actual } \\
\text { /contracted } \\
\text { duration) }\end{array}$ \\
\hline A & 32.5 & $10,3,7$ & 16.24 & 16 & 0.94 & 1 \\
\hline B & 15 & $19,0,1$ & 26.31 & 11.53 & 1.38 & 1.27 \\
\hline C & 22.5 & $19,0,1$ & 30.75 & 19.23 & 1.05 & 1.72 \\
\hline D & 30 & $10,3,7$ & 14.64 & 15.5 & 0.87 & 1 \\
\hline E & 20 & $17,3,0$ & 22.8 & 29.78 & 1.41 & 1.47 \\
\hline F & 35 & $11,2,7$ & NA & NA & NA & NA \\
\hline
\end{tabular}

Note: NA- not available.

To make the project parameters comparable to each other certain criteria are utilized. For instance to normalize the RFI value and make it comparable to other projects based on the sizes, the number of RFI is divided by the project construction cost. RFI response time is calculated as a mean value of difference between the date RFI was created and date it was responded.

To see the cost performance, cost variation is calculated which is basically a ratio of actual cost to the initial contracted sum. Cost Variation value less than $1(<1)$ means that the project completed at the cost less than the originally contracted and $>1$ represents cost overruns. Similarly, schedule variation defines the ratio of actual to planned (contracted) duration and originally contracted durations.

It can be noted that the two recently finished projects case $A$ and $D$ have performed better than the rest of the projects. The IPD readiness and ICT levels of these projects are higher than the rest of the projects and it is reflected back in the performance indicators i.e. number of RFIs per million dollars, cost variation and schedule variation. Both projects met there project targets related to duration and cost targets and resulted in savings for the owners. 
In the comparison of open communication above in section 7.3.3 these two projects were compared, it was found that case A score higher for IPD readiness related to $\mathrm{OC}$ and also the ICT level for performing project function C3 (development and management of RFIs). However, in the comparison of performance index, the case D

performed better than case A. When this finding was further investigated through interviews with the project participants, the project manager for case A responded "Often responses are provided verbally and are not formally closed out by the design team for some time. While this isn't typically the best practice, when you have a collaborative team that works together and can trust one another the team can work together efficiently to reach the end goal and schedule dates".

As compared to this, the projects with lower IPD readiness and level of ICT tools and methods, the performance trends are also mostly showing lower performance. Therefore, it can be said that broadly correlation was found between IPD readiness and project performance. However to say it with more confidence, rigorous analysis of the data is required which is out of scope of this research and might be perused as a future research area.

In the following section, the best and worst case based on IPD readiness score are compared to find out gaps in IPD readiness.

\subsection{COMPARISON OF ICTS BETWEEN CASE B AND CASE F}

To further analyze the relationship between ICT levels and IPD readiness and identify the gaps in IPD readiness, the worst and best case i.e. case B and case F are compared. It should be noted that the contractual arrangement and the business setup in 
both cases essentially remained the same, the difference in IPD readiness can be attributed to the different levels ICT tools and methods that are utilized to perform several project functions. Table 7.12 presents the comparison of functions between the two projects that were performed using different level ICT. The last column of the table is presenting the difference in IPD readiness of the two projects.

Table 7.12: Comparison of Cases B and F

\begin{tabular}{|c|c|c|c|c|c|}
\hline Functions & $\begin{array}{l}\text { ICT } \\
\text { Level }\end{array}$ & ICT tools /methods used & $\begin{array}{l}\text { ICT } \\
\text { Level }\end{array}$ & ICT tools/methods used & $\begin{array}{l}\text { IPD } \\
\text { Readiness } \\
\text { Improved }\end{array}$ \\
\hline & \multicolumn{2}{|c|}{ Case B } & \multicolumn{2}{|c|}{ Case F } & \\
\hline $\mathrm{P} 1$ & I & $\begin{array}{l}\text { Manual development and } \\
\text { qualitative selection }\end{array}$ & II & $\begin{array}{l}\text { SketchUp and Excel } \\
\text { Spreadsheets }\end{array}$ & JDPTC (2.5) \\
\hline SD1 & I & 2D CAD & III & $\begin{array}{l}\text { Revit 3D for design, } \\
\text { Newforma for sharing }\end{array}$ & $\begin{array}{l}\operatorname{ID(5),} \\
\operatorname{JDPTC}(2.5)\end{array}$ \\
\hline SD4 & I & Paper-based Review & III & Navisworks & $\begin{array}{l}\operatorname{ID(5),} \\
\operatorname{JDPTC}(2.5)\end{array}$ \\
\hline DD1 & I & 2D CAD & III & Revit 3D & $\begin{array}{l}\text { ID (5), OC } \\
(2.5), \text { WTC (5) }\end{array}$ \\
\hline DD2 & I & Paper-based Review & III & Navisworks & $\begin{array}{l}\text { ID (5), OC } \\
(2.5), \text { WTC (5) }\end{array}$ \\
\hline CD1 & I & $\begin{array}{l}\text { Experienced based } \\
\text { constructability review }\end{array}$ & III & Navisworks & $\begin{array}{l}\text { ID (5), OC } \\
(2.5), \text { WTC (5) }\end{array}$ \\
\hline $\mathrm{CD} 2$ & I & 2D CAD & III & Revit 3D & ID (5) \\
\hline $\mathrm{C} 2$ & I & $\begin{array}{l}\text { Planning meetings utilize } \\
\text { conventional "sticky note" } \\
\text { on whiteboard method. }\end{array}$ & II & $\begin{array}{l}\text { Planning meetings utilize } \\
\text { the electronic projection of } \\
\text { the scheduling software. }\end{array}$ & $\begin{array}{l}\text { WTC (5), OC } \\
(2.5)\end{array}$ \\
\hline
\end{tabular}

It can be said that while other factors are contact, the IPD readiness of case B would have improve by the magnitude represented in the last column if similar level ICT tools have been utilized on this project as of case F. For example, the IPD readiness 
related to JDPTC for case B would have improved by 2.5 if project function P1, SD1 and SD4 would have been performed using ICT tools and methods similar to case F.

This comparison is also beneficial for the owner organization to make future ICT investments as it represents the required level of ICTs to achieve certain IPD improvements. In addition, it can help in prioritizing the ICT tools based on the impact of the tool on several ICT push principles.

Although the above comparison provided the gap identification, it is not comprehensive. As even the best case studied, (case F) scored low in IPD readiness. To further strengthen the gap analysis, the following section will compare case $\mathrm{F}$ with a hypothetical case $\beta$.

\subsection{IPD READINESS SCORES FOR HYPOTHETICAL CASE $\beta$}

A hypothetical case $\beta$ is developed making assumptions that are based on the best possible IPD readiness scores that are generally possible with in the public sector organizations like the organization studied without changing the procurement laws. Also the level of ICTs are defined based on same assumption that are practical under prevailing regulations and does not necessarily are level III for all project functions. Table 7.13 depicts the assumptions made for assigning the IPD readiness scores for each of the ten IPD principles. The total IPD score for the hypothetical case $\beta$ (70) is considerably high as compared to the real cases where even the maximum score was only 35. The IPD readiness score for the ICT push principles is 50 . The major assumptions that are made to form the hypothetical score basically indicates the potential readiness levels that a public project can achieve in a setup where the project team is informally 
committed to deliver a project using IPD-like characteristics. It can be noted that the scores for two contractual related principles are still fairly low (2.5) indicating that less can be done to improve the IPD readiness for these principles without changing the procurement laws and regulations that governs the public projects. The considerably higher scores for the three behavioral principles are based on the assumption that behavioral principles can be implemented fairly easily if the project team is committed to collaboration.

Table 7.13: IPD Readiness Score for Hypothetical Case $\beta$

\begin{tabular}{|l|l|l|}
\hline IPD Principles & Score & Assumptions \\
\hline EIKP & 7.5 & $\begin{array}{l}\text { A/E and CM are involved at programming stage. Subs } \\
\text { involved with CM during CD Phase (Although majority of } \\
\text { participants are present at programming phase, late inclusion } \\
\text { of subs is accounted by giving the next best possible score) }\end{array}$ \\
\hline CDM & 7.5 & $\begin{array}{l}\text { All key participants provide input while final decision } \\
\text { makers are Owners, A/E, and Contractor }\end{array}$ \\
\hline ID & 10 & $\begin{array}{l}\text { When key participants are involved in design from the SD } \\
\text { phase and meet regularly }\end{array}$ \\
\hline JDPTC & 7.5 & $\begin{array}{l}\text { All key participants provide input while final project target } \\
\text { criteria are developed by Owners, A/E, and Contractor }\end{array}$ \\
\hline FT & 7.5 & $\begin{array}{l}\text { Open books are maintained by all project participants } \\
\text { excluding owners and all project participants have access to } \\
\text { records }\end{array}$ \\
\hline LWKP & 2.5 & $\begin{array}{l}\text { Limiting of consequential damages to the predetermined } \\
\text { amount between Owner and A/E or Contractor. }\end{array}$ \\
\hline SRR & 2.5 & $\begin{array}{l}\text { Only Contractor sharing risks and rewards against cost and } \\
\text { non cost targets }\end{array}$ \\
\hline MRT & 7.5 & $\begin{array}{l}\text { Trust-building workshops were conducted during the project } \\
\text { phases, team has medium prior working experience and trust } \\
\text { competence wasn't considered as selection criteria }\end{array}$ \\
\hline Total IPD Readiness \\
Score & 7.5 & $\begin{array}{l}\text { Goals are aligned but interaction between the participants is } \\
\text { partially open }\end{array}$ \\
\hline OC & 10 & $\begin{array}{l}\text { Communication flow is formally open and direct, frequency } \\
\text { of meetings is high }\end{array}$ \\
\hline
\end{tabular}


Similarly, the levels of ICTs assumed for the hypothetical case $\beta$ are presented in Table 7.14. As mentioned before, not all the ICT levels are at level III. It is because, for certain functions, for example contract administration-record keeping (C5) level III which suggest the entire record keeping is maintained electronically is not generally permissible in a public project. As wet-sign, documents are still mandated by the state or federal regulations. In such a case, level II (which is a combination of hardcopies and electronic documents) is a more realistic option.

Table 7.14: ICT Levels- Case $\beta$

\begin{tabular}{|l|c|l|}
\hline Function & $\begin{array}{l}\text { ICT } \\
\text { Level }\end{array}$ & Remarks \\
\hline P1 & III & Revit (LOD 100) \\
\hline P2 & III & Vico Cost Planner \\
\hline P3 & III & Vico Schedule Planner \\
\hline SD1 & III & Revit 3D \\
\hline SD2 & III & e-SPECS \\
\hline SD3 & III & Vico Office (5D BIM based workflow) \\
\hline SD4 & III & Navisworks \\
\hline DD1 & III & Revit 3D \\
\hline DD2 & III & Navisworks \\
\hline DD3 & III & Vico Office (5D BIM based workflow) \\
\hline CD1 & III & Navisworks \\
\hline CD2 & III & Revit 3D \\
\hline CD3 & III & e-SPECS \\
\hline CD4 & III & Vico Office (5D BIM based workflow) \\
\hline C1 & III & 1. Navisworks 2. Buzzsaw \\
\hline C2 & II & $\begin{array}{l}\text { Planning meetings utilize the electronic projection of the scheduling } \\
\text { software and BIM model }\end{array}$ \\
\hline C3 & II & CMiC Communication (shared) \\
\hline C4 & II & CMiC Open Enterprise v10 \\
\hline C5 & II & CMiC Open Enterprise v10 \\
\hline C6 & II & OurPlan (Digital planning and controlling tool) \\
\hline
\end{tabular}

This hypothetical case $\beta$ will serve as the target IPD readiness for the study organization for its future projects. The comparison is made between this hypothetical case $\beta$ and best case for FIU, case and is discussed in the following section. 


\subsubsection{COMPARISON OF CASE F AND CASE $\beta$}

The project functions performed with different level ICT tools and methods utilized in actual case project $\mathrm{F}$ and hypothetical case $\beta$ are shown in Table 7.15.

Table 7.15: Comparison of Cases F and $\beta$

\begin{tabular}{|c|c|c|c|c|c|}
\hline $\begin{array}{l}\text { Project } \\
\text { Functions }\end{array}$ & $\begin{array}{l}\text { ICT } \\
\text { Level }\end{array}$ & ICT tools/methods used & $\begin{array}{l}\text { ICT } \\
\text { Level }\end{array}$ & $\begin{array}{l}\text { ICT tools/methods } \\
\text { recommended }\end{array}$ & $\begin{array}{l}\text { IPD } \\
\text { Principles } \\
\text { (Potential } \\
\text { Increase in } \\
\text { score) }\end{array}$ \\
\hline & \multicolumn{2}{|c|}{ Case F } & \multicolumn{2}{|c|}{ Case $\beta$} & \\
\hline $\mathrm{P} 1$ & II & $\begin{array}{l}\text { SketchUp and Excel } \\
\text { Spreadsheets }\end{array}$ & III & Revit (LOD 100) & JDPTC (2.5) \\
\hline $\mathrm{P} 2$ & I & Manual Estimating process & III & Vico Cost Planner & JDPTC (2.5) \\
\hline P3 & I & Manual Scheduling process & III & Vico Schedule Planner & JDPTC (2.5) \\
\hline SD2 & I & $\begin{array}{l}\text { Specifications without links } \\
\text { to source data or design }\end{array}$ & III & e-SPECS for Revit & $\operatorname{ID}(2.5)$ \\
\hline SD3 & I & $\begin{array}{l}\text { Use of standalone } \\
\text { spreadsheet tools. }\end{array}$ & III & $\begin{array}{l}\text { Vico Office (5D BIM based } \\
\text { workflow) }\end{array}$ & $\begin{array}{l}\text { CDM (5), ID } \\
(2.5), \\
\text { JDPTC (2.5) }\end{array}$ \\
\hline DD3 & I & Primavera (P6) & III & $\begin{array}{l}\text { Vico Office (5D BIM based } \\
\text { workflow) }\end{array}$ & $\begin{array}{l}\text { CDM (5), ID } \\
(2.5), \\
\text { JDPTC (2.5) }\end{array}$ \\
\hline CD3 & I & $\begin{array}{l}\text { Specifications without links } \\
\text { to source data or design }\end{array}$ & III & e-SPECS for Revit & $\operatorname{ID}(2.5)$ \\
\hline $\mathrm{CD} 4$ & I & Primavera (P6) & III & $\begin{array}{l}\text { Vico-5D BIM based } \\
\text { workflow }\end{array}$ & $\begin{array}{l}\text { ID(2.5), } \\
\text { CDM(5), } \\
\text { WTC (2.5) }\end{array}$ \\
\hline $\mathrm{C} 3$ & I & $\begin{array}{l}\text { CMiC Communication (not } \\
\text { shared) }\end{array}$ & II & $\begin{array}{l}\text { CMiC } \\
\text { Communication(shared) }\end{array}$ & $\begin{array}{l}\text { OC(5), } \\
\text { WTC(2.5) }\end{array}$ \\
\hline $\mathrm{C} 4$ & I & Manual Wet signed & II & CMiC Open Enterprise v10 & $\mathrm{FT}(5)$ \\
\hline $\mathrm{C} 5$ & I & $\begin{array}{l}\text { Manual copies of all records } \\
\text { are maintained }\end{array}$ & II & CMiC Open Enterprise v10 & $\mathrm{FT}(5)$ \\
\hline
\end{tabular}


The level of ICT tools and methods in case $\beta$ creates the push effect for the IPD principles and increases the IPD readiness of the case. It can be assumed that if case F would have utilized the similar ICT tools and methods its IPD readiness would have improved by the magnitude provided in the last column. For example the development of conceptual BIM model at programming stage and linking the cost and schedule with the model to develop and analyze several project concept scenarios could have resulted in potentially increasing the IPD readiness of case F to 7.5 from the existing score of 5 . The potential difference is indicated in the parenthesis in the last column. Similarly, the potential improvements in all six IPD principles are presented in the table.

This analysis is particularly beneficial for making recommendations related to ICT based improvements for the studied organization. These recommendations are discussed in detail in chapter 8 . Before that, following discussion highlights the validation of the application of IPD-RAM in next section.

\subsection{VALIDATION OF MODEL APPLICATION}

To validate the application of the model, results and analysis of case studies were presented to a focus group member. The member is the Director of Construction Facilities, FIU.

For collecting the feedback, the model was first presented to a focus group member. Next, the results of application of the model to analyze the IPD readiness case projects and gap identification were shared. Based on these results, the proposed improvement strategies were discussed with the group member. The feedback on the 
applicability of the model and the proposed improvement strategies ware recorded. Following discussion summarizes the feedback.

Regarding the IPD principle CDM, the analysis indicates that the current decision making structure does not fully allow participation of contractors and subcontractors in the decisions. The member agreed to the finding that the decision making structure of the organization is hierarchical and impedes the full utilization construction expertise of ICT tools for preconstruction phases of the project. It was agreed that a involvement of the contractors and subcontractors in a decision making group can be beneficial. However, such change will be challenging to implement as it will require to change the long tested decision making structure.

It was established that the use of higher-level ICT tools and methods in the design process can improve the IPD readiness. It was mentioned that the organization is realizing the benefits of BIM for design process and the latest contracts between FIU and A/Es are asking for BIM as design deliverable. However, currently FIU does not have BIM capability, which causes the interoperability issues. FIU is currently in process of finding out the technological, organizational and investment requirement of BIM. The plans are also to benefit from BIM for facilities management.

At programming phase, the in-house expertise is mostly utilized by FIU to develop the project preliminary concepts, cost and time estimates. The use of ICT at this stage for all phases was found to be limited to level I ICT tools that do not facilitate improvement in IPD readiness. The member agreed that theoretically, the utilization of decision support tools and use of BIM can lead to better and more accurate project target criteria. 
Related to improvement in fiscal transparency, it was mentioned that record keeping in hardcopies is required by Florida Statues. On the question related to electronic record keeping that would allow the access of financial record to owners, it was remarked by one of the members "organizationally, we are not ready for such a change". It would require a buy-in from all the project managers. It was mentioned that organization attempted to move to centralized project management system in the past (15-20 years ago) that was not successful.

The analysis of results that highlighted that the IPD readiness scores between the case projects differ with the utilization of higher level ICTs on the projects were shared with the member. The member agreed that the variation in score can be partly attributed to the level of ICTs. However, it was added that the "chemistry between the project team" is also very important factor effecting the team's collaboration.

The specific findings from the analysis of two case studies that the projects where the stringent communications protocols and strict lines of communication were not followed the IPD readiness score for open communication were higher. As observed in case A, Contractor shared their project management system (CMiC) with the owners, $\mathrm{A} / \mathrm{Es}$ and subcontractors. This sharing of the system improved the level of communication between the project participants and for this project, the lines of communication were blurred. As compared to another project case D where the $\mathrm{CM} / \mathrm{GC}$ utilized the same system but did not share it with other participants. The sharing of the system resulted in more open communication between the case A participants. The director of construction facilities responded to this observation affirmatively and remarked that there is no doubt that the shared $\mathrm{CMiC}$ led to communication that is more 
open. However also expressed the liability concerns that can result in the crossing the lines of communication.

From the above discussion, it can be concluded that the responses of the focus group member were generally in agreement with the findings that were obtained through the application of IPD-RAM. Therefore it can be said that the model is capable of capturing the IPD readiness of the projects based on the developed scoring scales of IPD readiness. The focus group member also appreciated the improvement strategies. However, in many instances, the organizational and legal constraints in implementing the strategies were also identified in the feedback.

\subsection{CHAPTER SUMMARY}

The gaps or differences in IPD readiness between the case study projects were identified and analyzed in this chapter. In general, all these cases depict low IPD readiness. In-depth analysis of ICT push principles resulted in identification of several opportunities in ICT implementation (in terms of levels) and organizational setup. In the next chapter, specific ICT recommendations for the organization are provided in the form of strategic decision that if implemented have the potential to improve IPD readiness of the organization. 


\section{CHAPTER-8: RECOMMENDATIONS FOR IMPROVING IPD READINESS}

\subsection{INTRODUCTION}

In the previous chapter, gaps in the IPD readiness were identified by pair-wise comparison of the case projects and two hypothetical cases. In this chapter, recommendations are provided for improvement of IPD readiness of the case study organization based on the analysis of results. The focus of the chapter is on ICT related improvement strategies. However, strategies concerning changes in business and organizational setup are also discussed. It should also be noted that although the recommendations are specifically for the organization under study, the method used in arriving at these recommendations is applicable to other owner organizations as well.

\subsection{ICT OPPORTUNITIES AND RECOMMENDATIONS}

Pair-wise comparison of the cases in Chapter 7 highlighted the instances where the use of higher-level ICT tools and methods has resulted in improved IPD readiness. It was observed that utilization of BIM-based tools for performing various project functions had positive impacts on the readiness of the principles associated with those functions. These observations are consistent with the survey findings where the respondents indicated strong agreement that ICT tools foster collaboration-related IPD principles or characteristics. The two major areas of improvement identified from the gap analysis are (1) effective uses of BIM-based tools for performing different project functions, and (2) use of centralized information system for project teams to facilitate management, processing and communication of information among project participants. Specific 
recommendations are made in the following for the organization under study. These recommendations are based on the observations from comparisons between the project cases with the hypothetical case representing the best possible scenario in a typical public owner organization that is bound by certain regulations affecting contracts. .

\subsubsection{UTILIZE BIM FOR GENERATING PROJECT CONCEPT SCENARIOS}

It has been observed from the case studies that the programming phase of a construction project is primarily conducted by utilizing in-house expertise. Facilities planning function within the facilities management department is responsible for developing the preliminary programming document based on the client requirements and available funds. The level of ICT tools and methods during programming phase has been limited to standalone spreadsheet based tools. In Table 8.1, comparison of the ICT levels for the three programming phase functions for all six case studies is shown.

Table 8.20: Comparison of ICT Levels - Programming Phase

\begin{tabular}{|l|c|c|c|c|c|c|}
\hline & $\begin{array}{l}\text { Case } \\
\mathbf{A}=32.5\end{array}$ & $\begin{array}{l}\text { Case } \\
\mathbf{B}=\mathbf{1 5}\end{array}$ & $\begin{array}{l}\text { Case } \\
\mathbf{C}=\mathbf{2 2 . 5}\end{array}$ & $\begin{array}{l}\text { Case } \\
\mathbf{D = 3 0}\end{array}$ & $\begin{array}{l}\text { Case } \\
\mathbf{E}=\mathbf{2 0}\end{array}$ & $\begin{array}{l}\text { Case } \\
\mathbf{F}=\mathbf{3 5}\end{array}$ \\
\hline Function & \multicolumn{7}{|c|}{ ICT Level } \\
\hline P1 & I & I & I & I & I & II \\
\hline P2 & I & I & I & I & I & I \\
\hline P3 & I & I & I & I & I & I \\
\hline
\end{tabular}

As explained by Tardif (2007) "Decisions are often made in the programming phase of a project that have enormous downstream implications-for aesthetics, cost, energy consumption, and the ultimate suitability of a building for its intended purposeon the basis of inaccurate, incomplete, or unreliable information". 
The quality of information at programming stage can be enhanced by utilizing BIM for conceptual modeling. As observed in the comparison between the hypothetical case $\beta$ and best project (out of six studied projects) case $\mathrm{F}$ in Table 8.2, there would have been a potential increase in the IPD readiness score related to JDPTC, if the tools and methods utilized in case $\beta$ were applied to case F. Based on the observation the specific set of recommendations for programming phase of the project is discussed below.

Table 8.21: Comparison of ICT Tools and Methods between Case F and Case $\beta$ at Programming Stage

\begin{tabular}{|l|c|l|l|l|l|}
\hline Functions & $\begin{array}{l}\text { ICT } \\
\text { Level }\end{array}$ & $\begin{array}{l}\text { ICT tools/methods } \\
\text { used }\end{array}$ & $\begin{array}{l}\text { ICT } \\
\text { Level }\end{array}$ & $\begin{array}{l}\text { ICT tools/methods } \\
\text { recommended }\end{array}$ & $\begin{array}{l}\text { IPD Principles } \\
\text { (Potential } \\
\text { Increase in score) }\end{array}$ \\
\hline & \multicolumn{1}{|c|}{ Case F } & \multicolumn{2}{|c|}{ Case $\boldsymbol{\beta}$} \\
\hline P1 & II & $\begin{array}{l}\text { SketchUp and Excel } \\
\text { Spreadsheets }\end{array}$ & III & Revit (LOD 100) & JDPTC (2.5) \\
\hline P2 & I & $\begin{array}{l}\text { Manual Estimating } \\
\text { process }\end{array}$ & III & Vico Cost Planner & JDPTC (2.5) \\
\hline P3 & I & $\begin{array}{l}\text { Manual Scheduling } \\
\text { process }\end{array}$ & III & Vico Schedule Planner & JDPTC (2.5) \\
\hline
\end{tabular}

It is suggested that, a 3D conceptual model using Revit should be developed at this stage. The model should include general information on basic parameters such as floor area, use designations, building volume, and building grids. The cost of the project should be linked with the conceptual model using Vico Cost planner to develop a costing scheme at the programming phase. For determination of project schedule Vico Schedule Planner should be utilized to incorporate information related to locations, estimated quantities, and productivity.

The reason for recommending the specific set of ICT tools is that these tools can easily be interlinked with each other. BIM at this stage facilitate faster and more informed analysis and review of several design options and alternatives by modeling the basic parameters of the project. Through BIM, it is possible to modify the model changes 
in real-time that eliminate the need of multiple design iterations which is an expensive, inefficient, and time-consuming process. Visualization of form helps all participants involved at this stage to better visualize and provide their input earlier in the project. It is because designs can begin in a 3-D model can be better understood even by those who are not engineers and thus allow them to give their input early in the project lifecycle where cost of changes is minimal. Engagement of clients and end users also ensures comprehensive requirement capture and requirement flow down (Khanzode et al. 2006; Sacks et al. 2010).

\subsubsection{DEVELOP E-SPECIFICATIONS USING e-SPECS}

Another observation that has been consistently made during the case studies analysis was that while newer projects are developing the design using advanced ICT tools, the level of ICT at which project specifications are developed is still level I as depicted in Table 8.3.

Table 8.3: Comparison of ICT Tools and Methods for Development of Specifications

\begin{tabular}{|l|l|l|l|l|c|c|}
\hline & $\begin{array}{l}\text { Case } \\
\mathbf{A = 3 2 . 5}\end{array}$ & $\begin{array}{l}\text { Case } \\
\mathbf{B = 1 5}\end{array}$ & $\begin{array}{l}\text { Case } \\
\mathbf{C = 2 2 . 5}\end{array}$ & $\begin{array}{l}\text { Case } \\
\mathbf{D = 3 0}\end{array}$ & $\begin{array}{l}\text { Case } \\
\mathbf{E = 2 0}\end{array}$ & $\begin{array}{l}\text { Case } \\
\mathbf{F = 3 5}\end{array}$ \\
\hline Function & \multicolumn{7}{|c|}{ ICT Level } \\
\hline SD2 & I & I & I & I & I & I \\
\hline DD3 & I & I & I & I & I & I \\
\hline CD3 & I & I & I & I & I & I \\
\hline
\end{tabular}

The issues related to specification errors were repeatedly observed for all case projects while analyzing RFI logs, project correspondence files and minutes of meetings. Interviews from constructions managers of cases $\mathrm{B}$ and $\mathrm{F}$ also confirmed that specifications developed as part of design documents were not linked with design. It 
resulted in errors and inconsistencies between the plans and specs were results of manual update of specifications with the changes and development in design throughout the project. Sambasivan and Soon (2007) identified that one of the most common form of compensable time delay is caused by inadequate drawings and specifications.

Seamless integration and synchronization of BIM drawings with specifications is possible through BIM integrated solutions. A specific recommendation in this regard is to utilize e-SPECS for Revit interfaces with Revit's parametric database. e-SPECS allows instant updating of project specifications to the requirements of the building model. It has the capability to automate the creation of specifications while allowing accessing those specs and other related files directly within Revit based applications. It also enables the team members to collaborate on specification documents from anywhere using internet. The project team can access the project documents directly in Revit based applications, using the e-SPECS Desktop Collaborator tools or through an Autodesk Buzzsaw online account.

\subsubsection{INTEGRATE COST AND SCHEDULES ESTIMATING AND UPDATE WITH BIM MODEL}

The next recommendation for the organization under study is related to the design and construction phases of the project lifecycle. It was observed throughout the cases that the cost and scheduling related functions were performed using level I ICT tools and methods by the standalone spreadsheet based tools with mostly manual input. These tools were mostly not interlinked with past data (cost indices and past performance data) as well as with the current project design. 
Based on comparison of ICT tools and methods used in case F and case $\beta$, as shown in Table 8.4, it can be concluded that even the most IPD ready project lacks integration of cost and scheduling. There is a potential to improve IPD readiness related to CDM, JDPTC, ID and WTC if the tools and methods utilized for developing and updating project cost and schedules are interconnected with the developed BIM model.

Table 8.4: Comparison of ICT Tools and Methods between Case F and Case $\beta$ for Cost and Schedules

\begin{tabular}{|l|l|l|l|l|l|}
\hline $\begin{array}{l}\text { Project } \\
\text { Functions }\end{array}$ & $\begin{array}{l}\text { ICT } \\
\text { Level }\end{array}$ & $\begin{array}{l}\text { ICT tools/methods } \\
\text { used }\end{array}$ & $\begin{array}{l}\text { ICT } \\
\text { Level }\end{array}$ & $\begin{array}{l}\text { ICT tools/methods } \\
\text { recommended }\end{array}$ & $\begin{array}{l}\text { IPD Principles } \\
\text { (Potential } \\
\text { Increase in score) }\end{array}$ \\
\hline & \multicolumn{2}{|c|}{ Case F } & \multicolumn{2}{|c|}{ Case $\beta$} \\
\hline SD3 & I & Primavera (P6) & III & $\begin{array}{l}\text { Vico Office (5D BIM } \\
\text { based workflow) }\end{array}$ & $\begin{array}{l}\text { CDM (5), ID (2.5), } \\
\text { JDPTC (2.5) }\end{array}$ \\
\hline DD3 & I & Primavera (P6) & III & $\begin{array}{l}\text { Vico Office (5D BIM } \\
\text { based workflow) }\end{array}$ & $\begin{array}{l}\text { CDM (5), ID (2.5), } \\
\text { JDPTC (2.5) }\end{array}$ \\
\hline CD3 & I & Primavera (P6) & III & $\begin{array}{l}\text { Vico-5D BIM based } \\
\text { workflow }\end{array}$ & $\begin{array}{l}\text { ID(2.5), CDM(5), } \\
\text { WTC (2.5) }\end{array}$ \\
\hline
\end{tabular}

Accordingly, specific recommendation for the organization is to link the 3D Revit model with Vico Office BIM based workflow so that changes in the model are automatically updated in both the schedule (4D) and cost estimates (5D). BIM model acts as an input to Vico office. Project team can perform constructability analysis, add location breakdown structure to extract location based quantity takeoffs and then can utilize it for model-based scheduling (4D), model-based estimating (5D), and also can be utilized for production control.

As discussed above, the gap identification highlighted two areas of ICT related improvements for the organization under study. The first part was based on BIM-based 
tools and method. The second part is related to project management information systems (PMIS) which is discussed in the following.

\subsubsection{INVEST IN PROJECT MANAGEMENT INFORMATION SYSTEM (PMIS)}

Efficiency of a construction project relies on the reliability and effectiveness of the information exchange between project participants throughout the project phases. A centralized project management information system is an important component of an appropriately formed project team. A system that allows changes or modifications to information by any project participant to automatically disseminate within the project team and thus ensuring that every discipline involved in the project is working with the most up-to-date information (Aouad et al. 1995). This does not only increase the efficiency and reliability of the information but takes out the need for duplication and hence a potential for errors.

In this study, none of the case projects were found to have fully utilized a centralized decision system. However, in case A, the construction manager shared their project management system $(\mathrm{CMiC})$ with the owners, A/Es and subs. This sharing of system resulted in enhancing the open communication between all participants and thus contributed to higher IPD readiness related to OC in case A. The scores of OC is shown in Table 8.5.

Table 8.5: Comparison of Case A and Case D - RFIs Management Methods

\begin{tabular}{|c|c|c|c|c|}
\hline & \multicolumn{2}{|l|}{ CASE A } & \multicolumn{2}{|l|}{ CASE D } \\
\hline Functions & \multicolumn{2}{|l|}{$\mathrm{OC}=5$} & \multicolumn{2}{|l|}{$\mathrm{OC}=2.5$} \\
\hline $\mathrm{C} 3$ & $\begin{array}{l}\text { CMiC Project Management (shared } \\
\text { with A/E, Owners and Subs) }\end{array}$ & II & CMiC (for CM use only) & I \\
\hline
\end{tabular}


The comparison between cases $F$ and $\beta$ further strengthen the proposition that use of project management information system has the potential to increase IPD readiness of an organization by positively affecting OC, WTC and FT principles. This gap analysis resulted in the following recommendation for the organization under study.

Table 8.6: Comparison of ICT Tools and Methods between Case F and Case $\beta$ for PMIS

\begin{tabular}{|c|c|c|c|c|c|}
\hline $\begin{array}{l}\text { Project } \\
\text { Functions }\end{array}$ & $\begin{array}{l}\text { ICT } \\
\text { Level }\end{array}$ & $\begin{array}{l}\text { ICT tools/methods } \\
\text { used }\end{array}$ & $\begin{array}{l}\text { ICT } \\
\text { Level }\end{array}$ & $\begin{array}{l}\text { ICT tools/methods } \\
\text { recommended }\end{array}$ & $\begin{array}{l}\text { IPD } \\
\text { Principles } \\
\text { (Potential } \\
\text { Increase in } \\
\text { score) } \\
\end{array}$ \\
\hline & \multicolumn{2}{|r|}{ Case $\mathbf{F}$} & \multicolumn{2}{|r|}{ Case $\beta$} & \\
\hline $\mathrm{C} 3$ & I & $\begin{array}{l}\text { CMiC } \\
\text { Communication (not } \\
\text { shared) }\end{array}$ & II & $\begin{array}{l}\text { CMiC Communication } \\
\text { (shared) }\end{array}$ & $\begin{array}{l}\text { OC }(5), \\
\text { WTC }(2.5)\end{array}$ \\
\hline $\mathrm{C} 4$ & I & Manual Wet signed & II & $\begin{array}{l}\text { CMiC Open Enterprise } \\
\text { v10 }\end{array}$ & $\mathrm{FT}(5)$ \\
\hline $\mathrm{C} 5$ & I & $\begin{array}{l}\text { Manual copies of all } \\
\text { records are } \\
\text { maintained }\end{array}$ & II & $\begin{array}{l}\text { CMiC Open Enterprise } \\
\text { v10 }\end{array}$ & $\mathrm{FT}(5)$ \\
\hline
\end{tabular}

The broader recommendation is to develop a collaborative project work environment where an open standard is required, information is stored in a centralized accessible database and systems are interoperable.

The first specific recommendation to achieve the broader goal is to utilize $\mathrm{CMiC}$ Communication Management shared and interoperable between all participants. This will enable tracking of all project communications and keeping stakeholders in the information loop. Thus the quality of communication between the project participants will increase, and it will allow them to collaborate more openly. In addition, a central repository of project information will reduce the need of information handling by avoiding duplication of information. 
The use of centralized information system can also be beneficial for increasing the IPD readiness score of fiscal transparency, which are currently very low for the organization. It is understandable that full electronic record keeping may not be possible under the current State regulation that mandates hardcopies of key contract administration documents be maintained. However, the centralized information system can be potentially beneficial by increasing transparency and by providing access to the financial records and contingencies to all project participants. This will not only facilitate the auditing process but will also result in increasing mutual trust between the project participants. Evidences from the previous public sector case study confirm that transparency through common access to financial record resulted in increased willingness to collaborate among the project participants (AIA 2012, p 241). In this regard, use CMiC Open Enterprise v10 software is recommended. It will provide owners electronic access to information from all the project stakeholders involved and thus will result in improving IPD readiness related to fiscal transparency.

The interview with the Director of Construction Facilities also confirmed that the communication and coordination between the project participants significantly improved in the recent projects where project information system (contractor owned) was shared with other project participants as compared to the projects where it was not shared. This also validates the recommendation that utilization of centralized information system can be beneficial to the owners and can make it more IPD ready organization.

In the subsequent discussion, the recommendations related to improvements in organizational procedures are discussed based on the identified gaps. 


\subsection{RECOMMENDATIONS FOR IMPROVING ORGANIZATIONAL PROCEDURES}

It is well established that generally public agencies do not have the authority to implement an IPD contract, which calls for shared risks and rewards and restrains from going into litigation. However, IPD-like projects can still be achieved by focusing on the collaboration-related and behavioral IPD principles. (NASFA et al. 2010). These principles can be applied largely to alternate delivery methods like $C M$ at risk and design-build where projects can be benefited from early involvement of key participants (EIKP). Following are some recommendations that can be useful for public owner organizations for implementing IPD as a philosophy, when implementation of a contractual IPD is not feasible.

\subsubsection{DEMAND BIM AS DESIGN AND CONSTRUCTION DELIVERABLE}

It has been observed that even in the recent projects, where the $\mathrm{A} / \mathrm{Es}$ and contractors utilized BIM for design development and coordination, the FIU's contracts did not require BIM as a design deliverable. The use of BIM had been the result of voluntary choice by $\mathrm{A} / \mathrm{Es}$ and contractors. In most new cases, both $\mathrm{A} / \mathrm{E}$ and contractors developed Revit models and shared with each other. In case B, however, the contractor had to develop the BIM model from 2D CAD that has been delivered to them as design deliverable. It required the contractor extra effort in form of developing construction model from 2D CAD. This situation could have been easily avoided if the contract had explicitly stated BIM as deliverable. It was also observed that the projects that employed BIM-based applications for evaluating design alternatives and design reviews performed better than the ones that did not, as indicated in Table 8.7. 
With the use of BIM, it is very convenient to perform structural, thermal and acoustic performance analyses in a considerable less time than needed by conventional means (Azhar et al. 2008). Thus, BIM enables project participants to meet more frequently and provide valuable input to design early in the design phase. Also, cost estimation and validation of conformance to client program, improves the overall design (Sacks et al. 2010). BIM applications can also support and facilitate participatory decision making by providing more and better information to all involved and by expanding the range of options that can be considered (Dehlin and Olofsson 2008). It facilitates joint development and/ validation of project target criteria and provides more reliable information inputs for collaborative decision-making.

Table 8.7: Comparison of ICT Tools and Methods for Design and Reviews

\begin{tabular}{|l|c|c|c|c|c|c|}
\hline & $\begin{array}{c}\text { Case } \\
\mathbf{A = 3 2 . 5}\end{array}$ & $\begin{array}{c}\text { Case } \\
\mathbf{B = 1 5}\end{array}$ & $\begin{array}{c}\text { Case } \\
\mathbf{C = 2 2 . 5}\end{array}$ & $\begin{array}{c}\text { Case } \\
\mathbf{D = 3 0}\end{array}$ & $\begin{array}{c}\text { Case } \\
\mathbf{E = 2 0}\end{array}$ & $\begin{array}{c}\text { Case } \\
\mathbf{F = 3 5}\end{array}$ \\
\hline Function & \multicolumn{7}{|c|}{ ICT Level } \\
\hline SD1 & III & I & I & III & I & III \\
\hline SD4 & III & I & I & III & II & III \\
\hline DD1 & III & I & I & III & I & III \\
\hline DD2 & III & I & I & III & II & III \\
\hline CD1 & III & I & I & III & I & III \\
\hline CD2 & III & I & I & III & I & III \\
\hline CD4 & I & I & I & II & I & I \\
\hline
\end{tabular}

Thus, it is recommended to clearly define the methods and BIM deliverables in the contracts. List of specific methods and deliverables should be identified and included in the agreements with the A/Es, and contractors. Additionally, BIM Execution Plan (BEP) should also be developed at the start of the project for specifying model sharing among all team members. 
When this recommendation was put forward to the director of construction facilities at FIU, she acknowledged that FIU has already started to realize the benefits of $\mathrm{BIM}$ and is considering including it in future design and construction contracts. She also added that currently FIU is evaluating its options to utilize as-built BIM documents for facilities management.

\subsubsection{PERFORM CONTINUOUS VALIDATION OF DESIGN}

Under the current practices, design reviews are usually conducted at the end of each design phase. These reviews are integral part of the decision making process related to the project and often cause changes in design. This is a major cause of waste and rework in the project. Validation and review process can be continuous when the construction expertise are available on the project during the design phase and design reviews are facilitated by the use of higher level ICTs such as Navisworks and Buzzsaw. This continuous exercise can increase the IPD readiness of the project related to 'intensified design' by increasing the frequency of communication and coordination between the project participants. It also eliminates the need of value engineering process which is a reactive approach rather than proactive and often causes rework and waste. These frequent and continuous input results in; better and constructible design; improvement in collaborative decision making; and better understanding of the design by the project team. This change is easier to implement as it does not conflict with the public procurement laws and has the ability to impact IPD readiness of an organization in terms of 'intensified design' and 'collaborative decision making'. 
It is also worth mentioning that there are several free BIM assistance tools are available, such as OpenBIM, Tekla BIMsight, AutoCAD Design Review that allows participants to review and coordinate project participants without having BIM platform. These tools can be very beneficial to owners in case they do not currently have their own BIM software.

\subsubsection{ESTABLISH COLLABORATIVE DECISION-MAKING TEAM AND PROCESSES}

It is observed that decision-making structure for case organization is long and hierarchal. Owners related decisions are often approved at the presidential level and are time consuming. Design and construction related decisions are also made in isolation with only a designer or contractor responsible for decision making depending on the project phase.

This segregation results in low IPD readiness for CDM and lost opportunities for effective ICT utilization for decision-making. This is evident in Table 7.2 where the comparatively higher-level use of ICT for cases A, D and F did not reflect back in the IPD readiness scores.

Timely and more collaborative decisions can be made if the decision-making process is decentralized and team members at appropriate level are given the authority to make decisions. Owners can play a very important part in setting up the decision making structure. Therefore, it is recommended that the decision-making group should compose of experts and representatives from at least owners, $\mathrm{A} / \mathrm{E}$ and $\mathrm{CM} / \mathrm{GC}$. 
Decision-making authorities can be designated to several teams based on the type of decisions. A three-tier collaborative decision-making structure can be established with the composition of three types of teams, namely, the executive team, the project managers' team, and the discipline team.

Executive teams should comprise of top management executives from the owner, $\mathrm{A} / \mathrm{E}$ and contractors' organizations and should be responsible for making business decisions. Project Managers' team should be empowered to make project specific decision-making. At the discipline level, team members from extended group of participants including consultants and subcontractors along with owners, A/Es and contractors should be encouraged to participate in the decision making process and should be jointly accountable for decision making.

It is important to establish a clear and well-documented decision-making process at the start of the project. The structure for decision making should be defined early in the project and should be continuously monitored, team members capable of making informed and timely decisions should be made part of the decision making group. Those who cannot work in a team setup should be identified and removed from the decision making team to facilitate the process.

\subsubsection{ENCOURAGE CO-LOCATION OF TEAMS}

Willingness to collaborate is partially dependent upon the interaction opportunities between the team members. It is observed that currently the project team members do not have sufficient opportunities to interact as for most of the projects the team members reside in their own offices separate from the rest of the project team. 
Ideas evolve when the environment is collaborative. Co-location of the $\mathrm{A} / \mathrm{E}$, contractors and owners representative under a single roof is suggested as an improvement strategy to increase IPD readiness related to willingness to collaborate. This increases the possibilities of communication and collaboration between the teams. "Big Room" setup where everyone working on the project is present in the same room enables team members working relationships to develop faster that makes better design and construction possible.

The above discussion was based on the organization's procedural gaps and recommendation to improve IPD readiness of the case study organization by making organizational changes in its procedures and processes. In the subsequent discussion, contractual changes are discussed.

\subsection{RECOMMENDATIONS FOR CONTRACTUAL CHANGES}

According to the proceedings of Building in The 21st Century: Public Construction Law Reform and Opportunities for Savings "The State's public procurement laws were enacted several decades ago under conditions and upon assumptions no longer applicable to the construction industry and its products. These laws embed delay into the design and construction of public projects with associated avoidable costs, and often require the sacrifice of designs and construction techniques that lead to long-term lower operation and maintenance costs. In a slower economy without reform, the public sector would be able to fund and complete fewer projects at a time when government's role as an economic stimulator is most needed". 
Therefore, it is necessary to bring changes in public procurement laws to deal with increasing complexities in the building process and to address higher demands of collaboration and integration of the project team.

While the procurement laws have reacted to earlier alternative delivery methods like $\mathrm{CM}$ at risk and design-build and most of the states allow these two delivery methods on state building projects (see Figure 8.1 and 8.2), most states do not allow IPD at this point.

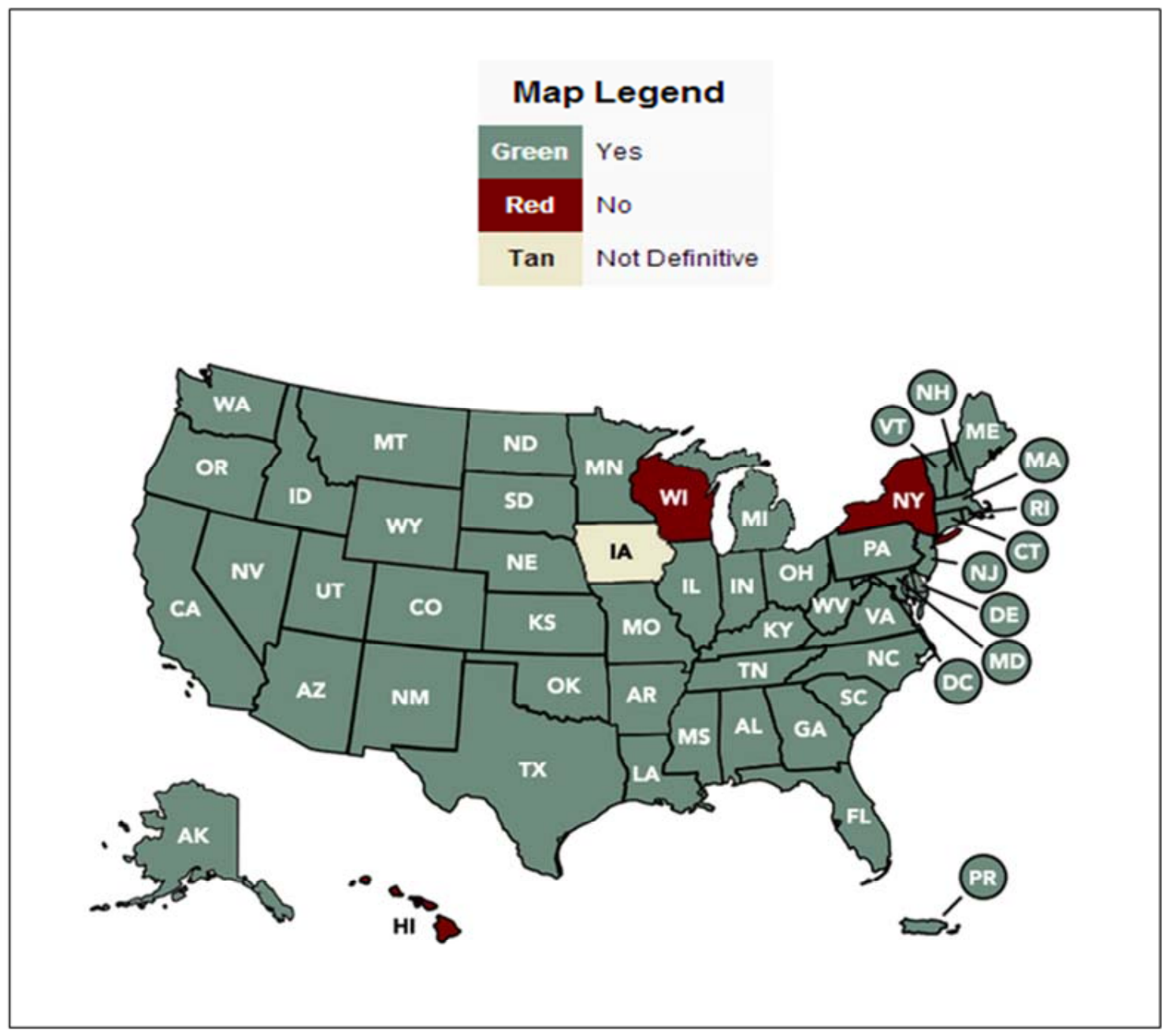

Figure 8.4: State-by-State Map for CM-at-Risk Use on Public Building Projects (Source: AGC Website) 
Some States are more proactive in understanding the needs of modern construction delivery systems than others. For example, state of Colorado now allows IPD in public projects if justified and found appropriate for particular public projects (CGA 2007). It is expected that IPD will receive increasing attention in the near future. The following set of recommendations can act as a guidelines for proposing changes to current procurement laws to facilitate IPD in future public projects.

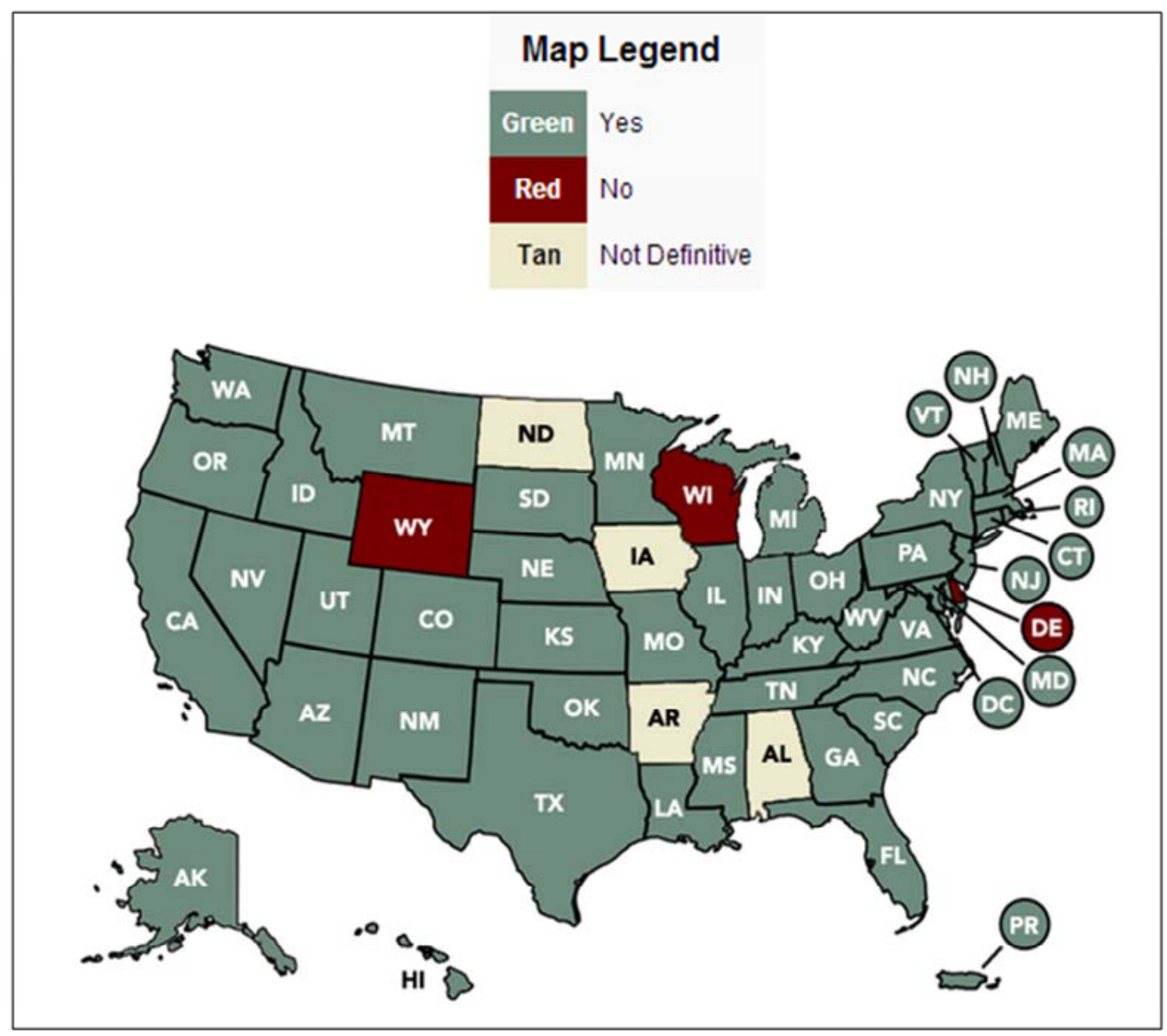

Figure 8. 5: State-by-State Map for Design-Build Use on Public Building Projects (Source: AGC Website) 


\subsubsection{IMPROVE TEAM SELECTION CRITERIA}

Currently the selection criteria for team selection is heavily dependent on related work experience and do not account for competency of the team to work in a collaborative environment with mutual respect and trust. Therefore, the MRT of team is low as observed in Table 7.1. When possible, these criteria should be included as a desired competence in the process of team selection. It is important to analyze the competency of the proposed team for the above-mentioned criteria and then make sure that the selected team members are actually present on the project.

\subsubsection{SHARE PERFORMANCE BASED INCENTIVES AMONG PARTICIPANTS}

In an ideal setup, public organization would have the authority to go into shared risk and rewards arrangement with the project team. This means the interest of all project participants are aligned and linked to project success. Pure SRR arrangement requires an IPD contract and is not possible for a majority of public owner organizations.

Alignment of interest among project participants to some extent can still be achieved by sharing performance-based incentives with the project participants. Incentives can be predetermined based on agreed project targets and can be made part of $\mathrm{A} / \mathrm{E}$ and GC contracts.

Although there are, evidences of incentive sharing with the contractors found in public projects for keeping the project within the targets. (Emerson 2006; AIA 2012), it is not very common to share performance-based incentives with other project participants such as architects and subcontractors (NASA et al. 2010). 
In the organization under study, sharing of incentives was not evident in any of the cases; further investigation led to the finding that the organization does not share performance-based incentives with project participants and is unsure of legal authorities to exercise it. Because other public organizations did share incentives with project participants, it is recommended that wherever possible, project participants are incentivized for good performance. Architects and subcontractors should also be made part of incentive sharing group along with the contractors. The incentives can also be extended to achieve non-cost related targets (like quality, sustainability etc) if important to project owners. This sharing helps in achieving goal alignment between the team members and thus increase readiness related to jointly developed project target criteria and willingness to collaborate.

\subsubsection{LIMIT LIABILITIES AMONG PROJECT PARTICIPANTS}

It has been observed that a majority of public owners do not have authority to implement liability waivers to claims among project participants in their contracts. If implemented, it can be beneficial to exercise limitations on liabilities among project participants to reduce the fear of claims and litigations among the team members. Such an arrangement can potentially increase the collaboration among project participants and will encourage sharing of innovative ideas among the project team members. In addition will also facilitate in reducing the contingencies due to liability exposure and thus will bring down the project cost.

Therefore, it is suggested that provision should be made in the current procurement laws to facilitate liability waivers among key participants. 


\subsubsection{INVOLVE SUBCONTRACTORS EARLY IN DESIGN}

Inclusion of subcontractors early during the design phase can also be very beneficial in incorporating trade expertise in design that can lead to better construction. Although the study of Florida statues does not result in any clear guidance accepting or rejecting the possibility of early involvement of subcontractors, it is not commonly practiced. Therefore, to be formally able to involve subcontractors early, it should be included in the statues.

It has been noticed that general contractors do involve subcontractors during the development of GMP but this involvement is voluntary and does not assure subcontractors work, as the selection of subcontractors is based on bidding process. However, interviews with the contractors indicated that informal involvement of subcontractors during the early design phases is possible. In such a setup, project team can benefit from the expertise and inputs from subcontractors design efforts while the only incentives to subcontractors is limited to better understanding of the design intent that might lead them to submit a competitive bid with the benefit of enhanced knowledge of the design.

\subsection{CHAPTER SUMMARY}

Recommendation related to IPD readiness improvement that were based on the gap identification process resulted from the IPD-RAM analysis, are discussed in this chapter. These recommendations can be broadly classified under informational, organization and contractual improvements. 


\section{CHAPTER-9: SUMMARY AND CONCLUSIONS}

\subsection{SUMMARY OF RESEARCH AND ITS OUTCOMES}

Public owner organizations, in general, were found to be at a disadvantage regarding implementation of integrated project delivery (IPD) method. One of the major factors contributing to this is the lack of knowledge and understanding of IPD in public

owner organizations. Thus one of the aims of this research study was to fill this knowledge gap in public owner organizations.

This research study is comprised of three major tasks (1) public owners' survey (2) development of a model to assess IPD readiness of the organization and (3) application of the model through case studies.

The results of the public owners' survey conducted as a part of this study conformed the previous findings that public owners currently do not appreciate or understand IPD. However, the survey results revealed that these owners, in general, perceive that IPD (when presented in the survey as a set of characteristics) can improve project delivery effectiveness and that advancements in ICT tools and methods (e.g. BIM) have the capability to foster IPD principles.

Based on the survey findings, the second major research task, an integrated project delivery readiness assessment model (IPD-RAM) was developed. The two major goals of IPD-RAM are:

(1) To facilitate owners to assess their current IPD readiness based on a number of IPD principles. The principles can be classified as either IPD Pull or ICT Push depending on the way they affect each other. While IPD pull principles are considered to 
attract and facilitate use of ICT, the ICT Push principles are those that are fostered and enhanced by the use of higher-level ICT tools and methods.

(2) To facilitate assessment of the level of ICT tools and methods that the organization utilizes to perform different project functions, and to determine the effect of these levels on the ICT push principles.

Further, through the application of the model it was demonstrated how the results of assessment and subsequent analyses can be utilized to identify the gaps in IPD readiness and to guide the owner organizations to develop recommendations for their organization.

The IPD-RAM and its application were validated through the feedback from a group of field experts and a focus group comprising of members from the study organization.

\subsection{CONCLUSIONS}

The following concluding remarks can be made based on the findings of this research:

Through public owner survey, the relationship between IPD and ICT from the perspective of public sector owners was investigated. It was concluded that public sector owners, in general, believe that four IPD principles namely early involvement of key participants, collaborative decision making, jointly developed project target criteria and shared risk and reward, improve project delivery effectiveness. In addition, they perceive that ICT fosters collaboration related IPD principles. But, the perception is influenced by the degree of their ICT use. More use of ICT contributes to more positive perception 
about the impact of ICT on IPD but it was found to be valid only for the internal or intraorganizational use of ICT. It was also found that two contract-related IPD characteristics, MC and LWKP are not well understood and thus remain underappreciated by the public sector owners.

As a major outcome of this research, an IPD readiness assessment model is proposed to be used by the public owners. With this model, owners should be able to assess their IPD readiness based on the ten selected IPD principles and determine their ICT levels for the twenty defined project functions across five phases of a construction project. The results of application of the model demonstrated that IPD readiness is influenced by the use of ICT tools and methods employed to perform the project functions. Higher-level ICT tools/methods are found to be associated with higher IPD readiness scores.

Thus through the survey findings and the application of IPD-RAM this research established that ICT can foster IPD and IPD can facilitate ICT.

Along with the informational barriers, it was also found that some instances, conventional organizational business setup or practices interfere or obstruct IPD readiness. Even the higher-level ICTs remain ineffective or underutilized in such organizations. The IPD readiness assessment and pair-wise comparisons between case projects were helpful in identifying problem areas where improvements can be made, and recommending improvement strategies or opportunities for the organization.

The research led to the inference that IPD can be looked from the informational, organizational and contractual perspectives. It was found that while it was collaborationrelated and behavioral IPD principles that can be achieved largely by improving the 
informational and organizational aspects of the organization, contractual principles require changes to current public procurement laws. Based on this distinction, under existing conditions, IPD can be implemented in public projects as a philosophy. However, ideal IPD (contractual) is not possible in most public projects at the current stage.

\subsection{RESEARCH CONTRIBUTIONS}

This research study makes a number of contributions and enriches the current body of knowledge in many ways, the most significant ones are listed below.

First, the survey conducted as a part of this research study, is one of the first few studies investigating how public sector owners perceive IPD, and its relation with ICT. As project owners are key stakeholders choosing a project delivery method, it is important to understand how they think about IPD. It was found in this study that although they have positive perception about IPD in general, some key IPD characteristics, 'multi-party contract' or MC being the major one, are not well understood by them.

This is also the first study that investigated the impact of ICT use on IPD with different ICT dimensions. Analysis found statistically significant perception difference exists between the two groups categorized by the degree of ICT use. The two-way ANOVA test results revealed a significant interaction effect between the type and the degree of ICT use. These findings can provide important information for future research directions to further investigate the causal relation between ICT and IPD. 
One major contribution to the body of knowledge is the IPD Readiness Assessment Model (IPD-RAM) developed to assess public owners readiness for integrated project delivery. The model is first of its kind to provide a structured approach for assessment and improvement of IPD readiness. It takes into account the major IPD principles and the levels of ICT tools and methods utilized to perform project functions. The model recognizes the difference among the IPD principles in terms of their impacts, such as contractual, collaborative and behavioral. This recognition was useful in developing the 'IPD pull' and 'ICT push' concept. IPD-RAM helps identifying the gaps in organizational use of ICT and thus can assists in formulating ICT investment strategies.

Furthermore, it also identified gaps in the organization under study from the perspective of IPD readiness. Informational, organizational and contractual aspects and barriers to IPD readiness were separately focused in this research. Thus, this is the most valuable contribution of this research. The result and analysis based on the application of the model to real case projects resulted in developing various recommendations for the study organization.

Another major contribution of the research is that while a plethora of research is present related to public sector, it is one of the few studies that focused on public owners.

\subsection{LIMITATIONS AND RECOMMENDATIONS FOR FUTURE RESEARCH}

The research findings and conclusions are limited by the scope of this research. One limitation related to the public owner survey conducted as a part of the research is the small sample size. Although this study collected data only from public sector owners, 
project types were varied. It is likely that the maturity of ICT use varies depending on the types of projects. For example, the degree of BIM adoption in the infrastructure sector is slower than that in the building sector (McGraw-Hill Construction 2012b). Thus the perceived impact of ICT use on IPD can be affected by the respondents' experiences with project types. Because of the small sample size, we did not attempt in this study to compare these variations resulting from project types.

Another limitation of this study was that the IPD-RAM was applied to only one public owner organization. The organization is a state agency. Some of the recommendations for improving IPD readiness that were presented in chapter 8 relate directly to the outcomes of the case studies. Since legal environment is different from state to state, certain strategies might not be applicable to some other states public owner organization or federal agencies.

The major focus of this research was limited to ICT push principles. The effect of IPD pull principles especially the two contractual principles are crucial for effective implementation of IPD. In future research, it is suggested that statutes and regulations impeding implementation of the contractual IPD principles are identified both for state and federal public projects.

The above limitations can lead to several future research areas. Some major future research topics are highlighted in the following discussion.

The main focus of this research was on identifying the role of information technology to improve IPD readiness. However, research also highlighted that organizational barrier were also present. Further in-depth study modeling the organizational aspects impeding the IPD readiness is suggested. 
Statutes and regulations can be scrutinized to identify contractual barriers to IPD and to develop specific legal and legislative actions. Such study could be beneficial for lawmakers to devise future statues to facilitate IPD in public sector.

One area to focus in future research studies would be to investigate the role of information systems, in general and BIM, in particular in enhancing IPD principles. The impact of information modeling on organizational arrangement and structure need to be investigated in detail for realizing the optimum benefits from IPD implementation.

In future research studies on this subject, action research approach is suggested where researchers get involved with an owner organization and the recommendations resulted from the model application and analysis of result are tested on ongoing projects (Azhar et al. 2009).

For IPD-RAM model, the levels of ICTs are defined based on currently available and utilized tools. The field of construction ICT is dynamic. It is understood that the defined levels of ICT will become obsolete in future. Therefore, the model requires frequent updates of ICT level definition.

Similar studies can be undertaken for infrastructure project owner agencies, such as state department of transportation (DOTs). Information modeling in projects (mainly horizontal) under such agencies is fundamentally different from building projects (vertical). The type of interactions among project participants in such projects is also different. In addition, infrastructure projects are increasingly utilizing public-private partnership (PPP) financial arrangement, implying very different contractual and collaborative atmosphere. Use of IPD and developing an IPD readiness model for the public owners involved in infrastructure projects will be very useful. 


\section{REFERENCES}

Adriaanse, A., Voordijk, H., and Dewulf, G. (2010). "The use of interorganisational ICT in United States construction projects." Automation in construction, 19, 73-83.

Ahmad, I. and Ahmed, S. M. (2001) "Integration in the Construction Industry: Information Technology (IT) as the Driving Force," Proceedings for the Third International Conference on Construction Project Management, Singapore 29-30 March.

Ahmad, I. U., Russell, J. S., and Abou-Zeid, A. (1995). "Information technology (IT) and integration in the construction industry." Constr.Manage.Econ., 13(2), 163-171.

Ahmad, I., Sein, M. K., and Panthi, K. (2010). "Challenges of integration and ICT's potentials in the globalized construction industry." Technology Management for Global Economic Growth (PICMET), 2010 Proceedings of PICMET '10: 1-7.

Ahuja, V., Yang, J., and Shankar, R. (2009). "Benefits of collaborative ICT adoption for building project management." Construction Innovation: Information, Process, Management, 9(3), 323-340.

AIA (2007). "Integrated Project Delivery: A Guide."Available online at http://www.aia.org/groups/aia/documents/pdf/aiab083423.pdf, Last Accessed 4 Oct 2013.

AIA (2010). "IPD Case Studies."Available online at http://hga.com/sites/default/files/downloads/resources/ipd_casestudies_aiacc fina 1010410 0.pdf, Last Accessed 24 Oct 2013.

AIA (2012). "IPD Case Studies."Available online at http://www.aia.org/aiaucmp/groups/aia/documents/pdf/aiab093702.pdf\#public, Last Accessed 24 Oct 2013.

AIA and AGC (2011). "Primer on Project Delivery."Available online at http://www.aia.org/aiaucmp/groups/aia/documents/pdf/aiab093116.pdf, Last Accessed 4 Oct 2013.

Alshawi, M., and Faraj, I. (2002). "Integrated construction environments: technology and implementation." Construction Innovation: Information, Process, Management, 2(1), 33-51.

Anumba, C. J., Bouchlaghem, N. M., Whyte, J., and Duke, A. (2000). "Perspectives on an integrated construction project model." International Journal of Cooperative Information Systems, 9(3), 283-313. 
Aouad, G., Kirkham, J., Brandon, P., Brown, F., Child, T., Cooper, G., Ford, S., Oxman, R., and Young, B. (1995). "The conceptual modelling of construction management information." Autom. Constr., 3(4), 267-282.

Ashcraft, H. W. (2012). The IPD Framework, Available online at http://www.hansonbridgett.com/Publications/pdf/ /media/Files/Publications/IPD Framework.pdf, Last Accessed 4 May 2014.

Autodesk. (2008). "Improving Building Industry Results through Integrated Project Delivery and Building Information Modeling." Available online at http://images.autodesk.com/adsk/files/bim_and ipd whitepaper.pdf, Last Accessed 4 May 2014.

Azhar, S., Hein, M., and Sketo, B. (2008). "Building information modeling: Benefits, risks and challenges." Proc., 44th Associated Schools of Construction National Conference, Auburn, AL.

Azhar, S. (2005) "Information Systems to Support Decision Making in Construction Owner Organizations :A Data Warehousing Approach.” Ph.D. Dissertation, Florida International University.

Azhar, S., Ahmad, I., and Sein, M. K. (2009). "Action research as a proactive research method for construction engineering and management." J.Constr.Eng.Manage., 136(1), 87-98.

Back, W. E., and Moreau, K. A. (2001). "Information management strategies for project management." Project Management Journal, 32(1), 10-19.

Bjork, B. C. (1994). "Conceptual models of product, project, and document data: Essential ingredients of CIC.” Proc., Computing in Civil Engineering Conf., ASCE, Washington, D.C., 980-987.

Briscoe, G., and Dainty, A. (2005). "Construction supply chain integration: an elusive goal?" Supply Chain Management: An International Journal, 10(4), 319-326.

Brown, A., Rezgui, Y., Cooper, G., Yip, J., and Brandon, P. (1996). "Promoting computer integrated construction through the use of distribution technology." J. ITCON, 1, 51-67, (http://www.itcon.org/1996/3/paper.pdf).

Cao, Y., Chau, K., Anson, M., and Zhang, J. (2002). "An intelligent decision support system in construction management by data warehousing technique." Engineering and deployment of cooperative information systems, Springer, 360-369.

CGA, C. G. A. (2007). "Integrated project delivery methods - state, county, and municipal governments and specified special districts - contracts for public projects." H.B. 07-1342, C. State, ed. Available Online at 
http://www.state.co.us/gov_dir/leg_dir/olls/digest2007a/GOVERNMENTSTATE. htm\#07-1342, Last Accessed 25 Oct. 2013.

Cheng, J. C., Law, K. H., Bjornsson, H., Jones, A., and Sriram, R. (2010). "A service oriented framework for construction supply chain integration." Autom.Constr., 19(2), 245-260.

Cleves Jr., J. A., and Gallo, L. D. (2012). "Integrated Project Delivery: The Game Changer." 2012 Annual Meeting Advanced Project Delivery: Improving the Odds of Success, American Bar Association, Las Vegas, NV.

Constructing Excellence. (2004). "Effective Teamwork: A Best Practice Guide for the Construction Industry" Constructing Excellence, London.

Construction Industry Institute (2011) Information Integration to Improve Capital Project Performance.

CURT (2004) Collaboration, Integrated Information, and the Project Lifecycle in Building Design and Construction and Operation Construction Users Roundtable, USA WP-1202.

Dehlin, S., and Olofsson, T. (2008). "An evaluation model for ICT investments in construction projects." Journal of Information Technology in Construction, 13 343-361.

Den Otter, A., and Prins, M. (2002). "Architectural design management within the digital design team." Engineering Construction and Architectural Management, 9(3), 162-173.

Dossick, C. S., and Sakagami, M. (2008). "Implementing Web-Based Project Management Systems in the United States and Japan." Journal of Construction Engineering and Management, 134(3), 189-196.

Dossick, C., Azari, R., Kim, Y., and El-Anwar, O. (2013). "IPD in Practice: Sustaining Collaboration in Healthcare Design and Construction." AEI 2013, 377-386.

Eastman, C. M., Teicholz, P., Sacks, R., and Liston, K. (2008). BIM handbook: A guide to building information modeling for owners, managers, architects, engineers, contractors, and fabricators. Wiley, Hoboken, N.J.3.

Eckblad, S., Ashcraft, H., Audsley, P., Blieman, D., Bedrick, J., and Brewia, C. (2007). "Integrated project delivery-A working definition." AIA California Council, Sacramento, Calif.

El Asmar, M., Hanna, A., and Loh, W. (2013). "Quantifying Performance for the Integrated Project Delivery System as Compared to Established Delivery 
Systems." Journal of Construction Engineering and Management, 139(11), 04013012 .

El-Gohary, N. M., and El-Diraby, T. E. (2009). "Dynamic knowledge-based process integration portal for collaborative construction." J.Constr.Eng.Manage., 136(3), $316-328$

Erdogan, B., Anumba, C. J., Bouchlaghem, D., and Nielsen, Y. (2008). "Collaboration environments for construction: Implementation case studies." Journal of Management in Engineering, 24(4), 234-244.

Fallon, K. K. \& Hagan, S. R. (2006). Report on integrated practice. The American Institute of Architects (AIA). Retrieved from www.aia.org.

Faraj, I., and Alshawi, M. 1999. "A modularised integrated computer environment for the construction industry: SPACE." J. ITCON, 4, 37-52.

FIATECH. (2006). "Capital projects technology roadmap initiative."

Forbes, L. S., and Ahmed, S. M. (2010). Modern Construction: Lean Project Delivery \& Integrated Practices. Taylor \& Francis .

Froese, T. M. (2010). "The impact of emerging information technology on project management for construction." Autom.Constr., 19(5), 531-538.

Froese, T.(2002). "Final programme evaluation report-Vera-Information networking in the construction process."

(http://cic.vtt.fi/vera/Documents/Froese_Final_VERA_Evaluation_020926.pdf)

Galbraith, J. R., (1977), Organization Design, Addison-Wesley, p. 49 ff.

Gilligan, B., and Kunz, J. (2007). "VDC Use in 2007: Significant Value, Dramatic Growth, and Apparent Business Opportunity." CIFE, Report \#171, Stanford University.

Glick, S., and Guggemos, A. (2009). "IPD and BIM: Benefits and opportunities for regulatory agencies." Proc., 45th Associated Schools of Construction National Conference, Gainesville, FL.

Gokhale, S. (2011). "Integrated Project Delivery Method for Trenchless Projects." American Society of Civil Engineers, 604-614.

Halpin, D. W., and Senior, B. A. (2010). Construction Management, John Wiley \& Sons, Inc.

Hardin, B. (2009). BIM and construction management, Wiley, Indianapolis, IN. 
Hu, W. Conceptual Framework of Information Retrieve and Reuse in Construction Projects, 2008 International Conference on Advanced Computer Theory and Engineering (ICACTE 2008), Phuket Island, Thailand.

Hutchinson, A., and Carter, J. (2004). "Project alliances-Commercial alignment discussion paper." Alchimie Pty Ltd., Sydney.

Ibbs, C., Kwak, Y., Ng, T., and Odabasi, A. (2003). "Project Delivery Systems and Project Change: Quantitative Analysis." J.Constr.Eng.Manage., 129(4), 382-387.

Ibrahim, K. I., Costello, S. B., and Wilkinson, S. (2013). "Key practice indicators of team integration in construction projects: a review." Team Performance Management, 19(3/4), 132-152.

Johnson, T., Feng, P., Sitzabee, W., and Jernigan, M. (2013). "Federal Acquisition Regulation Applied to Alliancing Contract Practices." J.Constr.Eng.Manage., 139(5), 480-487.

Kajewski, S. L., Mohamed, S., Tilley, P. A., Crawford, J. R., Chen, S., Lennard, D., Brewer, G., Gameson, R., Kolomy, R., and Martins, R. (2001). "A Brief Synopsis in the Use of ICT and ICPM in the Construction Industry.".

Kent, D., and Becerik-Gerber, B. (2010). "Understanding Construction Industry Experience and Attitudes toward Integrated Project Delivery." J.Constr.Eng.Manage., 136(8), 815-825.

Khanzode, A., Fischer, M., Reed, D., and Ballard, G. (2006). "A Guide to applying the principles of virtual design \& construction (VDC) to the lean project delivery process." CIFE, Stanford University, Palo Alto, CA .

Lam, P., Wong, F., and Tse, K. (2010). "Effectiveness of ICT for Construction Information Exchange among Multidisciplinary Project Teams." J.Comput.Civ.Eng., 24(4), 365-376.

Lee, H., Anderson, S., Kim, Y., and Ballard, G. (2013). "2014 CEC] Advancing the Impact of Education, Training, and Professional Experience on Integrated Project Delivery." Pract.Period.Struct.Des.Constr .

Lehtiranta, L. (2011). "Relational Risk Management in Construction Projects: Modeling the Complexity." Leadership Manage.Eng., 11(2), 141-154.

Matthews, O., and Howell, G. A. (2005). "Integrated project delivery an example of relational contracting." Lean Construction Journal, 2(1), 46-61. 
McGraw-Hill Construction (2012). "The business value of BIM in North America: multiyear trend analysis and user ratings (2007-2012)." Smart Market Report. New York: McGraw-Hill.

McGraw-Hill Construction (2012b). "The business value of BIM for infrastructure." Smart Market Report. New York: McGraw-Hill.

Mitropoulos, P. and Tatum, C.B. (2000), "Management-Driven Integration," Journal of Management in Engineering. ASCE, p. 48-58.

NASFA, COAA, AHEFO, AGC, and AIA (2010). "Integreated Project Delivery for Public and Private Owners."Available online at http://www.agc.org/galleries/projectd/IPD\%20for\%20Public\%20and\%20Private \%20Owners.pdf, Last Accessed 24 Oct 2013.

Nikas, A., Poulymenakou, A., and Kriaris, P. (2007). "Investigating antecedents and drivers affecting the adoption of collaboration technologies in the construction industry." Autom.Constr., 16(5), 632-641.

Nikles, R. (2012). "Integrated Project Delivery and the Cost Curve: Are the Metrics in?" California Constructor Available online http://www.rjo.com/PDF/Integrated_Project-Delivery.pdf, Last Accessed 24 Oct 2013.

Nitithamyong, P., and Skibniewski, M. J. (2004). "Web-based construction project management systems: how to make them successful?" Autom.Constr., 13(4), 491506.

Noble. C., "Can Project Alliancing Agreements Change the Way We Build?," Architectural Record, July 2007, at p. 1.

O'Brien, W. J. (2000). "Implementation issues in project web-sites: A practitioner's viewpoint." Journal of Management in Engineering, 16(3), 34-39.

Ogunlana, S. O., Li, H., Sukhera, F.A. (2003). "System Dynamics Approach to Exploring Performance Enhancement in a Construction Organization." Journal of Construction Engineering and Management, 129(5), 528-536.

Sabol, L. Building Information Modeling \& Facility Management. 2008 .

Sacks, R. (2013). "Modern Construction: Lean Project Delivery and Integrated Practices." Constr.Manage.Econ., 31(4), 394-396. 
Sacks, R., Koskela, L., Dave, B., and Owen, R. (2010). "Interaction of Lean and Building Information Modeling in Construction." Journal of Construction Engineering and Management, 136(9), 968-980.

Sambasivan, M., and Soon Y.W. (2007) Causes and effects of delays in Malaysian construction industry. International Journal of Project Management 25, 517-526.

Shrestha, P. P., Migliaccio, G. C., O'Connor, J. T., and Gibson, G. E. (2007). "Benchmarking of Large Design-Build Highway Projects: One-to-One Comparison and Comparison with Design-Bid-Build Projects." Transportation Research Record: Journal of the Transportation Research Board, 1994(1), 17-25.

Shrestha, P., O’Connor, J., and Gibson, G. (2012). "Performance Comparison of Large Design-Build and Design-Bid-Build Highway Projects." Journal of Construction Engineering and Management, 138(1), 1-13.

Sive, T. (2009). "Integrated project delivery: Reality and promise, a strategist's guide to understanding and marketing IPD., Society for Marketing Professional Services Foundation.

Skibniewski, M.J. and Abduh, M. (2000). Web-Based Project Management for Construction: Search for Utility Assessment Tools. Implementing IT to Obtain a Competitive Advantage in the $21^{\text {st }}$ Century, Proceedings of International Conference on Construction Information Technology 2000 (INCITE 2000), Hong Kong, January 17-18, 56-77.

Staub-French, S., and Khanzode, A. (2007). "3D and 4D modeling for design and construction coordination: issues and lessons learned." ITcon, 12 381-407.

Succar, B. (2009). "Building information modelling framework: A research and delivery foundation for industry stakeholders." Automation in construction, 18, 357-375.

Tardif, M. (2007). "Architect Creates Design Synthesis Software." The News of America's Community of Architects, 14(August).

Taylor, J. E., and Bernstein, P. G. (2009). "Paradigm Trajectories of Building Information Modeling Practice in Project Networks." Journal of Management in Engineering, 25(2), 69-76.

Teicholz, P., and Fischer, M. (1994). "Strategy for computer integrated construction technology." J. Constr. Eng. Manage., 1201, 117-131.

Thomsen, C., Darrington, J., Dunne, D., and Lichtig, W. (2010). "Managing integrated project delivery." White paper of the Construction Management Association of America. 
VERA. (2006). "Information networking in the construction process." (http://cic.vtt.fi/vera/index.htm).

VTT. (2006). “The technical research centre of Finland.”(http://cic.vtt.fi/ projects/index.html).

Wickersham, J. (2009). "Legal and Business Implications of Building Information Modeling (BIM) and Integrated Project Delivery (IPD)." Available online at http://isites.harvard.edu/fs/docs/icb.topic552698.files/Wickersham\%20BIMIPD\%20legal\%20and\%20business\%20isssues.pdf, Last Accessed 15 June 2014. 
APPENDIX A

PUBLIC OWNER SURVEY 


\section{Welcome!}

It has been widely reported through literature that information modeling impacts the business processes of construction organization. However, further investigation is needed to understand how information modeling contributes to improvement of project delivery process and the current status of the US public owner organizations. This survey aims to study the issue involved with the project delivery systems and information and communication exchange patterns in construction owner organizations. The main objectives to conduct the survey are as follows:

To understand the current status of project delivery methods used in the US public sector, and To evaluate the information and communication exchange patterns in public owner organizations.

The survey is designed to take not more than 15 minutes. Your contribution towards this study is greatly appreciated, as it will add significantly to the value of this research. ALL INFORMATION PROVIDED WILL REMAIN STRICTLY CONFIDENTIAL, AND DATA WILL BE STORED AND SECURED AT PROTECTED LOCATION. In the event of a publication or presentation resulting from this research, no personally identifiable information will be shared. The respondent(s) are asked to contribute by providing requested information, and additionally to provide access to documents or additional contacts who can better answer the questions. 


\section{Section A: Organization Profile}

(Please answer the questions below with appropriate level of your application. For example, you can answer the questions thinking about your organization or your business unit/district/division).

1) What describes your organization or unit, as appropriate, the best? (select one)

O Local government

State government

Federal government

O Educational institution

Other (please specify)

2) What type of construction projects (all projects requiring contractual delivery including design/maintenance/ remediation) is your organization or unit involved with? (select all that apply)

ㅁfice buildings

R Roads and highways

口 Recreational facilities

ㅁ. Educational facilities

O Other infrastructure (water/sewer, etc.)

Other (please specify)

3) What is the total number of employees in your organization or unit involved in development and management of construction projects?

O 1 to 25

○ 25 to 50

O 51 to 100

O $>100$

4) What is the organization's or unit's annual construction capital spending?

O $<\$ 1$ million

O $\$ 1$ million to less than $\$ 10$ million

O $\$ 10$ million to less than $\$ 50$ million

O $\$ 50$ million to less than $\$ 100$ million

O $\$ 100$ million to less than $\$ 500$ million

○ $>\$ 500$ million

5) What is the typical number of construction projects undertaken by your organization or unit annually?

O 1 to 5

O 6 to 10

O 11 to 25

O 26 to 50

O More than 50 
6) In a typical project, which of the following are done in-house or outsourced by your organization or unit? Please indicate the extent.

--In-house/Outsourced------------------------------>

\begin{tabular}{|l|l|l|l|l|l|}
\hline & $100 / 0 \%$ & $75 / 25 \%$ & $50 / 50 \%$ & $25 / 75 \%$ & $0 / 100 \%$ \\
\hline Initial planning (feasibility study) & & & & & \\
\hline $\begin{array}{l}\text { Design and development of } \\
\text { specifications }\end{array}$ & & & & & \\
\hline Estimating and budgeting & & & & & \\
\hline Value engineering & & & & & \\
\hline Construction & & & & & \\
\hline Operation and maintenance & & & & & \\
\hline
\end{tabular}

7) Does your organization or unit has an information technology (IT) unit/department to assist with computer and Internet usage, data exchange and other electronic communication needs?

O Yes

O No

7.a) If yes, how long ago had this information technology (IT) unit/department been created in your organization or unit?

O 2 years ago (1)

O 2 to less than 5 years ago (2)

O 5 to less than 10 years ago (3)

O 10 to less than 15 years ago (4)

O More than 15 years ago (5)

Section B: Project Delivery

8) Please indicate, in last year, how many completed and ongoing projects by your organization or unit have used the following project delivery systems?

\begin{tabular}{|l|l|}
\hline Design/bid/build & Extent of Use (in Numbers) \\
\hline Design/build & \\
\hline CM at risk & \\
\hline CM - agency & \\
\hline Other - please specify & \\
\hline
\end{tabular}


9) Please indicate the extent of influence each factor (project budget, project duration and design/specifications) has on the selection of a particular project delivery system.

\begin{tabular}{|l|l|l|l|l|l|l|l|l|l|}
\hline & \multicolumn{3}{|c|}{ Project budget } & \multicolumn{5}{c|}{ Project duration } & \multicolumn{1}{c|}{ Design/specifications } \\
\hline Significant & Somewhat & $\begin{array}{c}\text { Not } \\
\text { at all }\end{array}$ & Significant & Somewhat & $\begin{array}{c}\text { Not at } \\
\text { all }\end{array}$ & Significant & Somewhat & $\begin{array}{c}\text { Not } \\
\text { at all }\end{array}$ \\
\hline Design/build & & & & & & & & & \\
\hline CM at risk & & & & & & & & & \\
\hline CM - agency & & & & & & & & & \\
\hline $\begin{array}{l}\text { Other - please } \\
\text { specify }\end{array}$ & & & & & & & & & \\
\hline
\end{tabular}

10) Please indicate the extent of influence each factor (project risk, procurement/Acquisition regulations, and information/communication needs of project) has on the selection of a particular project delivery system.

\begin{tabular}{|c|c|c|c|c|c|c|c|c|c|}
\hline & \multicolumn{3}{|c|}{ Project risk } & \multicolumn{3}{|c|}{$\begin{array}{l}\text { Procurement /acquisition } \\
\text { regulations }\end{array}$} & \multicolumn{3}{|c|}{$\begin{array}{l}\text { Information/communication needs } \\
\text { of project }\end{array}$} \\
\hline & Significant & Somewhat & $\begin{array}{l}\text { Not } \\
\text { at all }\end{array}$ & Significant & Somewhat & $\begin{array}{l}\text { Not } \\
\text { at all }\end{array}$ & Significant & Somewhat & $\begin{array}{l}\text { Not } \\
\text { at all }\end{array}$ \\
\hline Design/bid/buil & & & & & & & & & \\
\hline Design/build & & & & & & & & & \\
\hline $\mathrm{CM}$ at risk & & & & & & & & & \\
\hline CM - agency & & & & & & & & & \\
\hline $\begin{array}{l}\text { Other - please } \\
\text { specify }\end{array}$ & & & & & & & & & \\
\hline
\end{tabular}

11) a. Please indicate the extent of influence each contract type (Lump-sum, Cost-plus) has on the selection of a particular project delivery system.

\begin{tabular}{|l|l|l|l|l|l|l|}
\hline & Significant & Somewhat & Not at all & Significant & Somewhat & Not at all \\
Design/bid/build & & & & & & \\
\hline Design/build & & & & & & \\
\hline CM at risk & & & & & & \\
\hline CM - agency & & & & & & \\
\hline $\begin{array}{l}\text { Other - please } \\
\text { specify_ }\end{array}$ & & & & & & \\
\hline
\end{tabular}


11) b. Please indicate the extent of influence each contract type (Unit price, and Guaranteed maximum price) has on the selection of a particular project delivery system.

\begin{tabular}{|l|l|l|l|l|l|l|}
\hline & Significant & Somewhat & Not at all & Significant & Somewhat & Not at all \\
\hline Design/bid/build & & & & & & \\
\hline Design/build & & & & & & \\
\hline $\mathrm{CM}$ at risk & & & & & & \\
\hline $\mathrm{CM}$ - agency & & & & & & \\
\hline $\begin{array}{l}\text { Other - please } \\
\text { specify }\end{array}$ & & & & & & \\
\hline
\end{tabular}

12) Indicate the approximate classification (in \%) of your projects in recent years in terms of performance regarding budget. (total should add up to $100 \%$ )

Over budget (\%)

On budget (\%)

Under budget (\%)

13) Indicate the approximate classification (in \%) of your projects in recent years in terms of performance regarding schedule. (total should add up to $100 \%$ )

$$
\begin{aligned}
& \text { Ahead of schedule (\%) } \\
& \text { On schedule (\%) } \\
& \text { Behind schedule (\%) }
\end{aligned}
$$

14) Indicate the approximate classification (in \%) of your projects in recent years in terms of performance regarding quality. (total should add up to $100 \%$ ) Below expectations (\%) Met expectations (\%)

\begin{tabular}{|c|c|c|c|}
\hline & Yes & No & Not sure \\
\hline \multicolumn{4}{|l|}{$\begin{array}{l}\text { Early involvement of key participants (team including designer, constructor } \\
\text { and trade contractors that help the owner to crystallize the project's goals and } \\
\text { objectives from very early on and collaborate throughout the project.) (1) }\end{array}$} \\
\hline \multicolumn{4}{|l|}{$\begin{array}{l}\text { Shared risk and reward (participating team members mutually benefit when } \\
\text { project cost savings are achieved and mutually share the risk of cost overruns.) (2) }\end{array}$} \\
\hline \multicolumn{4}{|l|}{$\begin{array}{l}\text { Multi-party contract (the parties execute one coordinated and integrated } \\
\text { agreement that clearly sets forth the parties' role and responsibilities in delivering a } \\
\text { project.) (3) }\end{array}$} \\
\hline \multicolumn{4}{|l|}{$\begin{array}{l}\text { Collaborative decision making and control (the parties need to agree upon a } \\
\text { clear and specific set of criteria which can be established according to the owner's } \\
\text { goal for the project.) (4) }\end{array}$} \\
\hline \multicolumn{4}{|l|}{$\begin{array}{l}\text { Liability waivers among key participants (main parties waive any claim } \\
\text { amongst themselves except for in the instance of a willful default to reinforce the } \\
\text { sense of unity and a collaborative environment.) (5) }\end{array}$} \\
\hline $\begin{array}{l}\text { Jointly developed and validated project goals (owner, with the help of the } \\
\text { project team clearly defined achievable goals defines the metrics for measuring } \\
\text { them and provides appropriate incentives for achieving them.) (6) }\end{array}$ & & & \\
\hline
\end{tabular}
Exceeded expectations (\%)

15) Do you think the following characteristics would improve effectiveness in project delivery system(s)? 


\section{Section C: Information and Communication Exchange}

16) Please indicate the type of use (internal or external) of the listed ICT (information and communication technology) tools and techniques by your organization. (check both if appropriate) Internal - within your own organization and its units. Externalwith other organization/companies involved in the project.

\begin{tabular}{|l|l|l|}
\hline \multicolumn{1}{|c|}{ Internal } & \multicolumn{1}{c|}{ External } \\
\hline Emails with attachments & & \\
\hline Fax & & \\
\hline Project planning software & & \\
\hline Estimating software & & \\
\hline Payroll processing software & & \\
\hline Building information modeling (BIM) & & \\
\hline 3D CAD software & & \\
\hline $\begin{array}{l}\text { Microsoft office suite (Excel, Access, } \\
\text { PowerPoint, etc.) }\end{array}$ & & \\
\hline Project websites (designated users only) (9) & & \\
\hline Others Please Specify & & \\
\hline
\end{tabular}

17) How are the following documents transmitted to and from your organization?

\begin{tabular}{|c|c|c|c|c|c|}
\hline & $100 / 0 \%$ & $75 / 25 \%$ & $50 / 50 \%$ & $25 / 75 \%$ & $0 / 100 \%$ \\
\hline \multicolumn{6}{|l|}{ Letters/ memos (internal) } \\
\hline \multicolumn{6}{|l|}{ Letters/ memos (external) } \\
\hline \multicolumn{6}{|l|}{ Plans/ shop drawings } \\
\hline \multicolumn{6}{|l|}{ Design and specifications } \\
\hline \multicolumn{6}{|l|}{$\begin{array}{l}\text { Schedules (e.g. Primavera } \\
\text { files) }\end{array}$} \\
\hline \multicolumn{6}{|l|}{$\begin{array}{l}\text { Estimates/bill of quantities } \\
\text { (spreadsheets/estimating } \\
\text { programs) }\end{array}$} \\
\hline \multicolumn{6}{|l|}{ Purchase orders } \\
\hline \multicolumn{6}{|l|}{ Bid documents } \\
\hline \multicolumn{6}{|l|}{ Contracts } \\
\hline \multicolumn{6}{|l|}{ Transmittals, e.g., RFIs } \\
\hline \multicolumn{6}{|l|}{ Change orders, etc. } \\
\hline Payments - fund transfers & & & & & \\
\hline
\end{tabular}


18) In your opinion, does use of electronic tools, such as BIM (Building Information Modeling), for sharing project data/ information within organization and between organizations have potential to foster the following characteristics in the construction projects?

\begin{tabular}{|l|l|l|l|}
\hline Early involvement of key participants & \multicolumn{1}{|c|}{ Yes } & No & Not Sure \\
\hline Shared risk and reward & & & \\
\hline Multi-party contract & & & \\
\hline Collaborative decision making and control & & & \\
\hline Liability waivers among key participants & & & \\
\hline Jointly developed and validated project goals & & & \\
\hline
\end{tabular}

Comments

Comments, if any (please write any comments you might have on the topic of this research).

\section{Contact Information (Optional)}

Organization name:

(State):

Organization location (City)

Your name;

no:

Please indicate if you would like to be acknowledged in the report (your specific response to this questionnaire will not be associated with your identity).

$\mathrm{O} \quad \mathrm{Yes}$

O No

Would you like to have a copy of the report?

O Yes

O No
Organization location

Phone 
APPENDIX B

EXPERT SURVEY THEMES 
Jointly Developed Project Target Criteria

1. Cost scheduling and estimating tools that are linked with linked with historical cost and performance parameters as compared to isolated tools without any such linkages helps project participants in better defining project target criteria?

2. Cost estimating and scheduling software also capable of performing risk event impact assessment, and What-if scenario impact analyses further enhances inputs, support and buy-in from all key project participants to jointly develop project target criteria?

3. Use of BIM to review different design alternatives and analyze modifications in realtime can facilitate joint develop project target criteria as compared to tools that supports isolated analysis and design reviews

\section{Intensified Design}

4. Developing and sharing of 3D drawings as compared to 2D CAD have a potential to increase the participation and inputs of owners, contractors and subcontractors to better understanding of probable implications of design decisions

5. Developing and sharing of BIM as compared 3D drawings have a potential to further enhance the participation and inputs of owners, contractors and subcontractors in of design

6. Use of BIM to review different design alternatives and analyze modifications in realtime can facilitate has potential to increase interaction between the project participants to provide input to design as compared to tools that supports isolated analysis and design reviews

Collaborative Decision Making

7. Integrated cost and schedule models as compared to isolated schedules and cost estimates leverages pools of expertise and encourages joint accountability for making project decisions

8. Use of BIM for design coordination (clash detection) leverages pools of expertise and encourages joint accountability for making project decisions?

9. Use of web-based system to communicate RFIs electronically between project participants allows for increased team participation and faster decision making as compared to manual exchange of RFIs using facsimiles or emails.

10. BIM support tools that allows generation to RFI directly from the BIM and update of information as available facilitates the swift decision making and joint accountability for making project decisions?

Fiscal Transparency

11. Central information system that allows Owners to track all transactions, create audit trails and produce reports electronically helps in achieving higher fiscal transparency as compared to manage paper based records.

12. Central project management information system that provides project participants access to each other's open books allows achieving higher fiscal transparency as compared to records that are stored at multiple locations and multiple project participants?

Open communication 
13. During project planning meetings, the use of electronic projection of the scheduling software as compared to conventional "sticky note" on whiteboard method facilitates the swift decision making and helps project participants to open, honest communication

14. During project planning meetings, Smart Boards (that allow project participants to directly draw the plans that can be linked into the software to create the baseline CPM) as compared to electronic projection of the scheduling software further enhances open, honest communication

15. Use of web-based system to communicate RFIs electronically between project participants allows open communication as compared to manual exchange of RFIs using facsimiles or emails.

Willingness to collaborate

16. Integrated cost and schedule models as compared to isolated schedules and cost estimates improves willingness to collaborate

17. Cost estimating and scheduling software linked with risk event impact assessment, and What-if scenario impact analyses further enhances willingness to collaborate

18. Use of BIM to review different design alternatives and analyze modifications in realtime can facilitate willingness to collaborate as compared to tools that supports isolated analysis and design reviews by allowing participants to foresee the complete picture 
VITA

\section{NIDA AZHAR}

2002-2005

2006-2008

2006-2008

2008-Present

$2010-2014$
B.E., Urban Engineering

NED University of Engineering \& Technology

Karachi, Pakistan

M.E.M, Engineering Management (Construction)

NED University of Engineering \& Technology

Karachi, Pakistan

Lecturer

NED University of Engineering \& Technology

Karachi, Pakistan

Assistant Professor (On Study Leave)

NED University of Engineering \& Technology

Karachi, Pakistan

Doctoral Candidate

Florida International University

Miami, Florida

Research Assistant

Florida International University

Miami, Florida

\section{PUBLICATIONS AND PRESENTATIONS}

Azhar, N., Kang, Y., and Ahmad, I., "A Critical Look into the Relationship between Information and Communication Technology (ICT) and Integrated Project Delivery (IPD) in Public Sector Construction, "J. of Manage. Engg. (accepted for publication)

Farooqui, R., and Azhar, N., (2008). "Designing for Construction Safety - A Construction Management Approach," Proceedings of the $14^{\text {th }}$ Rinker International Conference on Evolution of Directions in Construction Safety and Health, Gainesville, Florida, March 911, pp. 130-143

Azhar, N., Farooqui, R., and Ahmed, S. M., (2008.) "Cost Overrun Factors in Construction Industry of Pakistan," Proceedings of the $1^{\text {st }}$ International Conference on Construction in Developing Countries, Karachi, Pakistan, August 4-5, pp. 499-508. 
Arif, F., Gazder, U., Azhar, N., and Farooqui, R.,(2008). "Construction Risk Insurance in Pakistan," Proceedings of the $1^{\text {st }}$ International Conference on Construction in Developing Countries, Karachi, Pakistan, August 4-5, pp. 177-184.

Farooqui, R., Azhar, N., Lodi S. H., and Rafeeqi, S. F. A., (2009). Quantifying the Criteria for Performance Appraisal of Project Managers in Pakistani Construction Industry," presented at the Fifth International Conference on Construction in the 21st Century, Istanbul, Turkey, May 20-22, pp. 682-693.

Farooqui, R.,and Azhar, N., (2009). "Trends of Cost Overruns in the Construction Industry of Pakistan, "Proceedings of the International Symposium on Construction in Developing Economies; Commonalities among Diversities, Penang, Malaysia, October 57.

Azhar, N., and Rafeeqi, S. F. A., (2010). "Conflicts at Design and Construction Interface in Construction Industry-Special Reference to Pakistan," proceedings of the $2^{\text {nd }}$ International Conference on Construction In Developing Countries, Cairo, Egypt, August 3-5, pp. 913-921.

Panthi, K., Ahmad, I., Azhar, N., and Arif, F. (2010). "Regional Analysis of International Construction Market Share and Impact of Financial Crisis, " proceedings of the $2^{\text {nd }}$ International Conference on Construction In Developing Countries, Cairo, Egypt, August 3-5, pp. 962-972.

Azhar, N., and Ahmad, I., (2011). "Internet-Based ICT usage in Construction Project Management: A Global Appraisal,". proceedings of the Sixth International Conference on Construction in the 21st Century, Kuala Lumpur, Malaysia, July 5-7.

Arif F., Azhar N. and Bayraktar M. E., (2012). Strategic Management Concepts and Practices in Pakistan: A Construction Industry Perspective," proceedings of the Construction Research Congress 2012: Construction Challenges in a Flat World, West Lafayette, Indiana, May 21-23, pp. 1530-1539.

Azhar, N., (2012). "Integrated Construction Project Delivery Systems in the Us Public Sector: An Information Modeling Framework" poster presented at Construction Research Congress 2012: Construction Challenges in a Flat World, PhD Student Poster Session, West Lafayette, Indiana, May 21-23.

Azhar, N., Kang, Y., and Ahmad, I., (2013). "Factors Influencing Integrated Project Delivery In Publicly Owned Construction Projects: An Information Modeling Perspective." proceeding of Fourth International Symposium on Infrastructure Engineering in Developing Countries Karachi, Pakistan, December 26- 28. 